ESCOLA POLITÉCNICA DA UNIVERSIDADE DE SÃO PAULO

MARIANA MINITTI LEITE PEREIRA

ESTUDO DE MISTURA ASFÁLTICA DE MÓDULO ELEVADO PARA CAMADAS DE BASE DE PAVIMENTO

São Paulo

2012 
MARIANA MINITTI LEITE PEREIRA

\section{ESTUDO DE MISTURA ASFÁLTICA DE MÓDULO ELEVADO PARA CAMADAS DE BASE DE PAVIMENTO}

Dissertação apresentada à Escola Politécnica da Universidade de São Paulo para obtenção do título de Mestre em Engenharia.

São Paulo

2012 
MARIANA MINITTI LEITE PEREIRA

\title{
ESTUDO DE MISTURA ASFÁLTICA DE MÓDULO ELEVADO PARA CAMADAS DE BASE DE PAVIMENTO
}

\author{
Dissertação apresentada à Escola Politécnica da \\ Universidade de São Paulo para obtenção do \\ título de Mestre em Engenharia. \\ Área de concentração: Engenharia de \\ Transportes. \\ Orientador (a): $\operatorname{Prof}{ }^{\mathrm{a}} \mathrm{Dr}^{\mathrm{a}}$ Liedi Légi Bariani \\ Bernucci
}


Este exemplar foi revisado e alterado em relação à versão original, sob responsabilidade única do autor e com a anuência de seu orientador.

São Paulo, 21 de dezembro de 2012.

Assinatura do autor

Assinatura do orientador

FICHA CATALOGRÁFICA

Pereira, Mariana Minitti Leite

Estudo de mistura asfáltica de módulo elevado para camadas de base de pavimento / M.M.L. Pereira. -- ed.rev. -- São Paulo, 2012.

$141 \mathrm{p}$.

Dissertação (Mestrado) - Escola Politécnica da Universidade de São Paulo. Departamento de Engenharia de Transportes.

1. Asfalto 2. Pavimentação 3. Base de pavimento I. Universidade de São Paulo. Escola Politécnica. Departamento de Engenharia de Transportes II. t. 
Dedico este trabalho à minha mãe Lúcia, ao meu pai Luiz, à minha irmã Marília e ao meu companheiro e amigo Eloy pelo carinho e apoio imensuráveis no desenvolvimento desta dissertação. 


\section{AGRADECIMENTOS}

Agradeço a todos que participaram e acompanharam o desenvolvimento deste trabalho. Àqueles que vivenciaram os momentos da construção desta obra, meu agradecimento especial. Com carinho agradeço:

- Primeiramente a Deus, pelos caminhos traçados em minha vida e por me dar o suporte, força e garra para cumprir mais uma etapa.

- Ao meu porto seguro, minha família, pela compreensão, força, estímulo e perseverança em apoiar as minhas escolhas. À minha mãe, Lúcia, agradeço pelas incontáveis orações e pela fé durante toda esta jornada. Ao meu pai, Luiz, pelo incentivo e apoio na educação de seus filhos. À minha irmã, Marília por sua presença e apoio sempre que precisei. Todas minhas conquistas são suas, obrigada por tudo!

- Ao meu amigo, companheiro de longa data e futuro marido, Eloy, pelos diversos momentos compartilhados ao longo deste trabalho, pelo apoio, pela calma, paciência e confiança depositada em mim ao longo de mais esta jornada.

- À família Minitti, Leite e Pereira por fazer de mim uma pessoa cada dia mais feliz.

- À minha professora e orientadora Liedi, agradeço por me tornar uma pessoa melhor e pela contribuição durante todo este trabalho. Obrigada por acreditar em mim, por manter-me calma e depositar em mim a sua confiança.

- À professora Kamilla pelas incontáveis conversas não agendadas e por contribuir com minha formação.

- Ao amigo Kendi pelo apoio em todos os ensaios de minha pesquisa.

- Ao amigo Assis pelo incentivo e por lançar a semente deste grande fruto que estou colhendo, minha dissertação.

- Ao amigo Cláudio Dias pelos estudos compartilhados ao longo desta pesquisa.

- À amiga Rosângela pelas conversas e pelos momentos de desabafos.

- À equipe do Laboratório - LTP USP pelo auxílio e pela contribuição em minha formação: Dio, Marcia, Igor, Edson, Robson, Erasmo e Claiton. 
- À equipe do Laboratório de Estradas da Escola de Engenharia de São Carlos: Thais Pamplona, Matheus Domingos e Professor Adalberto Faxina, pelo apoio nos ensaios.

- À equipe do laboratório do CPR - NovaDutra por estarem sempre dispostos a me ajudar e contribuir para a realização deste trabalho. Obrigada por toda a convivência e experiência trocadas. Agradeço em especial aos amigos Rubens, Cleto, Neto, Zé Carlos e Geraldo.

- À amiga Valéria Faria por depositar em mim sua confiança.

- Ao Grupo CCR por proporcionar-me momentos de estudo e aprendizado, agradeço pelo apoio durante esta pesquisa.

- Aos meus amigos por estarem presentes. 
"Uma longa viagem começa com um único passo."

Lao Tsé 


\section{RESUMO}

Esta pesquisa apresenta os resultados obtidos em análise laboratorial de misturas asfálticas de módulo elevado para aplicação em camada de base de pavimento. Historicamente, pode-se dizer que este tipo de mistura asfáltica em camadas de base resulta em melhor comportamento mecânico comparado com o de misturas asfálticas usinadas com CAP convencional. As misturas de módulo elevado apresentam vantagens em relação às convencionais com maior resistência à deformação permanente e maior vida de fadiga. Inicialmente, foram realizados ensaios laboratoriais de caracterização dos agregados e de três tipos de ligantes asfálticos: CAP A e CAP B, ambos ligantes duros com penetração entre $10 \mathrm{e}$ 20dmm, e um CAP convencional, CAP 30/45. Foram dosadas três misturas asfálticas, com uma graduação preestabelecida, e com os três ligantes asfálticos estudados, pelos métodos Marshall e SUPERPAVE. Os teores de projeto pelo método Marshall foram de 0,2 a 0,3\% superiores ao calculado pelo SUPERPAVE. Verificou-se $O$ atendimento das especificações francesas quanto ao volume de vazios das misturas compactadas com os CAPs A e B pelo compactador giratório francês $P C G$ ). Foram determinados os danos por umidade induzida, tendo sido verificado que a mistura com CAP B requer um melhorador de adesividade. Determinaram-se os afundamentos por deformação permanente, as resistências à tração, os módulos de resiliência em dois equipamentos diferentes (MTS e UTM), os módulos dinâmicos, e a vida de fadiga por compressão diametral e por flexão em viga de 4 pontos, das três misturas asfálticas estudadas. As deformações permanentes para as misturas com CAP A e CAP B são menores que o limite máximo estabelecido pelas diretrizes europeias, e inferiores ao valor obtido com 0 mistura com CAP 30/45. Os módulos de resiliência mostraram rigidez distinta entre as misturas do módulo elevado, sendo que a mistura com CAP $B$ é duas vezes mais rígida que a mistura com CAP A, que por sua vez é similar ao módulo com CAP 30/45. Obtiveram-se resultados similares de módulo de resiliência com equipamentos distintos. Os resultados dos ensaios de módulo dinâmico demonstraram proximidade de comportamento da mistura asfáltica com CAP A com misturas asfálticas com ligantes modificados; o módulo dinâmico da mistura com CAP B é similar àquele com CAP 30/45. Os resultados dos dois ensaios de fadiga 
empregados neste estudo demonstraram o melhor comportamento de misturas asfálticas compostas por ligantes duros e de módulo elevado, quando comparada com a mistura convencional. Todos resultados demonstram que há benefícios de misturas de módulo elevado como camada de base em relação às misturas com CAP convencional, e que esta é uma solução com grande potencial para estruturas de pavimento para tráfego pesado.

Palavras chaves: Misturas Asfálticas. Módulo elevado. Fadiga. 


\section{ABSTRACT}

This study presents the results obtained in laboratory analysis, about high modulus asphalt mixtures for use in base layer of pavement. Historically, it can be said that this type of mixture, when use in base layer, results in better mechanical behavior when compared with conventional asphalts. High modulus mixtures provide better behavior as it related layer's permanent deformation and a higher fatigue life. Initially, laboratory tests for characterizing aggregates and three types of asphalt binders were carried out: Binder A and Binder B, both hard binders with penetration between 10 and $20 \mathrm{dmm}$, and a conventional binder, namelly 30/45. Three types of asphalt mixtures were designed, with one predefined graduation and with those three asphalt binders, using Marshall and SUPERPAVE methods. Marshall's binder contents were from 0.2 to $0.3 \%$ higher than SUPERPAVE. The compacted asphalt mixtures were in compliance with French specifications in terms of air void content of Binder $A$ and Binder $B$ using the French gyratory compactor (PCG). Moisture-induced damage test was performed and it was verified that Binder $B$ needs an antistrip agent. Rutting, indirect tensile strength, resilient modulus in two different machines (MTS and UTM), dynamic modulus, and fatigue life by diametral compression and four point bending tests, were carried out with the three asphalt mixtures studied. The results of rutting for mixtures with Binders $A$ and $B$ were lower than the maximum limit of European specifications, and lower than the result with Binder 30/45. Resilient modulus showed different stiffness between the high modulus mixtures, where the asphalt mixture with Binder $B$ was twice stiffer than the mixture with Binder $A$, which in turn is similar to the resilient modulus of the asphalt mixtures with Binder 30/45. Analogous results were observed in different resilient modulus machines. Dynamic modulus results showed similar behavior between the asphalt mixture with Binder $A$ and asphalt mixture with modified binders; dynamic modulus of the asphalt mixture with Binder $B$ was similar to the asphalt mixture with Binder 30/45. Results in the two fatigue tests were better for the asphalt mixtures with hard binders and high modulus in comparison with the conventional asphalt mixture. All the results demonstrate benefits of high modulus mixtures as base layer in pavements in comparison with 
asphalt mixtures with conventional binders, and the solution has a great potential in pavement structures for heavy traffic.

Keywords: Asphalt Mixtures. High Modulus. Fatigue . 


\section{SUMÁRIO}

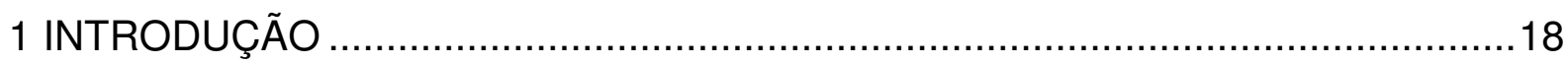

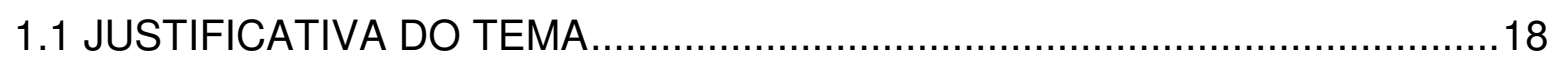

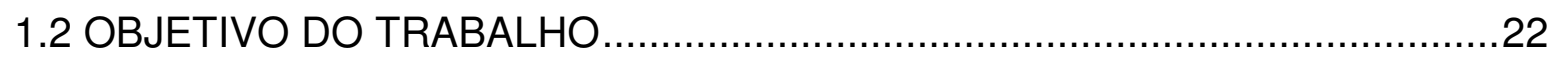

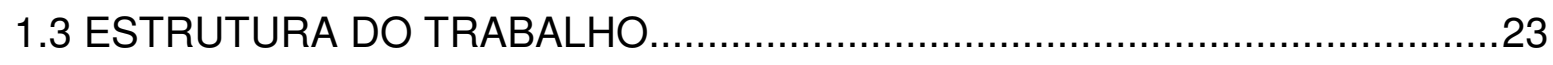

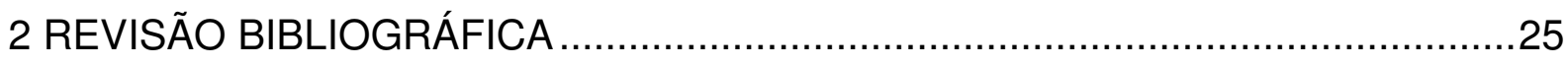

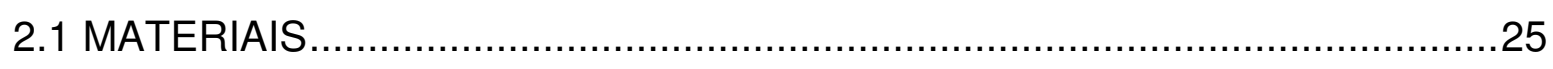

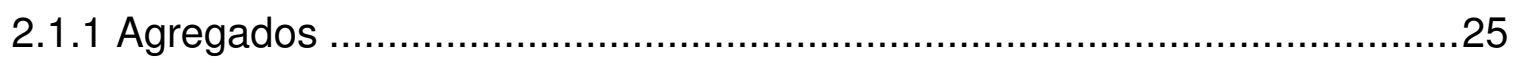

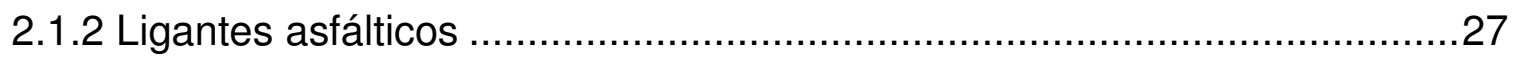

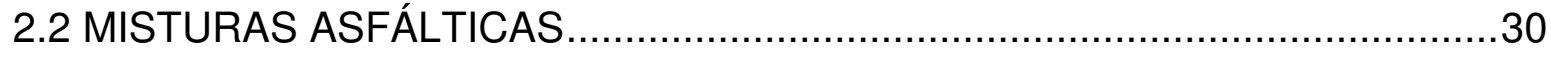

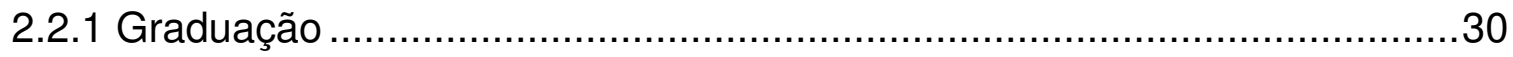

2.2.2 Avaliação dos agregados combinados .................................................

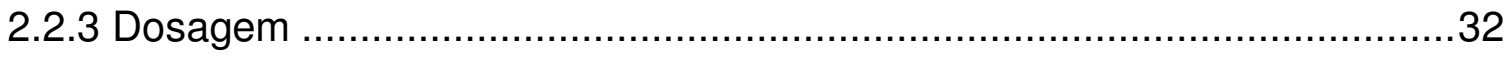

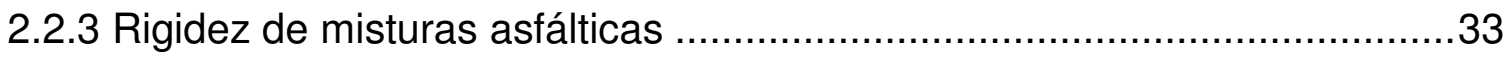

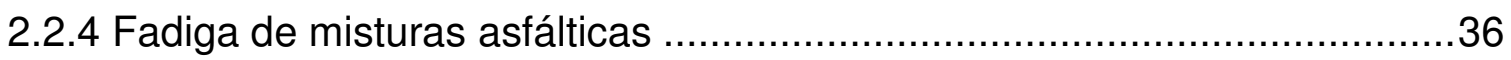

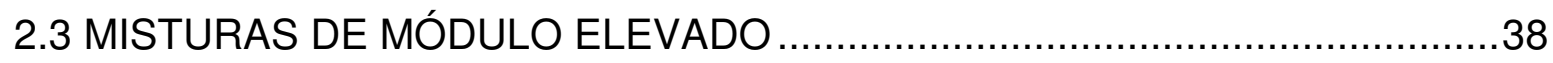

2.3.1 Procedimentos para projeto de misturas asfálticas pelo método francês .. 45

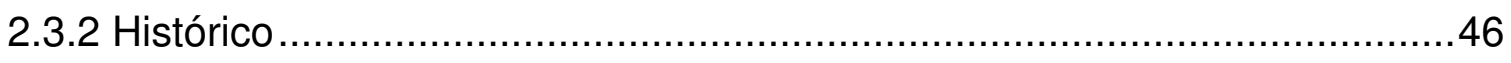

2.3.3 Experiências anteriores com EME ................................................... 49

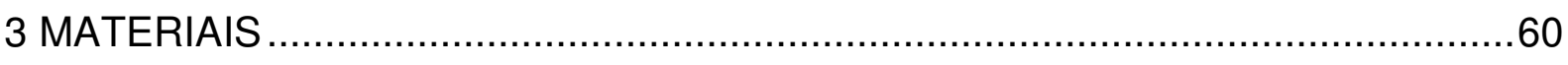

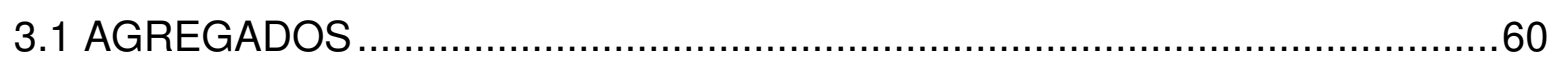

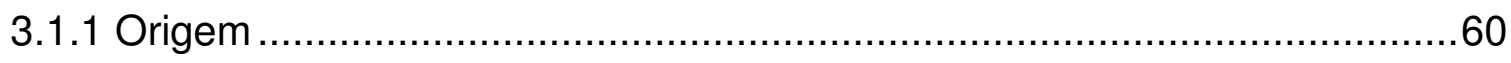

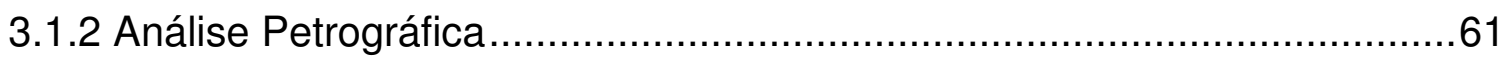

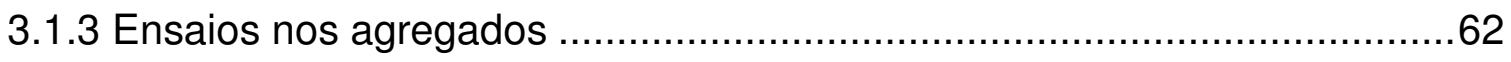

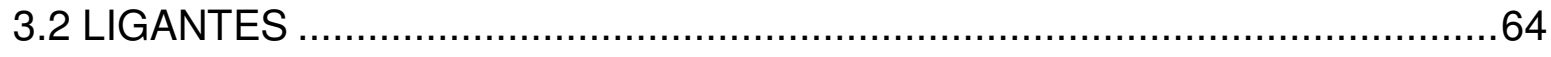


4.1 GRANULOMETRIA

4.2 VERIFICAÇÃO DOS AGREGADOS COMBINADOS PELO MÉTODO BAILEY

4.3 DOSAGENS

4.3.1 Dosagem Marshall

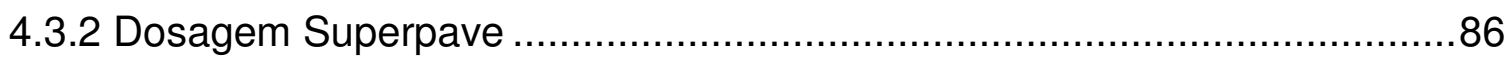

4.3.3 Compactação no compactador giratório francês ................................ 88

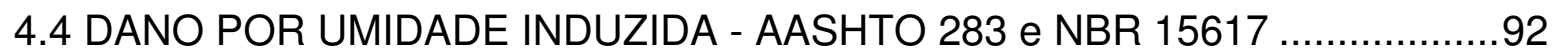

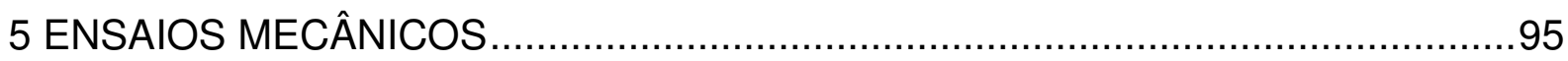

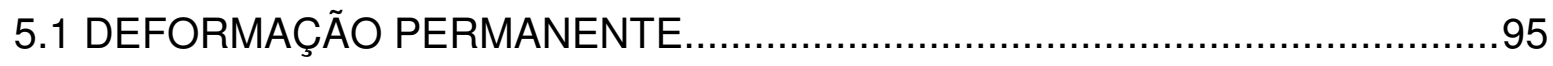

5.2 RESISTÊNCIA À TRAÇÃO POR COMPRESSÃO DIAMETRAL .....................98

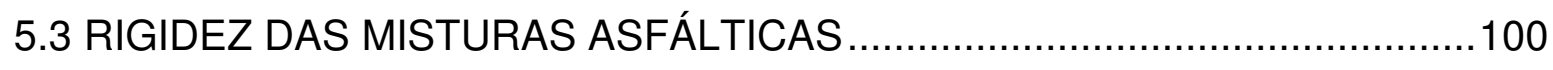

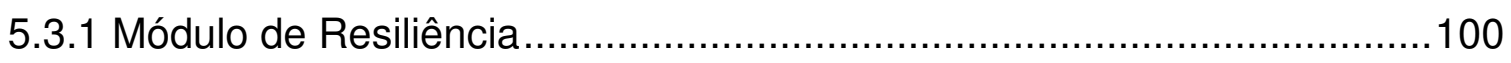

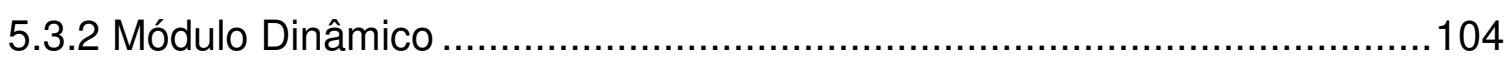

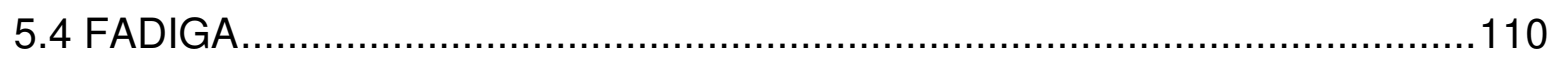

5.4.1 Fadiga por tração em ensaio de compressão diametral ......................111

5.4.2 Fadiga por flexão em ensaio de viga com 4 pontos..............................114

5.4.3 Análise comparativa entre os métodos de fadiga .............................117

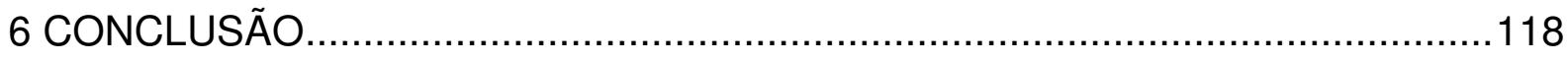

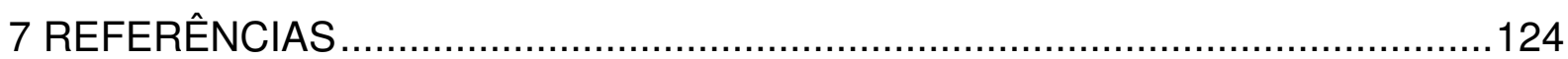

APÊNDICE A - Gráfico resultante do ensaio reológico dos ligantes A e B na condição virgem

APÊNDICE B - Dosagem Marshall ..................................................... 134

APÊNDICE C - MóduloDinâmico para cada temperatura de ensaio ..................137

APÊNDICE D - Sequência de ensaios utilizados nesta pesquisa e laboratórios

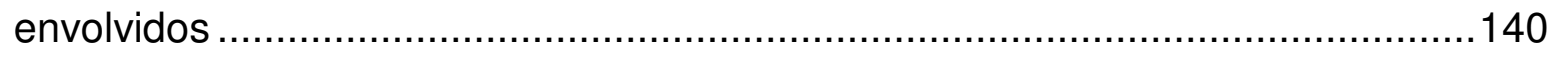

ANEXO A - Fatores que afetam a rigidez e vida de fadiga de misturas ..............141 


\section{LISTA DE FIGURAS}

Figura 1 - Curvas granulométricas de EME empregadas em estudos brasileiros ....31

Figura 2 - Curvas mestras - resultado de ensaio de módulo complexo de misturas asfálticas, Corté (2001)

Figura 3 - Comparação entre resultados de ensaio de módulo de resiliência e módulo dinâmico ( Hu et al., 2008).

Figura 4 - Representação de tensões no centro da amostra durante ensaio de tensão controlada (LOUREIRO, 2003)...

Figura 5 - Relação de tensão e deformação para ensaio de fadiga em misturas asfálticas (LOUREIRO, 2003)

Figura 6 - Seção esquemática estrutura de pavimento perpétuo (adaptado de Corté, 2001)

Figura 7- Resultados do ensaio de fadiga por compressão diametral do estudo de Magalhães (2004)

Figura 8 - Resultados do ensaio de fadiga por compressão diametral estudado por Freitas (2007)

Figura 9 - Resultado do ensaio de fadiga por compressão diametral do estudo de Rohde (2007)

Figura 10 - Localização de Jambeiro no Estado de São Paulo

Figura 11 - Imagem fotográfica da composição mineralógica da rocha de origem dos agregados

Figura 12 - Equipamento para o ensaio de penetração em amostra do ligante instalado no CPR-NovaDutra

Figura 13 - Equipamento para o ensaio de viscosidade no Viscosímetro Brookfield instalado no CPR-NvaDutra

Figura 14 - Sequência de ensaio de Ponto de Amolecimento - anel e bola, CPRNovaDutra

Figura 15 - Determinação da massa do picnômetro preenchido metade com água e metade com asfalto a $25^{\circ} \mathrm{C}$ 
Figura 17 - Sequência de ensaio de envelhecimento a curto prazo RTFOT - EESCUSP

Figura 18 - Parâmetro de PG para ligantes virgens - CAP A, CAP B e CAP 30/4573

Figura 19 - Valores de $\mathrm{G}^{*}$ dos ligantes asfálticos duros (CAP A e CAP B) .74

Figura 20 - Ângulos de fase (d) dos ligantes asfálticos duros (CAP A e CAP B) ......74

Figura 21 - Gráfico de percentual de recuperação dos ligantes asfálticos .................76

Figura 22 - Gráfico de compliância não recuperável dos ligantes asfálticos ..............77

Figura 23 - Diferença percentual de compliâncias (a baixa e alta tensão) ……….....78

Figura 24 - Imagem dos agregados utilizados na pesquisa ....................................80

Figura 25 - Curva granulométrica empregada na pesquisa......................................81

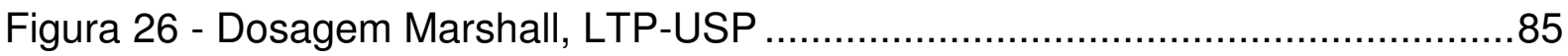

Figura 27 - Procedimento de dosagem Superpave, CPR-NovaDutra ......................87

Figura 28 - Gráficos com resultados da dosagem Superpave para as misturas

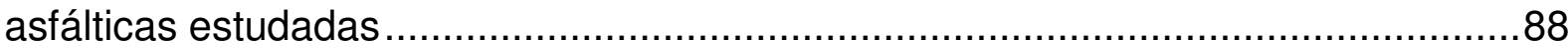

Figura 29 - Etapas do processo de compactação no compactador giratório francês PCG

Figura 30 - Gráfico da compactação da mistura de módulo elevado com CAP A PCG

Figura 31 - Gráfico da compactação da mistura de módulo elevado com CAP B PCG

Figura 32 - Ensaio de dano por umidade induzida , LTP-USP

Figura 33 - Ensaio de deformação permanente, LTP-USP

Figura 34 - Deformação permanente das misturas compostas com: CAP A, CAP B e CAP $30 / 45$

Figura 35 - Equipamento para ensaio de RT (prensa), CPR-NovaDutra ………......99

Figura 36 - Determinação do módulo de resiliência 100

Figura 37 - Representação gráfica do resultado de ensaio de MR nos equipamentos: MTS e UTM 102

Figura 38 - Análise de um pulso do ensaio de MR para misturas elaboradas com CAP A, CAP B e CAP 30/45. 
Figura 39 - Equipamento e instrumentação do ensaio de módulo dinâmico

Figura 40 - Confecção das placas para extração de corpos-de-prova para ensaio de módulo dinâmico

Figura 41 - Dados de ensaio de módulo dinâmico e curva mestra para a mistura asfáltica com o CAP A

Figura 42 - Dados de ensaio de módulo dinâmico e curva mestra para a mistura asfáltica com o CAP B.

Figura 43 - Dados de ensaio de módulo dinâmico e curva mestra para a mistura asfáltica com o CAP 30/45

Figura 44 - Curvas mestras das três misturas asfálticas da pesquisa ( $T$ de referência $\left.21,1^{\circ} \mathrm{C}\right)$

Figura 45 - Ensaio de fadiga de compressão diametral, LTP-USP

Figura 46 - Resultados do ensaio de fadiga por compressão diametral - tensão controlada.

Figura 47 - Vigota para ensaio de fadiga por flexão de 4 pontos

Figura 48 - Equipamento e instrumentação para ensaio de fadiga por flexão de 4 pontos

Figura 49 - Resultados do ensaio de fadiga por flexão em viga de 4 pontos deformação controlada.

Figura 50 - Vigota de mistura asfáltica de módulo elevado após ensaio de fadiga por flexão de 4 pontos 


\section{LISTA DE TABELAS}

Tabela 1 - Diferenças entre os ensaios de módulo de resiliência e módulo dinâmico

Tabela 2 - Limites de módulo de riqueza para misturas de módulo elevado (NF 98$140,1999)$

Tabela 3- Nível 1: compactação da mistura (adaptado DEMORME et al., 2007)......43

Tabela 4 - Nível 2: deformação permanente (adaptado DELORME et al., 2007) .....43

Tabela 5 - Nível 3: módulos complexo da mistura (adaptado DELORME et al., 2007)

Tabela 6 - Nível 4: fadiga a flexão dois pontos (adaptado DELORME et al., 2007) .43

Tabela 7 - Espessuras de utilização para misturas de módulo elevado ( NF-98 140,1999)

Tabela 8 - Evolução de asfaltos duros na França (PIARC, 1998) ..........................46

Tabela 9 - Histórico francês de emprego das misturas de módulo elevado.

Tabela 10 - Valores de características mecânicas de misturas asfálticas estudadas por Magalhães (2004)

Tabela 11 - Características dos ligantes estudados por Freitas (2007).

Tabela 12 - Valores de características mecânicas de misturas asfálticas estudadas por Freitas (2007).

Tabela 13 - Resultados do estudo laboratorial elaborado por Rohde (2007) ...........56

Tabela 14 - Resultados do estudo experimental elaborado por Rohde (2007)........57

Tabela 15 - Resultado do ensaio de equivalente de areia ...................................63

Tabela 16 - Caracterização dos ligantes utilizados na pesquisa .............................72

Tabela 17 - Classificação do ligante asfáltico por nível de tráfego variando a temperatura.....

Tabela 18 - Composição granulométrica da mistura em estudo 80

Tabela 19 - Limites para parâmetros de misturas de agregados combinados pelo Método Bailey. 
Tabela 20 - Peneiras de controle encontradas para a mistura dos agregados combinados para análise pelo Método Bailey.....

Tabela 21 - Valores encontrados para a análise da mistura de agregados pelo Método Bailey.....

Tabela 22 - Resumo dos resultados obtidos com a dosagem Marshall para as misturas asfálticas estudadas

Tabela 23 - Resultado da dosagem Superpave paras misturas asfálticas estudadas

Tabela 24 - Resultado da compactação das misturas de módulo elevado estudadas na PCG .90

Tabela 25 - Resultado de dano por umidade induzida das misturas de módulo elevado

Tabela 26 - Resultados de ensaio de deformação permanente para 1.000, $10.000 \mathrm{e}$ 30.000 ciclos

Tabela 27 - Equações obtidas das curvas de regressão dos ensaios de deformação permanente .98

Tabela 28 - Resultados do ensaio de RT para as misturas estudadas .99

Tabela 29 - Resultados de ensaio de MR 102

Tabela 30 - Características dos ensaios de fadiga empregados neste trabalho .... 


\subsection{JUSTIFICATIVA DO TEMA}

O Brasil possui mais de 219 mil $\mathrm{km}$ de rodovias pavimentadas ao longo de seu território, segundo DNIT, Departamento Nacional de Infraestrutura de Transportes ${ }^{1}$. Durante sua história, o país fez do sistema de transporte rodoviário o seu principal meio de ligação comercial entre regiões. Diante deste cenário a importância das rodovias foi aumentando com o tempo, sendo hoje o principal meio de transporte de passageiros e de bens, respondendo por cerca de $58 \%$ do total de carga transportada no Brasil.

Nesse contexto, o pavimento passa a ser uma chave que quando acionada tende a acelerar a economia do país. A utilização dos materiais e métodos de dimensionamento e métodos construtivos empregados para melhoria das condições do pavimento rodoviário tem sido muito estudados no país. Há uma busca pela inovação de nossas técnicas de pavimentação, destacadamente dos materiais a serem empregados, sempre com o objetivo de garantir maior durabilidade à estrutura de pavimento, maior benefício/custo, tanto no quesito prazo, quanto no quesito custo e segurança do usuário. O pavimento, em geral, responde por um dos maiores custos ao longo da construção e o maior custo durante a manutenção de uma rodovia, e por este motivo sua estrutura, execução e técnica de manutenção vêm sendo muito estudadas ao longo dos últimos anos em diversos países.

A evolução econômica do Brasil na última década foi intensa, de maneira que revelou necessidades de investimentos em infraestrutura dos transportes. É notória a preocupação com o aumento significativo de caminhões na frota rodoviária

\footnotetext{
${ }^{1}$ Os dados referentes às rodovias brasileiras foram consultados no site do Departamento Nacional de Infraestrutura de Transportes, DNIT, www.dnit.gov.br , acessado em: 08/09/2012.
} 
brasileira: eram 16\% em 1999, este número dobrou atingindo a média de $32 \%$ em dez anos (CNT, 2011).

Um exemplo de rodovia com intenso volume de tráfego e com grande parte deste tráfego composta por caminhões é a Rodovia Presidente Dutra, construída em 1950, ligando duas regiões metropolitanas muito importantes para país, Rio de Janeiro e São Paulo, com 402 km de extensão. A Rodovia Presidente Dutra, desde sua inauguração, tem apresentado alto volume de tráfego, sendo que o número $\mathrm{N}$ de repetição de carga do eixo padrão de $80 \mathrm{kN}$ alcança em média valores maiores que $10^{8}$. Parcela significativa do total da frota é composta por veículos de carga que respondem em média por $36 \%$ do tráfego da Dutra; há casos em que a carga por eixo supera os limites permitidos pela Resolução 258 do CONTRAN, Conselho Nacional de Trânsito (2007).

No Brasil, tem-se estudado, nos últimos anos, soluções alternativas para o tráfego pesado, uma vez que a estrutura de pavimento não tem atingido o tempo de vida útil projetado em grande parte de nossas rodovias, sendo necessárias manutenções com maior frequência do que a definida em projeto. Dentre estas alternativas, podem-se citar: o pavimento de concreto de cimento Portland; a reciclagem de pavimento existente com novos revestimentos asfálticos e o uso de camada asfáltica de base com elevada resistência e baixa deformabilidade, constituída de mistura asfáltica de módulo elevado.

Nas últimas décadas, empregou-se, no Brasil, a técnica de pavimento de concreto de cimento Portland em pátios de aeronaves e pátios portuários e terminais de ônibus e terminais industriais. Alguns dos problemas a ser superado na utilização deste material são as fissuras nas placas decorrentes de projetos inadequados, concreto fora do traço, corte de juntas em momento inapropriado e em profundidade inadequada e cura incorreta, além de outros. Para que este tipo de problema seja evitado é necessário que se tenha maior atenção no momento de seleção do tipo de pavimento de concreto que será utilizado, cuidado na elaboração de projeto principalmente em sua especificação, na correta seleção de insumos, nas misturas desses insumos com qualidade e na boa execução e cautelosa fiscalização em campo. 
A reciclagem de pavimento é uma técnica que tem sido empregada com maior constância e tem-se mostrado uma boa opção para recuperação de camadas de base de pavimento deterioradas e com insuficiência estrutural, uma vez que equipamentos cada vez mais evoluídos estão sendo colocados no mercado. Duas das principais vantagens que podem ser consideradas sobre o emprego dessa técnica são: o benefício ambiental, visto que grande parte do material, ou mesmo todo o material pode ser reaproveitado e a redução das distâncias de transportes, principalmente com as técnicas in situ, ou com recicladoras móveis.

Módulo elevado é a designação de uma mistura asfáltica que apresenta alta resistência à deformação permanente e uma maior vida de fadiga. Uma mistura asfaltica de módulo elevado é composta por agregados que compõem uma curva granulométrica bem distribuída e contínua. A mistura possui baixo volume de vazios e alto teor de ligante, sendo o ligante empregado para este tipo de mistura um asfalto com baixa penetração e alta viscosidade. Esta combinação pode resultar em estruturas com bom comportamento mecânico, pouca permeabilidade e alta durabilidade. Módulo elevado utilizado como camada de base para estruturas de pavimento submetida a um alto volume de tráfego é o tema de estudo abordado nessa pesquisa.

O módulo elevado teve sua história iniciada na França e posteriormente disseminou pelos países da Europa. Esse tipo de mistura foi testada em vários países, ao longo dos anos; a mistura foi apontada como uma técnica precursora para o bom comportamento de uma estrutura de pavimento flexível com possibilidade de aumentar sua vida útil e reduzir suas deformações.

O EME, Enrobé à Module Élevé, como denominado em muitos estudos e no presente estudo denominado módulo elevado, leva esta designação por apresentar módulo complexo à $15^{\circ} \mathrm{C}$, na frequência de $10 \mathrm{~Hz}$, superior a $14.000 \mathrm{MPa}$, conforme normatização francesa NF P 98-140 (AFNOR, 1999). O módulo complexo passou a ser um ensaio mais representativo para caracterização das misturas asfálticas, uma vez que possibilita uma varredura de temperatura e frequências, possibilitando a construção de uma curva mestra por meio da combinação destas duas variáveis 
pelo princípio de superposição tempo-temperatura, descrevendo melhor a característica viscoelástica da mistura.

No Brasil o procedimento para extração de valores de módulo é descrito para módulo de resiliência e por este motivo será abordado ao longo desse trabalho valores de módulo de resiliência e não módulo complexo, como determinado na norma francesa. Segundo Bernucci et al.(2008), valores de módulo de resiliência referenciais para misturas de módulo elevado destinados a camadas de base variam de 12.000MPa a 20.000MPa, podendo ser caracterizado como um pavimento semirrígido no quesito deformabilidade.

A deformação permanente também é um quesito de importância para estruturas de base com módulo elevado, uma vez que o ligante duro, que fornece valores elevados de módulos, pode reduzir significativamente o percentual de deformação de uma estrutura, fazendo-a resistir aos esforços de compressão no topo da camada. A deformação de uma estrutura formada por uma camada de base de módulo elevado pode ser três vezes menor do que em uma mistura convencional.

A fadiga, ponto de suma importância nesta mistura, também será estudada nesta pesquisa. Uma estrutura de módulo levado deve apresentar uma maior vida de fadiga ao pavimento uma vez que se trata de uma estrutura mais rígida capaz de suportar por mais tempo os esforços aos quais será submetida.

Ao longo desse trabalho serão apresentados valores de módulo de resiliência obtidos em trabalhos nacionais, bem como o estudo de misturas de módulo elevado e sua aplicação no Brasil. Serão citados trabalhos realizados na Universidade Federal do Rio de Janeiro (UFRJ), desenvolvido por Magalhães (2004); na Universidade Federal do Rio Grande do Sul (UFRGS), desenvolvido por Rohde (2007) e na Escola Politécnica da Universidade de São Paulo (Poli-USP), desenvolvido por Villela (2012).

Este trabalho contempla dados de três misturas asfálticas, misturas compostas por dois ligantes duros A e $B$ e ligante convencional CAP 30/45. O estudo dos materiais foi realizado por meio de ensaios de caracterização e ensaios reológicos dos ligantes e ensaios de caracterização dos agregados. O estudo das misturas asfálticas adotadas compreendeu: dois tipos de dosagens para misturas asfálticas 
(Marshall e Superpave); duas diferentes determinações de módulo: ensaios de módulo de resiliência e ensaios de módulo dinâmico e, também ,dois tipos de ensaio de fadiga: fadiga por compressão diametral a tensão controlada e fadiga por flexão de 4 pontos a deformação controlada, com intuito de melhor entender o comportamentos das misturas asfálticas empregadas.

Optou-se por realizar estes ensaios com as misturas asfálticas estudadas como forma de contribuição para o estudo da aplicablidade de misturas de módulo elevado como camada de base em rodovias de alto volume de tráfego no país.

No Brasil, não há referências normativas para misturas de módulo elevado, sendo assim este trabalho contempla o levantamento e comparação entre resultados de estudos já realizados no país e no exterior.

A França, precursora desta técnica e pioneira na especificação técnica para este tipo de mistura é referência de especificação técnica para misturas de módulo elevado; utilizou-se de suas especificações para adequar, em alguns casos, ensaios realizados no Brasil para análise do comportamento das misturas de módulo elevado estudadas.

\subsection{OBJETIVO DO TRABALHO}

O objetivo desta pesquisa é o estudo dos materiais (agregado e ligante), análise da dosagem e do comportamento mecânico de misturas asfálticas de módulo elevado para constituírem camadas de base de estruturas de pavimentos para tráfego pesado.

Foram estudadas as características desejadas do agregado para atingir um bom desempenho estrutural na camada de módulo elevado, qual a graduação recomendada para aplicabilidade desta técnica construtiva e quais as características do ligante para este tipo de mistura asfáltica. 
A pesquisa visa contribuir para a seleção e adequação dos materiais nacionais na aplicação dessas estruturas em rodovias brasileiras com alto volume de tráfego, um cenário muito comum e com perspectiva de crescimento no país.

A pesquisa contempla também a comparação de características mecânicas como módulo de resiliência, módulo dinâmico, deformação permanente e vida de fadiga de misturas de módulo elevado com uma mistura convencional com intenção de demonstrar o melhor comportamento da mistura de módulo elevado perante à mistura convencional.

O resultado esperado neste trabalho é fornecer informações sobre o estudo e aplicação de estruturas com módulo elevado para camadas de base nas rodovias brasileiras.

\subsection{ESTRUTURA DO TRABALHO}

Este trabalho está organizado em seis capítulos.

O capítulo 1 é um capítulo introdutório que fornece uma breve contextualização do trabalho, além da justificativa para a escolha do tema em estudo, seus objetivos e sua organização.

O capítulo 2 aborda as características dos materiais para este tipo de mistura seja o agregado ou o ligante, este último peça chave em misturas de módulo elevado, uma vez que o mesmo deve apresentar baixa penetração e alta viscosidade. O capítulo faz uma abordagem sobre graduação utilizada em trabalhos de módulo elevado no país e mistura de agregados combinados. Aborda também uma introdução sobre rigidez de misturas asfálticas e um panorama sobre fadida. Há uma exposição quanto ao histórico da aplicação de estruturas de módulo elevado no exterior e no Brasil, bem como sua aplicação em segmentos de pista teste e trechos experimentais. Neste capítulo ainda são retratadas a importância da deformação 
permanente e o ensaio de fadiga para estrutura de módulo elevado, uma vez que o comportamento mecânico dessa mistura é seu principal diferencial quando comparado com uma mistura convencional.

O capítulo 3 aborda a apresentação e caracterização dos materiais empregados na pesquisa, assim como os procedimentos de ensaio. Nesse capítulo pode-se notar a importância da seleção e da caracterização do material para o emprego em uma mistura asfáltica. O capítulo contempla parâmetros mínimos de aceitabilidade para alguns resultados de ensaios nos materiais para utilização em mistura de módulo elevado.

O capítulo 4 aborda a granulometria empregada na pesquisa, a verificação dos agregados estudados pelo método Bailey, os procedimentos e resultados das dosagens realizadas ao longo do trabalho: dosagem Marshall e Superpave. Este capítulo contempla, também, o procedimento de ensaio e o resultado do ensaio de compactação no compactador giratório francês. E por fim, procedimento e resultado da avaliação de cada mistura ao dano por umidade induzida.

O capítulo 5 traz descrição, procedimentos e resultados de ensaios mecânicos empregados na pesquisa para análise das misturas asfálticas de módulo elevado, bem como sua comparação com a mistura convencional.

O capítulo 6 aborda a conclusão do estudo e um panorama dos resultados obtidos, sendo expostos os pontos fundamentais e relevantes da pesquisa. Neste capítulo final são propostas possíveis pesquisas a serem desenvolvidas no Brasil, uma vez que esta mistura tem muito a contribuir para a pavimentação nacional. 


\subsection{MATERIAIS}

\subsubsection{Agregados}

Agregado é todo material mineral duro e inerte, fragmentado, usado em misturas. Os agregados são materiais granulares que misturados a um aglomerante do tipo asfáltico constitui um material passível de utilização para fins de pavimentação. Os agregados são, portanto, componentes fundamentais na composição de uma mistura asfáltica, uma vez que compreendem cerca de 95\% da constituição de uma mistura. $\mathrm{O}$ agregado mineral influencia diretamente as propriedades volumétricas e, como consequência, as propriedades de rigidez, resistência ao cisalhamento e a vida de fadiga de uma mistura asfáltica. No Brasil, a obtenção dos agregados é realizada nas pedreiras, sendo que a escolha da pedreira que irá fornecer o material britado para a execução de uma obra está atrelada à sua distância do segmento que será executado, à logística é um fator crucial na escolha da pedreira.

Segundo o DNER (1996) os agregados são classificados quanto a sua natureza, tamanho e graduação. Para misturas asfálticas, a natureza física dos agregados é de extrema importância. Dentre estas características físicas a norma brasileira orienta que informações sejam obtidas previamente aos ensaios de misturas asfálticas, tais como: forma e textura; porosidade e absorção; ausência de materiais deletérios existentes na superfície do agregado e afinidade com o asfalto. A característica mecânica avaliada nos agregados é a sua resistência à abrasão.

Os agregados são obtidos através do desmonte de uma rocha sã através de explosivos e com a utilização de britadores de modo que a dimensão do agregado atenda parâmetros de utilização para pavimentação. É interessante que a produção do agregado seja norteada para formatos cúbicos, pois estes formatos resultam em 
um melhor desempenho no conjunto agregado/ligante asfáltico. Ultimamente, em virtude da preocupação ambiental, estão sendo desenvolvidos estudos com material alternativo que possam ser utilizados como agregado, como as escórias provenientes de processos siderúrgicos. Ao longo desta pesquisa serão citados trabalhos brasileiros com uso de escória que resultaram em misturas asfálticas de módulo de resiliência elevado.

Os agregados podem influenciar no comportamento de campo de uma mistura, pois defeitos de pavimento como segregação e deformação na trilha de roda podem ser provenientes da má escolha do agregado, que resultou em um esqueleto pétreo pouco resistente. Com intuito de reduzir estas ocorrências, as normas brasileiras indicam alguns ensaios que podem auxiliar na escolha dos agregados para um bom desempenho do pavimento, dentre eles estão: abrasão Los Angeles e equivalente de areia. No ensaio de abrasão Los Angeles espera-se que o material seja capaz de resistir ao atrito e impacto causado pelo contato. Tal resistência deve obedecer ao limite máximo de desgaste permitido que é de $40 \%$. O resultado de equivalente de areia deve ser no mínimo $55 \%$ para misturas asfálticas.

A escolha do agregado se adequa à sua aplicação, no entanto, a avaliação do material e suas propriedades se dão através da análise de: seu tamanho e graduação, limpeza, rigidez, textura superficial, forma das partículas, absorção e afinidade pelo asfalto.

O arranjo das misturas depende não somente das características individuais de cada grão, mas também da composição dos grãos na mistura. As partículas cúbicas fornecem maior estabilidade mecânica à estrutura, uma vez que propiciam melhor intertravamento entre grãos. As partículas com textura rugosa aumentam a resistência, uma vez que necessitam de mais ligante para superar a resistência ao cisalhamento e permitir a trabalhabilidade. A resistência dos agregados interfere na compactação uma vez que agregados frágeis se degradam mais quando submetidos a impacto, fornecendo instabilidade à mistura.

Algumas propriedades dos agregados dependem de suas características naturais ou mesmo condições de fabricação como:

- Porosidade: possui influência na massa específica, na absorção de água, na resistência, na dureza, no módulo de elasticidade e na sanidade; 
- Tamanho, forma e textura das partículas: são influenciadas pela ação de intempéries e sua condição de fabricação;

- Composição mineralógica: influência na resistência, na dureza, no módulo de elasticidade e nas substâncias deletérias presentes.

No caso de misturas de módulo elevado os agregados devem possuir diâmetro máximo de $10 \mathrm{~mm}, 14 \mathrm{~mm}$ ou $20 \mathrm{~mm}$. A escolha dos agregados deve ser feita de maneira que atendam a uma faixa de trabalho a ser empregada. Os agregados devem atender a todos os requisitos normativos como em qualquer outra mistura, pois a escolha do agregado está atrelada à obtenção de uma boa estrutura pétrea que em conjunto com o ligante asfáltico remete há uma mistura asfáltica com um bom comportamento em campo.

\subsubsection{Ligantes asfálticos}

O asfalto tem a propriedade de tornar-se resistente e estável, sendo usado para união de materiais utilizados para pavimentação e pode ser considerado um dos mais versáteis produtos da natureza (INSTITUTO DO ASFALTO, 2002). Oriundo da destilação do petróleo, o resíduo asfáltico, quando atende às características de penetração e viscosidade, é denominado CAP, cimento asfáltico de petróleo, um material durável, flexível e altamente resistente à ação de ácidos, sais e álcalis.

Inicialmente, os asfaltos eram encontrados na natureza ora em estágio mole em camadas geológicas, os quais poderiam ser utilizados sem tratamento específico, os denominados asfaltos naturais; ou ainda em rochas friáveis. $O$ asfalto pode ser obtido ainda por meio do processamento do petróleo sendo atualmente o principal meio de obtenção deste produto para fins de pavimentação. O estudo das características do asfalto iniciou após o século 20, quando os asfaltos passaram a ser utilizados em estradas. 
Para a engenharia rodoviária, o asfalto é uma das matérias primas mais importantes devido às suas características de aderência, impermeabilidade e durabilidade, além de ser considerado um material betuminoso e termoplástico.

Os ligantes são classificados pela sua consistência. Os asfaltos duros caracterizamse por apresentar uma baixa penetração, de $10 \mathrm{dmm}$ a $20 \mathrm{dmm}$ a $25^{\circ} \mathrm{C}$, e uma alta viscosidade. O tipo de ligante a ser empregado em uma mistura é de extrema importância uma vez que influenciará a resistência ao afundamento por trilha de roda. Está comprovado que ligantes de alta consistência apresentam resultados de afundamentos por deformação permanente inferiores aos do ligante convencional, contribuindo assim para minimizar os efeitos da trilha de roda em rodovias de alto volume de tráfego.

A opção por fabricação de ligantes com baixa penetração surgiu da necessidade de se ter misturas asfálticas mais duráveis. As propriedades mecânicas dos asfaltos duros são muito dependentes do processo de manufatura, pois a composição química influencia a estrutura coloidal das partículas que o compõe. A dureza do CAP utilizado em mistura de módulo elevado permite baixa deformabilidade à mistura em comparação com concretos asfálticos normalmente empregados como camada de base de pavimentos. Bases asfálticas de módulo elevado promovem uma redução de esforços no subleito devido à sua elevada rigidez permitindo a utilização de menores espessuras no dimensionamento de camada de base.

Ainda tem-se como alternativa para asfaltos duros, os asfaltos modificados por adição de produtos tais como: ácido polifosfórico, asfaltita ou polímeros. O modificador está muito relacionado a questões de desempenho do pavimento quando submetido à variação de temperatura (CORTÉ, 2001). Na China obtiveram resultados positivos com estudos que contemplavam a adição de modificador em asfaltos, baseado na metodologia francesa (YANG et al., 2006).

Asfaltos modificados por polímero passaram a ser utilizados no Brasil a partir da década de 1990, como uma solução para misturas asfálticas para revestimento. Esta alternativa tinha como finalidade a aplicação em vias de tráfego pesado com 0 objetivo de garantir melhores condições mecânicas à estrutura do pavimento, além de proporcionar maior durabilidade para o pavimento, minimizando, assim, os períodos de intervenção. 
Diante da realidade brasileira, com tráfego crescente e com o aumento expressivo do número de veículos comerciais nas rodovias, os pavimentos passaram a apresentar defeitos precocemente como trincamentos por fadiga e ATR (afundamento em trilha de rodas). Assim, o uso de asfaltos modificados por polímeros passou a ser difundido na história do pavimento brasileiro e hoje em dia já não é mais uma novidade e sim um produto utilizado em larga escala (BERNUCCI, 2000).

O EVA tem como maior vantagem sua resistência à flexão e estabilidade térmica, asfaltos modificados com EVA apresentam alta viscosidade, podendo apresentar valores elevados de módulo de resiliência, conforme estudos já realizados para misturas de módulo elevado.

O asfalto modificado com ácido polifosfórico (PPA - polyphosphoric acid) pode também apresentar valores de módulo de resiliência elevado para uma mistura, uma vez que a adição deste modificador no asfalto resulta em um aumento no ponto de amolecimento, na viscosidade, na resistência ao envelhecimento e diminuição da penetração (ROHDE, 2007). No trabalho de Rohde (2007) foi demonstrado que a utilização deste material juntamente com a cal hidratada como fíler, na composição de uma mistura, pode minimizar os efeitos deste modificador, principalmente em se tratando de misturas de módulo elevado.

Asfaltos modificados com RASF (resíduo de desasfaltação a propano - resíduo asfáltico de petróleo), quando utilizados em misturas asfálticas, podem elevar em até três vezes o módulo de resiliência, tendo como base de comparação uma mistura convencional (MAGALHÃES, 2004).

Outra característica importante do ligante asfáltico é o seu grau de desempenho PG (performance grade) segundo a especificação Superpave. O PG indica em quais temperaturas do pavimento (máxima e mínima) o ligante asfáltico deve atender a determinados requisitos da especificação Superpave. O PG é composto por dois números, onde o primeiro corresponde à média das máximas temperaturas observadas no pavimento durante os 7 dias consecutivos mais quentes do ano, sendo o grau a alta temperatura; o segundo número corresponde à mínima temperatura que atua no pavimento no dia mais frio do ano, sendo o grau a baixa temperatura. $O$ intervalo de temperatura entre as classe é de $6^{\circ} \mathrm{C}$. Estudos 
apresentados nesta pesquisa demonstram que valores de PG para o grau a alta temperatura com ligantes modificados para misturas de módulo elevado de resiliência são iguais ou superiores a $76^{\circ} \mathrm{C}$. Graus maiores de PG (PG 76 e PG 82) atendem a um volume de tráfego maior e/ou menores velocidades (MAGALHÃES, 2004).

\subsection{MISTURAS ASFÁLTICAS}

\subsubsection{Graduação}

A graduação do material é feita através da distribuição dos tamanhos das partículas por meio de peneiramento e é expressa em peso total do material. As especificações de graduação foram criadas com intuito de melhorar as condições do pavimento nos quesitos resistência, aderência e durabilidade. Os agregados se diferem por diferentes graduações: densa, aberta, uniforme e descontínua.

Para misturas de módulo elevado a literatura indica uma graduação contínua e bem distribuída, de maneira que deixe a mistura homogênea para trabalho.A graduação é feita através da escolha de uma série de peneiras cuja malha segue uma ordem decrescente de aberturas, as peneiras usadas na especificação brasileira são as de malha (mm): 76; 38; $19 ; 9,5 ; 4,8 ; 2,4 ; 1,2 ; 0,6 ; 0,3 ; 0,150 ; 0,075$ (NBR - 9935, 2011) A granulometria define se um material atende ou não determinada faixa granulométrica de estudo no qual será empregado. Na Figura 1 observam-se algumas curvas granulométricas empregadas em estudo de misturas asfálticas de módulo elevado para camadas de base de pavimentos no Brasil. Tratam-se de faixas bem próximas à faixa EME0/14, referenciada em parâmetros e estudos franceses. 


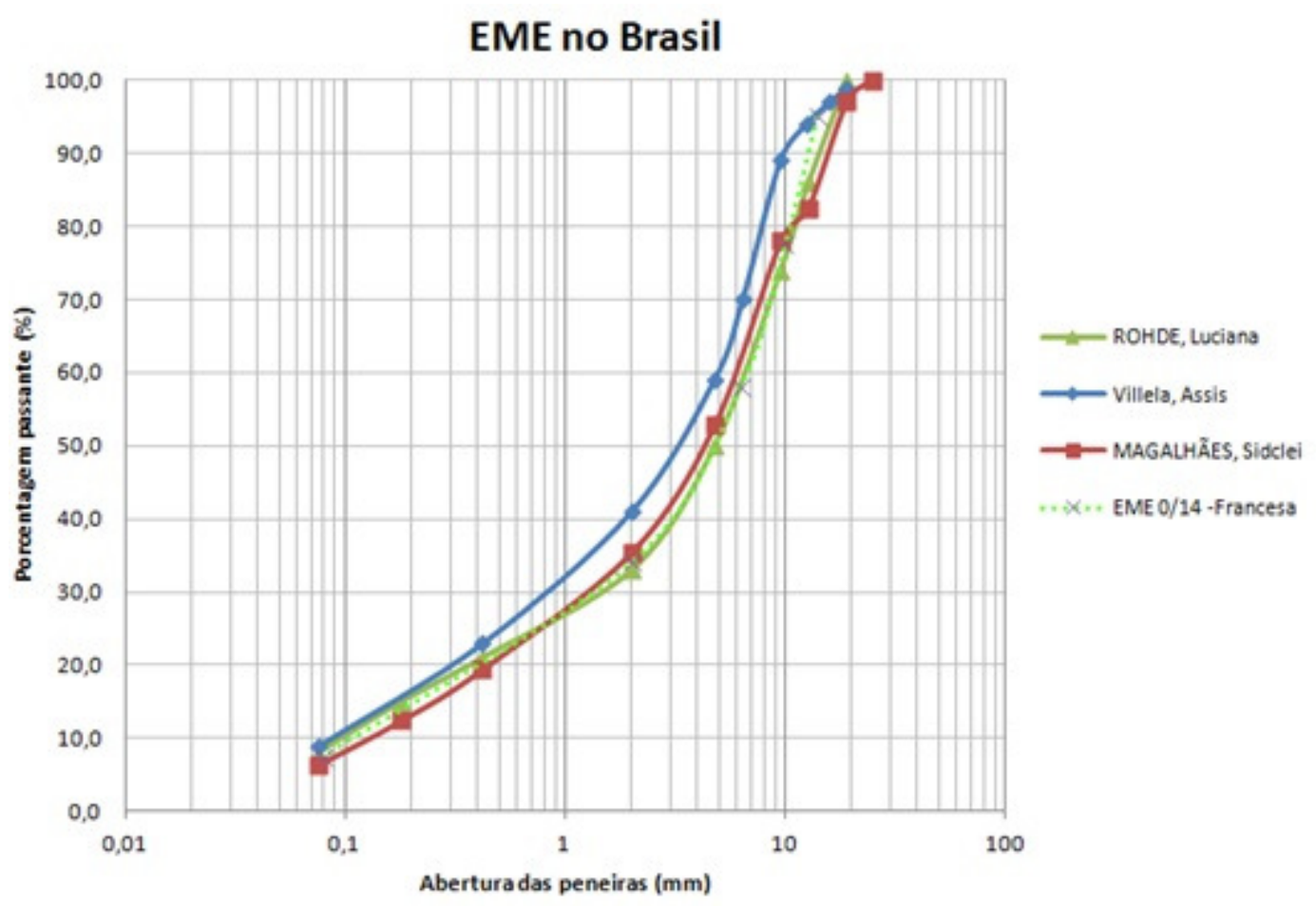

Figura 1 - Curvas granulométricas de EME empregadas em estudos brasileiros

\subsubsection{Avaliação dos agregados combinados}

O método de Bailey foi criado na década de 1980 para auxiliar na seleção granulométrica dos materiais, que depende da compactação entre os grãos da mistura, dos vazios da mistura e dos vazios do agregado mineral. Esta análise visa o melhor intertravamento entres os grãos, principalmente entre os maiores grãos, por ser um fator diretamente relacionado à deformação permanente. Não há restrição quanto à utilização desse método para qualquer tipo de dosagem.

Os parâmetros volumétricos utilizados por esse método são: arranjo dos agregados, que depende do tamanho dos grãos e do método de compactação, e definição de agregado graúdo e miúdo. O método consiste em apresentar a melhor combinação dos agregados em volume para análise da mistura mais adequada. Para este método há definição de agregado graúdo e miúdo, que depende do tamanho nominal máximo da mistura de agregados. Este valor é obtido como sendo a abertura da peneira anterior à primeira que retém $15 \%$ do material. São 
estabelecidas peneiras de controle primária, secundária e terciária e a peneira média de forma que após a seleção do material, pode-se avaliar o comportamento graúdo ou fino da mistura.

\subsubsection{Dosagem}

As propriedades mecânicas de uma mistura asfáltica estão relacionadas ao esqueleto granular e ao tipo e teor de ligante empregado, bem como a interação entre estes dois produtos. Não há uma recomendação de dosagem para misturas de módulo elevado.

A dosagem de misturas asfálticas é feita de maneira que se atendam aos parâmetros físicos e mecânicos desejáveis para uma camada de pavimento após compactação. É através da dosagem que se inicia toda a análise de uma estrutura de pavimento bem como seu comportamento diante dos materiais empregados e das condições de campo sobre as quais o pavimento está submetido. As características avaliadas em uma dosagem são a estabilidade, durabilidade, flexibilidade, impermeabilidade e resistência ao atrito (ROHDE, 2007).

Inicia-se um processo de dosagem pela escolha dos materiais a serem empregados. Esta seleção irá depender principalmente da localização do segmento que será executado ou ainda da escolha do projetista. É importante que se tenha conhecimento dos resultados do projeto de mistura para que se possa avaliar já no início se a mistura atende às especificações.

Os ensaios dos agregados e do ligante que serão empregados na mistura são de extrema importância para conhecimento e comparação entre diferentes tipos de dosagem. O objetivo de uma dosagem é obter como produto uma combinação e graduação de agregados econômica e com teor de asfalto correspondente para que se consiga obter uma mistura com: asfalto suficiente para garantir um pavimento durável; estabilidade suficiente da mistura de maneira a resistir às ações do tráfego, vazios suficientes na mistura compactada de forma a permitir a expansão térmica do 
asfalto sem perda de estabilidade à elevadas temperaturas, trabalhabilidade adequada da mistura, entre outros aspectos e propriedades.

Os resultados de uma dosagem podem inclusive impactar nos custos. Por este motivo é importante que se faça uma análise detalhada do material que será utilizado. $O$ alvo de uma dosagem bem elaborada é sempre buscar pela garantia da estabilidade adequada e durabilidade máxima.

\subsubsection{Rigidez de misturas asfálticas}

Há diferentes formas de determinação de rigidez para caracterização do comportamento mecânico de misturas asfálticas. Emprega-se o termo módulo para determinação desta característica mecânica.

A norma francesa faz referência à obtenção de módulo complexo a $15^{\circ} \mathrm{C}$ numa frequência de $10 \mathrm{HZ}$, carregamento de $0,02 \mathrm{~s}$ para misturas asfálticas, inclusive misturas de módulo elevado. A Figura 2 mostra o resultado dos ensaios de módulo complexo de misturas asfálticas com rigidez distintas (CORTÉ, 2001). Nesta figura pode-se notar maiores valores de módulo complexo para a mistura EME. 


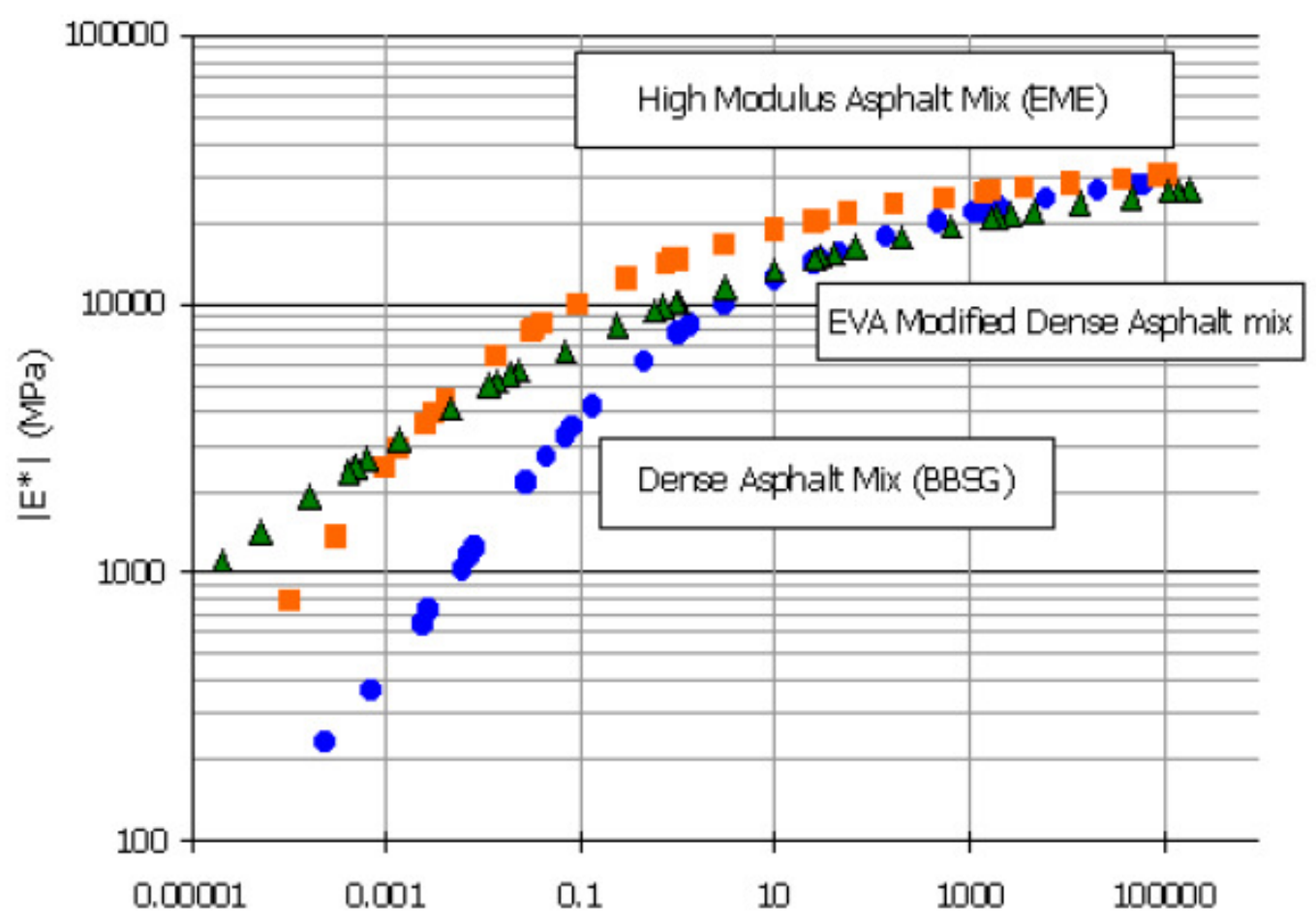

Equivalent Frequency $(\mathrm{Hz})$

Figura 2 - Curvas mestras - resultado de ensaio de módulo complexo de misturas asfálticas, Corté (2001)

No Brasil, comumente é realizado o ensaio de módulo de resiliência a $25^{\circ} \mathrm{C}$ numa frequência de $1 \mathrm{~Hz}$, com período de carregamento de $0,1 \mathrm{~s}$ e descarregamento (repouso) de 0,9s; ou ainda o ensaio de módulo dinâmico, com variação de frequência e temperatura, muito utilizado nos Estados Unidos e em alguns países da Europa.

Os ensaios de módulo de resiliência e módulo dinâmico são dois ensaios com características distintas. A Figura 3 retrata o resultado de cada um destes ensaios em termos de tensão e deformação. Nota-se que o primeiro pico de deformação é bem próximo nos dois ensaios, no entanto, ao analisar o segundo pico, a diferença torna-se visível. O segundo pico é nitidamente maior para o módulo de resiliência, isto ocorre porque o ensaio de módulo dinâmico considera apenas a parcela elástica do pulso de deformação, motivo pelo qual são obtidos valores mais altos de rigidez neste ensaio. Outro fator observado nesta figura é a ausência de período de repouso no ensaio de módulo dinâmico, no ensaio de módulo de resiliência foi aplicado um período de repouso de $0,4 \mathrm{~s}$. 
No trabalho de Hu et al. (2008), há uma proposta de um outro ensaio de módulo, um módulo dinâmico, porém com aplicação do período de repouso entre as cargas. No entanto, este ensaio demandaria muito mais tempo, uma vez que para o ensaio de módulo dinâmico aplicam-se diversas temperaturas em frequências variáveis.

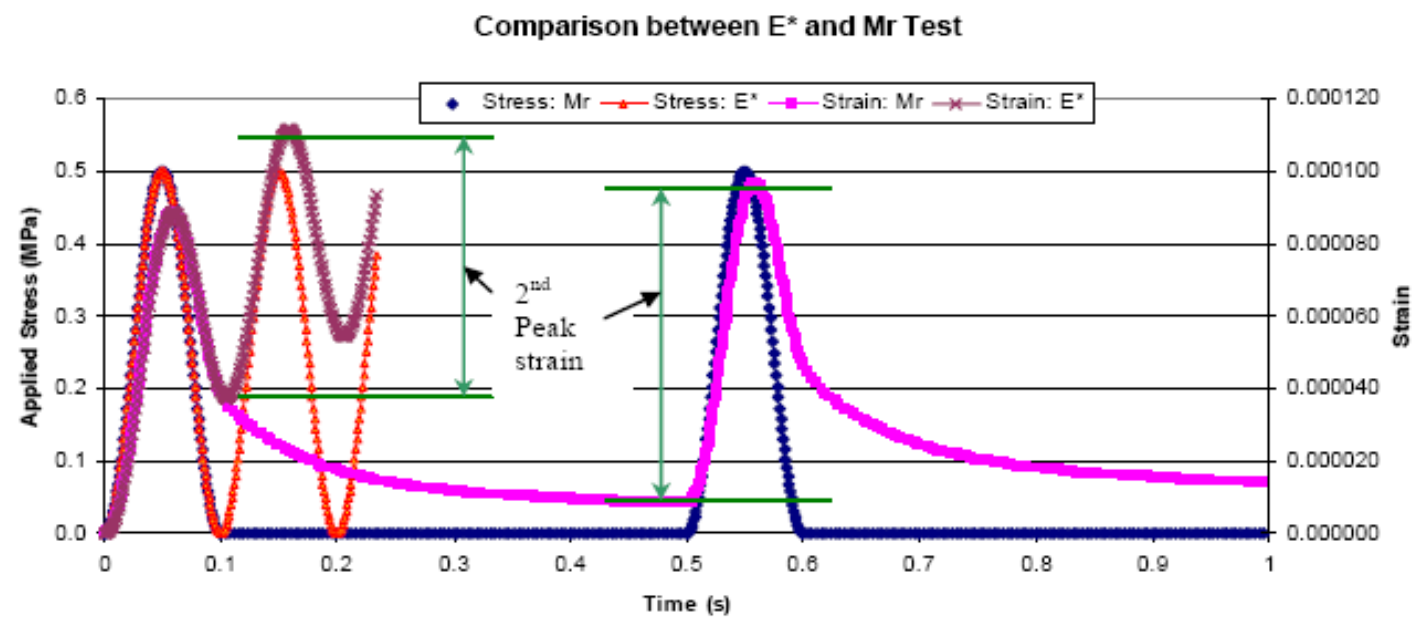

Figura 3 - Comparação entre resultados de ensaio de módulo de resiliência e módulo dinâmico ( Hu et al., 2008).

Algumas diferenças entre os ensaios de módulo de resiliência e o ensaio de módulo dinâmico realizados nesta pesquisa estão representadas na Tabela 1.

Tabela 1 - Diferenças entre os ensaios de módulo de resiliência e módulo dinâmico

\begin{tabular}{l|l|l}
\hline \multicolumn{1}{c|}{ PARÂMETRO } & \multicolumn{1}{|c|}{ MÓDULO DE RESILIÊNCIA } & \multicolumn{1}{c}{ MÓDULO DINÂMICO } \\
\hline Carga & $\begin{array}{l}\text { Carregamento repetido: carregamento } \\
\text { em } 0,1 \mathrm{~s} \text { e descarregamento } \\
\text { (repouso) em 0,9 s }\end{array}$ & $\begin{array}{l}\text { Carregamento dinâmico (desconsidera o } \\
\text { tempo de repouso) }\end{array}$ \\
\hline Carregamento & $\begin{array}{l}\text { Comumente empregado tração } \\
\text { indireta }\end{array}$ & Axial semi-senoidal \\
\hline Plano de aplicação de carga & Diametral & Axial \\
\hline Temperatura & $25^{\circ} \mathrm{C}$ & $54,4^{0} \mathrm{C} ; 37,8^{0} \mathrm{C} ; 21,1^{0} \mathrm{C} ; 4,4^{0} \mathrm{C}$ e $-10,0^{0} \mathrm{C}$ \\
\hline Frequência & $1 \mathrm{~Hz}$ & $0,1 \mathrm{~Hz} ; 0,5 \mathrm{~Hz} ; 1 \mathrm{~Hz} ; 5 \mathrm{~Hz} ; 10 \mathrm{~Hz}$ e $25 \mathrm{~Hz}$ \\
\hline Dimensão do CP & $\begin{array}{l}\text { Comumente empregada: diâmetro de } \\
100 \mathrm{~mm} \text { e altura de } 635 \mathrm{~mm}\end{array}$ & $\begin{array}{l}\text { Diâmetro de } 100 \mathrm{~mm} \text { e } 150 \mathrm{~mm} \text { de altura } \\
\text { ou relação altura- diâmetro de } 2 \text { para } 1\end{array}$ \\
\hline
\end{tabular}

O ensaio de módulo dinâmico pode ser avaliado através de curvas mestras. Pode-se estabelecer comparação entre as curvas mestras obtidas de diversas misturas de 
acordo com suas inclinações, maiores inclinações ocorrem para materiais mais elásticos.

\subsubsection{Fadiga de misturas asfálticas}

A fadiga de uma mistura asfáltica é um ensaio mecânico de importância para o estudo do comportamento do material em dada estrutura proposta. O número $\mathrm{N}$ (vida de fadiga) é dado como sendo $\mathrm{N}$ o número de repetições de uma carga em uma amostra necessária para ruptura do material. $\mathrm{O}$ ensaio de fadiga de mistura asfáltica pode ser realizado a tensão controlada, a deformação controlada ou ainda um ensaio intermediário.

Tensão controlada: é realizado através da aplicação de uma carga sob um corpo de prova cilíndrico ou prismático, submetido a uma frequência constante que simula a passagem do pneu em situações de campo. A literatura indica que ensaios a tensão controlada devem ser realizados para estruturas de pavimento com camadas superiores a $10 \mathrm{~cm}$, pois a mistura vai perdendo sua rigidez com o passar do tempo e sofrendo maiores deformações (LOUREIRO, 2003).

No ensaio a tensão controlada a representação das tensões ocorrem conforme a Figura 4. 


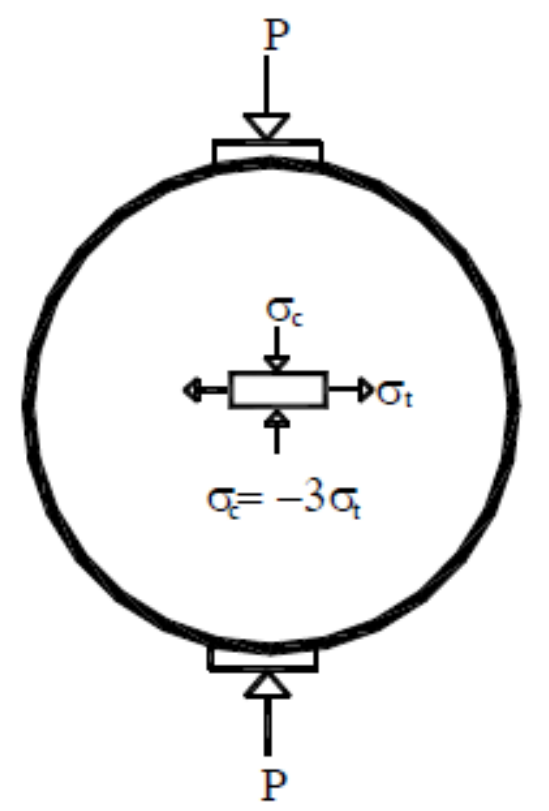

Figura 4 - Representação de tensões no centro da amostra durante ensaio de tensão controlada (LOUREIRO, 2003)

Deformação controlada: é mantida constante a deformação de uma mistura submetida a diversas aplicações de carga até que a ruptura seja evidenciada. Os ensaios a deformação controlada são realizados nos casos em que se obtêm camadas mais esbeltas de pavimento. Há históricos de ensaios realizados a deformação controla através de viga, sendo que no Brasil dificilmente adota-se o ensaio a deformação controlada para corpos de prova cilíndricos (LOUREIRO, 2003).

Em ambos os ensaios deve-se determinar o critério de parada, um parâmetro muito importante para comparação do desempenho a fadiga.

A Figura 5 ilustra o comportamento das tensões e deformações no ensaio de fadiga à tensão controlada e à deformação controlada. 
Tensão Controlada

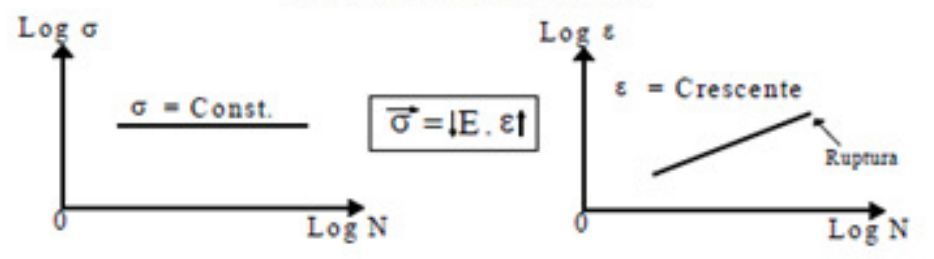

Deformação Controlada

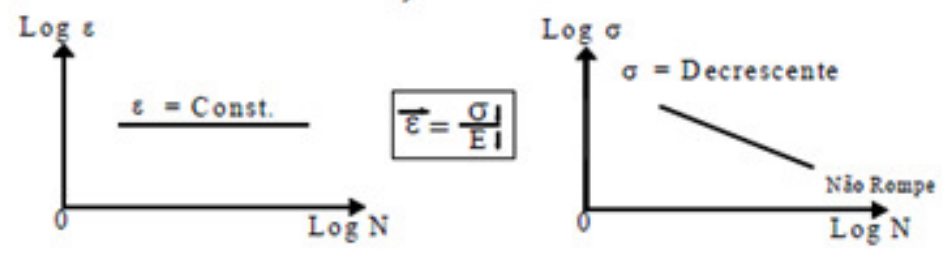

Figura 5 - Relação de tensão e deformação para ensaio de fadiga em misturas asfálticas (LOUREIRO, 2003)

$\mathrm{Na}$ França o ensaio de fadiga é realizado através da flexão em amostras trapezoidais. O ensaio caracteriza-se pela aplicação de uma força na menor extremidade do corpo de prova através de um sistema eletromagnético capaz de gerar uma deformação elástica constante. O critério de ruptura convencional é definido quando a força inicial é reduzida pela metade, sendo a vida de fadiga da mistura definida com sendo o número de aplicações de carga correspondente ao final do ensaio.

A norma francesa indica uma frequência de aplicação de carga de $25 \mathrm{~Hz}$ a temperatura de $10^{\circ} \mathrm{C}$ em um corpo de prova trapezoidal (56 $\mathrm{mm}$ na base maior, 25 $\mathrm{mm}$ na base menor, $250 \mathrm{~mm}$ de altura e $25 \mathrm{~mm}$ de espessura).

\subsection{MISTURAS DE MÓDULO ELEVADO}

O conceito de pavimento de elevada vida de fadiga vem se difundindo ao longo dos últimos anos, sendo que os norte-americanos têm designado essas estruturas de "pavimento perpétuo" (CORTÉ, 2001). Recebem esta denominação pavimentos com duração superior a 50 anos, sendo necessária a manutenção em sua camada de revestimento (MAUPIN e DIEFENDERFER, 2006). 
Os pavimentos perpétuos podem ser classificados como, full depth asphalt pavement quando todas as camadas assentes sobre o subleito são betuminosas. As vantagens destes pavimentos são: reduzir a espessura total do pavimento, diminuir problemas relacionados ao trincamento por fadiga (trincas tipo botton up que ocorrem de baixo para cima, como resultado de repetidas cargas) eminimizar as tensões de tração no fundo da camada asfáltica. Para que essas vantagens sejam atingidas, pesquisas neste tema envolvem a combinação de estudos de deformação permanente, impermeabilidade da camada e resistência ao desgaste e à fadiga.

O objetivo de estudar pavimentos que apresentem uma maior vida de fadiga está na busca pela maior durabilidade e maior qualidade da estrutura projetada, seja desde o subleito, a camada de sub base, a base e o revestimento. A Figura 6 mostra esquematicamente a concepção de um pavimento perpétuo.

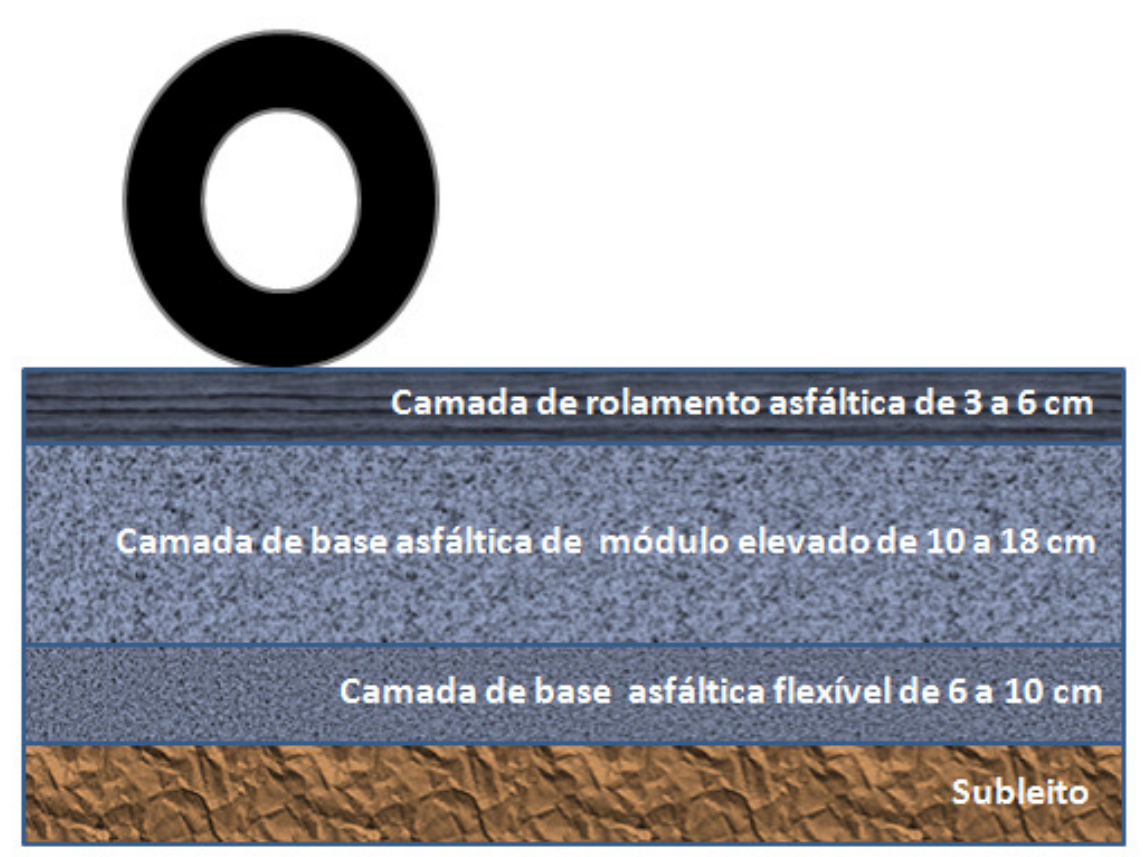

Figura 6 - Seção esquemática estrutura de pavimento perpétuo (adaptado de Corté, 2001)

Diante deste conceito, surgiram misturas asfálticas que apresentam alta resistência à deformação permanente e uma maior vida de fadiga, resultando em uma estrutura de módulo elevado. 
Módulo elevado, representado pela sigla francesa EME, é uma mistura asfáltica composta por agregados seguindo uma curva granulométrica contínua e bem distribuída, com baixo volume de vazios e com alto teor de ligante. Alguns autores têm designado o EME por alto módulo. Neste trabalho emprega-se a terminologia misturas de módulo elevado por opção do autor. O EME é uma camada de base para pavimentos e por este motivo não deve ser empregada como camada final de pavimento.Sobre uma base de módulo elevado deve-se sempre aplicar uma camada de rolamento, ou seja, o revestimento final.

A adoção do módulo elevado sobre a estrutura remanescente pode reduzir em $25 \%$ a espessura final do pavimento, o que resulta em economia de agregado e ligante asfáltico (SETRA e LCPC, 1998). As misturas de EME são caracterizadas pela utilização de ligantes duros, gerando módulos elevados. Misturas como esta devem ser compostas com agregados com diâmetro máximo de $10 \mathrm{~mm}, 14 \mathrm{~mm}$ ou $20 \mathrm{~mm}$, possuem teor de asfalto variando de 5,4 a 6,3\% e espessura de aplicação em torno de 6 a $15 \mathrm{~cm}$ (AVIS TECHNIQUE, $2002{ }^{2}$ ).

O estudo de estruturas de módulo elevado iniciou-se na França com resultados de sucesso, tendo se difundido pela Europa, em países como Portugal, Espanha, e Suíça. Hoje, o emprego de camadas de pavimento com módulo elevado tem sido crescente. Há estudos também países como África do Sul e Brasil. No âmbito brasileiro, a publicação dos estudos se intensificou em meados dos anos $2000 \mathrm{com}$ os trabalhos acadêmicos desenvolvidos por diversas instituições brasileiras. Ao longo desse trabalho, serão citadas algumas experiências brasileiras com módulo elevado.

Como os franceses foram os precursores nessa técnica, boa parte das referências normativas existentes para este tipo de estrutura, hoje, está relacionada às especificações francesas ou européias. Na literatura francesa, há diferentes tipos de misturas asfálticas de módulo elevado, sendo que estas se distinguem pelo diâmetro máximo do agregado que será utilizado:

- EME 0/10 - agregados com diâmetro máximo de 10mm;

- EME 0/14 - agregados com diâmetro máximo de $14 \mathrm{~mm}$, sendo a faixa mais empregada na França;

\footnotetext{
$\overline{2}$ Esta referência faz designação à acessoria técnica denominada Avis Technique-Compodule H, 2002.
} 
- EME 0/20 - agregados com diâmetro máximo de $20 \mathrm{~mm}$.

Pode-se ainda definir a classe de uma estrutura de EME por meio do módulo de riqueza da mistura. A dosagem de asfalto é fixada segundo parâmetros franceses por meio do módulo de riqueza, ou seja, a espessura mínima de filme de asfalto sobre o agregado (DELORME et al., 2007). O módulo de riqueza pode ser calculado através da equação 1 :

$$
\text { Teor de ligante }=k \cdot \alpha \cdot \Sigma^{1 / 5}
$$

Onde :

ké o módulo de riqueza;

a é o coeficiente de correção em função da densidade do agregado, segundo a equação 2:

$$
\alpha=\left(2,65 / D_{\text {ef }}\right) \quad(2)
$$

Onde $D_{\text {ef }}$ é a densidade efetiva da mistura de agregados.

$\sum$ é a superfície específica calculada conforme equação 3 :

$$
\Sigma=0,25 G+2,3 S+12 s+135 f(3)
$$

G é a porcentagem de agregados com diâmetro superior a 6,3mm;

S é a porcentagem de agregados com diâmetro entre 6,3mm e 0,315mm;

s é a porcentagem de agregados com diâmetro entre 0,315mm e 0,075mm;

fé a porcentagem de agregados com diâmetro inferior a 0,075mm.

Segundo a norma francesa, NF-98 140 a classe de EME pode ser definida também pelo valor de k encontrado, por meio da Tabela 2.

Tabela 2 - Limites de módulo de riqueza para misturas de módulo elevado (NF 98-140,1999)

\begin{tabular}{c|c|c}
\hline $\begin{array}{c}\text { EME tipo 0/10, 0/14 e } \\
0 / 20\end{array}$ & EME classe 1 & EME classe 2 \\
\hline $\mathrm{K}$ & 2,5 & 3,4 \\
\hline
\end{tabular}


Há estudos que salientam que módulos de riqueza superiores a 3,2\% representam misturas ricas e caracterizam a mistura que possui um teor de ligante de 5,5 a 6,2\%. Este tipo de mistura apresenta um excelente desempenho mecânico quando se refere aos parâmetros de rigidez, baixo volume de vazios, maior resistência ao dano por umidade, à deformação permanente e maior vida de fadiga. Já as misturas que apresentam um módulo de riqueza entre 2,5 e 3,2 possuem teor de ligante variando de $4,0 \%$ a 5,4\%, e sua diferença em relação às misturas denominadas ricas é basicamente o propósito econômico (SERFASS et al. 1997 apud VILLELA, 2012).

Segundo Corté (2001) podem-se definir as classes de módulo elevado como:

- Classe 1: teor de asfalto reduzido, baixa durabilidade e menor resistência à fadiga, indicada para rodovias de baixo volume de tráfego; e

- Classe 2: alto teor de asfalto, maior durabilidade e maior resistência à fadiga, indicada para rodovias com elevado volume de tráfego.

Estudos recentes têm demonstrado a larga aplicabilidade de misturas de EME classe 2, sendo empregadas como camadas de base para pavimentos. Segundo Quintero (2011), a adoção de mistura de módulo elevado classe 2 para camadas de base pode reduzir em até $30 \%$ a espessura do pavimento.

Misturas com módulo elevado podem ainda ser distinguidas pela sua aplicabilidade, ou seja, podem ser utilizadas para execução de camada de base EME (Enrobé à Module Élevé) ou camada de revestimento BBME (Béton Bitumineux à Module Élevé). Esta última tem como objetivo resistir e dissipar as altas tensões de cisalhamento sofridas pela camada de contato com o pneu do veículo. Neste caso, os tipos de BBME são:

- BBME 0/10 - agregados com diâmetro máximo de 10mm;

- BBME 0/14 - agregados com diâmetro máximo de 14mm.

Não há especificações brasileiras para projetos de misturas de módulo elevado, no entanto os franceses, desenvolveram normas que têm sido empregadas como modelo em diversos países. No que se refere a misturas de módulo elevado, tem-se usado como base normas francesas ou ainda européias. Os países que tem 
desenvolvido estudos com este tipo de misturas tem procurado orientação na norma francesa, adaptando-a aos seus padrões.

A norma NF - 98 140, assim como Delorme et al. (2007), determinam que os ensaios seguindo parâmetros franceses devem seguir os níveis de análise da mistura. Estes níveis são divididos em 4 níveis: nível 1, nível 2, nível 3 e nível 4. Para adequação da mistura seguindo parâmetros franceses de especificações é necessário que se faça a varredura de ensaios e se obedeçam aos critérios de cada um destes níveis previstos em especificações e normas. As Tabelas 3, 4, 5 e 6 mostram as especificações e critérios dos ensaios englobados em cada um destes níveis.

Tabela 3- Nível 1: compactação da mistura (adaptado DEMORME et al., 2007)

\begin{tabular}{|c|c|c|c|c|}
\hline ENSAIO & Classe & $\mathrm{N}^{0}$ de giros(n) & \% de Vazio (máx-mín) & Equipamento \\
\hline \multirow{5}{*}{$\begin{array}{l}\text { Compactação no compactador giratório } \\
\text { Francês } \\
\text { (Diâmetro do cilindro de } 150 \mathrm{~mm} \text { ) }\end{array}$} & EB10-EME 1 & \multirow{2}{*}{80} & $<10$ & \multirow{5}{*}{$\begin{array}{c}\text { PCG - Presse à Cisaillement } \\
\text { Giratorie } \\
\text { (MLPC Tipo 3) }\end{array}$} \\
\hline & EB10-EME 2 & & $<6$ & \\
\hline & EB14-EME 1 & \multirow{2}{*}{100} & $<10$ & \\
\hline & EB14-EME 2 & & $<6$ & \\
\hline & EB20-EME 2 & 120 & $<6$ & \\
\hline
\end{tabular}

Tabela 4 - Nível 2: deformação permanente (adaptado DELORME et al., 2007)

\begin{tabular}{c|c|c|c|c|c|}
\hline ENSAIO & Classe & $\mathbf{N}^{\circ}$ de ciclos & Especificação & \multicolumn{1}{|c|}{ Dados do ensaio } & Equipamento \\
\hline $\begin{array}{c}\text { Deformação Permanente } \\
\text { (Espessura da placa 10 mm) }\end{array}$ & EB-EME 1 e 2 & 30.000 & $<7,5$ & $\begin{array}{l}\text { Frequência de 1 HZ } \\
\text { Carga de } 5 \mathrm{kN} \\
\text { Pressão nos pneus } 6 \text { bar } \\
\text { Temperatura do ensaio } 60^{\circ} \mathrm{C}\end{array}$ \\
\hline
\end{tabular}

Tabela 5 - Nível 3: módulos complexo da mistura (adaptado DELORME et al., 2007)

\begin{tabular}{c|c|c|l|l|}
\hline ENSAIO & Classe & Módulo & \multicolumn{1}{|c|}{ Dados do ensaio } & Equipamento \\
\hline Módulo Complexo & EB-EME 1 e 2 & 14.000 & $\begin{array}{l}\text { Frequência de 10 HZ } \\
\text { Carregamento 0,02s } \\
\text { Temperatura do ensaio } \\
15^{\circ} \mathrm{C}\end{array}$ & MLPC 3 MC \\
\hline
\end{tabular}

Tabela 6 - Nível 4: fadiga a flexão dois pontos (adaptado DELORME et al., 2007)

\begin{tabular}{c|c|c|c|c}
\hline ENSAIO & Classe & $\mathbf{N}^{\circ}$ de ciclos & Especificação & Dados do ensaio \\
\hline $\begin{array}{c}\text { Fadiga a flexão 2 pontos } \\
\text { (corpos de prova prismáticos) }\end{array}$ & EB-EME 1 & \multirow{2}{*}{$10^{6}$} & $\mathrm{e}_{6}-100 \mu_{\text {def }}$ & Frequência de $25 \mathrm{HZ}$ \\
\cline { 2 - 2 } & EB-EME 2 & & $\mathrm{e}_{6}-130 \mu$ def & Temperatura do ensaio $10^{\circ} \mathrm{C}$ \\
\hline
\end{tabular}


Quanto à aplicação em campo, a norma orienta que seja feita uma pintura de ligação asfáltica, para garantir que as camadas que serão interligadas estejam totalmente aderidas. O espalhamento deve ser realizado por meio mecânico, como por acabadora.

Como os asfaltos duros apresentam baixa penetração e alta viscosidade, estas características implicam em temperaturas de trabalhos um pouco mais altas que as misturas convencionais. Assim, estima-se que as temperaturas ideais para boa trabalhabilidade com asfaltos duros seja de $150^{\circ} \mathrm{C}$ a $170^{\circ} \mathrm{C}$ para temperatura final da mistura, e para aplicação, deve ser superior a $140^{\circ} \mathrm{C}$. Para ligantes modificados a temperatura deve ser informada pelo fornecedor (AVIS TECHNIQUE, 2002).

Uma camada de base que trabalha à flexão deve ser resistente ao trincamento por fadiga, que é possível com a utilização de uma mistura de módulo elevado devido à elevada porcentagem de asfalto utilizada em sua composição, ou ainda o uso de uma graduação bem distribuída de agregados. O desafio está em definir uma estrutura rígida de maneira que a tensão de tração na parte inferior da camada asfáltica seja reduzida.

A norma francesa NF P 98-140 indica espessuras de utilização para camadas de módulo elevado conforme Tabela 7.

Tabela 7 - Espessuras de utilização para misturas de módulo elevado ( NF-98 140,1999) 


\subsubsection{Procedimentos para projeto de misturas asfálticas pelo método francês}

Segundo o método francês, existem três principais fatores que estão diretamente envolvidos no processo de obtenção de informação das características de misturas asfálticas:

1. Propriedades físicas, químicas e mecânicas necessárias para avaliação do comportamento dos constituintes da mistura;

2. Ensaios e métodos para se fazer aferição das propriedades volumétricas e mecânicas da mistura;

3. Valores limites admissíveis, determinados experimentalmente, em função das propriedades desejadas no dimensionamento (QUINTERO, 2011).

As propriedades mecânicas de um material são dependentes de sua característica volumétrica, assim a compacidade de uma mistura e, por consequência, seu esqueleto pétreo, interferem diretamente na escolha de um projeto de mistura adequado.

Os franceses orientam sobre os cinco passos empregados em seu método de aplicação de misturas de módulo elevado:

1. Seleção dos materiais a serem utilizados: agregados e ligante, estas informações irão resultar em dados compatíveis de análise pela especificação empregada para cada tipo de mistura;

2. Avaliação do comportamento desses materiais em laboratório por meio da realização de diversos ensaios; em 2006 foram criadas as especificações europeias de asfaltos duros, que incluem requisitos reológicos (VILLELA et al., 2011);

3. Análise do resultado de deformação permanente da mistura;

4. Estudo do módulo complexo obtido em laboratório;

5. Determinação da vida de fadiga (DENNEMAN et al., 2011). 


\subsubsection{Histórico}

\subsubsection{Evolução da produção de asfaltos duros na França}

Asfaltos duros são aqueles cuja penetração é menor que $25 \mathrm{dmm}$ quando encontram-se a uma temperatura de $25{ }^{\circ} \mathrm{C}$. A França é detentora da liderança mundial no uso de asfaltos duros, graças à sua evolução na produção deste material no país. A Tabela 8 mostra a evolução da produção do asfalto duro na França.

Tabela 8 - Evolução de asfaltos duros na França (PIARC, 1998)

\begin{tabular}{c|c|c}
\hline ANO & QUANTIDADE & $\begin{array}{c}\% \text { de } \\
\text { aumento } \\
\text { (base 1990) }\end{array}$ \\
\hline 1990 & $\begin{array}{c}39.000 \\
\text { toneladas }\end{array}$ & \\
\hline 1995 & $\begin{array}{c}77.000 \\
\text { toneladas }\end{array}$ & $97 \%$ \\
\hline 2000 & $\begin{array}{c}100.000 \\
\text { toneladas }\end{array}$ & $156 \%$ \\
\hline
\end{tabular}




\subsubsection{Histórico dos asfaltos densos e misturas de módulo elevado na França}

A Tabela 9 mostra uma síntese histórica dos acontecimentos que levaram à produção de asfaltos cada vez mais duros e do uso de misturas asfálticas de módulo elevado na França.

Tabela 9 - Histórico francês de emprego das misturas de módulo elevado (adaptado CORTÉ, 2001)

\begin{tabular}{l|l}
\hline ANO & \multicolumn{1}{c}{ SITUAÇÃO } \\
\hline 1960 & $\begin{array}{l}\text { Primeiras mudanças: } \\
\text { - material usado: asfalto com classificação PG 80/100 e 180/200 } \\
\text { - necessidade: asfaltos mais rígidos que proporcionassem menores } \\
\text { deformações plásticas } \\
\text { - Justificativa: crescimento de tráfego e aumento da carga axial. }\end{array}$ \\
\hline 1966 & $\begin{array}{l}\text { Produção de asfalto - penetration grade 40/50 e 60/70. } \\
1968\end{array}$ \\
\hline $\begin{array}{l}\text { Produção de asfalto - penetration grade 20/30. } \\
1969\end{array}$ & $\begin{array}{l}\text { Publicação : French Road Directorate } \\
- \text { Finalidade: dividir a França em três zonas climáticas para auxílio na } \\
\text { escolha do tipo de asfalto mais adequado a cada clima: } \\
- \text { Zona 01: Mediterrânea (verões quentes e invernos suaves); } \\
- \text { Zonas 02: Oceânicas (verões e invernos suaves); } \\
- \text { Zonas 03: Continental (verões quentes e invernos frios). }\end{array}$ \\
\hline
\end{tabular}


Modificação do mercado de asfalto francês devido à crise do petróleo. A

1970

França passou a importar petróleo do Oriente Médio, menos denso que 0 da América Central e com isso houve um aumento da demanda por asfalto de penetration grade 40/50 e 60/70.

Impacto das especificações na evolução dos métodos para processar

1980 asfaltos, anteriormente as especificações francesas eram baseadas no valor da penetração.

1986

Introdução do novo sistema de classificação do asfalto - ponto de amolecimento (ensaio do anel e bola: Ring and Boll).

Adoção de requisitos pelos produtores de asfalto:

- limites de enrijecimento nas especificações de asfaltos pós RTFOT 1990 fixados;

- aumento máximo de $9^{0}$ no Ring and Bol-ponto de amolecimento/;

- valor de penetração residual máximo.

1992 Normalização AFNOR (Association Française of Normalization).

Revisão das recomendações para escolha do tipo de asfalto (LCPC -

1994 Laboratorie Central des Ponts et Chaussées e Societé d'Estudes

Techniques des Routes et Eutoroute).. 


\subsubsection{Experiências anteriores com EME}

Experiências francesas relatam a maior durabilidade de uma estrutura cujo material empregado em pelo menos uma camada tenha sido o EME, além de redução significativa na espessura do pavimento (BROSSEAUD, 2002). Na França foram feitos vários segmentos com este tipo de técnica e com condições diversas, desde vias expressas urbanas, rodovias com volume de tráfego maior e até mesmo aeroportos.

No final dos anos 80, o interesse pelas misturas asfálticas de módulo elevado passou a surgir na Espanha. Novamente, trechos experimentais foram executados a fim de se estudar o comportamento e a resposta deste tipo de material. Nos testes executados na Espanha, foram comparados segmentos com misturas convencionais e com aqueles com a aplicação de EME. Neste último caso, houve uma redução de espessura de camada de ate $40 \%$ (VILLELA, 2012). O resultado deste trabalho apresentou dados consideráveis para projeto de estruturas com até $25 \%$ de redução de espessura quando comparadas com misturas convencionais. Em 1992, foram empregadas mistura de módulo elevado para camadas de base e também como solução para recomposição de estruturas já deterioradas(reforço de pavimento antigo em rodovias até mesmo com baixo volume de tráfego).

$\mathrm{Na}$ Suíça, os estudos misturas asfálticas de módulo elevado iniciaram em 2004 por meio de testes em trechos experimentais. A conclusão destes estudos mostrou que a utilização de EME classe 1 não apresentou reduções significativas na espessura das camadas, enquanto que o uso de EME classe 2 levou à redução de até $25 \%$ na espessura da camada de base.

Os portugueses iniciaram seus estudos sobre EME em 1999, sempre envolvendo camada de módulo elevado com $160 \mathrm{~mm}$ de espessura. Estudo desenvolvido por Capitão (2003) resultou em propostas de modelos de previsão para características de deformabilidade das misturas de módulo elevado, referente à fadiga e à deformação permanente. Seguindo alguns modelos desenvolvidos, pôde-se 
estabelecer alguns indicadores de comportamento para as situações do tráfego português. Estes parâmetros podem ser utilizados para informações de dosagem e mesmo como parâmetros para elaboração de especificações.

Na Polônia, em 2003, estudou-se a utilização de EME como camada de base e de BBME para camada de rolamento (BROSSEAUD, 2002). O resultado deste estudo demonstra que esta pode ser uma alternativa para modernização de projetos de pavimento e que isso pode contribuir para uma maior durabilidade da estrutura, maior conforto e segurança ao usuário.

Projetos na California, Oregon e Texas são exemplos em que se aplicaram estruturas de pavimento perpétuos, submetidas a um elevado volume de tráfego e diferentes condições climáticas com sucesso (YANG et al., 2006).

$\mathrm{Na}$ China foram criadas três seções experimentais construídas no verão de 2005. Estruturas de elevada rigidez foram concebidas para avaliar seu comportamento perante $o$ intenso volume de tráfego chinês (na média o volume de tráfego chinês para eixo simples excede 9 toneladas), fato este não muito comum nos EUA. Os autores abordam a possibilidade de desenvolvimento de um projeto de pavimento perpétuo, empregando o software PerRoad (YANG et al., 2006).

O rápido crescimento econômico na última década da China fez com que o país investisse em infraestrutura nacional. Para tanto, foram necessários estudos que viabilizassem o emprego de estruturas de pavimento capazes de suportar o intenso tráfego chinês.

Em 2006, identificou-se a necessidade de implementar novas técnicas de execução de pavimentos na África do Sul (DISTIN et al., 2011). Os estudos desenvolvidos pelos pesquisadores foram baseados em testes de materiais cujo comportamento foi comparado com o desejado e mencionado em normas francesas e européias. A viabilidade de utilização de EME na África do Sul estava vinculada à superação de alguns obstáculos como: habilidade de produzir asfaltos duros nas refinarias da África, integrar a filosofia de concepção de projetos de pavimentos franceses, habilidade de traduzir os projetos de misturas franceses para os padrões de concepção de pavimentos africanos, habilidade de aplicar asfaltos duros na África 
do Sul e finalmente a possibilidade de comercializar este tipo de material e técnica. Os estudos desenvolvidos no país chegaram a boas conclusões na produção de asfaltos duros, estando os mesmos em condições de aplicação, ou seja, estavam de acordo com a norma francesa. Chegaram ainda à conclusão de que ao adicionar aditivos e produzir asfaltos modificados poderiam também contribuir para a utilização deste material para camada de base. Há especificações de ligantes e agregados a serem utilizados na África para estas aplicações. Duas empresas têm investido em estudos para a 0 desenvolvimento de testes para 0 aprimoramento das especificações para mistura de concreto asfáltico para aplicação na África do Sul (DISTIN et al., 2011).

No Brasil, o estudo de Magalhães (2004) compara misturas com ligantes modificados com EVA (AMP EVA) e misturas usinadas com RASF (resíduo asfáltico de petróleo), ambos os ligantes com baixas penetrações, além de misturas com CAP 20 (CAP similar ao CAP 50/70 pela especificação atual). Em seu estudo, Magalhães abordou os valores encontrados para o PG das misturas e verificar o CAP 20 atende a uma região brasileira com PG de 64-16. Foram obtidos para os ligantes com EVA e RASF os PG 76-16 e PG 82-10, respectivamente. As misturas com o ligante modificado, por apresentar baixa penetração, apresentaram módulos de resiliênciamaiores. Os valores de penetração encontrados foram de $55 \mathrm{~mm}, 36 \mathrm{~mm}$ e $9 \mathrm{~mm}$ para o CAP 20, AMP EVA e RASF, respectivamente. Não houve variação do teor de ligante nas misturas estudadas.Foi utilizada a faixa EME 0/14 para um teor de projeto de 5,5\%. A Tabela 10 mostra alguns dos resultados encontrados por Magalhães (2004).

Tabela 10 - Valores de características mecânicas de misturas asfálticas estudadas por Magalhães (2004)

\begin{tabular}{c|c|c|c}
\hline Mistura & $\mathrm{MR} 25^{\circ} \mathrm{C}(\mathrm{MPa})$ & $\mathrm{RT} 25^{\circ} \mathrm{C}(\mathrm{MPa})$ & $\mathrm{MR} / \mathrm{RT}$ \\
\hline CAP 20 & 6.603 & 1,58 & 4.183 \\
\hline AMP EVA & 10.982 & 2,25 & 4.874 \\
\hline RASF & 16.341 & 3,5 & 4.676 \\
\hline
\end{tabular}


Nos ensaios de deformação permanente a 30.000 ciclos em placas com $100 \mathrm{~mm}$ de altura ensaiadas a $60^{\circ} \mathrm{C}$, na frequência de $1 \mathrm{~Hz}$, no simulador de tráfego francês da USP, MLPC, Magalhães (2004) encontrou valores de teor de ligante entre 3,0\% a $4,5 \%$ para as misturas com ligantes modificados após 30.000 ciclos. Estes valores estão abaixo do limite estabelecidos pela norma francesa, percentual de afundamento na trilha de roda inferior a 7,5\%. A mistura com RASF apresentou valores de deformação permanente ligeiramente menores quando comparado com a mistura com AMP EVA, valor esperado pelo autor uma vez que na mistura com RASF o ligante apresentou menor penetração. A mistura com CAP 20 exigiu interrupção do ensaio em virtude da deformação excessiva que impossibilitava a leitura. Com esta mistura as leituras e o ensaio cessaram com 6.600 ciclos.

Os ensaios de fadiga de compressão diametral no trabalho de Magalhães (2004) foram realizados a tensão controlada com variação de níveis de tensão de 10 a 50\% da RT, em uma frequência de $1 \mathrm{~Hz}$ a temperatura de $25^{\circ} \mathrm{C}$. Os CPs foram moldados no compactador Marshall com 75 golpes. Os resultados apontaram para um melhor comportamento à vida de fadiga para as misturas com EVA e ainda melhor para a mistura com RASF.

No entanto, Magalhães (2004) salienta que não é possível comparar diretamente as curvas de fadiga obtidas quando as misturas não possuem parâmetros de rigidez ou módulos de resiliência semelhantes. Isto porque uma mistura mais rígida absorve mais tensões gerando maior tensão de tração.Para a comparação é necessário que se faça um estudo mecanístico com as misturas. As curvas de fadiga encontradas por Magalhães estão representadas na Figura 7 , através do gráfico de $\mathrm{N}$ x diferença de tensões. 


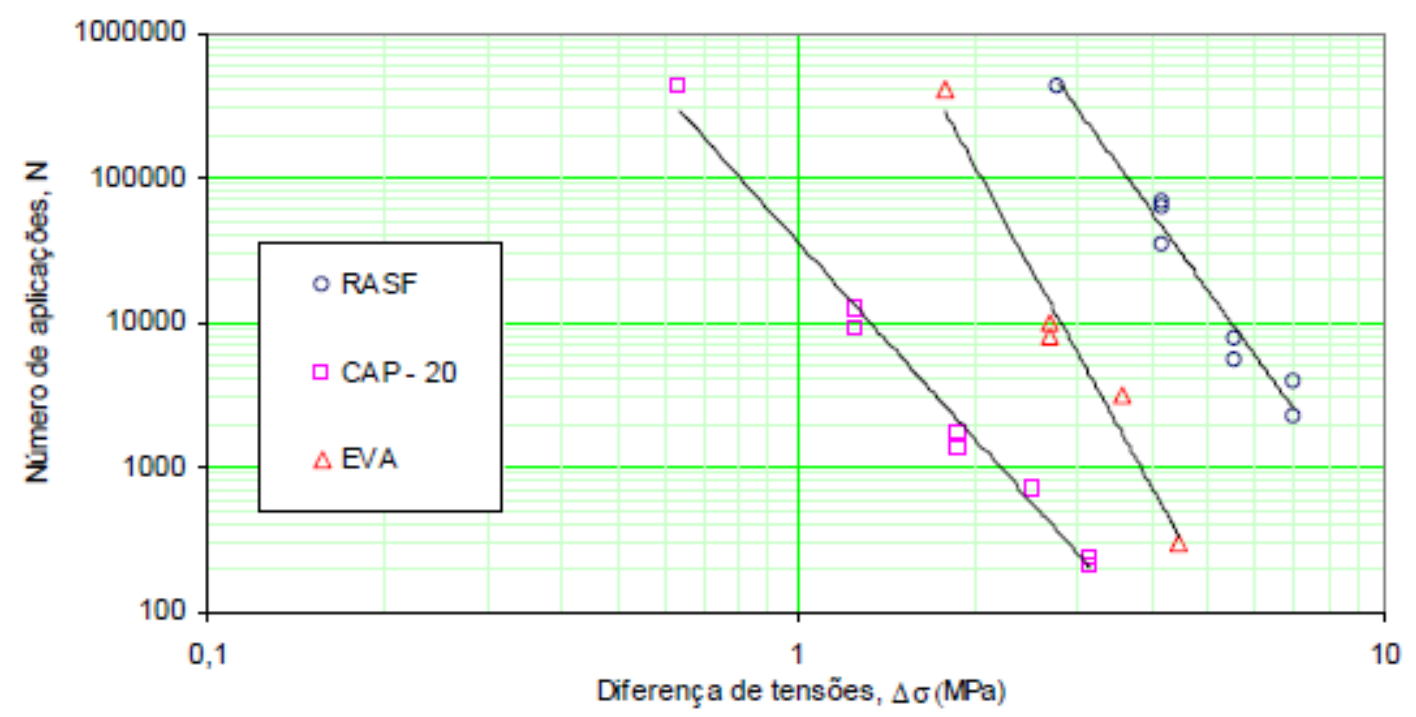

Figura 7- Resultados do ensaio de fadiga por compressão diametral do estudo de Magalhães (2004)

Magalhães (2004) fez o estudo de vida de fadiga para as misturas atenderem a um determinado volume de tráfego e chegou a conclusão de que para $8 \mathrm{~cm}$ de espessura de camada de módulo elevado a mistura com EVA não atendeu às condições admissíveis de tensão para um $\mathrm{N}$ de $10^{8}$.As tensões geradas na base foram sempre superiores às admissíveis pelo tráfego. Para um $\mathrm{N}$ inferior a $10^{7}$ e com espessura de $19 \mathrm{~cm}$ os parâmetros de tensões admissíveis foram atendidos pela mistura com EVA, já a mistura com RASF com uma espessura de $15 \mathrm{~cm}$ atendeu 0 critério de fadiga de $\mathrm{N}$ igual a $10^{8}$, enquanto que a mistura com CAP 20 não atendeu às condições necessárias para uma vida de fadiga para tráfego com $\mathrm{N}$ superior a $10^{7}$ mesmo com espessuras de $20 \mathrm{~cm}$. A estrutura adotada por Magalhães (2004) para análise do comportamento mecânico do pavimento foi de $4 \mathrm{~cm}$ de SMA (Stone Matrix Asphalt), binder em módulo elevado e camada de base composta por CBUQ de 15 cm de espessura, com intuito de reduzir as tensões de tração na camada inferior do módulo elevado para tornar viável a utilização do EVA com $8 \mathrm{~cm}$ de espessura e do RASF com $10 \mathrm{~cm}$ de espessura.

Quanto à resistência a água, obteve-se em todas as misturas estudadas por Magalhães (2004) valores inferiores aos determinados em norma, havendo necessidade de melhorar a adesividade em todos os casos para sua aplicação. 
Freitas (2007) fez uso de escória de alto forno e chegou a resultados melhores do que os obtidos com uma mistura convencional. Empregou CAP 30/45, CAP30/45+4\% de SASOBIT e resíduo de vácuo com características expostas na Tabela 11. A Tabela 12 traz os resultados de módulos de resiliência e de resistência a tração das misturas com os ligantes empregados na pesquisa de Freitas (2007).

Tabela 11 - Características dos ligantes estudados por Freitas (2007)

\begin{tabular}{l|c|c|c|c}
\hline & CAP 50/70 & Resíduo Asfáltico & CAP 30/45+SASOBIT & CAP 30/45 \\
\hline Penetração $\left(100 \mathrm{~g}, 5 \mathrm{~s}, 25{ }^{\circ} \mathrm{C}\right), \mathrm{dmm}$ & 52 & 30 & 23 & 34 \\
\hline PG & $64-22$ & $70-16$ & $76-16$ & $70-16$ \\
\hline
\end{tabular}

Tabela 12 - Valores de características mecânicas de misturas asfálticas estudadas por Freitas (2007)

\begin{tabular}{|c|c|c|c|c|}
\hline \multirow{2}{*}{ Ligante Asfáltico } & \multicolumn{2}{|c|}{ Escória } & \multicolumn{2}{|c|}{ Convencional } \\
\hline & $\mathrm{MR} 25^{\circ} \mathrm{C}(\mathrm{MPa})$ & $\mathrm{RT} 25^{\circ} \mathrm{C}(\mathrm{MPa})$ & $\mathrm{MR} 25^{\circ} \mathrm{C}(\mathrm{MPa})$ & RT $25^{\circ} \mathrm{C}(\mathrm{MPa})$ \\
\hline Resíduo Asfáltico & 8.062 & 1,76 & 7.121 & 1,62 \\
\hline CAP 30/45 + SASOBIT & 9.173 & 1,79 & 9.080 & 1,89 \\
\hline CAP 30/45 & 8.608 & 1,92 & 7.082 & 1,68 \\
\hline
\end{tabular}

Quanto ao ensaio de fadiga por compressão diametral, Freitas (2007) chegou a obter melhores comportamentos para as misturas com escória na seguinte ordem: mistura com CAP 30/45 + SASOBIT (2 A), mistura com resíduo a vácuo (1 A) e mistura com CAP 30/45 (3 A), conforme demonstrado na Figura 8. Freitas desenvolveu um estudo no software FEPAVE2 para análise do comportamento destas misturas no dimensionamento de estruturas de pavimento com elevado volume de tráfego. Os melhores resultados foram representados pela mistura com CAP 30/45+SASOBIT para $\mathrm{N}$ de repetição de carga do eixo padrão de $80 \mathrm{kN}$ de projeto de $10^{8}$. 


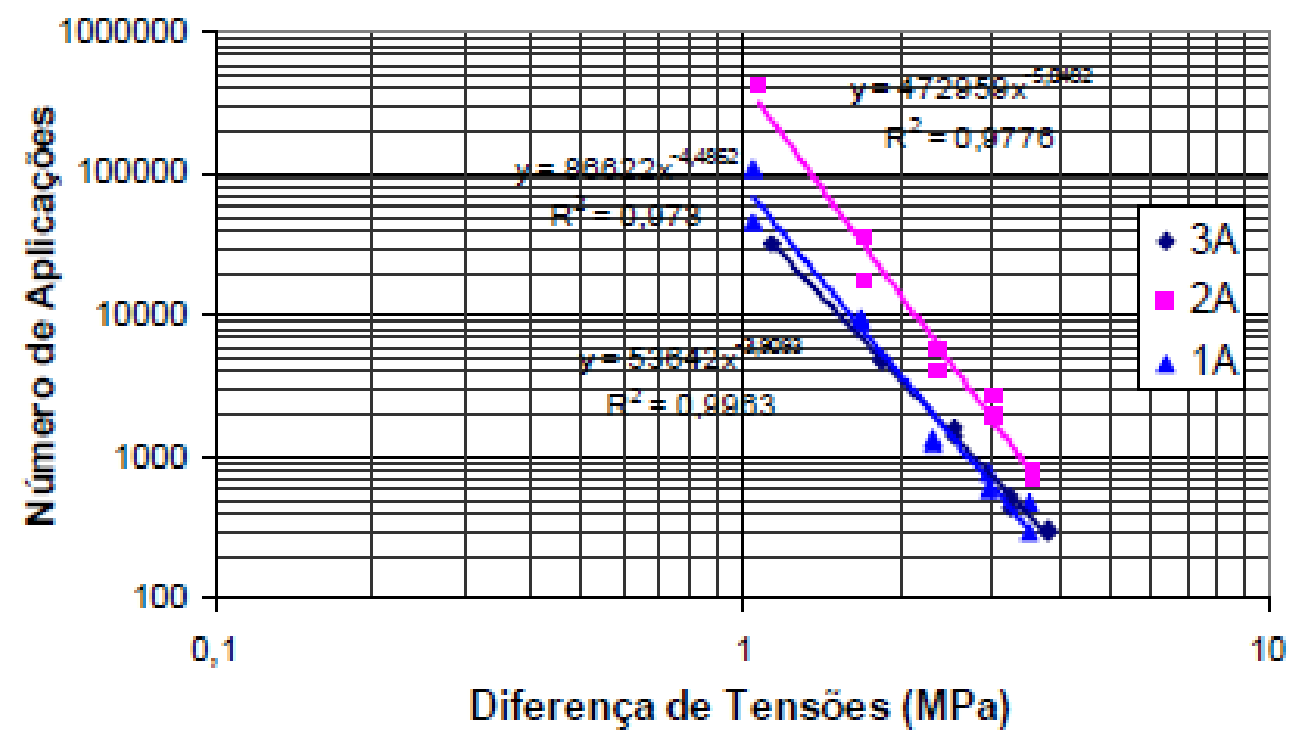

Figura 8 - Resultados do ensaio de fadiga por compressão diametral estudado por Freitas (2007)

Rohde (2007) estudou misturas de módulo elevado para camadas estruturais de pavimento, sendo avaliados diferentes tipos de ligantes. Seu trabalho divide-se em duas etapas de análise da mistura de módulo elevado: etapa laboratorial e etapa experimental, na qual foi feito um segmento em uma pista experimental para monitoramento com a aplicação de módulo elevado como camada de base. $\mathrm{Na}$ etapa laboratorial foram usados os ligantes: CAP 50/70; CAP 30/45 modificado com 1,2\% de ácido polifosfórico; ligante modificado EVA (AMP EVA) e com RASF. Os resultados obtidos por Rohde (2007) na etapa laboratorial estão apresentados Tabela 13. Quanto à resistência ao dano por umidade induzida, as misturas com ligantes especiais atenderam ao limite preconizado pelo SUPERPAVE (Superior Performance Asphalt Pavements) de $80 \%$ obtendo-se um excelente comportamento quanto à adesividade. 
Tabela 13 - Resultados do estudo laboratorial elaborado por Rohde (2007)

\begin{tabular}{l|l|c|c|c|c}
\hline & & CAP 50/70 & PPA 30/45 & AMP EVA & RASF \\
\hline \multirow{2}{*}{ LIGANTE } & Penetração (100g, 5s,25 0 C), dmm & 52 & 28 & 8 & 16 \\
\cline { 2 - 6 } & PG & $64-22$ & $76-10$ & $76-22$ & $82-10$ \\
\hline \multirow{3}{*}{ MISTURA } & Teor de Projeto (\%) & 5 & 5,5 & 5,5 & 5,5 \\
\cline { 2 - 6 } & Volume de vazios (\%) & 2,26 & 1,71 & 2,25 & 2,48 \\
\cline { 2 - 6 } & Módulo de resiliência $25^{\circ} \mathrm{C}(\mathrm{Mpa})$ & 4.861 & 18.217 & 14.479 & 23.805 \\
\cline { 2 - 6 } & Resistência a Tração $25^{\circ} \mathrm{C}(\mathrm{Mpa})$ & 1,2 & 3,53 & 2,39 & 4,29 \\
\hline
\end{tabular}

Rohde realizou ensaio de creep dinâmico para avaliação das deformações recuperável e permanente das misturas com os ligantes utilizados na etapa laboratorial. Como resultado, obteve menores deformações para misturas com RASF. As misturas com AMP EVA e PPA 30/45 apresentaram maiores resistência à deformações quando comparados com misturas com CAP 50/70. Foi realizado também o ensaio de fadiga por compressão diametral a tensão controlada a $25^{\circ} \mathrm{C}$, cujo critério de parada foi a ruptura total dos CP's cilíndricos moldados no compactador Marshall. O resultado desse ensaio pode ser observado na Figura 9.

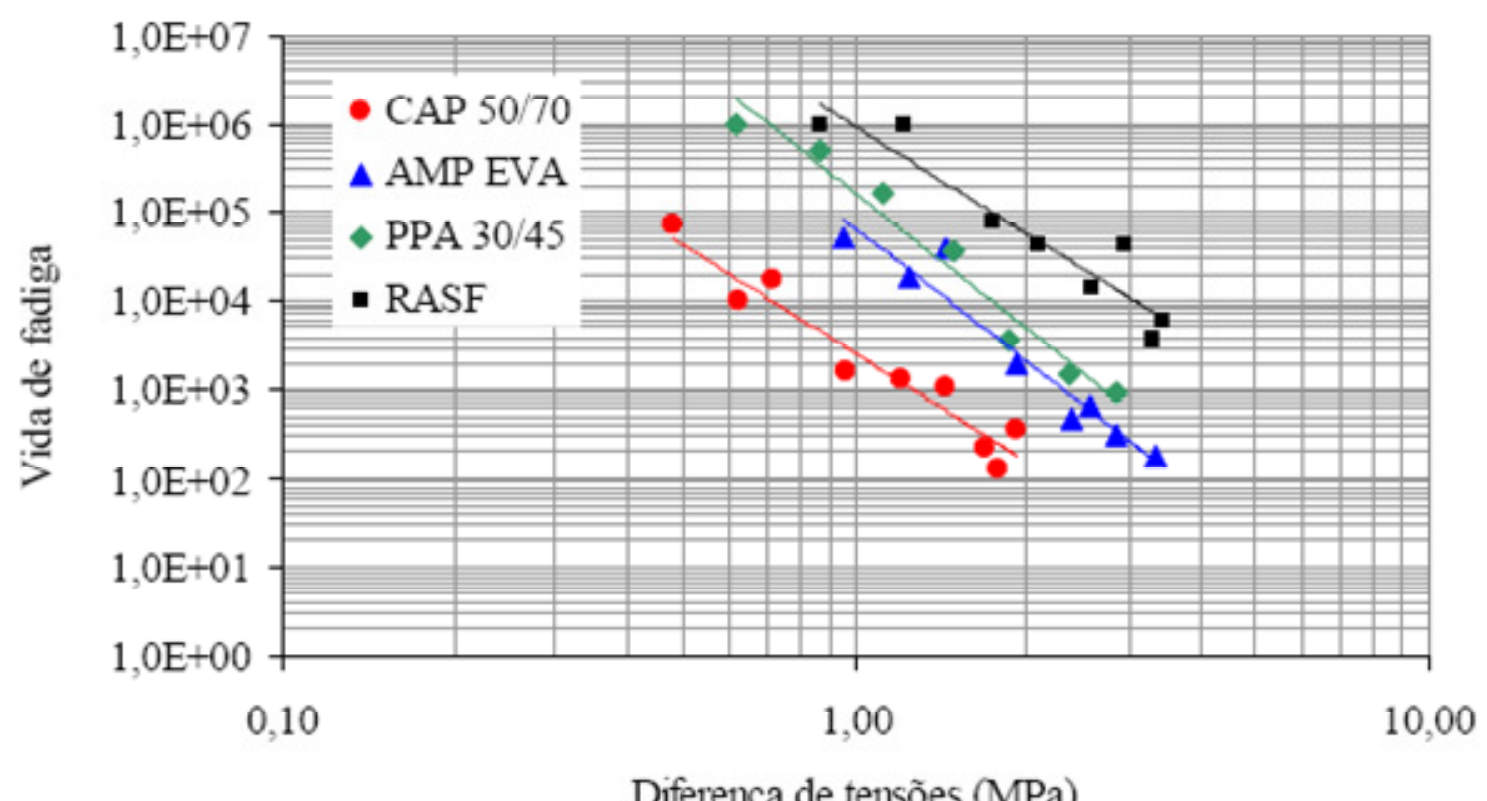

Figura 9 - Resultado do ensaio de fadiga por compressão diametral do estudo de Rohde (2007) Já na etapa experimental, Rohde estudou a possibilidade de utilização de três misturas com ligantes diferentes: uma mistura com utilização de resíduo de vácuo produzido em refinaria de Porto Alegre, uma mistura com CAP 50/70 modificado com 
2\% de ácido polifosfórico e outra mistura com CAPPLUS 106B (produto comercial, modificado por asfaltita). Os valores analisados para estas misturas encontram-se na Tabela 14.

Tabela 14 - Resultados do estudo experimental elaborado por Rohde (2007)

\begin{tabular}{l|l|c|c|c|c}
\hline & & CAP + resíduo a vácuo & $\begin{array}{c}\text { CAP 50/70+ PPA(2\%) } \\
\text { s/cal }\end{array}$ & $\begin{array}{c}\text { CAP 50/70 + PPA(2\%) } \\
\text { c/ cal }\end{array}$ & CAPPLUS 106B \\
\hline \multirow{2}{*}{ LIGANTE } & Penetração $(100 \mathrm{~g}, 5 \mathrm{~s}, 250 \mathrm{C}), \mathrm{dmm}$ & 13 & 26 & 26 & 27 \\
\cline { 2 - 6 } & PG & $76-10$ & $82-10$ & $82-10$ & $70-10$ \\
\hline \multirow{2}{*}{ MISTURA } & Teor de Projeto (\%) & 5,5 & 5,5 & 5,5 & 5,5 \\
\cline { 2 - 6 } & Módulo de resiliência $25^{\circ} \mathrm{C}(\mathrm{Mpa})$ & 18.836 & 6.808 & 5.517 & 10.392 \\
\cline { 2 - 6 } & Resistência a Tração $25^{\circ} \mathrm{C}(\mathrm{Mpa})$ & 2,94 & 1,26 & 1,2 & 1,9 \\
\hline
\end{tabular}

A escolha sobre qual mistura seria aplicada no trecho experimental baseou-se nos fatores: indisponibilidade do material com resíduo a vácuo que seria fornecido pela refinaria e no não atingimento de valores de módulo desejados para uma mistura de EME com o uso do CAP 50/70+ PPA. Houve necessidade de adequar a curva granulomátrica do material com a adição de cal o que acarretou na redução dos efeitos do modificador (redução dos valores de valores de módulos de resiliência) para aplicabilidade do material como módulo elevado. Assim, Rohde (2007) realizou o trecho experimental com a mistura elaborada com o CAPPLUS 106 B. A pista experimental foi feita em duas seções com espessura de EME diferenciadas, seção 1 com 120mm de EME e seção 2 com 80mm de EME, sobre a camada de EME aplicou-se microrrevestimento a frio. A deformação permanente obtida com esta mistura em laboratório foi de 6,66\%, inferior ao limite estabelecido pela norma francesa. Após execução da pista experimental, o trecho com $80 \mathrm{~mm}$ de espessura foi monitorado durante os ensaios acelerados com simulador de tráfego (UFRGSDAER/RS), sendo feitas leituras das bacias de deflexão por meio do deflectógrafo digital. O revestimento não apresentou trincas durante o monitoramento e na mesma seção foram notadas crescentes leituras de deflexão.

Villela (2012) estudou em sua pesquisa um trecho experimental com mistura de módulo elevado aplicada como camada de base, localizado na Rodovia Presidente Dutra entre o km 171 ao km 170, sentido Norte (sentido Rio de Janeiro), na faixa de pesados (faixa da direita). Segundo dados de tráfego, o número $\mathrm{N}$ é de $10^{8}$. Foram feitas aberturas de poços de sondagens das quais se pôde determinar a espessura 
da estrutura do pavimento existente. Em seu trabalho, Villela (2012) identificou cinco seções sendo duas de referência e três seções de teste. Na primeira seção de referência, a estrutura era de reconstrução total até o subleito. A primeira seção experimental foi composta por fresagem de $140 \mathrm{~mm}$ e recomposição em duas camadas de $70 \mathrm{~mm}$ de EME. A segunda seção experimental foi composta por fresagem de $110 \mathrm{~mm}$ e recomposição com EME em duas camadas, a primeira de $60 \mathrm{~mm}$ e a segunda de $50 \mathrm{~mm}$. A terceira seção experimental foi composta por fresagem de $80 \mathrm{~mm}$ e recomposição com EME em uma única camada de $80 \mathrm{~mm}$. Por fim, a segunda seção experimental de referência foi composta por fresagem de $80 \mathrm{~mm}$ e recomposição em única camada de $80 \mathrm{~mm}$ de CBUQ convencional com CAP 30/45. O ligante de baixa penetração empregado para a mistura foi classificado como PG 82-10. Após definição do projeto de mistura e feita a dosagem Marshall, com teor de projeto com 5,8\% de ligante, a mistura foi compactada no compactador giratório francês, no qual obtiveram-se vazios de $4,5 \%$, inferior ao limite estabelecido pela norma francesa de $6 \%$ para 100 giros. Os resultados de deformação permanente encontrados para a mistura empregada no segmento experimental foram inferiores ao limite máximo estabelecido por norma, sendo encontrado valor de deformação permanente de $1,2 \%$ após 30.000 ciclos no simulador de tráfego LCPC do Laboratório de Tecnologia de Pavimentação da USP. O trabalho contempla também estudo paramétrico de aplicação de misturas de módulo elevado para camada de base assentes sobre uma estrutura remanescente. O revestimento empregado no estudo foi uma camada de rolamento de mistura asfáltica delgada com atribuição funcional. Villela encontrou, através das bacias de deflexão, valores deflectométricos do substrato remanescente mínimos de $10 \times 10^{-2} \mathrm{~mm}$ e máximos superiores a $110 \times 10^{-2} \mathrm{~mm}$. Os valores de módulo de resiliência na estrutura de EME retroanalisados variaram de 10.000 a $14.256 \mathrm{MPa}$.

No Brasil, o estudo envolvendo ligantes de baixa penetração tem aumentado nos últimos anos, pois a sua utilização pode ser interpretada como uma proposta promissora em estruturas de pavimento com alto volume de tráfego. A produção de CAP duro no Brasil ainda está em fase de crescimento, mas há grandes perspectivas deste material ser utilizado em larga escala, visto que há uma demanda por estruturas mais resistentes ao crescentes volume de tráfego cada vez maior. $\mathrm{O}$ 
EME é uma ótima alternativa para pavimentos aeroportuários, terminais e corredores de ônibus, praças de pedágio, balanças de controle de pesagem para veículos comerciais e ainda pátios e estacionamentos de manobras de veículos comerciais (VILLELA, 2012). 
Este capítulo contém informações sobre os procedimentos de laboratório adotados para ensaios e os resultados obtidos com a caracterização dos materiais empregados ao longo desta pesquisa. As características dos materiais (agregado e ligante) estão apresentadas neste capítulo de maneira a orientar a fase preliminar de estudos do comportamento das misturas asfálticas de módulo elevado por meio de ensaios mecânicos realizados no laboratório.

O trabalho contou com o apoio de três laboratórios: o Laboratório de Tecnologia de Pavimentação - LTP sediado na Escola Politécnica da Universidade de São Paulo, o Centro de Pesquisas Rodoviárias da Concessionária NovaDutra, sediado na Rodovia Presidente Dutra e o Laboratório de Estradas, sediado na Escola de Engenharia de São Carlos. Em alguns casos, os ensaios puderam ser realizados em mais de um laboratório, em outros casos, foi possível a realização de ensaios específicos pelo laboratório detentor do equipamento. A utilização de três laboratórios distintos contribuiu para a realização de uma sequência produtiva de caracterização do material e compreensão das misturas estudadas.

\subsection{AGREGADOS}

\subsubsection{Origem}


Os materiais utilizados para fins desta pesquisa foram agregados originados da Pedreira Jambeiro, localizada na região Sudeste do Brasil, na cidade de JambeiroSP, conforme mostra a Figura 10. Trata-se de uma rocha gnaissica com granulação média e cor acinzentada.

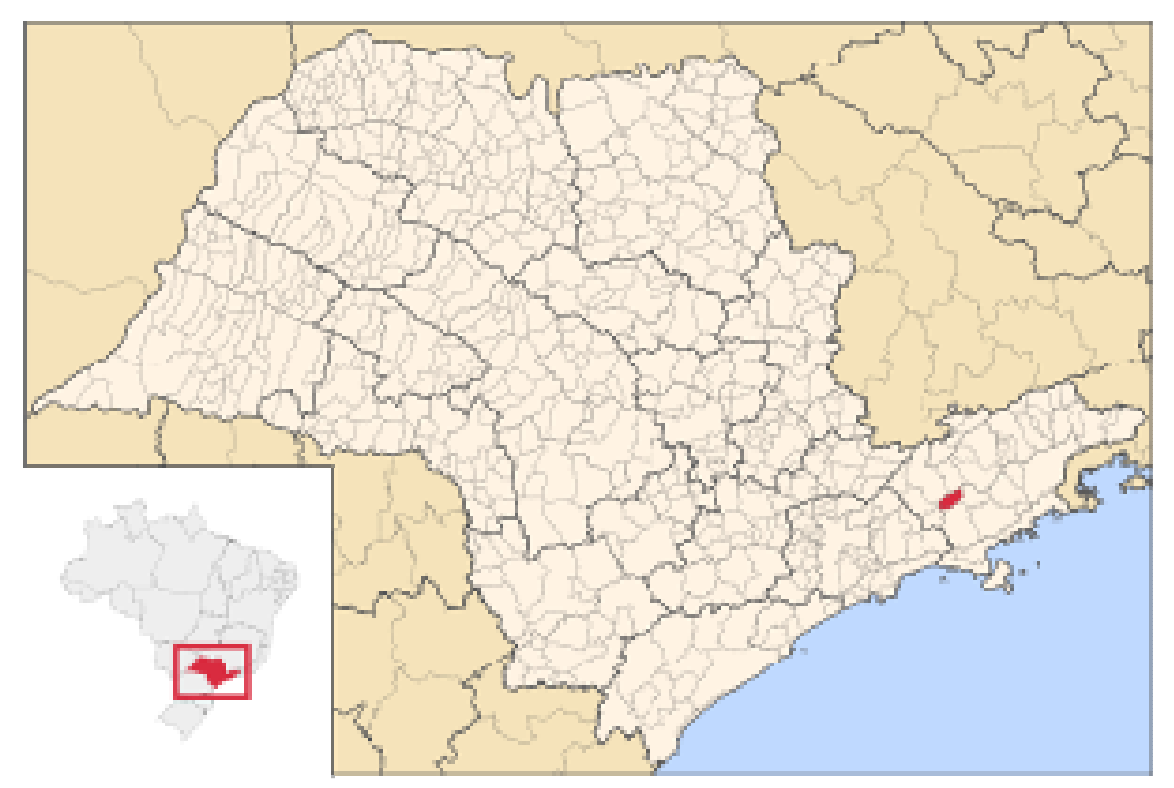

Figura 10 - Localização de Jambeiro no Estado de São Paulo

\subsubsection{Análise Petrográfica}

A descrição macroscópica dos fragmentos avaliados resultaram na cor cinza médio e estrutura gnáissica/bandada; há alternância de bandas de espessura rosadas com granulação mais grossa, enriquecidas com feldspato potássico e às vezes biotita.

A natureza dos fragmentos é mineralógica, de pouco a médio grau de alteração; o estado microfissural pode ser considerado ausente. Há presença de quartzo que pode ser considerado reativo, assim é recomendável a realização de ensaio de 
reatividade potencial. A Figura11 traz uma descrição da rocha bem como uma imagem.

Sua classificação é biotita-gnaisse.

COMPOSIÇÃO MINERALÓGICA (avaliação visual - \%)

PRINCIPAL

Plagioclásio (oligoclásio)

Quartzo

Microclinio

Biotita

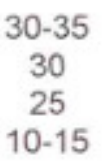

SUBORDINADA

Opacos

Apatita

Zircảo

\section{SECUNDÁRIOS}

Sericita, muscovita, carbonato

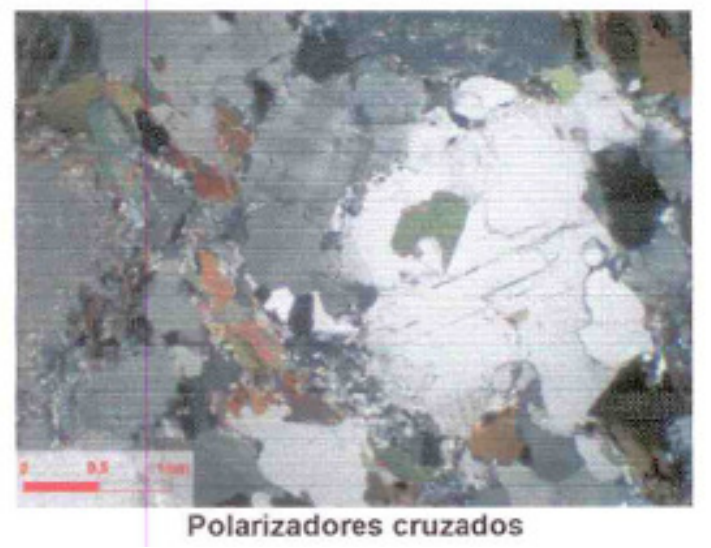

Figura 11 - Imagem fotográfica da composição mineralógica da rocha de origem dos agregados

\subsubsection{Ensaios nos agregados}

Os ensaios de caracterização dos agregados foram realizados no centro de Pesquisa Rodoviária - CPR NovaDutra. Os ensaios realizados nesta pesquisa foram:

- equivalente de areia, referenciado na norma brasileira NBR 12052/1992- Solo ou agregado miúdo - Determinação do equivalente de areia. Este ensaio determina a proporção de argila ou pó em amostras de agregados miúdos. Estes agregados são colocados em uma proveta, juntamente com uma solução de cloreto de cálcio-glicerina-formaldeído, e mantido em repouso por 20 minutos. Este material é agitado por 30 segundos após o repouso; em seguida a proveta é preenchida até nível determinado com a mesma solução; 
o material é mantido em repouso por mais 20 minutos; posteriormente, procede-se à leitura do material que sedimentou e o material que ainda se encontra em suspensão; a relação entre estas duas alturas é o equivalente de areia.

O equivalente de areia dos agregados deste estudo apresentou o valor de $57 \%$. Segundo DNER (1997), para que um agregado possa ser utilizado em concreto asfáltico, o equivalente de areia deve ser pelo menos $55 \%$. Desta forma, os agregados empregados nesta pesquisa atendem aos parâmetros exigidos para sua utilização. A Tabela 15 mostra os resultados obtidos no ensaio de equivalente de areia no agregado em estudo.

Tabela 15 - Resultado do ensaio de equivalente de areia

\begin{tabular}{l|c|c|c}
\hline AMOSTRAS & $\mathbf{1}$ & $\mathbf{2}$ & $\mathbf{3}$ \\
\hline DETERM INAÇõES & 5,9 & 6,2 & 5,6 \\
\hline Leitura do topo de areia (A) & 10,8 & 10,6 & 9,7 \\
\hline Equra no topo da argila (B) & 55 & 58 & 58 \\
\hline \multicolumn{2}{c}{ MÉDIA - Eq. Areia (\%) $\mathbf{5}$} \\
\hline
\end{tabular}

- densidade aparente dos agregados combinados (INSTITUTO DO ASFALTO, 2002);

- densidade efetiva dos agregados combinados (INSTITUTO DO ASFALTO; 2002);

- densidade máxima da mistura referenciado pela norma americana AASHTO T 209/2005: Theoretical maximum specific gravity and density of bituminous paving mixtures;

- abrasão Los Angeles, referenciado na norma brasileira ABNT NBR NM51/2001: Ensaios abrasão "Los Angeles". Este ensaios consistem em avaliar o desgaste sofrido pelo agregado, quando ensaiado na máquina "Los Angeles", juntamente com um conjunto de esferas metálicas denominadas carga abrasiva. Este material, juntamente com as esferas metálicas, passarão por revoluções a uma velocidade que pode variar de $30 \mathrm{rpm}$ a $33 \mathrm{rpm}$, até 
que se completem as rotações determinadas em norma para o tipo de graduação detectada. $O$ resultado do ensaio é expresso pela porcentagem, em peso, do material que passa pela peneira de $1,7 \mathrm{~mm}$.

No ensaio de Abrasão Los Angeles, a amostra de agregado utilizado atendeu aos parâmetros normativos brasileiros, com um resultado de abrasão inferior a $40 \%$ (ABNT, 2001). O resultado no ensaio de Abrasão Los Angeles na amostra foi de $34 \%$, ou seja, o desgaste sofrido pelos agregados é aceitável para uma boa estrutura pétrea. Foram utilizadas para elaboração deste ensaio 11 esferas metálicas e 500 rotações.

- índice de forma dos agregados, referenciado na norma brasileira NBR 7809/2006: Agregado Graúdo -Determinação do índice de forma pelo método do paquímetro. Este ensaio mede a relação entre espessura e comprimento dos grãos do agregado de cada fração granulométrica, sendo o comprimento a maior dimensão possível do grão e a espessura a menor distância possível entre planos paralelos. $O$ resultado é dado pela média ponderada entre as relações de comprimento e espessuras de todos os grãos medidos. $O$ resultado deve ser arredondado para o décimo mais próximo. $O$ índice de forma do agregado em estudo foi atendido, uma vez que apenas $10 \%$ dos grãos apresentaram a razão entre comprimento e espessura superiores a 3. As leituras foram feitas para 62 amostras de agregado.

\subsection{LIGANTES}

O estudo envolve a avaliação e comportamento de misturas asfálticas elaboradas com três diferentes ligantes asfálticos. $O$ foco do trabalho são as misturas asfálticas de módulo elevado, cujo ligante asfáltico envolvido é denominado CAP duro ou ainda CAP para módulo elevado. Estes ligantes foram caracterizados e comparados 
com um ligante convencional CAP 30/45 para melhor entendimento do comportamento conjunto da mistura.

Os ligantes foram fornecidos por empresas que atuam no mercado de pavimentação e cedido para pesquisa pela Centro de Pesquisas Rodoviárias - NovaDutra. O trabalho envolve a comparação de dois ligantes para misturas de módulo elevado CAP A e CAP B, e um ligante convencional CAP 30/45.

Os ligantes foram coletados diretamente da carreta para que fosse evitada a contaminação e foi armazenado em latas de 18L. Posteriormente, após aquecimento, foram distribuídos em latas de 3,6L.

Os ensaios de caracterização do ligante foram realizados no Centro de Pesquisa Rodoviária- NovaDutra e os ensaios reológicos foram realizados no Laboratório de Estradas da Escola de Engenharia de São Carlos. Os ensaios empregados para caracterização do ligante nesta pesquisa foram:

- determinação da penetração do ligante, referenciado na norma brasileira ABNT NBR 6576/2007: Materiais Asfálticos - Determinação da penetração. A penetração é a distância em décimos de milímetros que uma agulha penetra sobre uma amostra em condições pré determinadas de temperatura e carga. Este ensaio é realizado à temperatura de $25^{\circ} \mathrm{C}$ em banho de água. Uma amostra de ligante é colocada e submetida à penetração de uma agulha com sobrecarga de $100 \mathrm{~g}$ durante $5 \mathrm{~s}$. São realizadas três leituras e o valor da penetração é o valor resultante da média de três determinações. A Figura 12 mostra o equipamento utilizado para determinação da penetração de ligantes asfálticos. 


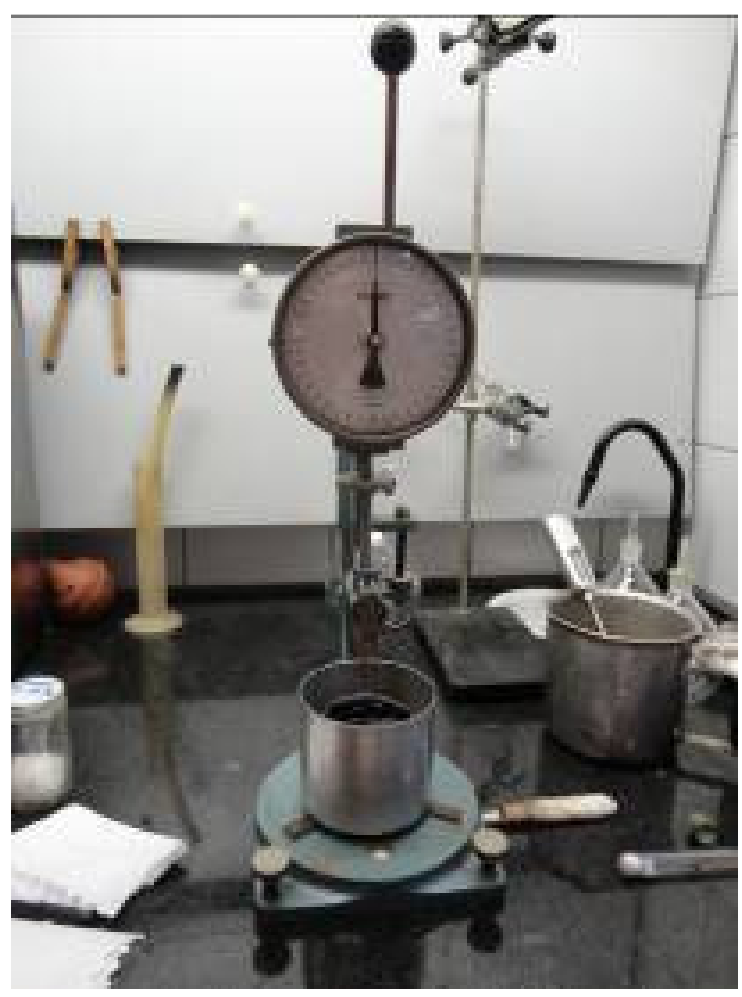

Figura 12 - Equipamento para o ensaio de penetração em amostra do ligante instalado no CPR-NovaDutra

- determinação da viscosidade do ligante em temperaturas elevadas referenciado na norma brasileira - ABNT NBR 15184/2004: Materiais Betuminosos - Determinação da viscosidade em temperaturas elevadas usando um viscosímetro rotacional. A viscosidade é a medida de consistência dos ligantes; esta propriedade é determinada pelo ensaio em viscosímetro rotacional, através da medição do torque necessário para rodar uma haste de prova, denominada spindle, imersa em uma amostra de ligante em uma dada temperatura e submetida a uma velocidade constante de $20 \mathrm{rpm}$. Foram medidas a viscosidade dos ligantes asfálticos utilizados nesta pesquisa nas temperaturas de $135^{\circ} \mathrm{C}, 150^{\circ} \mathrm{C}$ e $177^{\circ} \mathrm{C}$ a $20 \mathrm{rpm}$ no equipamento denominado Viscosímetro Brookfield, conforme mostra Figura 13. 


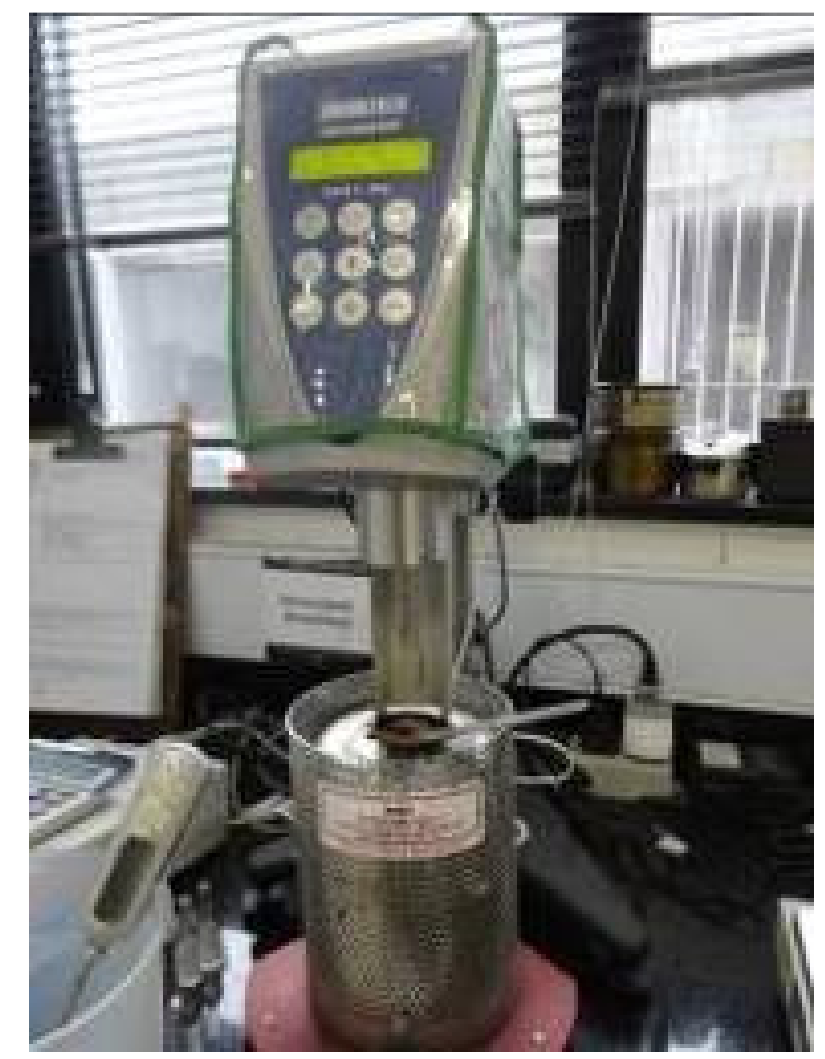

Figura 13 - Equipamento para o ensaio de viscosidade no Viscosímetro Brookfield instalado no CPR-NvaDutra

- determinação do ponto de amolecimento do ligante referenciado na norma brasileira - ABNT NBR 6560/2008: Materiais Betuminosos - Determinação do ponto de amolecimento - Método do anel e bola. Este ensaio consiste em moldar uma amostra de ligante em um anel metálico. O anel é colocado sobre um aparato de ensaio e mantido suspenso em uma solução de Etileno-Glicol, sob controle de temperatura. Sobre este molde contendo a amostra de ligante, é colocada uma esfera de aço. Este conjunto passa por um aumento de temperatura constante, o que faz com que o ligante amoleça dentro do molde e ceda ao peso da bola, deslocando-se até o ponto em que toque uma placa na horizontal de referência do equipamento, localizada a uma altura de 25,4 mm de distância do molde. O ponto de amolecimento é dado pela temperatura em que o ligante amolecido toca a placa horizontal instalada abaixo do par de anéis, conforme mostra a Figura 14. 


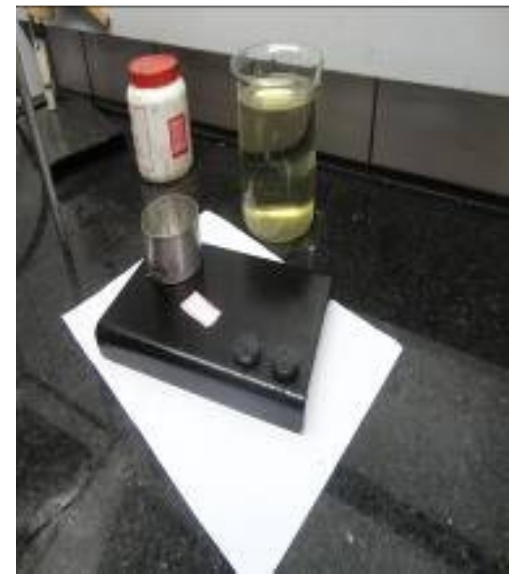

a) Preparação dos anéis preenchimento com ligante

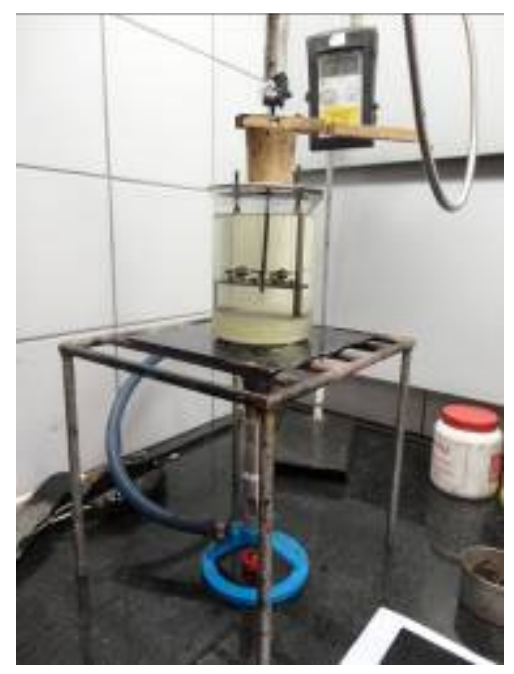

d) Imersão do suporte com anéis e bola no banho(etileno glicol) submetido ao acréscimo de temperatura

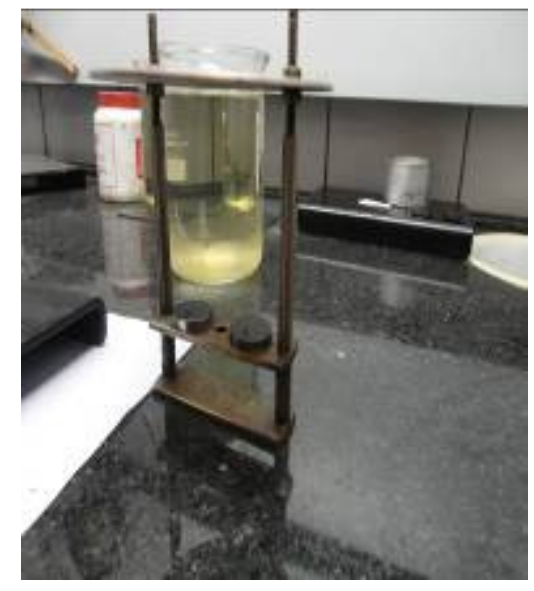

b) Moltagem do suporte para imersão no banho

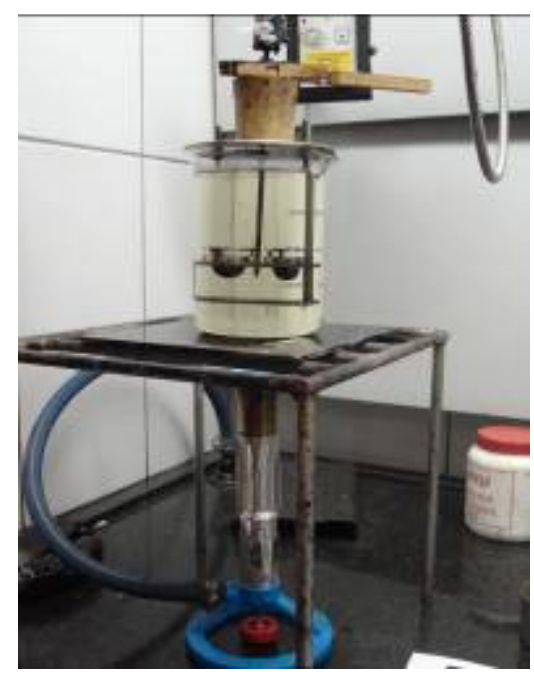

e) Início do ensaio - a bola já começa a penetrar sobre o anel de ligante

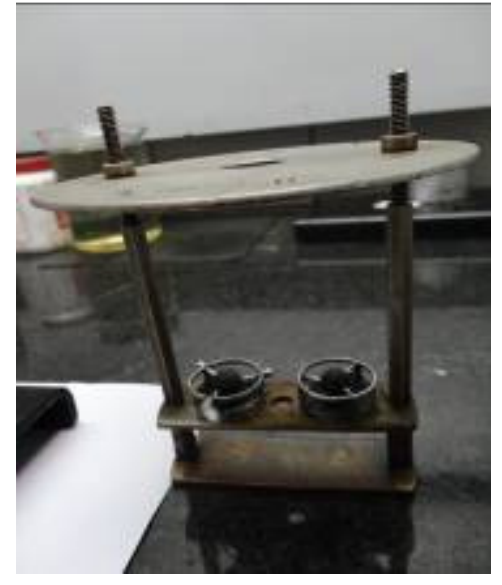

c) Colocação das bolas (esferas) metálicas sobre 0 anel com ligante

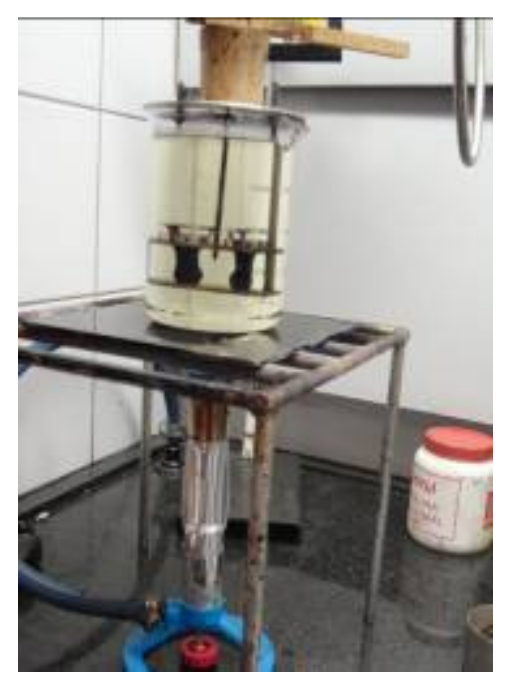

f) Término do ensaio - tempo em que a bola envolta pelo ligante toca a chapa metálica inferior

Figura 14 - Sequência de ensaio de Ponto de Amolecimento - anel e bola, CPR-NovaDutra

- determinação da densidade e da massa específica, referenciada na norma brasileira - ABNT NBR 6296/2004: Produtos Betuminosos semi-sólidos Determinação da massa específica e densidade relativa. Este ensaio consiste em determinar a densidade- relação entra a massa do ligante a $25^{\circ} \mathrm{C}$ e a massa de água a $4^{0} \mathrm{C}$. A relação entre massa e volume é a massa específica. A amostra é colocada em um picnômetro e pesada, posteriormente, completase este conjunto com água. A temperatura de ensaio é mantida em $25^{\circ} \mathrm{C}$ e 
pesa-se o conjunto. A densidade é calculada a partir da massa total e da massa de água deslocada pela amostra no picnômetro, conforme Figura 15.

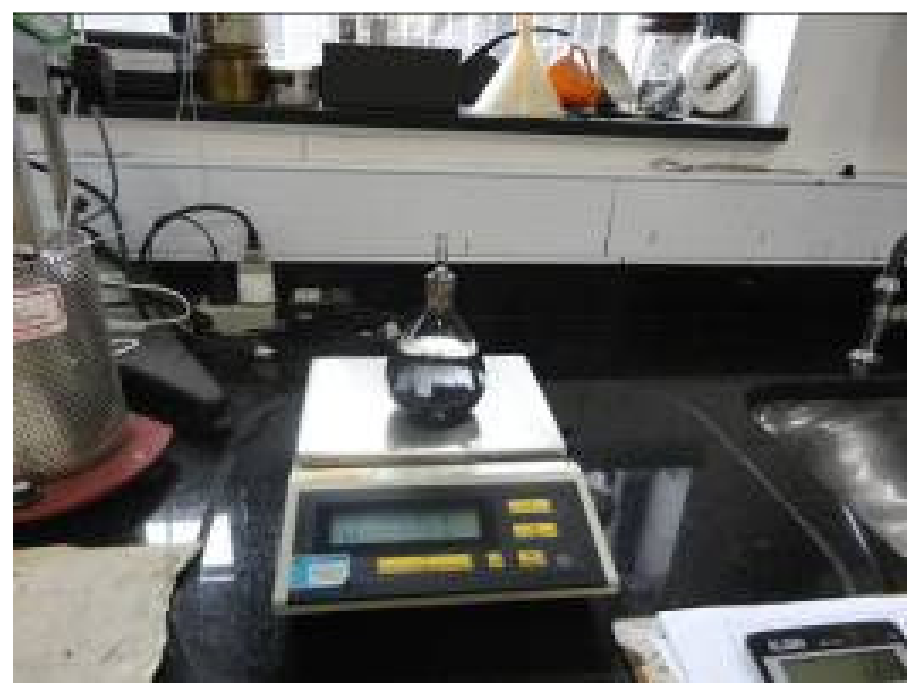

Figura 15 - Determinação da massa do picnômetro preenchido metade com água e metade com asfalto a $25^{\circ} \mathrm{C}$

- ensaios em regime oscilatório para determinação do grau de desempenho dos ligantes asfálticos à temperatura elevada: foram realizados nas amostras virgens, conforme procedimento descrito na ASTM D7175 - Standad Test Method for Determining Rheological Properties of Asphalt Binder Using a Dynamic Shear Rheometer. Estes ensaios foram realizados no reômetro da marca TA Instruments, modelo AR-2000ex, instalado na Escola de Engenharia de São Carlos e foram efetuados pela equipe técnica do Laboratório de Estradas do Departamento de Engenharia dos Transportes da EESC-USP. A Figura 16 mostra uma foto do equipamento empregado. $O$ ensaio foi realizado para os ligantes asfálticos CAP A, CAP B e CAP 30/45. 


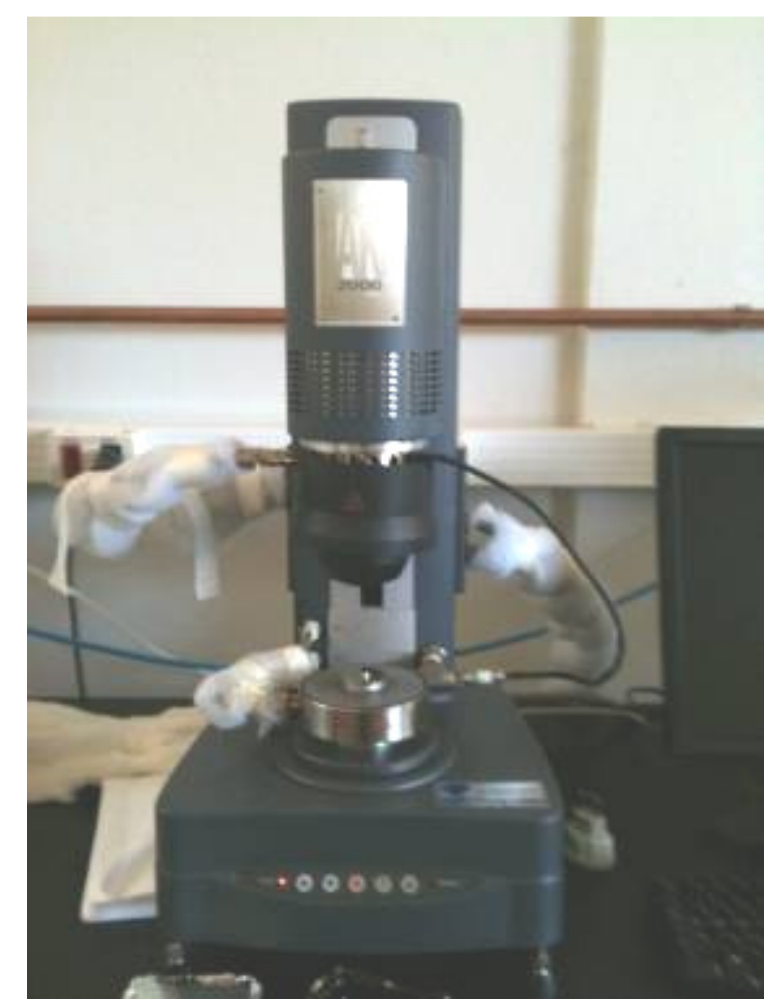

Figura 16 - Reômetro AR-2000ex instalado na EESC - USP

- ensaio de fluência e recuperação do ligante sobre tensão múltipla (MSCR Multiple Stress Creep and Recovery Test), realizado em cinco temperaturas de ensaio entre 52 e $76{ }^{\circ} \mathrm{C}$ e equidistantes de $6{ }^{\circ} \mathrm{C}$ entre si, seguindo $\mathrm{o}$ padrão da classificação dos ligantes asfálticos por grau de desempenho (ASTM D6373, 2007). O ensaio é normatizado pela ASTM D7405/2010a Standard test Method for Multiple Stress Creep and Recovery (MSCR) of Asphalt Binder Using a Dynamic Shear Rheometer. Neste ensaio foi analisado o resíduo envelhecido, segundo norma ASTM D2872/2004 Standard Test Method for Effect of Heat and Air on a Moving Film of Asphalt (Rolling Thin-Film Oven Test). Os ensaios foram duplicados a fim de se controlar as variabilidades, sendo que os resultados finais destas propriedades foram calculados como a média aritmética simples dos valores individuais em cada temperatura e nível de tensão. A Figura 17 mostra a sequência de ensaio de envelhecimento a curto prazo.O ensaio foi realizado nos três ligantes asfálticos designados como CAP-A (PG 94), CAP-B (PG 64) e CAP-C (PG 70). 


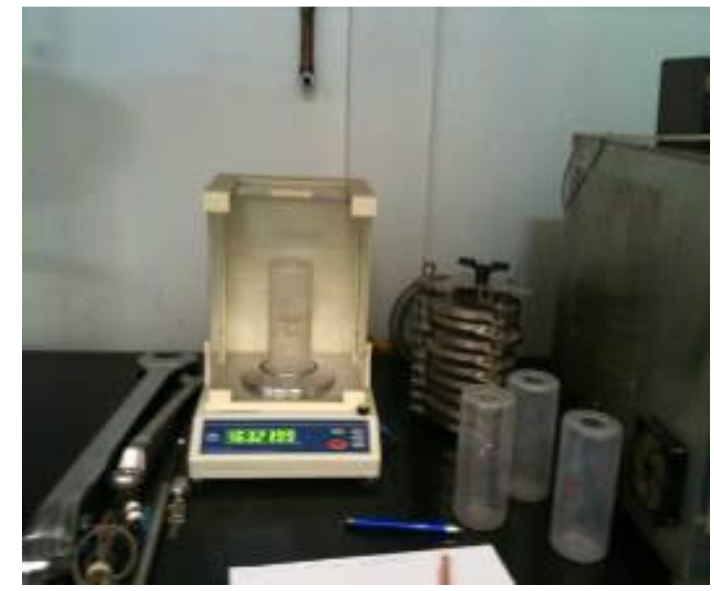

a) Pesagem dos frascos de borossilicato

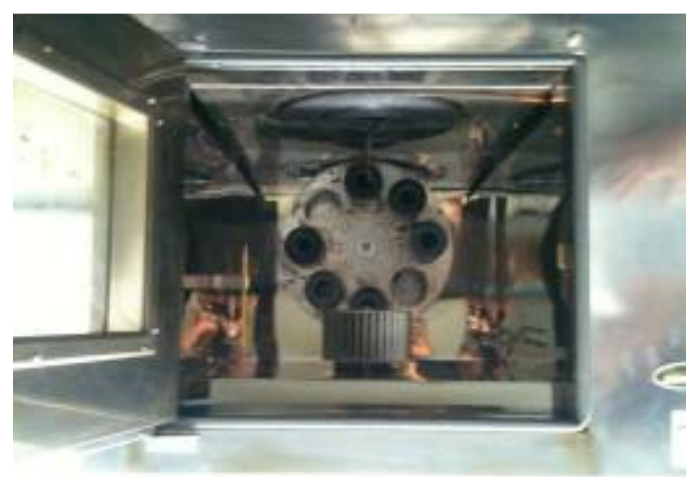

c) Colocação dos frascos com ligante no forno a $163^{\circ} \mathrm{C}$ para início do ensaio de envelhecimento a curto prazo

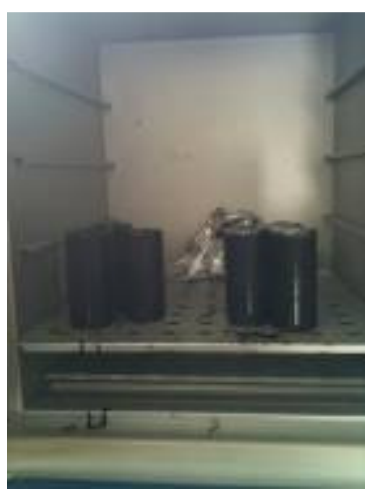

e) Amostras colocadas na estufa após serem retiradas do forno

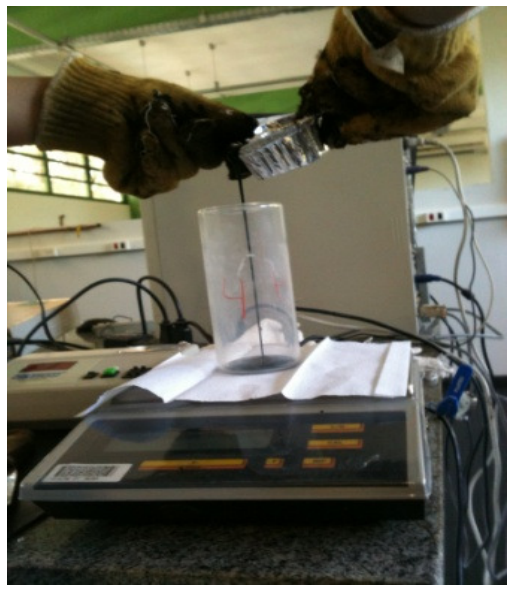

b) Colocação de $35 \mathrm{gr}$ de ligante nos frascos

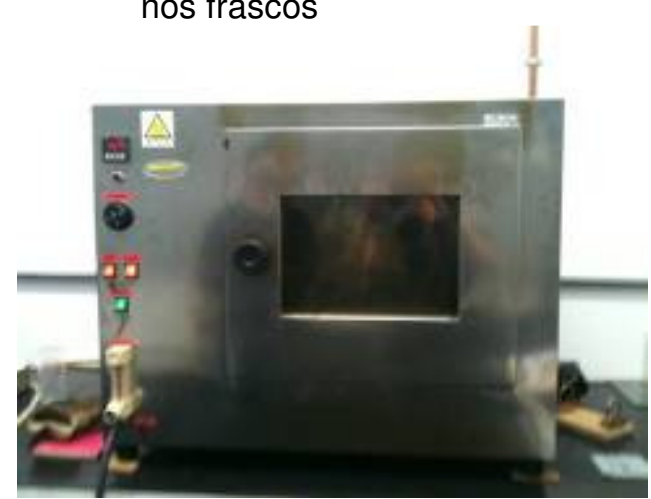

d) Ensaio de envelhecimento a curto prazo, amostras submetidas a jatos de ar e a movimentos circulares no forno

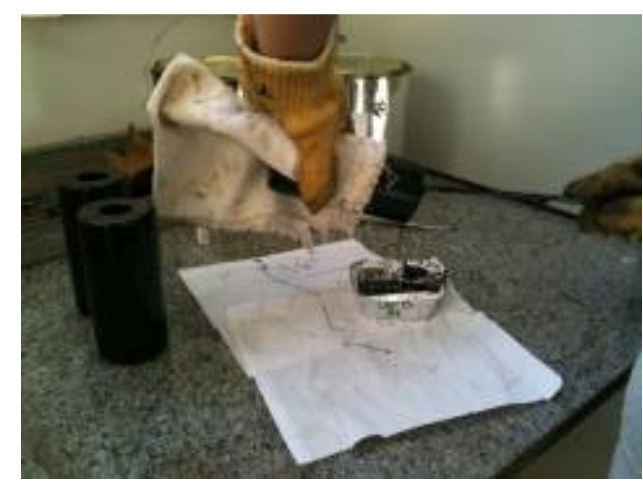

f) Retirada do ligante envelhecido dos frascos com auxílio de espátula

Figura 17 - Sequência de ensaio de envelhecimento a curto prazo RTFOT - EESC-USP

A Tabela 16 mostra os resultados obtidos com a caracterização dos ligantes. 
Tabela 16 - Caracterização dos ligantes utilizados na pesquisa

\begin{tabular}{|c|c|c|c|c|}
\hline CARACTERÍSTICAS & $\begin{array}{l}\text { REFERÊNCIA } \\
\text { NORMATIVA }\end{array}$ & CAP A & CAP B & CAP $30 / 45$ \\
\hline Penetração $\left(100 \mathrm{~g}, 5 \mathrm{~s}, 25^{0} \mathrm{C}\right), \mathrm{dmm}$ & NBR-6576 & 14 & 16 & 33 \\
\hline Ponto de Amolecimento, ${ }^{0} \mathrm{C}$ & NBR-6560 & 75 & 58 & 53 \\
\hline Viscosidade Brookfield a $135{ }^{\circ} \mathrm{C}$ & NBR-15184 & 3000 & 717 & 442 \\
\hline Viscosidade Brookfield a $150{ }^{\circ} \mathrm{C}$ & NBR-15184 & 1170 & 326 & 218 \\
\hline Viscosidade Brookfield a $177^{\circ} \mathrm{C}$ & NBR-15184 & 290 & 105 & 77 \\
\hline Temperatura de Mistura, ${ }^{0} \mathrm{C}$ & Cálculo & 174 a 178 & 163 a 168 & 154 a 159 \\
\hline Temperatura de Compactação, ${ }^{0} \mathrm{C}$ & Cálculo & 161 a 164 & 152 a 156 & 142 a 147 \\
\hline Índice de Suscetibilidade Térmica (IST) & Cálculo & ND & $-1,6$ & $-1,5$ \\
\hline Ponto de Fulgor, ${ }^{0} \mathrm{C}$ & NBR-11341 & ND & ND & ND \\
\hline Densidade relativa a $20 / 4{ }^{\circ} \mathrm{C}$ & NBR-6296 & 1,021 & 1,025 & 1,014 \\
\hline
\end{tabular}

ND - Não Determinado

Os resultados de caracterização dos ligantes demonstram que os CAPs considerados de módulo elevado, CAP A e CAP B, apresentam penetração baixa em relação ao CAP convencional, conforme especificação, assim como alta viscosidade e maiores valores de ponto de amolecimento em comparação com o CAP 30/45. Pode-se observar que apesar do CAP A e CAP B serem denominados duros, com penetrações similares, as demais propriedades são diferentes (viscosidade e ponto de amolecimento). Os CAPs A e B se enquadram também na especificação francesa NF-EN 13924/2006 - Bitumes et liants bitumineuxSpécifications des bitumes routies de grade dur, onde é mencionado que a penetração para ligantes duros deve variar de 10 a $20 \mathrm{dmm}$ com ponto de amolecimento de $60^{\circ} \mathrm{C}$ a $76^{\circ} \mathrm{C}$, ou ainda de 15 a $25 \mathrm{dmm}$ com ponto de amolecimento de $55^{\circ} \mathrm{C}$ a $71^{\circ} \mathrm{C}$. Quanto à viscosidade, a norma francesa não faz nenhuma referência.

No Laboratório de Estradas da Escola de Engenharia de São Carlos- EESC-USP, realizou-se o ensaio de envelhecimento de curto prazo (RTFOT) do ligante e o ensaio de cisalhamento dinâmico para verificação do comportamento reológico dos ligantes asfálticos duros, utilizados na produção das misturas de módulo elevado nessa pesquisa, e do ligante asfáltico convencional. Devido à limitação de tempo, aborda-se neste estudo apenas o comportamento do ligante virgem para avaliação 
do comportamento reológico e verificação do parâmetro $\mathrm{G}^{*} / \operatorname{sen} \delta$ dos ligantes asfálticos em estudo, conforme Tabela 3 da AASHTO ME320 (2009).

Na Figura 18 é apresentado o resultado do parâmetro G*/sen $\delta$ para as diferentes condições de temperaturas avaliadas. A especificação preconiza que na condição de ligante virgem, os CAPs devem apresentar valor superior a $1,0 \mathrm{kPa}$, de forma que para o CAP A essa condição foi atendida a uma temperatura de $94^{\circ} \mathrm{C}$, para o CAP B de $76^{\circ} \mathrm{C}$ e para o CAP $30 / 45$ a uma temperatura de $70^{\circ} \mathrm{C}$.

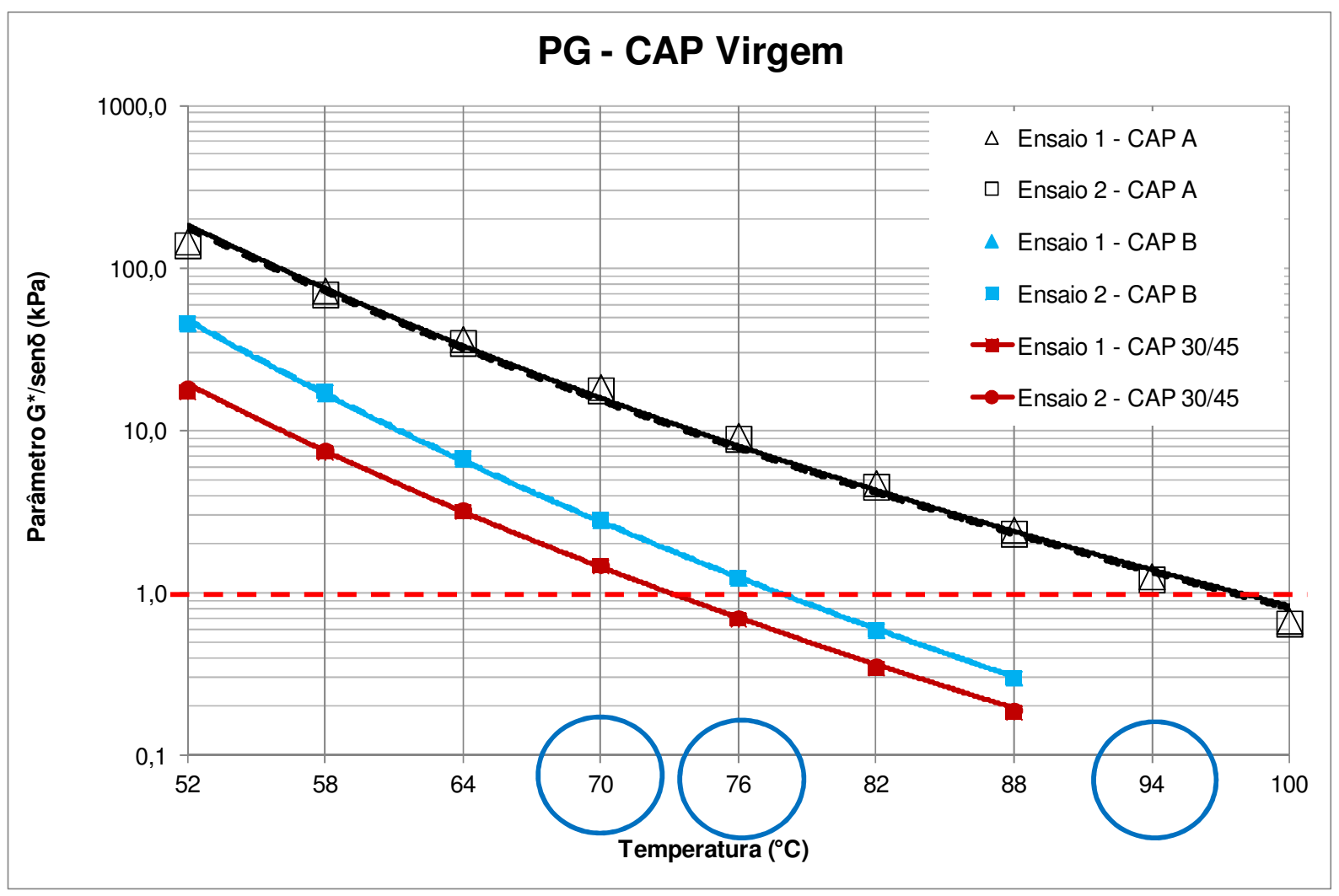

Figura 18 - Parâmetro de PG para ligantes virgens - CAP A, CAP B e CAP 30/45

As Figuras 19 e 20 mostram as características viscoelásticas, $G^{*}$ e $\delta$, respectivamente, dos ligantes de baixa penetração em estudo. A variação no ângulo de fase entre os dois ligantes mostra a diferença entre a parcela elástica e a parcela viscosa dos ligantes duros. O CAP A apresentou-se mais rígido (maior valor de $\mathrm{G}^{*}$ ) e mais elástico (menor valor de $\delta$ ) quando comparado com o CAP B. É importante mencionar que essas afirmativas são válidas considerando-se a caracterização feita no regime viscoelástico linear. 


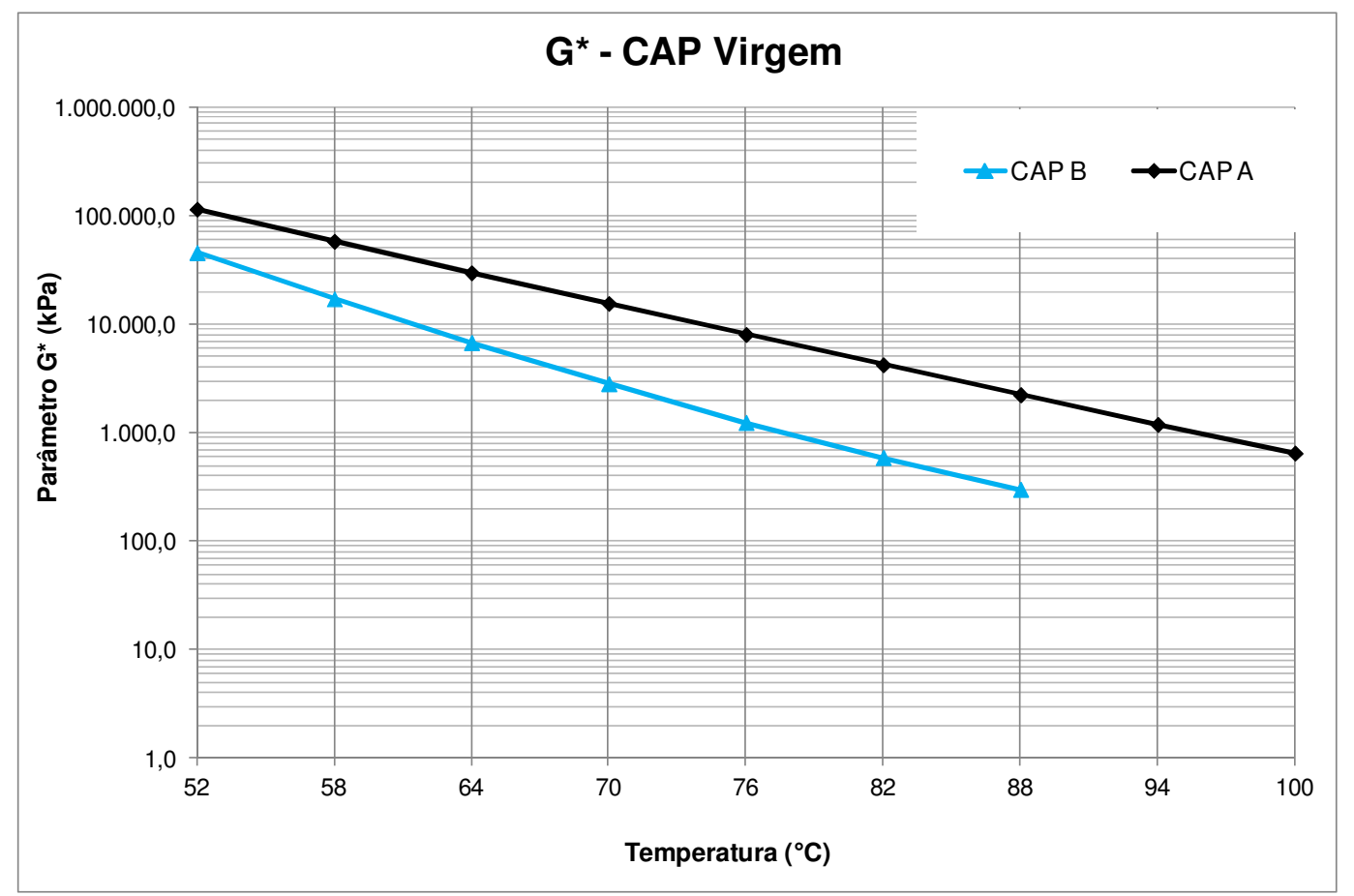

Figura 19 - Valores de G* dos ligantes asfálticos duros (CAP A e CAP B)

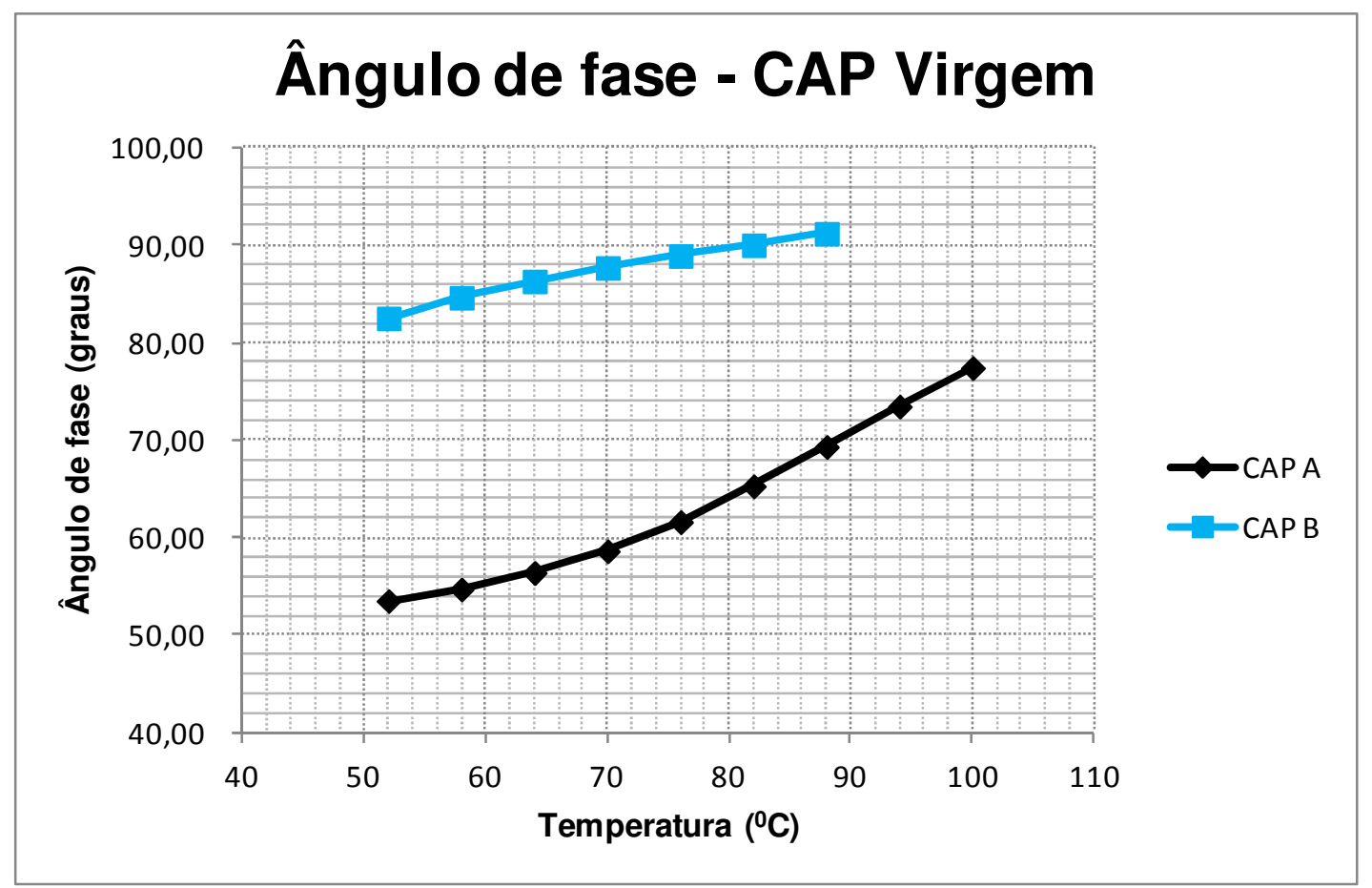

Figura 20 - Ângulos de fase $(\delta)$ dos ligantes asfálticos duros (CAP A e CAP B)

A temperatura que atendeu ao parâmetro $\mathrm{G}^{*} / \operatorname{sen} \delta$ do CAP A na condição virgem foi bastante elevada, estando acima até mesmo da maior temperatura presente na especificação Superpave $\left(88^{\circ} \mathrm{C}\right)$. O valor encontrado para o CAP B apresentou-se 
mais compatível com os resultados de muitos ligantes modificados empregados em misturas de módulo elevado encontrados na literatura.

Procedeu-se o envelhecimento de curto prazo (RTFOT) dos ligantes duros para a realização do ensaio MSCR. Após o envelhecimento foi observada perda de massa das amostras devido ao processo de volatização

Os ensaios de MSCR foram realizados na faixa de temperaturas de ocorrência de deformação permanente em pavimentos asfálticos, ou seja, entre 52 e $76^{\circ} \mathrm{C}$, com incrementos de $6^{\circ} \mathrm{C}$. Uma vez que os orgãos rodoviários americanos recomendam a realização deste ensaio na temperatura alta do PG exigido pelo pavimento. A temperatura de ensaio mais alta foi $76^{\circ} \mathrm{C}$, admitindo que seria a temperatura máxima na faixa de temperaturas típicas de ocorrência de deformação permanente, em pavimentos asfálticos brasileiros. Vale ressaltar que a classificação para nível de tráfego no PG do pavimento é para aplicação em camada de revestimento. Neste estudo, admite-se que essa situação seria reproduzida na camada de base, para análise dos resultados.

Neste ensaio, pode-se avaliar o percentual de recuperação de um ligante quando submetido a uma tensão baixa e a uma tensão alta. O percentual de recuperação (R) é calculado pela razão entre a deformação não-recuperável e a deformação total sofrida pelo ligante asfáltico, em cada ciclo de fluência e recuperação, e a compliância não-recuperável $\left(J_{\text {nr }}\right)$ que é calculada pela razão entre a deformação não-recuperável do ligante asfáltico e a tensão aplicada.

O CAP A é o que suporta o maior tráfego (extramamente pesado) em todas as temperaturas analisadas. Já o CAP B suporta tráfegos gradativamente menores à medida que aumenta a temperatura do pavimento, atingindo o nível pesado $(H)$ a $70^{\circ} \mathrm{C}$ e padrão (S) a $76^{\circ} \mathrm{C}$. O CAP $30 / 45$ atende ao tráfego pesado a $64^{\circ} \mathrm{C}$ e ao padrão a $70^{\circ} \mathrm{C}$, não sendo recomendado para pavimentos que exijam CAPs com $P G$ maior que $70^{\circ} \mathrm{C}$. Os valores de nível de tráfego por temperatura em cada ligante asfáltico está representado na Tabela 17. Em termos de nível de tráfego, seriam então recomendados, do mais para o menos recomendado, os seguintes ligantes asfálticos: A, B e 30/45. 
Tabela 17 - Classificação do ligante asfáltico por nível de tráfego variando a temperatura

\begin{tabular}{c|c|c|c|c|c}
\hline $\begin{array}{c}\text { Ligante } \\
\text { Asfáltico }\end{array}$ & $52{ }^{\circ} \mathrm{C}$ & $58{ }^{\circ} \mathrm{C}$ & $\mathbf{6 4}{ }^{\circ} \mathrm{C}$ & $\mathbf{7 0}{ }^{\circ} \mathrm{C}$ & $\mathbf{7 6}{ }^{\circ} \mathbf{C}$ \\
\hline CAP A & E & E & E & E & E \\
\hline CAP B & E & E & V & H & S \\
\hline CAP 30/45 & E & E & H & S & - \\
\hline
\end{tabular}

O gráfico de percentual de recuperação para os asfaltos de módulo elevado estudados mostra que o CAP A é altamente recuperável quando submetido a uma carga baixa, fato que não se repete quando o mesmo é submetido a uma carga mais alta. Já o CAP B não se mostra recuperável em nenhuma das duas condições de carregamento, fato demonstrado na Figura 21. Conhecendo-se os níveis de tensão, no campo e do ensaio, pode-se em termos práticos, dizer que o CAP A quando submetido a um carregamento imposto pelo tráfego possui capacidade maior de recuperação após o descarregamento, enquanto que o CAP B e o CAP 30/45 é sucetível a esta deformação. O resultado da compliância não recuperável corrobora esse fato, visto que o CAP A possui maior resistência à deformação permanente quando comparado com o CAP B (Figura 22).

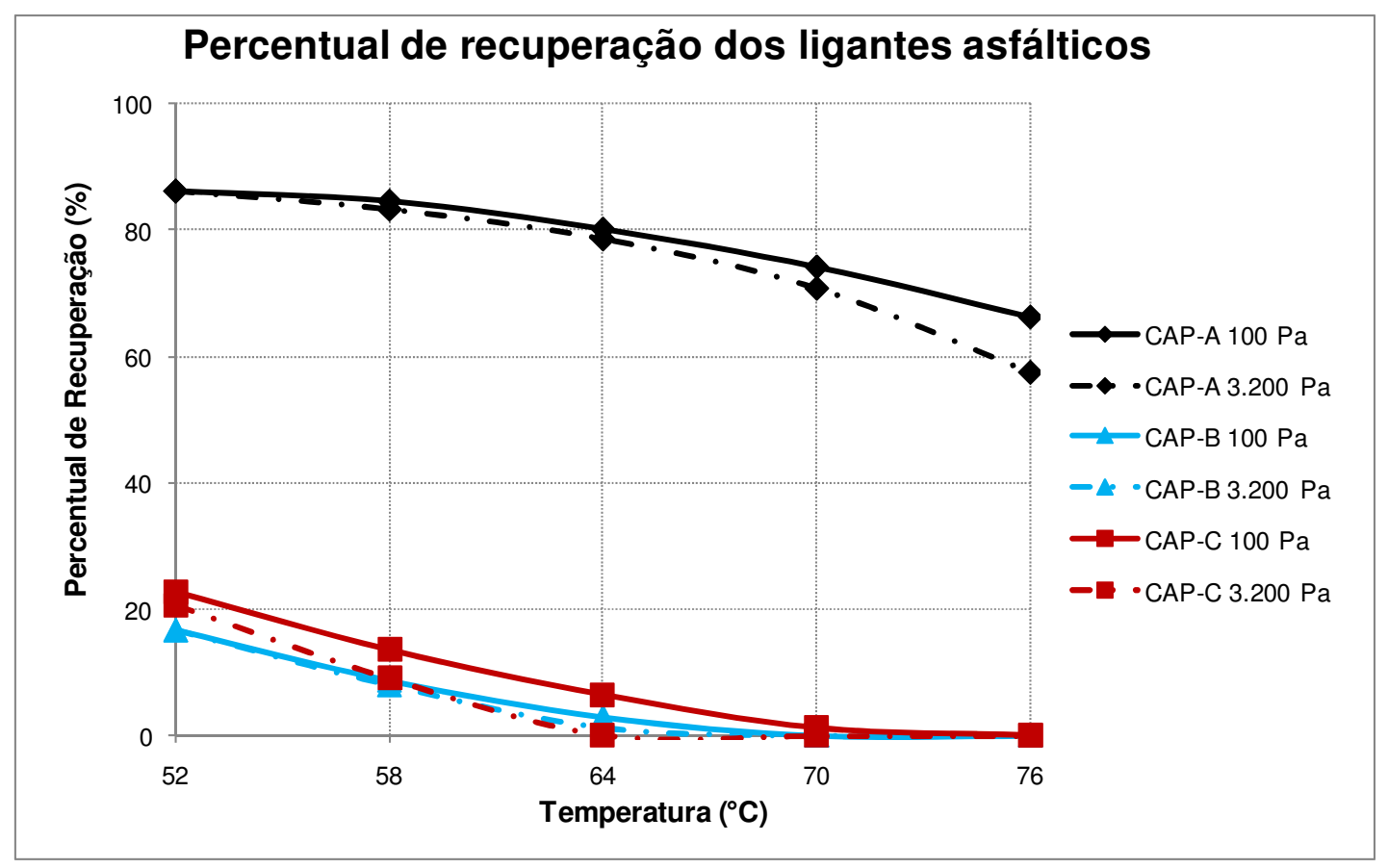

Figura 21 - Gráfico de percentual de recuperação dos ligantes asfálticos 


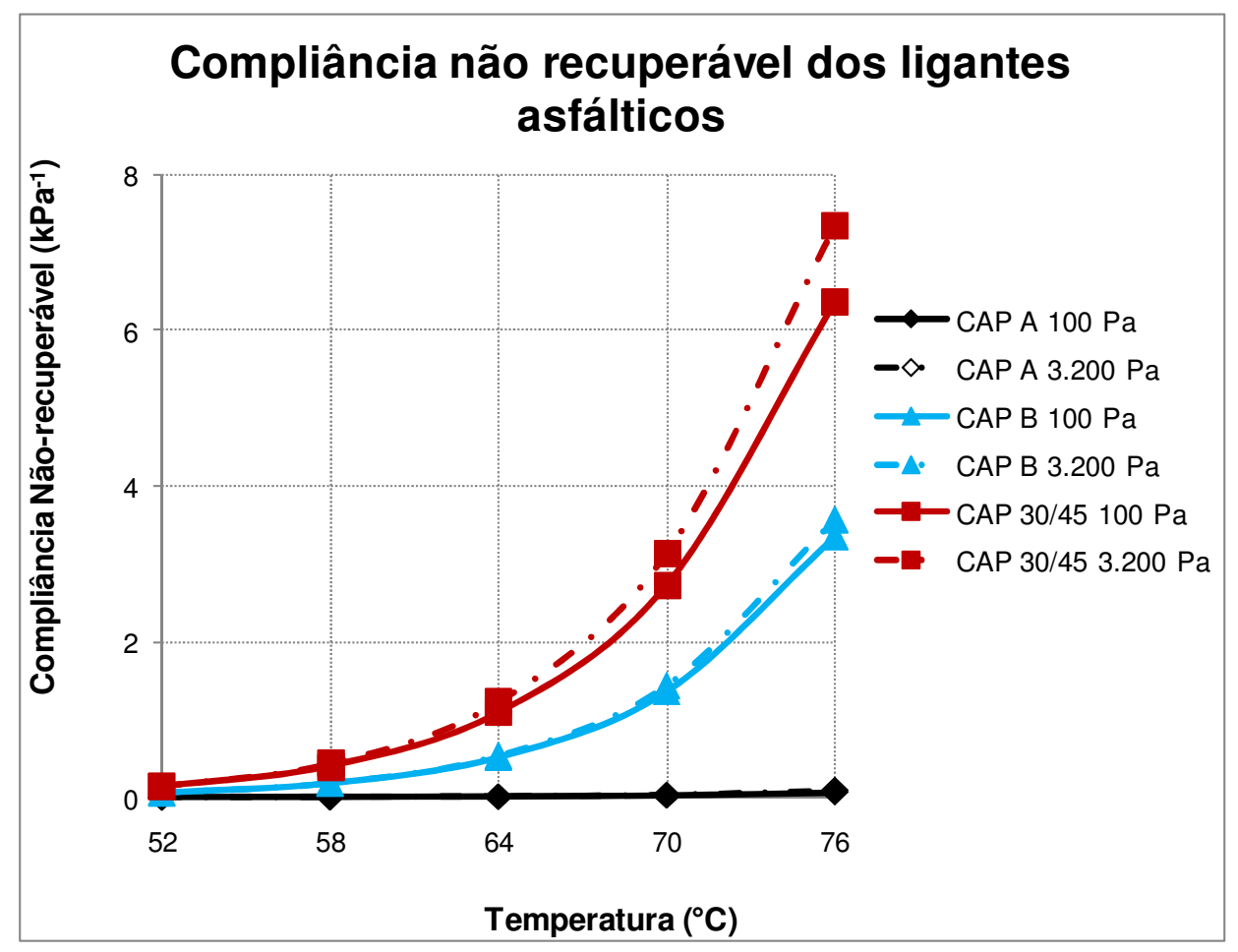

Figura 22 - Gráfico de compliância não recuperável dos ligantes asfálticos

Foi calculada também a diferença entre percentuais não recuperáveis dos CAPs em questão, esta diferença é calculada através da variação do nível de tensão passando de 100Pa para 3.200Pa, onde valores altos de $J_{n r}$ mostram a suscetibilidade do material à deformação permanente em situações de aumento brusco de temperatura e de carregamento elevado não previsto. Um valor menor de $J_{\mathrm{nr}}$ indica que o ligante asfáltico é menos suscetível à deformação permanente em campo ou, em outras palavras, que a contribuição do ligante asfáltico na deformação permanente da mistura asfáltica é menor. Diferentemente do percentual de recuperação, as compliâncias não-recuperáveis do CAP B e do CAP 30/45 apresentam diferenças significativas entre si em todas as temperaturas a 100 e a 3.200 Pa, sendo maiores para o CAP 30/45 e menores para o CAP-B. Esta conclusão pode ser interpretada como uma maior suscetibilidade do CAP 30/45 à deformação permanente de campo em comparação ao CAP B e ao CAP A (Figura 23). 
A Tabela 3 da norma AASHTO M320-09 limita o valor de $J_{n r \text {,diff }}$ em $75 \%$ na temperatura do PG do ligante asfáltico envelhecido a curto prazo, tendo como objetivo limitar a sensibilidade do material a mudanças bruscas no nível de tensão. Como se pode observar na Figura 23, os resultados de $J_{n r \text {,diff }}$ são todos inferiores a $31 \%, 7 \%$ e $16 \%$ para os ligantes asfálticos A, B e 30/45, respectivamente. Admitindo-se que este limite de $75 \%$ é válido também para as temperaturas de 64 , 70 e $76{ }^{\circ} \mathrm{C}$ dos ligantes asfálticos estudados na pesquisa, é possível concluir que os três ligantes asfálticos apresentam uma sensibilidade baixa a variações do nível de tensão.

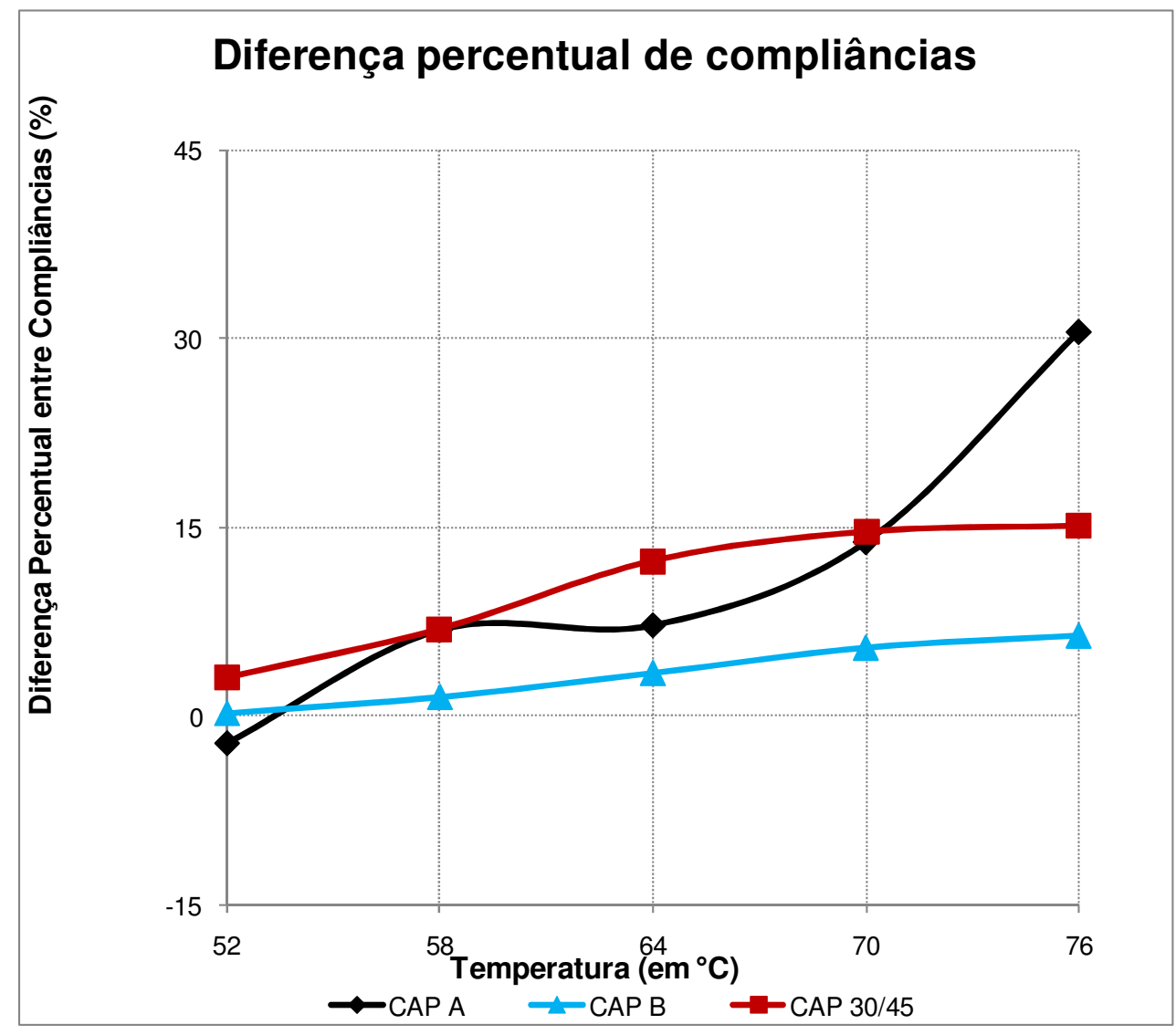

Figura 23 - Diferença percentual de compliâncias (a baixa e alta tensão) 
Este capítulo aborda a granulometria empregada nesta pesquisa, o estudo dos agregados combinados, os tipos de dosagens ensaiadas (Marshall e Superpave) e a verificação da compactação da mistura no compactador giratório Francês. Contempla também os procedimentos e parâmetros de ensaio adotados e seus resultados, além do estudo das misturas de módulo elevado elaboradas com o ligante A e B com relação ao dano por umidade induzida.

\subsection{GRANULOMETRIA}

A faixa de trabalho empregada nesta pesquisa tem como parâmetros estudos anteriores realizados com misturas de módulo elevado, uma vez que a norma francesa não faz referência a uma faixa granulométrica. Decidiu-se procurar reproduzir a curva granulométrica empregada na tese de doutoramento de Villela (2012), que concebeu, acompanhou e monitorou três segmentos de trechos experimentais com base asfáltica de EME na faixa 0/14 francesa. Os resultados foram excelentes e mostraram o bom desempenho desta solução de elevada rigidez. Foram utilizados três tipos de frações: brita 1, pedrisco e pó de pedra para composição da faixa granulométrica de estudo, EME 0/14.

Os agregados foram coletados diretamente na usina em uma única vez nas pilhas de estocagem, transportados para os laboratórios, armazenados e estocados em sacos plásticos impermeáveis e em tambores devidamente identificados. A Figura 24 mostra fotos destas três frações da Pedreira Jambeiro empregadas na composição. 


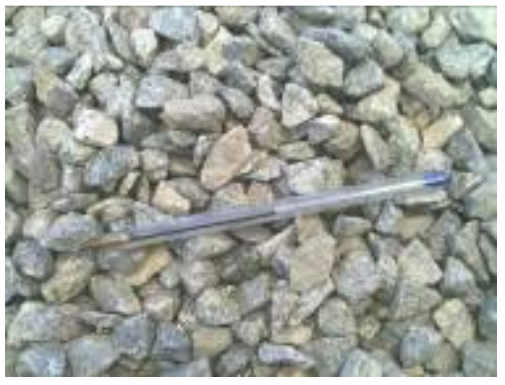

a) Brita 1

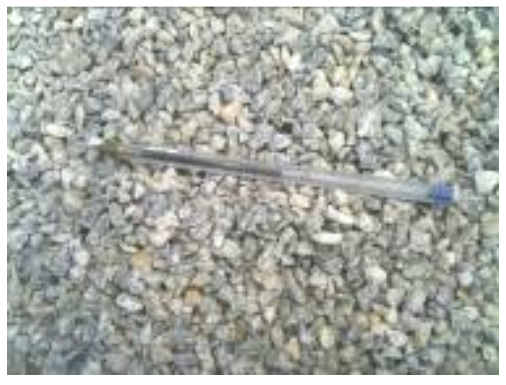

b) Pedrisco

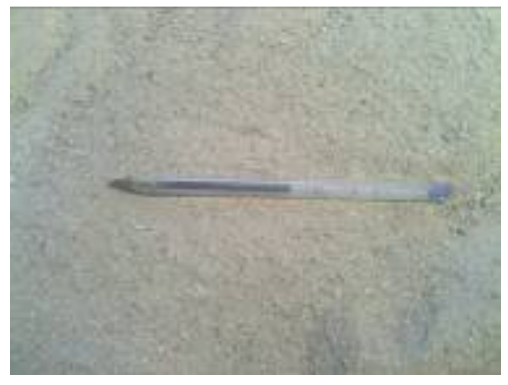

c) Pó de pedra

Figura 24 - Imagem dos agregados utilizados na pesquisa

Para esta pesquisa foram utilizadas as peneiras de malhas: $19,10 \mathrm{~mm}(3 / 4$ "); $16,00 \mathrm{~mm}$ (5,8"); $12,50 \mathrm{~mm}$ (1/2"); 9,50mm (3/8"); 6,40mm (1/4");4,76mm ( $\left.\mathrm{n}^{0} 4\right)$; $2,00 \mathrm{~mm}\left(\mathrm{n}^{\circ} 10\right) ; 0,42 \mathrm{~mm}\left(\mathrm{n}^{\circ} 40\right) ; 0,18 \mathrm{~mm}\left(\mathrm{n}^{0} 80\right) ; 0,075 \mathrm{~mm}\left(\mathrm{n}^{0} 200\right)$ para o controle granulométrico.

A mistura asfáltica criada para a realização desta pesquisa apresenta características desejadas para atender a uma mistura de base de módulo elevado, ou seja, apresenta uma faixa contínua e bem graduada, com objetivo de que os agregados miúdos ocupem os vazios criados no arranjo dos agregados graúdos. Este arranjo entre materiais quando bem compactados oferece maior resistência.

A composição da mistura seca da mistura em estudo é dada pela proporção:15\% Brita $1 ; 28 \%$ Pó de Pedra; $57 \%$ Pedrisco. A Tabela 18 apresenta as composições da faixa empregada e a Figura 25 representa graficamente a curva granulométrica desta pesquisa.

Tabela 18 - Composição granulométrica da mistura em estudo

\begin{tabular}{c|c|c|c|c|c}
\hline \multicolumn{5}{c}{ GRANULOMETRIA DA MISTURA DOS AGREGADOS - EME 0/14 - FAIXA FRANCESA } \\
\hline PENEIRA & $\mathrm{mm}$ & OBTIDO & LIMITES & \multicolumn{2}{c}{ EME 0/14 - FAIXA FRANCESA } \\
\hline $3 / 4 "$ & 19,10 & 99 & \pm 7 & 100 & 100 \\
\hline $5 / 8 "$ & 16,00 & 98 & \pm 7 & 99 & 100 \\
\hline $1 / 2 "$ & 12,50 & 93 & \pm 7 & 95 & 99 \\
\hline $3 / 8 "$ & 9,50 & 89 & \pm 7 & 87 & 89 \\
\hline $1 / 4 "$ & 6,40 & 70 & \pm 5 & 73 & 77 \\
\hline № 4 & 4,76 & 60 & \pm 5 & 62 & 66 \\
\hline № 10 & 2,00 & 41 & \pm 5 & 35 & 40 \\
\hline № 40 & 0,42 & 23 & \pm 3 & 14 & 19 \\
\hline № 200 & 0,075 & 8,0 & \pm 2 & 9 & 13 \\
\hline
\end{tabular}




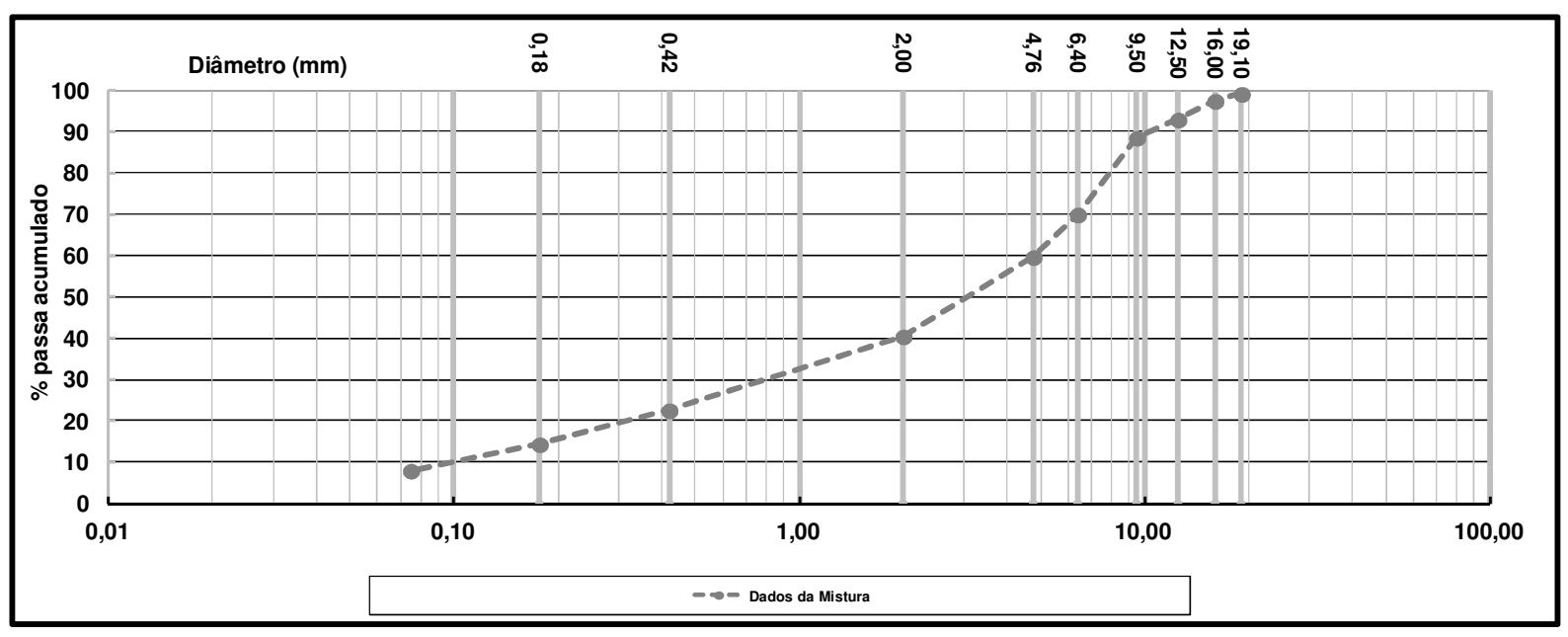

Figura 25 - Curva granulométrica empregada na pesquisa

\subsection{VERIFICAÇÃO DOS AGREGADOS COMBINADOS PELO MÉTODO BAILEY}

A avaliação dos agregados combinados pelo Método Bailey foi realizada e comparada com valores limites estabelecidos por VAVRIK et al.(2002).

O primeiro passo foi a determinação das peneiras de controle.

Peneira de Controle Primário - PCS (Primary Control Sieve)

Peneira de Controle Secundário - SCS (Secondary Control Sieve)

Peneira de Controle Terciário - TCS (Tertiary Control Sieve)

Avaliação da fração graúda (peneira média) - HS (Half Sieve)

O tamanho nominal máximo do agregado (NMAS - Nominal Maximum Particle Size) é utilizado para cálculo dos parâmetros da mistura de agregados combinados para análise do material através do Método Bailey.

Para determinação das peneiras de controle são realizados os seguintes cálculos:

$$
\begin{aligned}
& \mathrm{PCS}=\text { NMAS } \times 0,22 \\
& \mathrm{SCS}=\mathrm{PCS} \times 0,22
\end{aligned}
$$




$$
\mathrm{TCS}=\operatorname{SCS} \times 0,22 \text { (6) }
$$

Onde o coeficiente de 0,22 foi determinado a partir de uma análise em duas e três dimensões do arranjo de agregados de diferentes formas (VAVRIK et al., 2002).

A avaliação da mistura de agregados combinada se dá pela aplicação de equações para determinação de parâmetros de:

Proporção de agregado graúdo - CA (Coarse Aggregate Ratio)

Proporção do agregado miúdo - FAc (Fine Aggregate Coarse Ratio)

Proporção miúda do agregado miúdo - FAf (Fine Aggregate Fien Ratio)

Estes parâmetros são determinados por meio das equações:

$$
\text { Proporção } \mathrm{CA}=\frac{\% \text { passante na HS }-\% \text { passante na PCS }}{100-\% \text { passante na HS }}
$$

$$
\begin{aligned}
& \text { Proporção } \mathrm{Fac}=\frac{\% \text { passante na SCS }}{\% \text { passante na PCS }} \\
& \text { Proporção Faf }=\frac{\% \text { passante na TCS }}{\% \text { passante na SCS }}
\end{aligned}
$$

Os limites estabelecidos por Vavrik et al. (2002) estão representados na Tabela19.

Tabela 19 - Limites para parâmetros de misturas de agregados combinados pelo Método Bailey

\begin{tabular}{l|c|c|c|c|c|c}
\hline \multicolumn{7}{c}{ TAMANHO NOMINAL MÁXIMO (mm) } \\
\hline & 37,5 & 25 & 19 & 12,5 & 9,5 & 4,75 \\
\hline Proporção CA & $0,80-0,95$ & $0,70-0,85$ & $0,60-0,75$ & $0,50-0,65$ & $0,40-0,55$ & $0,30-0,45$ \\
\hline Proporção FAc & $0,35-0,50$ & $0,35-0,50$ & $0,35-0,50$ & $0,35-0,50$ & $0,35-0,50$ & $0,35-0,50$ \\
\hline Proporção FAf & $0,35-0,50$ & $0,35-0,50$ & $0,35-0,50$ & $0,35-0,50$ & $0,35-0,50$ & $0,35-0,50$ \\
\hline
\end{tabular}

O procedimento de seleção e caracterização do agregado pelo Método Bailey, buscou avaliar as condições de intertravamento da estrutura pétrea formada pela mistura de agregados. Como resultado desta análise, obtêm-se a delimitação das peneiras de controle e também o estudo dos agregados combinados. As Tabelas 20 e 21 mostram os resultados desta verificação. 
Tabela 20 - Peneiras de controle encontradas para a mistura dos agregados combinados para análise pelo Método Bailey

\begin{tabular}{|c|c|c|}
\hline \multirow{2}{*}{\multicolumn{2}{|c|}{ PARÂMETROS }} & \multirow{2}{*}{$\begin{array}{l}\text { PENEIRAS DE CONTROLE } \\
\text { Peneiras padrão }(\mathrm{mm})\end{array}$} \\
\hline & & \\
\hline Peneira de Controle Primário & PCS & 2,00 \\
\hline Peneira de Controle Secundário & SCS & 0,42 \\
\hline Peneira de Controle Terciário & TCS & 0,08 \\
\hline Avaliação da fração graúda (peneira média) & HS & 4,76 \\
\hline
\end{tabular}

Tabela 21 - Valores encontrados para a análise da mistura de agregados pelo Método Bailey

\begin{tabular}{l|l|c}
\hline \multicolumn{2}{c}{ ANÁLISE DOS AGREGADOS COMBINADOS } & VALORES \\
\hline Proporção de agregado graúdo & CA & 0,48 \\
\hline Proporção graúda do agregado miúdo & FAc & 0,56 \\
\hline Proporção miúda do agregado miúdo & FAf & 0,35 \\
\hline
\end{tabular}

A proporção de CA é o dado mais importante da mistura, pois indica parâmetros de comportamento de compactação desta mistura de agregados, onde valores baixos de CA indicam que a estrutura possui uma alta compactação de agregados miúdos. Isto remete a uma estrutura forte, uma vez que no método Bailey o esqueleto pétreo é analisado com base nos agregados graúdos e nos agregados miúdos, sendo este os agregados miúdos, os grãos, que proporcionam a interação dos maiores grãos com os menores ocupando os vazios existentes entre eles e ainda deixando espaço para o asfalto. Vale salientar que misturas com valores de $\mathrm{CA}$ abaixo dos recomendados podem apresentar problemas de segregação enquanto que misturas com valores de CA acima do recomendado podem apresentar problemas de compactação. Os valores de FAc acima do recomendado indicam necessidade de maior compactação dos grãos miúdos. Sob o ponto de vista estrutural misturas com FAc acima dos valores recomendados podem ser consideradas não adequadas, enquanto que misturas com FAc abaixo do recomendado podem apresentar problemas de instabilidade e compactação. Valores de FAc abaixo do recomendado indicam uma graduação não uniforme. Os valores recomendados podem ser consultados na Tabela 19. 
Os valores de FAf são utilizados como parâmetros para avaliar o comportamento da compactação para a fração miúda da mistura. Os valores de VAM (vazios agregado mineral) podem aumentar com a redução do FAf.

Os resultados apresentados mostram valores de CA $(0,48)$ dentro do intervalo recomendado para tamanho máximo nominal de $9,5 \mathrm{~mm}$ por Vavrik (2002). Para CA, os valores recomendados variam de 0,40 a 0,55 . Os valores de $\operatorname{FAc}(0,56)$ encontram-se pouco acima do valor recomendado, excedendo-se em 0,06 o limite superior (valores recomendados variando de 0,35 a 0,50), logo é indicado uma maior compactação dos agregados miúdos da mistura. O valor de FAf encontra-se no limite inferior dos valores recomendados, ou seja valor de 0,35 (valores recomendados variando de 0,35 a 0,50 ).

\subsection{DOSAGENS}

\subsubsection{Dosagem Marshall}

Os ensaios de dosagem Marshall foram realizados nos dois laboratórios envolvidos nesta pesquisa. Estabeleceu-se o teor de projeto através do procedimento apontado na norma brasileira NBR 12891/1993 - Dosagem de misturas betuminosas pelo método Marshall - Procedimento. Os agregados devem ser colocados na estufa e, posteriormente, os agregados e o ligante asfáltico devem ser misturados por meio de um misturador. A compactação dos corpos-de-prova é feita em um compactador mecânico, munido de soquete, que cai sobre a amostra de mistura asfáltica a partir de uma altura fixa, em queda livre. A energia utilizada para esta compactação corresponde a 75 golpes por face do corpo-de-prova. Os CPs moldados ficam em 
repouso por 24h e somente após este período são extraídos de seus moldes. Foram moldados cerca de $20 \mathrm{CPs}$ para cada mistura estudada, tendo sido utilizados para realização de ensaios mecânicos para determinação da resistência à tração, do módulo de resiliência e da vida de fadiga por compressão diametral. A Figura 26 mostra os equipamentos utilizados para elaboração da mistura para a compactação Marshall.

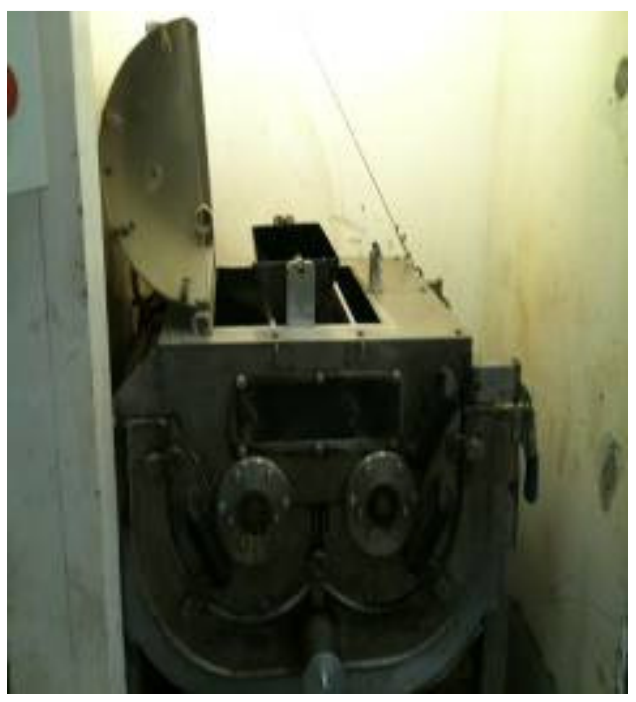

a) Equipamento para homogeneização da mistura para ensaios- misturadora

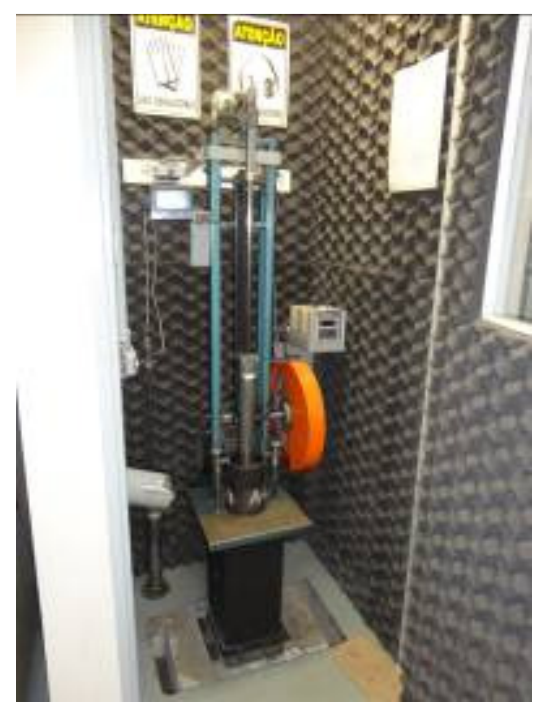

b) Compactador Marshall

Figura 26 - Dosagem Marshall, LTP-USP

Com a granulometria estudada confeccionaram-se corpos-de-prova por meio do compactador Marshall para obtenção de massa específica aparente e características volumétricas da mistura (porcentagem de vazios de ar (Va); porcentagem de vazios no agregado mineral (VAM). Misturas de módulo elevado devem apresentar volume de vazios inferiores a $6 \%$.

A dosagem Marshall foi realizada com os três tipos de CAP da pesquisa, CAP A, CAP B e CAP convencional 30/45. O teor de projeto obtido nesta dosagem foi replicado para elaboração de outros corpos-de-prova para os ensaios mecânicos. Os resultados da dosagem Marshall podem ser apresentados na Tabela 22. 
Tabela 22 - Resumo dos resultados obtidos com a dosagem Marshall para as misturas asfálticas estudadas

\begin{tabular}{l|c|c|c|c|c|c}
\hline \multicolumn{7}{|c}{ DOSAGEM MARSHALL - PARÂMETROS DA MISTURA } \\
\hline \multirow{3}{*}{ CAP } & $\%$ & \multicolumn{2}{|c|}{$\begin{array}{c}\text { DOSAGEM DE CONCRETO } \\
\text { ASFÁLTICO ( CA })\end{array}$} & $\%$ & $\%$ & $\%$ \\
\cline { 2 - 7 } & Asfalto & $\begin{array}{c}\text { Aparente } \\
\left(\mathbf{g} / \mathbf{c m}^{3}\right)\end{array}$ & $\begin{array}{c}\text { Máx. Da Mistura } \\
\left(\mathbf{g} / \mathbf{c m}^{3}\right)\end{array}$ & Va & VAM & VCA \\
\hline CAP A & $5,5 \%$ & 2,354 & 2,446 & $3,7 \%$ & $15,5 \%$ & $75,8 \%$ \\
\hline CAP B & $4,8 \%$ & 2,372 & 2,463 & $3,7 \%$ & $14,2 \%$ & $73,9 \%$ \\
\hline CAP 30/45 & $4,8 \%$ & 2,363 & 2,460 & $4,0 \%$ & $14,5 \%$ & $72,7 \%$ \\
\hline
\end{tabular}

\subsubsection{Dosagem Superpave}

Estabeleceu-se, em um segundo momento, o teor de projeto através do procedimento SUPERPAVE. Os corpos-de-prova são compactados em equipamento giratório por amassamento e o número de giros considerados foi de 100 ( $\mathrm{N}$ de projeto), recomendado para rodovias com médio/alto volume de tráfego. Os ensaios de dosagem Superpave foram realizados no Centro de Pesquisas Rodoviárias- CPR NovaDutra. Foram adotados quatro teores iniciais de moldagem dos corpos-deprova $(4,0 \% ; 4,5 \% ; 5,0 \%$ e $5,5 \%)$. Para determinação do teor ótimo de projeto. Neste processo de dosagem, a mistura é compactada por amassamento até o $\mathrm{N}$ de projeto, diferentemente do método Marshall, onde a compactação é realizada por impacto. Os CPs foram elaborados em moldes na dimensão de diâmetro de $150 \mathrm{~mm}$ e altura de $100 \mathrm{~mm}$. Foram moldados dois CPs para cada teor definido. A Figura 27 mostra sequência do ensaio de dosagem pelo procedimento SUPERPAVE. 


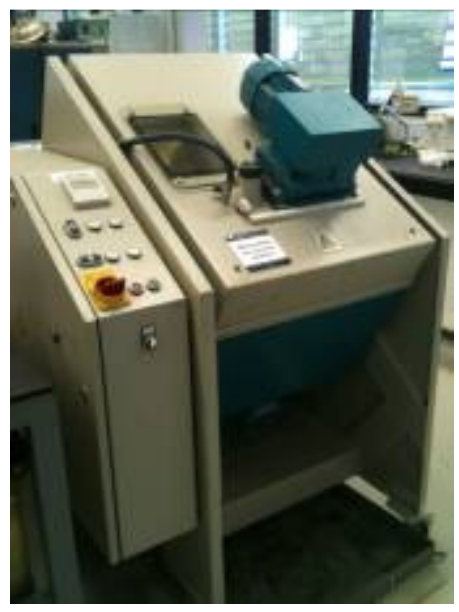

a) Misturadora utilizada para moldagem de CPs (diâmetro de $150 \mathrm{~mm}$ aproximadamente $6,5 \mathrm{~kg}$ de massa/CP)

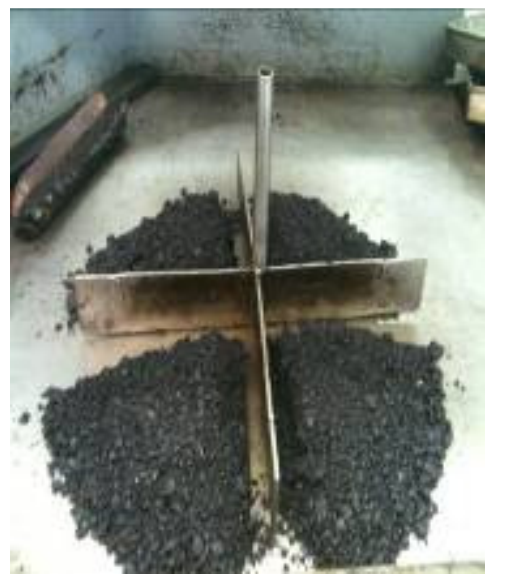

d) Material quarteado, as extremidades opostas serão colocadas moldagem dos CPS

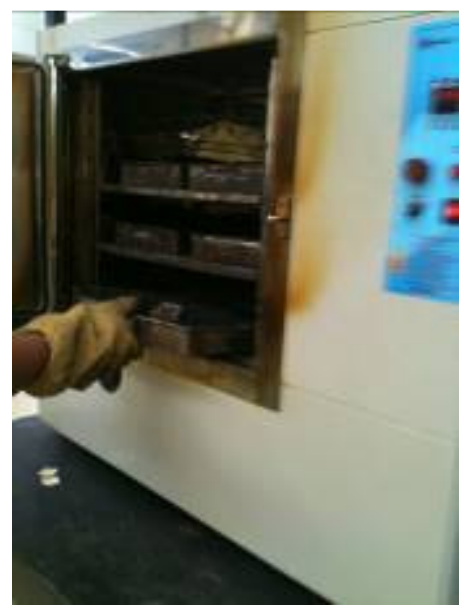

b) Retirada da mistura da estufa

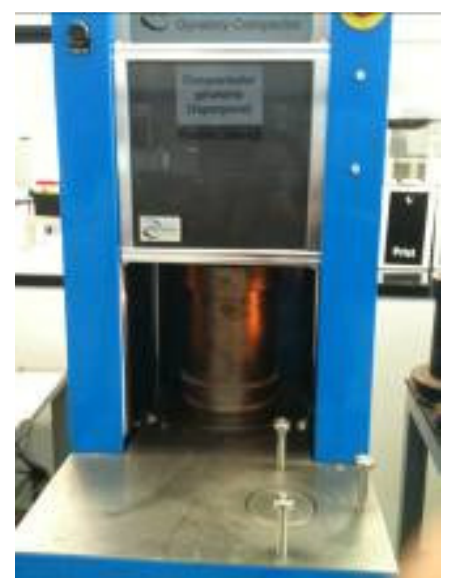

e) Colocação do molde com a mistura asfáltica no compactador por amassamento Superpave

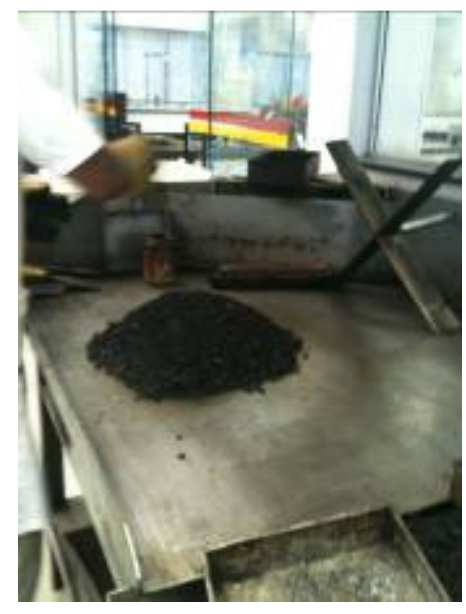

c) Colocação da mistura em mesa metálica para quarteamento do material

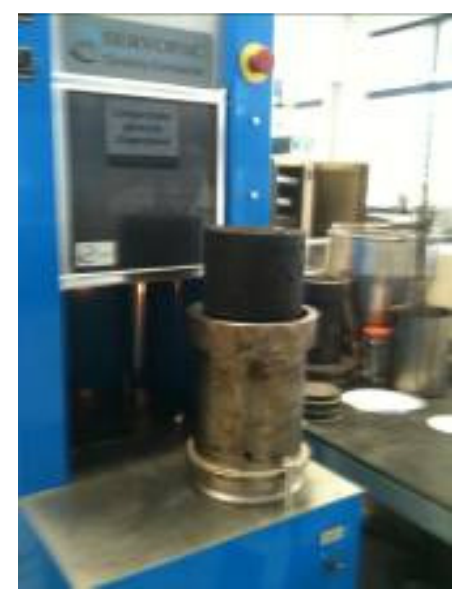

f) Retirada do molde após término de compactação

\section{Figura 27 - Procedimento de dosagem Superpave, CPR-NovaDutra}

O resultado desta dosagem apresentou valores bem próximos aos teores ótimos obtidos na dosagem Marshall. Conforme referência normativa o teor de projeto obtido pela dosagem Superpave foi determinado através da delimitação do volume de vazios de $4 \%$. Estes resultados estão apresentados na Tabela 23. O CAP de módulo elevado $\mathrm{A}$ apresentou teor de projeto resultante da dosagem Superpave no valor de $5,3 \%$ enquanto que o CAP de módulo elevado $B$ apresentou teor de projeto resultante de $4,5 \%$ e o CAP convencional apresentou um teor de projeto de $4,6 \%$, ou 
seja, pouca variação $(0,2 ; 0,3$ e $0,2 \%)$ com os teores de projetos obtidos pela dosagem Marshall de 5,5\%, 4,8\% e 4,8\%, respectivamente. A Figura 28 mostra a representação gráfica do resultado da dosagem Superpave para as misturas em estudo.

Tabela 23 - Resultado da dosagem Superpave paras misturas asfálticas estudadas

\begin{tabular}{c|c|c|c}
\hline \multirow{2}{*}{ CAP } & $\%$ & \multirow{2}{*}{$\mathbf{N}^{0}$ Giros de } \\
projeto & Vazios \\
\cline { 2 - 2 } & Asfalto & 100 & $4 \%$ \\
\hline CAP A & 5,3 & 100 & $4 \%$ \\
\hline CAP B & 4,5 & 100 & $4 \%$ \\
\hline CAP 30/45 & 4,6 & & \\
\hline
\end{tabular}

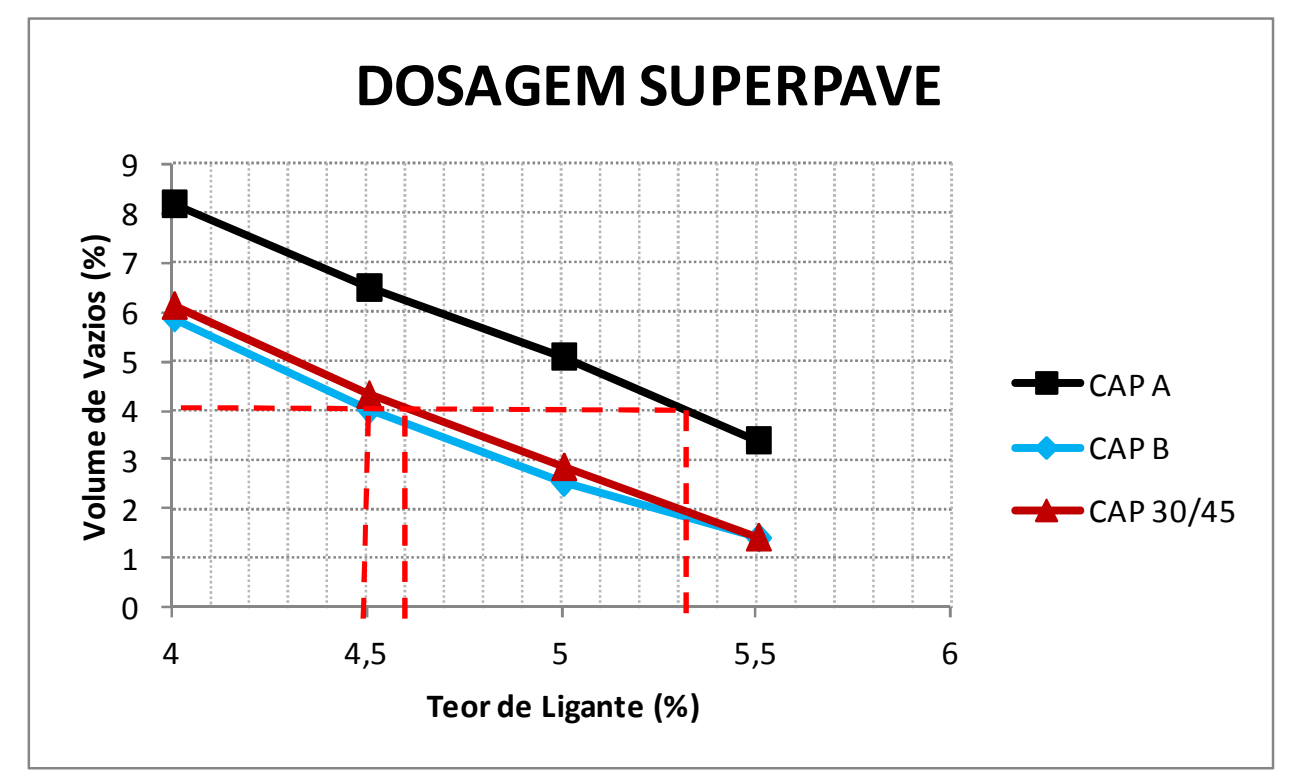

Figura 28 - Gráficos com resultados da dosagem Superpave para as misturas asfálticas estudadas

\subsubsection{Compactação no compactador giratório francês}


Após a definição do teor de projeto da mistura proveniente da dosagem Marshall, estudou-se o processo de compactação no compactador giratório Francês a PCG no Laboratório de Tecnologia de Pavimentação - LTP USP, para avaliar se a mistura atende ou não os parâmetros de vazios para 100 ciclos, exigidos na norma francesa (vazios <6\% para 100 giros) (NF P 98-252, 1999a). A Figura 29 ilustra parte do procedimento. Optou-se por realizar este ensaio com os teores de projeto Marshall por tratar-se do método de dosagem de misturas asfálticas mais utilizado no Brasil.

Para averiguar os vazios na compactação através do compactador giratório francês, foram moldados três CP's para o teor de projeto Marshall do CAP A e dois CP's para o teor de projeto Marshall para o CAP B, pois houve perda de massa da mistura preparada durante o ensaio, inviabilizando a compactação do terceiro $\mathrm{CP}$. $\mathrm{O}$ valor encontrado de volume de vazios para os dois CAPs de baixa penetração desta pesquisa foi inferior a $6 \%$ para 100 giros. Estes valores podem ser observados na Tabela 24. Os resultados encontrados para volume de vazios de cada mistura foram de $4,1 \%$ para a mistura com CAP A e 5,1\% para o CAP B. As Figuras 30 e 31 mostram o volume de vazios em função do número de ciclos aplicados no compactador (PCG). 


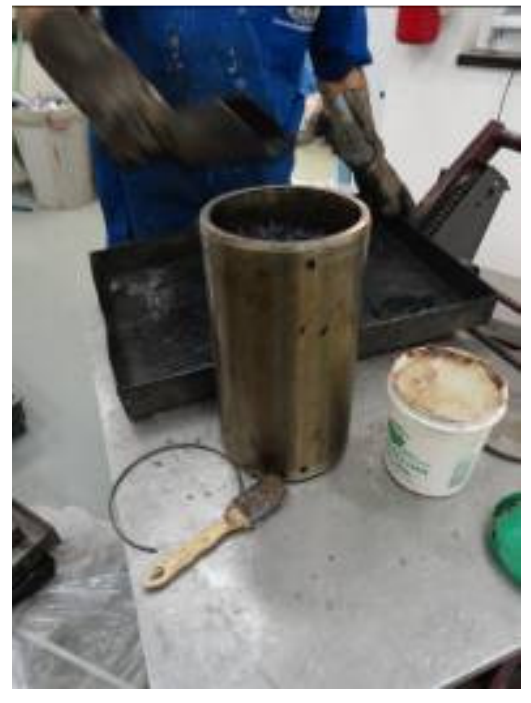

a) Preparo da mistura em cilindro metálico com diâmetro de $150 \mathrm{~mm}$ revestido com vaselina

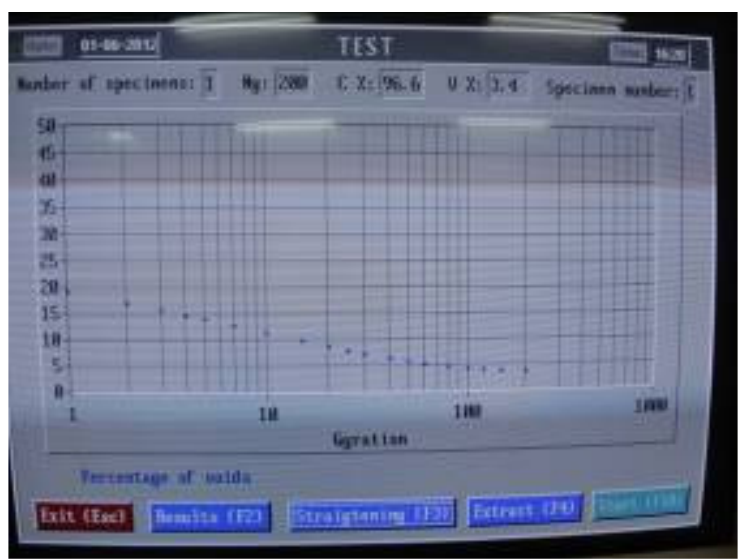

C) Tela do andamento do ensaio no Software da PCG, gráfico com a evolução do ensaio vazios $\times n^{\circ}$ de ciclos

Figura 29 - Etapas do processo de compactação no compactador giratório francês - PCG

Tabela 24 - Resultado da compactação das misturas de módulo elevado estudadas na PCG

\begin{tabular}{c|c|c|c}
\hline & CICLOS & $\mathbf{1 0 0}$ & $\mathbf{2 0 0}$ \\
\hline CAP A & MÉDIA (V\%/ Va\%) & 4,1 & 3,4 \\
\hline & DP & 0,06 & 0,06 \\
\hline CAP B & MÉDIA (V\%/ Va\%) & 5,1 & 3,6 \\
\hline & DP & 0,28 & 0,28 \\
\hline
\end{tabular}

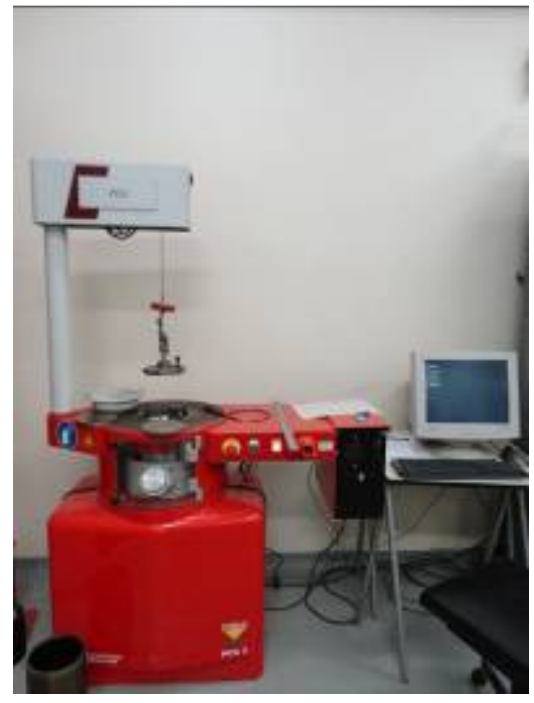

b) Compactador Giratório Francês, PCG com o cilindro já inserido para início do ensaio de compactação

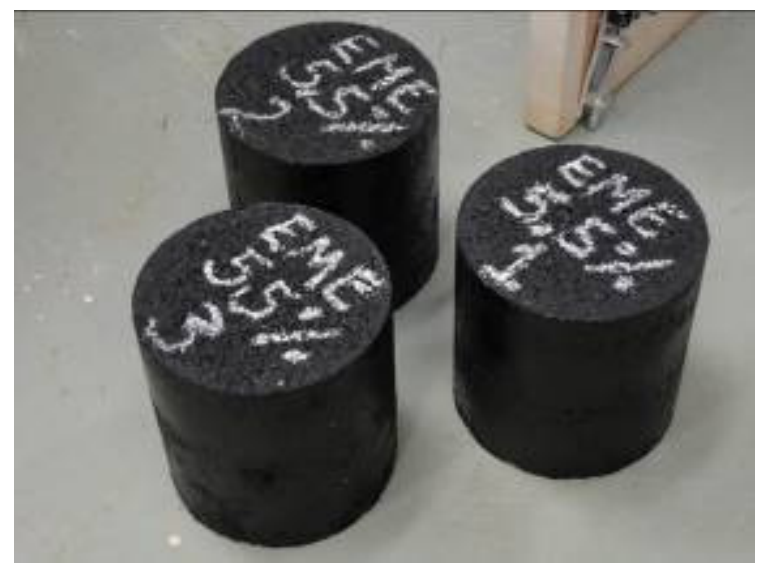

e) Corpos de prova resultantes do ensaio no compactador giratório Francês 


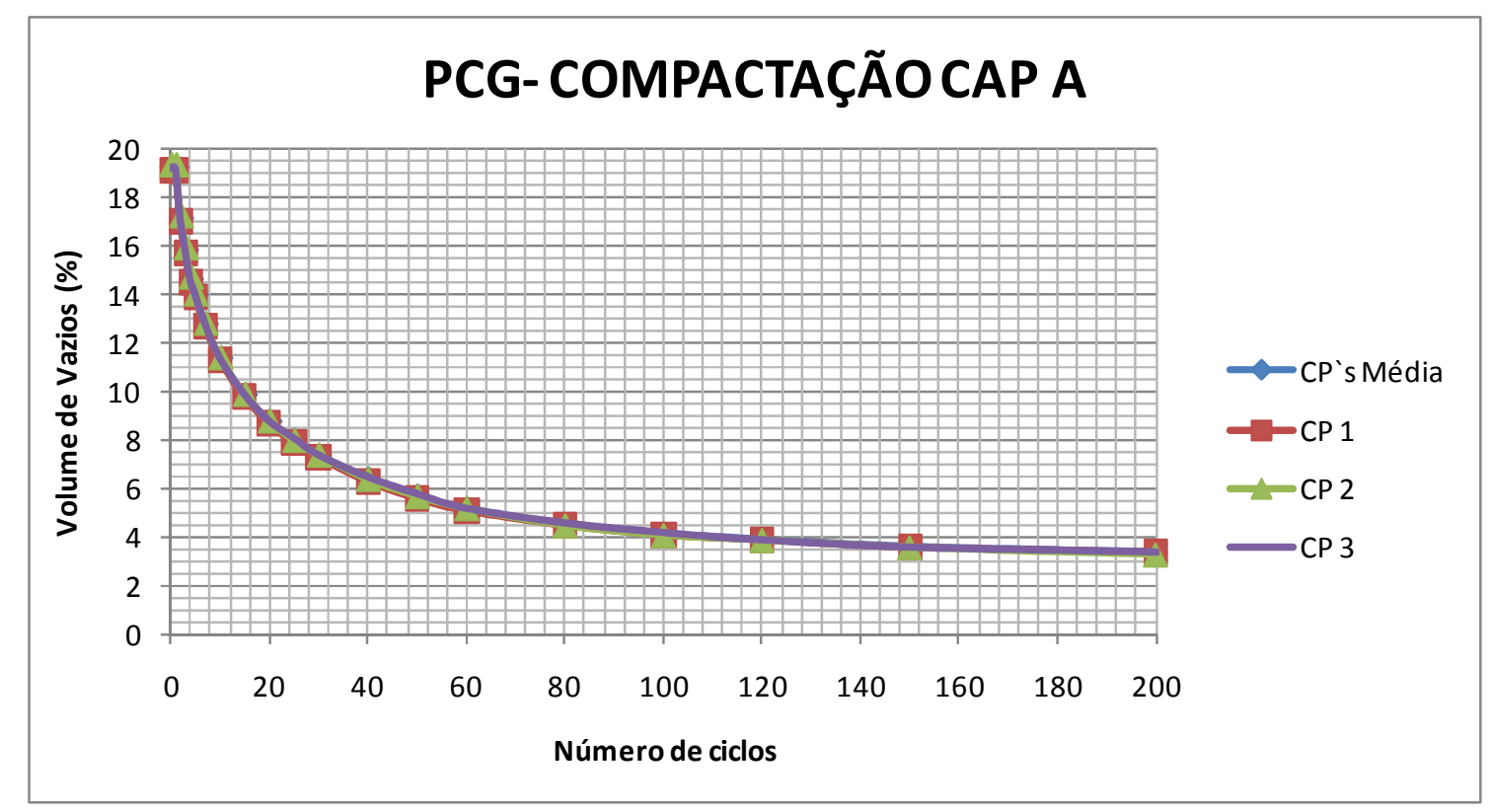

Figura 30 - Gráfico da compactação da mistura de módulo elevado com CAP A - PCG

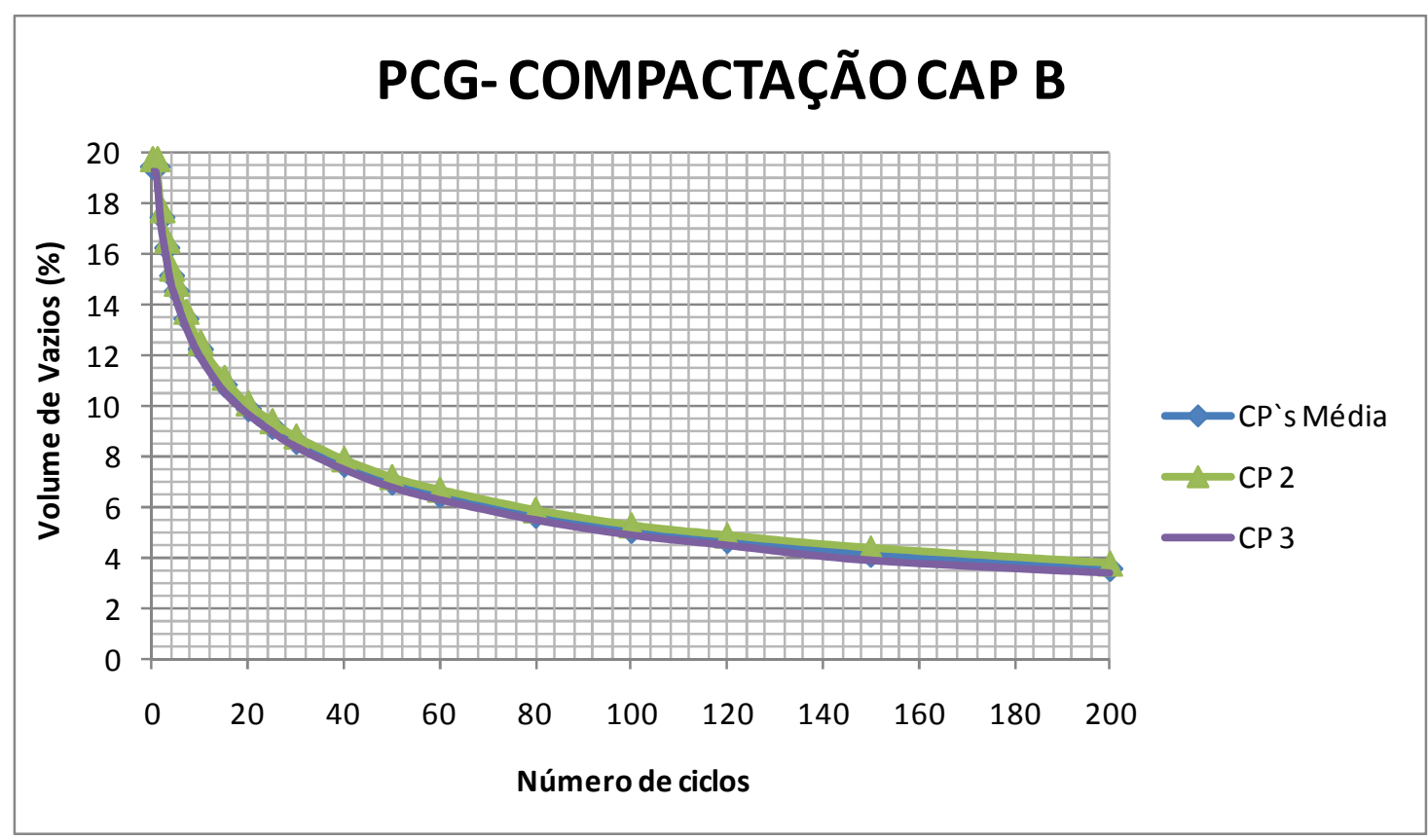

Figura 31 - Gráfico da compactação da mistura de módulo elevado com CAP B - PCG 


\subsection{DANO POR UMIDADE INDUZIDA - AASHTO 283 e NBR 15617}

O ensaio de dano por unidade induzida foi realizado no Laboratório de Tecnologia de Pavimentação - LTP USP e repetido no Centro de Pesquisas Rodoviárias- CPR NovaDutra, para o CAP A. Para o CAP B o ensaio foi realizado somente no Centro de Pesquisas Rodoviárias - CPR. Os ensaios de dano por umidade induzida foram elaborados apenas para as misturas com CAP de módulo elevado.

O ensaio seguiu como referência a norma americana AASHTO T283/2010 Resistance of compacted asphalt mixtures to moisture induced damage e norma brasileira ABNT NBR 15.617/2011 Misturas Asfálticas - Determinação do dano por umidade induzida. $O$ ensaio foi realizado para condicionamento de elevada severidade, sendo que o valor referenciado na norma brasileira é o atingimento mínimo de $75 \%$ obtido pela razão entre as resistências à tração das amostras condicionadas e não condicionadas. A Figura 32 ilustra partes dos procedimentos para o ensaio. 


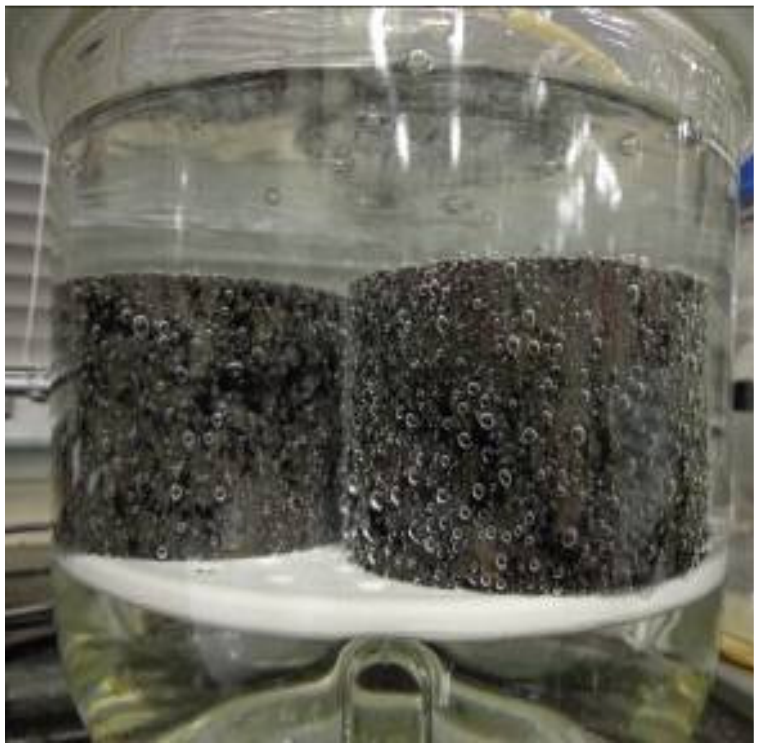

a) $3 \mathrm{CPs}$ com vazios de $7 \% \pm 1 \%$ em recipiente com água destilada e aplicação de vácuo por 5 a $10 \mathrm{~min}$, com intuito de se obter grau de saturação dos vazios de $70 \%$ a $80 \%$ de água

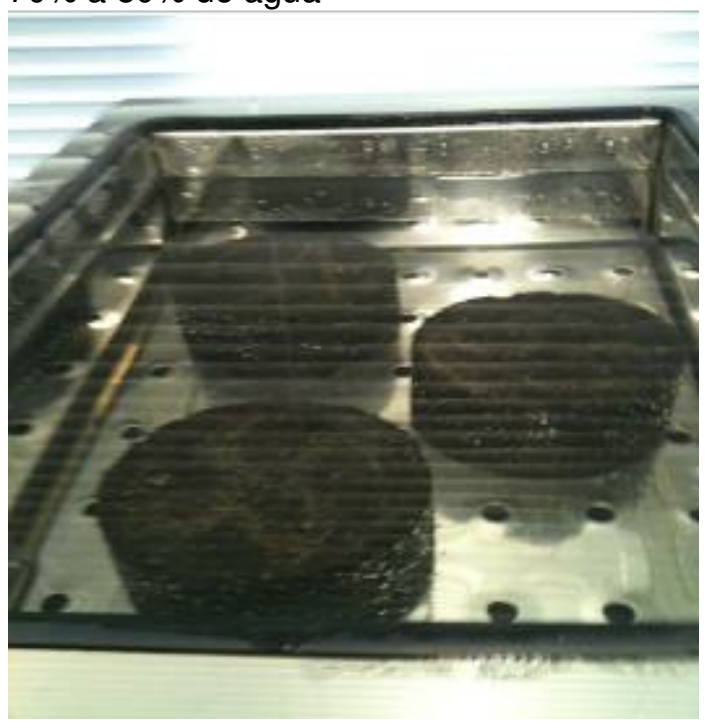

c) Após congelamento os $3 \mathrm{CPs}$ são imersos em banho maria a $25^{\circ} \mathrm{C}$ po $2 \mathrm{~h} \pm 1 \mathrm{~h}$

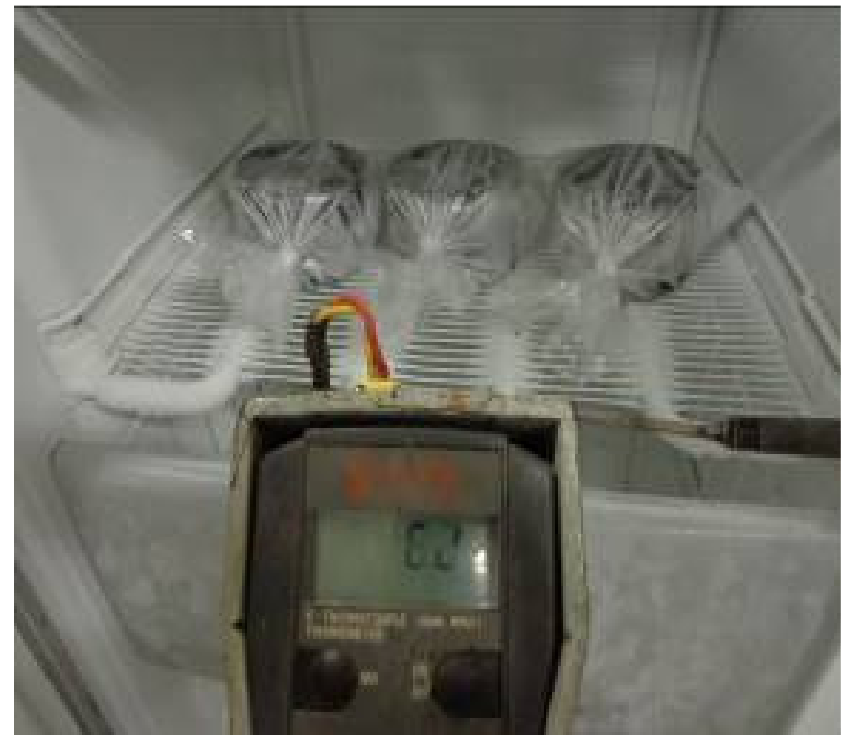

b) 3 CPs envoltos por sacos plásticos com $10 \mathrm{ml}$ de água, vedados e colocados para congelamento ($18^{\circ} \mathrm{C}$ ) por $16 \mathrm{~h}$

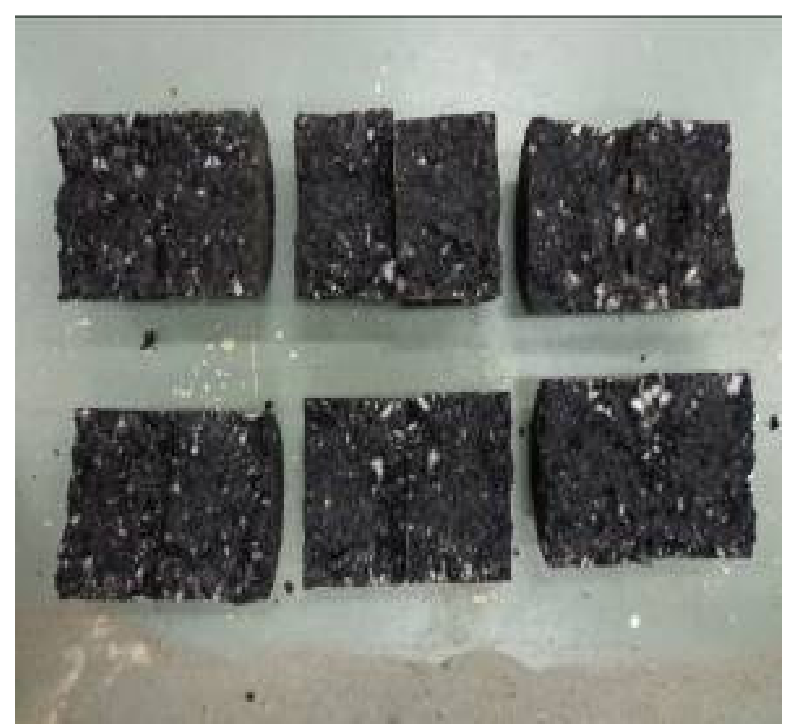

d) 3 CPs condicionados e 3 CPs não condicionados após ensaio de resistência a tração (mistura de módulo elevado)

Figura 32 - Ensaio de dano por umidade induzida , LTP-USP.

A mistura elaborada com o CAP A atende o critério normativo brasileiro, que exige que a relação entre as resistências às trações da amostra natural e amostra condicionada, superior a 75\%. A mistura com o CAP A apresentou o valor da relação da resistência à tração retida $(\mathrm{RRT})$ de 86,6\%. 
O ensaio para a mistura com o CAP B apresentou, no primeiro momento, valor inferior ao estabelecido por norma (50,7\%). O ensaio foi repetido e novamente 0 resultado apresentou um valor inferior ao parâmetro normativo $(51,5 \%)$. Diante da repetição do ensaio e do não atingimento do limite normativo, optou-se por realizar o ensaio de dano por umidade induzida com adição de 1,5\% de cal à mistura. Com a adição de cal notou-se que foi possível melhorar a adesividade e com isso atingiu-se valor de $91,7 \%$ referente à resistência à tração retida das amostras. O ensaio foi repetido novamente, mas neste momento com a adição de dope à mistura, uma vez que os demais ensaios na pesquisa foram reproduzidos sem a adição de cal à mistura. No ensaio de dano por umidade induzida realizado na mistura asfáltica elaborada com o CAP B com a adição de $0,4 \%$ de dope, a mistura apresentou resultado de $99,4 \%$, atendendo neste caso o parâmetro normativo. Os resultados estão representados na Tabela 25.

Tabela 25 - Resultado de dano por umidade induzida das misturas de módulo elevado

\begin{tabular}{c|c}
\hline $\begin{array}{c}\text { DANO POR UMID ADE INDUZIDA (AASHTO 283 } \\
\text { e NBR 15617) }\end{array}$ \\
\hline \multicolumn{1}{c}{ CAP } & $\begin{array}{c}\text { \% Relação entre RT } \\
\text { (condic./não condic.) }\end{array}$ \\
\hline CAP A & $86,6 \%$ \\
\hline CAP B - ensaio 1 & $50,7 \%$ \\
\hline CAP B - ensaio 2 & $51,5 \%$ \\
\hline CAP B c/ 1,5\% CAL & $91,7 \%$ \\
\hline CAP B c/ 0,4\% DOPE & $99,4 \%$ \\
\hline
\end{tabular}

Assim, a mistura asfáltica elaborada com o CAP A está apta para aplicabilidade, no entanto a mistura asfáltica elaborada com o CAP B precisa de um melhorador de adesividade. 
Este capítulo aborda procedimentos e parâmetros adotados para os ensaios mecânicos desta pesquisa, bem como seus resultados. O objetivo é avaliar se as misturas ensaiadas com os ligantes asfálticos, CAP A e CAP B, atentem ou não aos parâmetros desejados para uma mistura de módulo elevado comparativamente com mistura asfáltica usinada com CAP 30/45. Nesta pesquisa, foram empregados os ensaios de deformação permanente, resistência à tração por compressão diametral, módulo de resiliência em equipamentos distintos (MTS e UTM), módulo dinâmico, fadiga por compressão diametral e fadiga por flexão de 4 pontos. Todos os ensaios foram realizados para as misturas usinadas com os três tipos de ligantes asfálticos empregados na pesquisa, com o intuito de estabelecer comparações entre os resultados de ensaio.

\subsection{DEFORMAÇÃO PERMANENTE}

O procedimento de ensaio iniciou com a moldagem e compactação da placa e posteriormente sua simulação no simulador de tráfego francês, onde a placa é mantida a $60^{\circ} \mathrm{C}$. Foram moldados um par de placas para cada mistura, sendo que as dimensões consideradas para as placas foram de $180 \mathrm{~mm} \times 500 \mathrm{~mm} \times 100 \mathrm{~mm}$. Os ensaios seguiram procedimento normativo descrito em NF EN12697/2008Méthodes d'essai pour mélange hydrocarboné à chaud. A mistura passou por compactação no equipamento de compactação pneumática - Systeme de compactage de plaques d'enrobes e posteriormente foi ensaiada no simulador de tráfego francês - Matériels dês laboratories des ponts et chaussées. A Figura 33 demonstra partes do procedimento do ensaio de deformação permanente. 


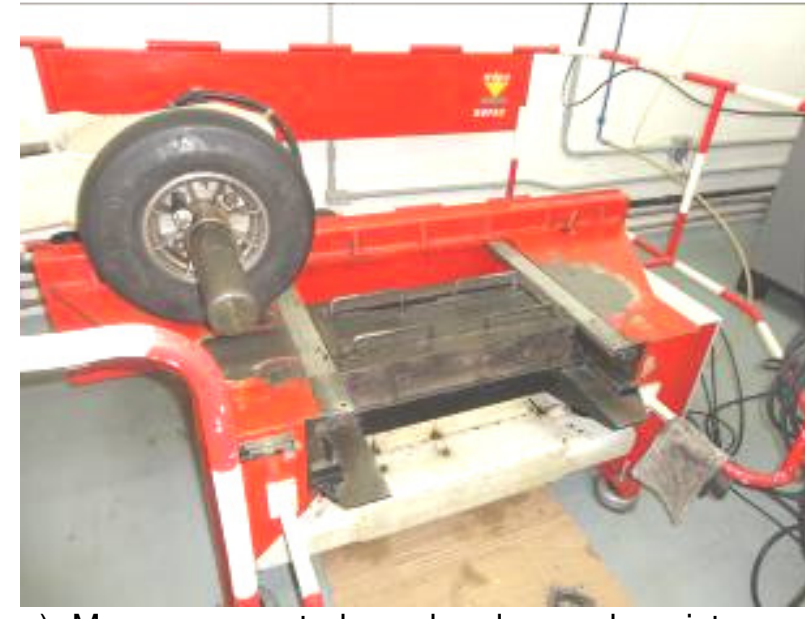

a) Mesa compactadora de placas de misturas asfálticas LCPC

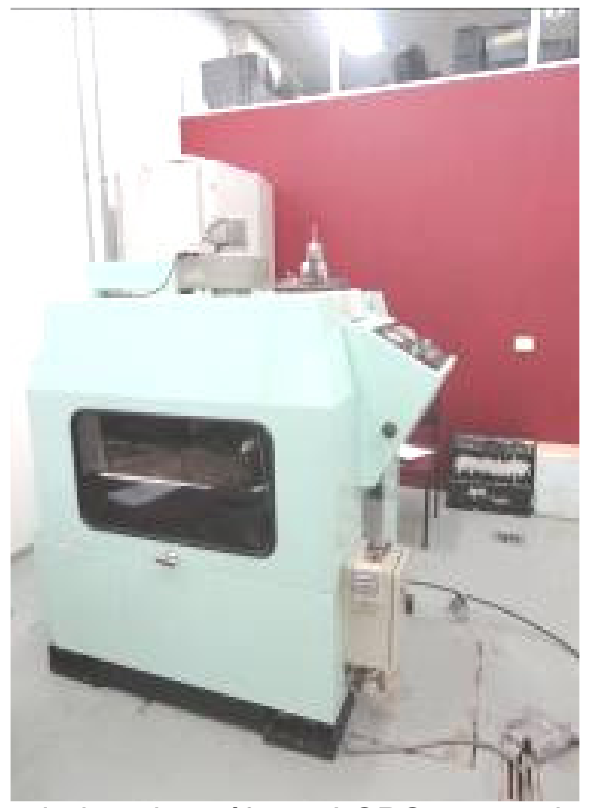

c) Simulador de tráfego LCPC com placa da mistura de módulo elevado

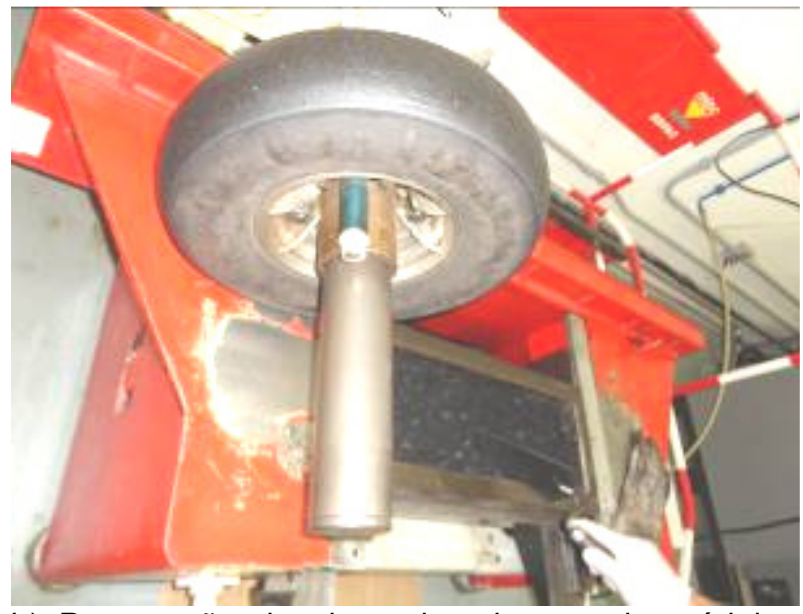

b) Preparação da placa de misturas de módulo elevado - placa com $10 \mathrm{~cm}$ de altura

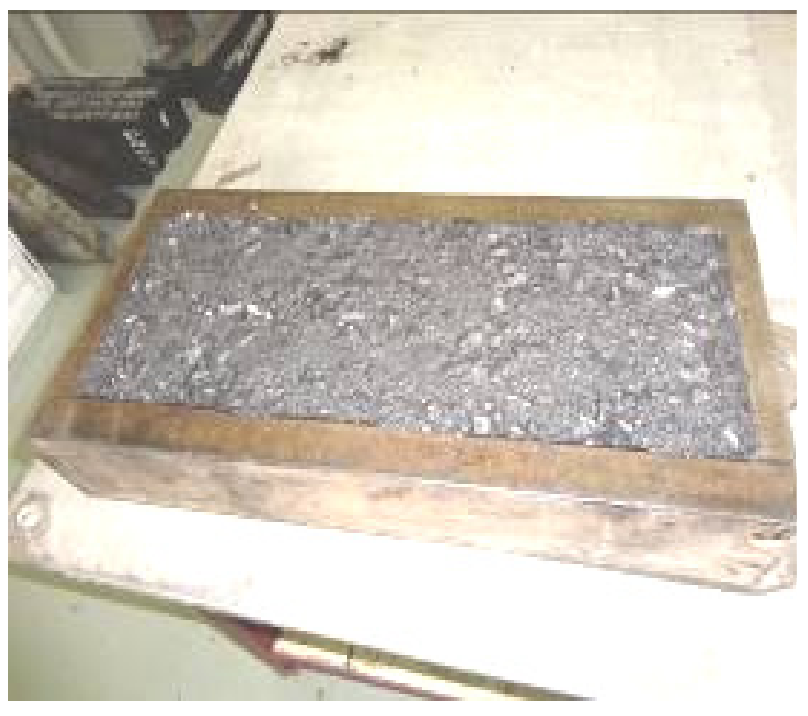

d) Placa de mistura de módulo elevado após ensaio de deformação permanente

Figura 33 - Ensaio de deformação permanente, LTP-USP

Conforme já mencionado para misturas de módulo elevado, estima-se que seu comportamento em relação à deformação permanente seja superior a uma mistura convencional, pois trata-se de uma estrutura mais rígida. Os resultados obtidos atenderam às expectativas, uma vez que as misturas elaboradas com o CAP A e o CAP B apresentaram um bom comportamento à deformação permanente. Os valores de deformação encontrados para estas misturas foram inferiores aos valores de deformação encontrados para a mistura convencional, fato que comprova o melhor desempenho de misturas de módulo elevado em relação à deformação 
permanente. Os valores obtidos neste ensaio estão representados na Tabela 26 e na Figura 34.

Tabela 26 - Resultados de ensaio de deformação permanente para 1.000, 10.000 e 30.000 ciclos

\begin{tabular}{|c|c|c|c|c|c|}
\hline $\begin{array}{c}\text { TEOR DE } \\
\text { LIGANTE (\%) }\end{array}$ & LIGANTE & PLACAS & $\begin{array}{c}\text { DEF. PERMANENTE } \\
(\%) \\
1.000 \text { ciclos } \\
\end{array}$ & $\begin{array}{c}\text { DEF. PERMANENTE } \\
(\%) \\
10.000 \text { ciclos } \\
\end{array}$ & $\begin{array}{c}\text { DEF. PERMANENTE } \\
(\%) \\
30.000 \text { ciclos } \\
\end{array}$ \\
\hline \multirow{3}{*}{4,8} & \multirow{3}{*}{ Cap 30/45 } & Placa 1 & 1,2 & 2,4 & 3,5 \\
\hline & & Placa 2 & 1,4 & 2,7 & 3,5 \\
\hline & & Regressão & 1,4 & 2,6 & 3,5 \\
\hline \multirow{3}{*}{5,5} & \multirow{3}{*}{ CAP A } & Placa 1 & 0,9 & 1,7 & 2,1 \\
\hline & & Placa 2 & 1,0 & 1,8 & 2,1 \\
\hline & & Regressão & 1,0 & 1,7 & 2,1 \\
\hline \multirow{3}{*}{4,8} & \multirow{3}{*}{ CAP B } & Placa 1 & 1,1 & 1,8 & 2,4 \\
\hline & & Placa 2 & 0,9 & 1,5 & 2,2 \\
\hline & & Regressão & 1,0 & 1,7 & 2,2 \\
\hline
\end{tabular}

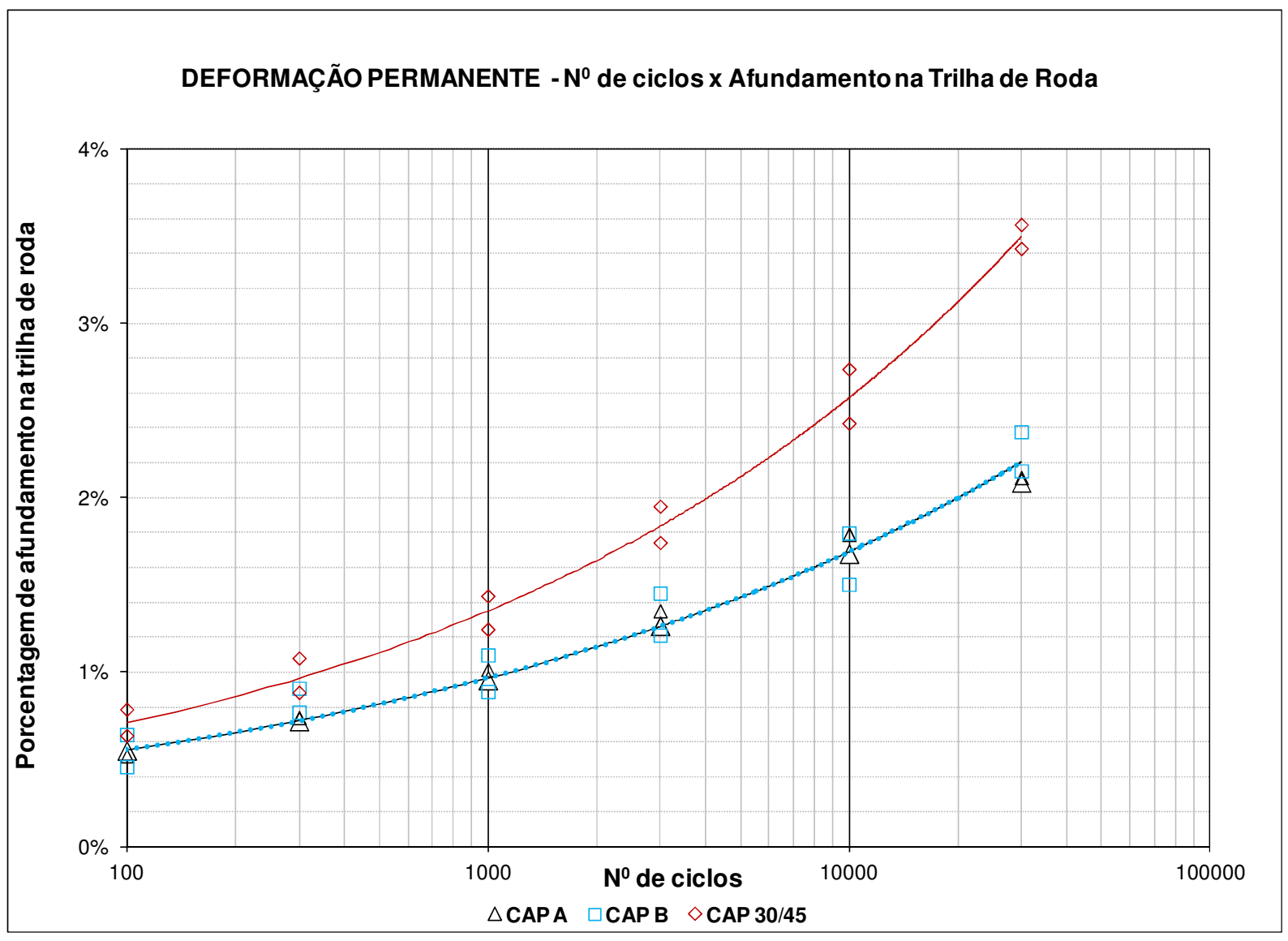

Figura 34 - Deformação permanente das misturas compostas com: CAP A, CAP B e CAP 30/45

A Tabela 27 mostra as equações obtidas das curvas de regressões resultantes dos ensaios de deformação permanente para as misturas deste estudo. Comparou-se também as equações obtidas neste estudo com a equação obtida do ensaio de deformação permanente do estudo de Villela (2012), onde foi empregada a mesma 
curva granulométrica utilizada nesta pesquisa, porém com agregados e ligantes distintos. O ligante asfáltico empregado por Villela (2012) também é considerado de módulo elevado. Pode-se notar que o aumento do expoente da equação resulta em valores maiores de deformação permanente da mistura, sendo que as misturas realizadas com CAP de baixa penetração apresentam valores de expoentes inferiores ao valor do CAP convencional, como era de se esperar. Estima-se que a deformação permanente de misturas de módulo elevado seja menor quando comparada com a deformação permanente de misturas convencionais, assim como os resultados apresentados nesta pesquisa.

Tabela 27 - Equações obtidas das curvas de regressão dos ensaios de deformação permanente

\begin{tabular}{|c|c|c|c|c|c|}
\hline CAP & Referência & $\begin{array}{c}\% \\
\text { Ligante }\end{array}$ & $\begin{array}{c}\text { Equação de Deformação } \\
\text { Permamente }\end{array}$ & $\begin{array}{c}\text { Deformação } \\
\text { Permanente } \\
(\%)\end{array}$ & Expoente \\
\hline CAP 30/45 & \multirow{3}{*}{ Estudo laboratorial desta pesquisa } & $4,8 \%$ & $\%$ Def.Perm $=0,0016\left(n^{0} \text { ciclos }\right)^{0,2989}$ & 3,5 & 0,2989 \\
\hline CAP A & & $5,5 \%$ & $\%$ Def.Perm $=0,0018\left(n^{0} \text { ciclos }\right)^{0,2427}$ & 2,1 & 0,2427 \\
\hline CAP B & & $4,8 \%$ & $\%$ Def.Perm $=0,0018\left(n^{\circ} \text { ciclos }\right)^{0,2427}$ & 2,2 & 0,2427 \\
\hline CAP BR (CAP duro) & $\begin{array}{l}\text { Estudo laboratorial para aplicação } \\
\text { em campo (VILLELA, 2012) }\end{array}$ & $5,8 \%$ & $\%$ Def.Perm $=0,0028\left(n^{\circ} \text { ciclos }\right)^{0,1822}$ & 1,2 & 0,1822 \\
\hline
\end{tabular}

\subsection{RESISTÊNCIA À TRAÇÃO POR COMPRESSÃO DIAMETRAL}

Foram realizados ensaios de resistência à tração na prensa mecânica do CPRNovaDutra por tratar-se de um ensaio rápido e prático. O valor de RT (resistência à tração) obtido foi utilizado como parâmetro para a determinação das tensões para ensaios de fadiga por compressão diametral e na escolha da carga a ser aplicada axialmente para o ensaio de módulo de resiliência. A Figura 35 mostra 0 equipamento e CP resultante do ensaio de resistência à tração.

O ensaio seguiu padronização brasileira NBR 15087/2012 - Misturas Asfálticas Determinação da Resistência à tração por compressão diametral. 


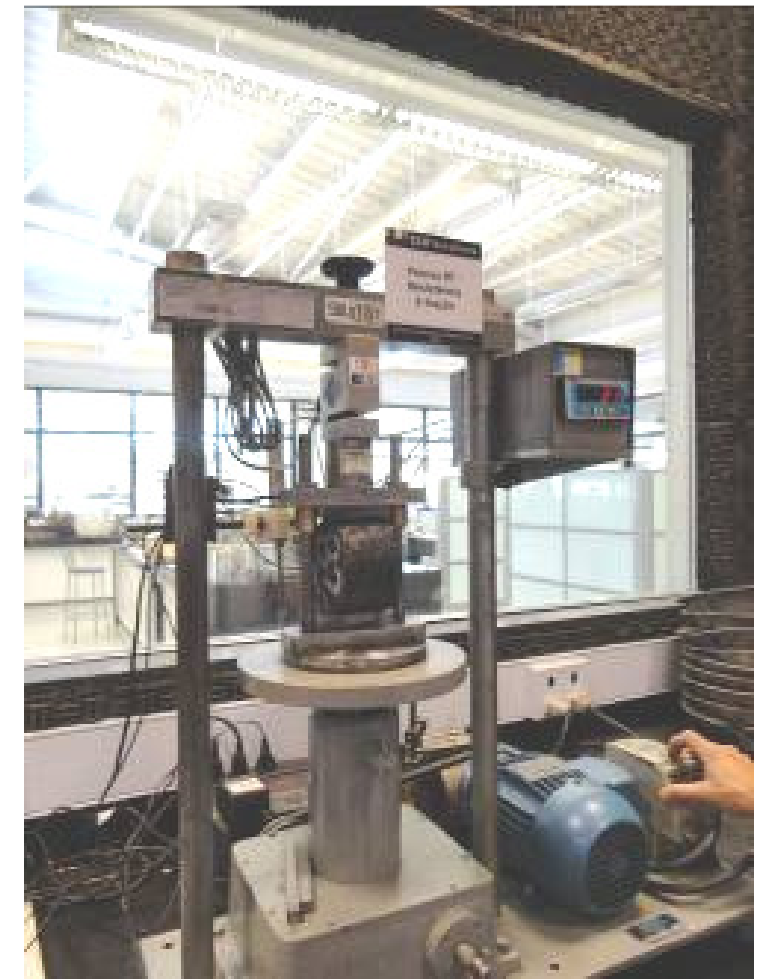

a) Prensa utilizada no ensaio de resistência à tração com dispositivo centralizador e CP de uma das misturas em estudo (módulo elevado)

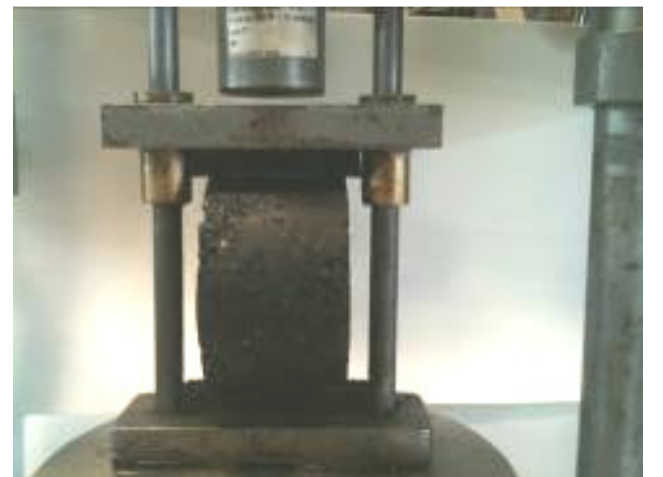

b) Preparação do CP para início do ensaio

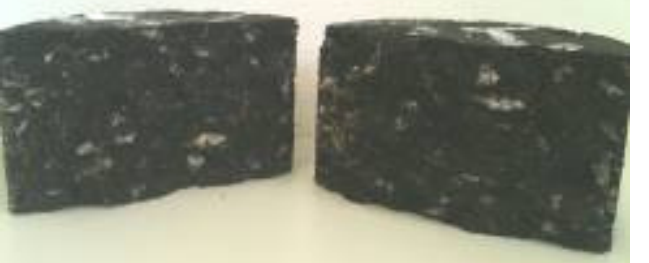

c) Resultado do CP rompido pelo ensaio de resistência à tração- $\mathrm{CP}$ de mistura de módulo elevado

Figura 35 - Equipamento para ensaio de RT (prensa), CPR-NovaDutra

Os resultados dos ensaios podem ser observados na Tabela 28. O CAP B apresentou maior valor de RT, quando comparado com os outros dois CAPs, fato que demonstra o seu melhor comportamento para este ensaio uma vez que é mais resistente aos esforços pelos quais é submetido. O CAP A possui um valor de RT semelhante ao CAP convencional 30/45, fato interessante, uma vez que sua caracterização o enquadra em um ligante asfáltico de módulo elevado, no entanto seu valor de RT a $25^{\circ} \mathrm{C}$ ficou bastante inferior ao RT da mistura usinada com o CAP B.

Tabela 28 - Resultados do ensaio de RT para as misturas estudadas

\begin{tabular}{l|c|c}
\hline \multicolumn{1}{c|}{ CAP } & $\begin{array}{c}\text { Teor de } \\
\text { Ligante }\end{array}$ & $\begin{array}{c}\text { Resistência à } \\
\text { Tração }(\mathbf{M P a})\end{array}$ \\
\hline CAP A & $5,5 \%$ & 2,4 \\
\hline CAP B & $4,8 \%$ & 3,2 \\
\hline CAP 30/45 & $4,8 \%$ & 2,3 \\
\hline
\end{tabular}




\subsection{RIGIDEZ DAS MISTURAS ASFÁLTICAS}

\subsubsection{Módulo de Resiliência}

O ensaio de módulo de resiliência seguiu padronização americana descrita pela norma ASTM D 7369/2009 - Standard test method for determining the resilient modulus of bituminous mixtures by indirect tension test.

Os ensaios de módulo de resiliência foram realizados em dois tipos de equipamentos, na MTS no Laboratório de Tecnologia de Pavimentação- LTP USP e na UTM-25 no Centro de Pesquisa Rodoviária - CPR NovaDutra, mostradas na Figura 36.

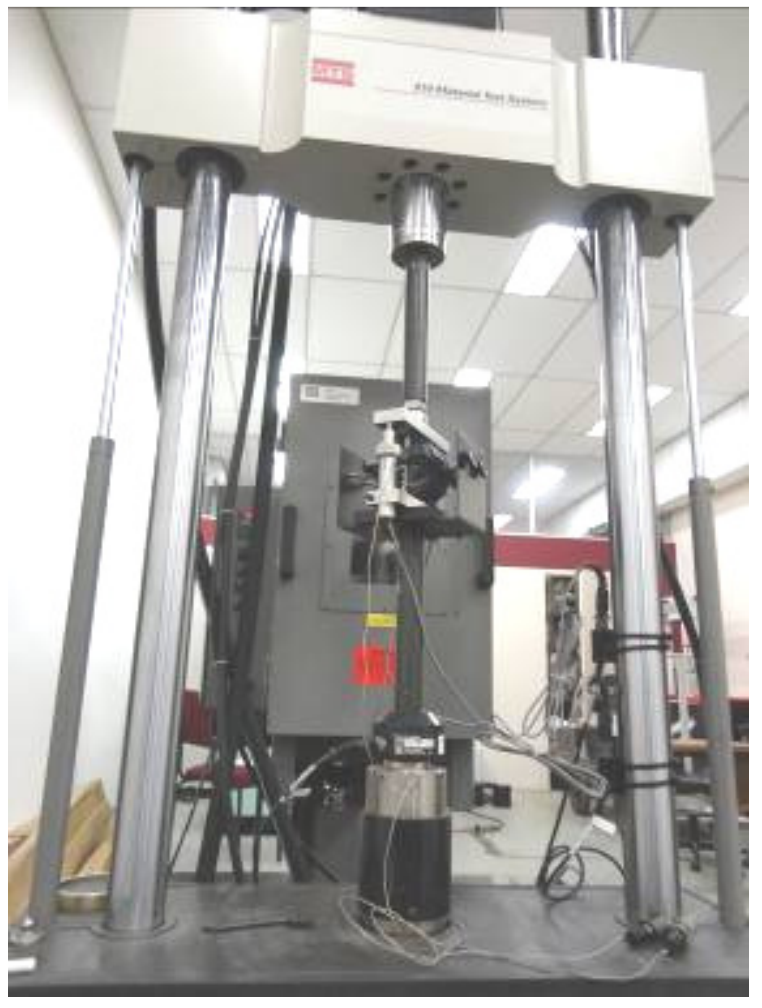

a) Equipamento para ensaio de módulo de resiliência MTS, LTP-USP.

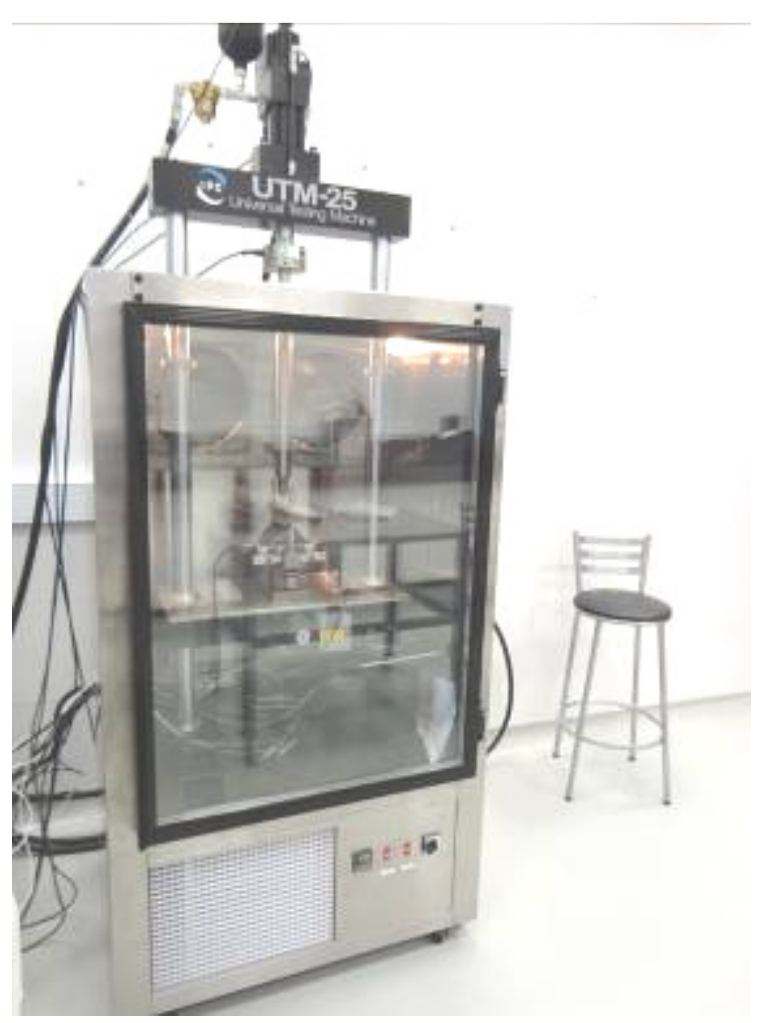

b.) Equipamento para ensaio de módulo de resiliência UTM-25, CPR-NovaDutra.

Figura 36 - Determinação do módulo de resiliência 
Os ensaios de módulo de resiliência foram realizados à temperatura de $25^{\circ} \mathrm{C}$ e frequência de $1 \mathrm{~Hz}$, em laboratórios e equipamentos diferentes com o objetivo de averiguar a variabilidade dos dados.

$\mathrm{Na}$ Figura 37 são apresentados os valores de módulo encontrados. Tinha-se a expectativa que o CAP A, assim como o CAP B, apresentassem módulos de resiliência superiores a $10.000 \mathrm{MPa}$, valores encontrados por Villela (2012) na retroanálise a partir das bacias deflectométricas obtidas em trechos experimentais com base asfáltica de módulo elevado. Os ligantes $A$ e $B$ são fornecidos comercialmente como CAP de módulo elevado ou CAP duro. O CAP A não apresentou os parâmetros numéricos de módulo esperado. Seu módulo de resiliência ficou muito abaixo do que se estimava obter com uma mistura de módulo elevado, tendo atingido valores próximos a $4.900 \mathrm{MPa}$. Já para o CAP B, obtiveramse valores de módulos mais altos, conforme o esperado chegando a atingir 10.600MPa (Tabela 29). Como parâmetro de comparação, utilizou-se uma mistura elaborada com CAP convencional 30/45 cujo módulo encontrado atingiu 5.400MPa. Com este comparativo pode-se observar que uma mistura de módulo elevado possui um valor de módulo de resiliência muito superior ao valor de um módulo de resiliência convencional. Os valores encontrados para módulos de resiliência tanto nos laboratórios quanto nos equipamentos distintos estão bem próximos, fornecendo maior credibilidade à informação. Diante dos resultados, pode-se concluir que a mistura usinada com o CAP B comporta-se efetivamente como uma mistura de módulo elevado diferentemente da mistura usinada com o CAP A. A mistura asfáltica elaborada com o CAP A, um ligante asfáltico de baixa penetração, alta viscosidade e alto ponto de amolecimento e portanto com características de módulo elevado apresentou, no entanto,resultados de módulo de resiliência inferiores ao esperado para este tipo de mistura. 


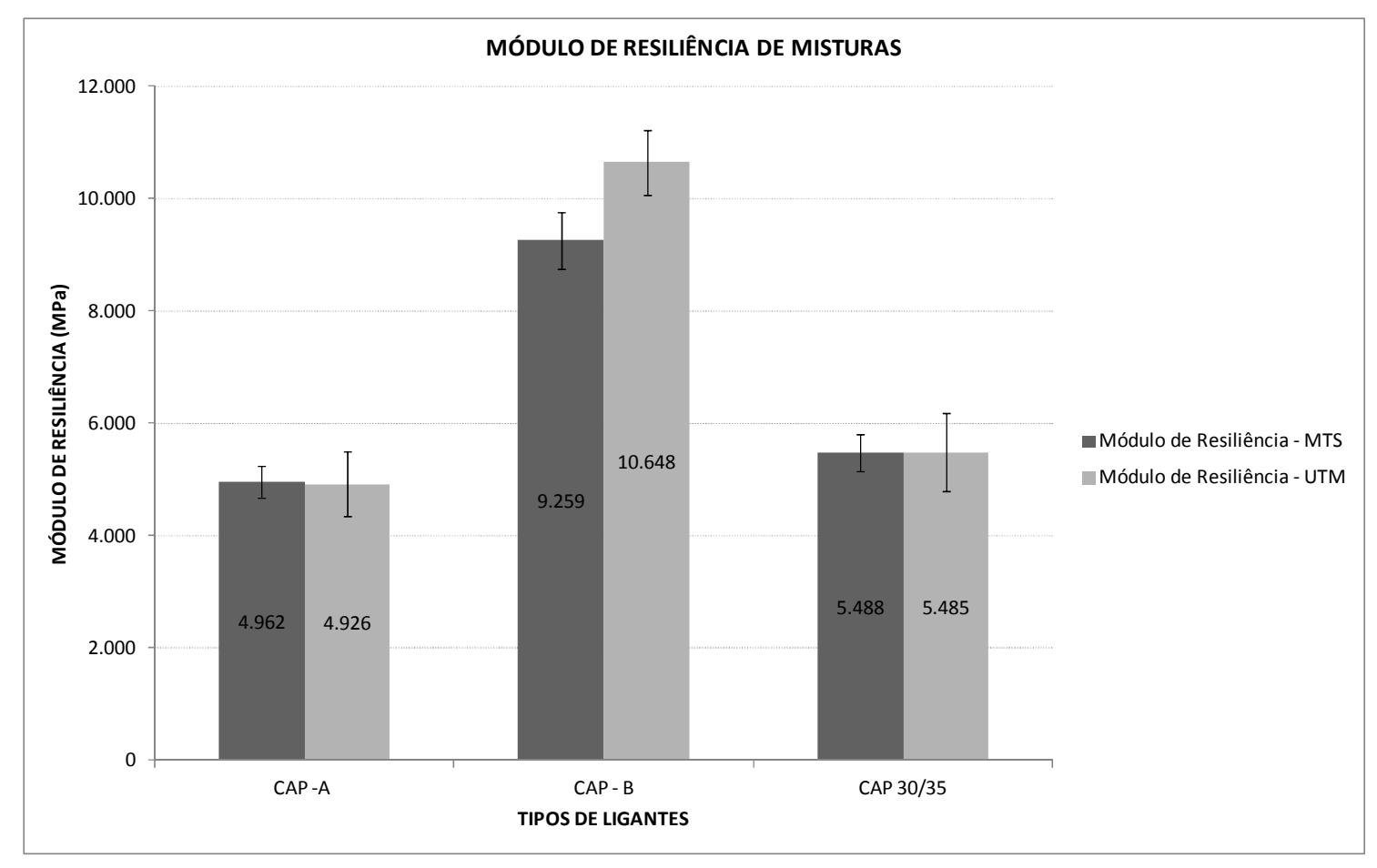

Figura 37 - Representação gráfica do resultado de ensaio de MR nos equipamentos: MTS e UTM

Tabela 29 - Resultados de ensaio de MR

\begin{tabular}{c|c|c|c}
\hline \multicolumn{4}{|c}{ Módulo de Resiliência } \\
\hline & CAP -A & CAP - B & CAP 30/35 \\
\hline MTS & 4.962 & 9.259 & 5.488 \\
\hline DP & 292 & 509 & 329 \\
\hline UTM & 4.926 & 10.648 & 5.485 \\
\hline DP & 567 & 584 & 694 \\
\hline
\end{tabular}

\section{DP - Desvio Padrão}

Realizou-se com os dados de módulo de resiliência uma análise sobre o tempo de resposta destas misturas. Esta análise está representada na Figura 38, onde os gráficos de força $\mathrm{x}$ tempo e deslocamento $\mathrm{x}$ tempo foram plotados. Pode-se notar que o comportamento destes materiais com relação ao tempo de resposta pouco variou de uma mistura para outra. 


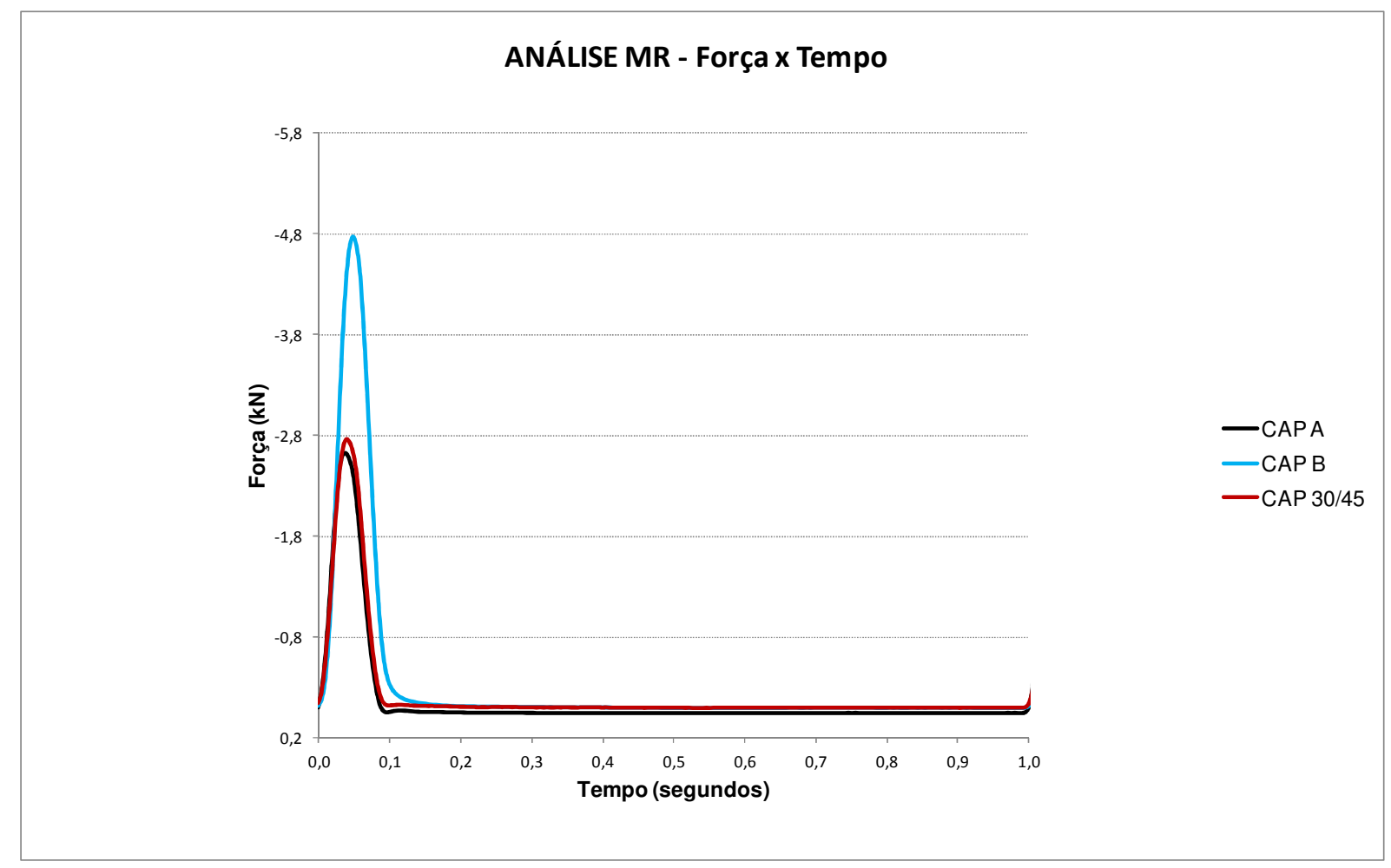

a) Análise referente ao módulo de resiliência das misturas em gráfico de força $x$ tempo

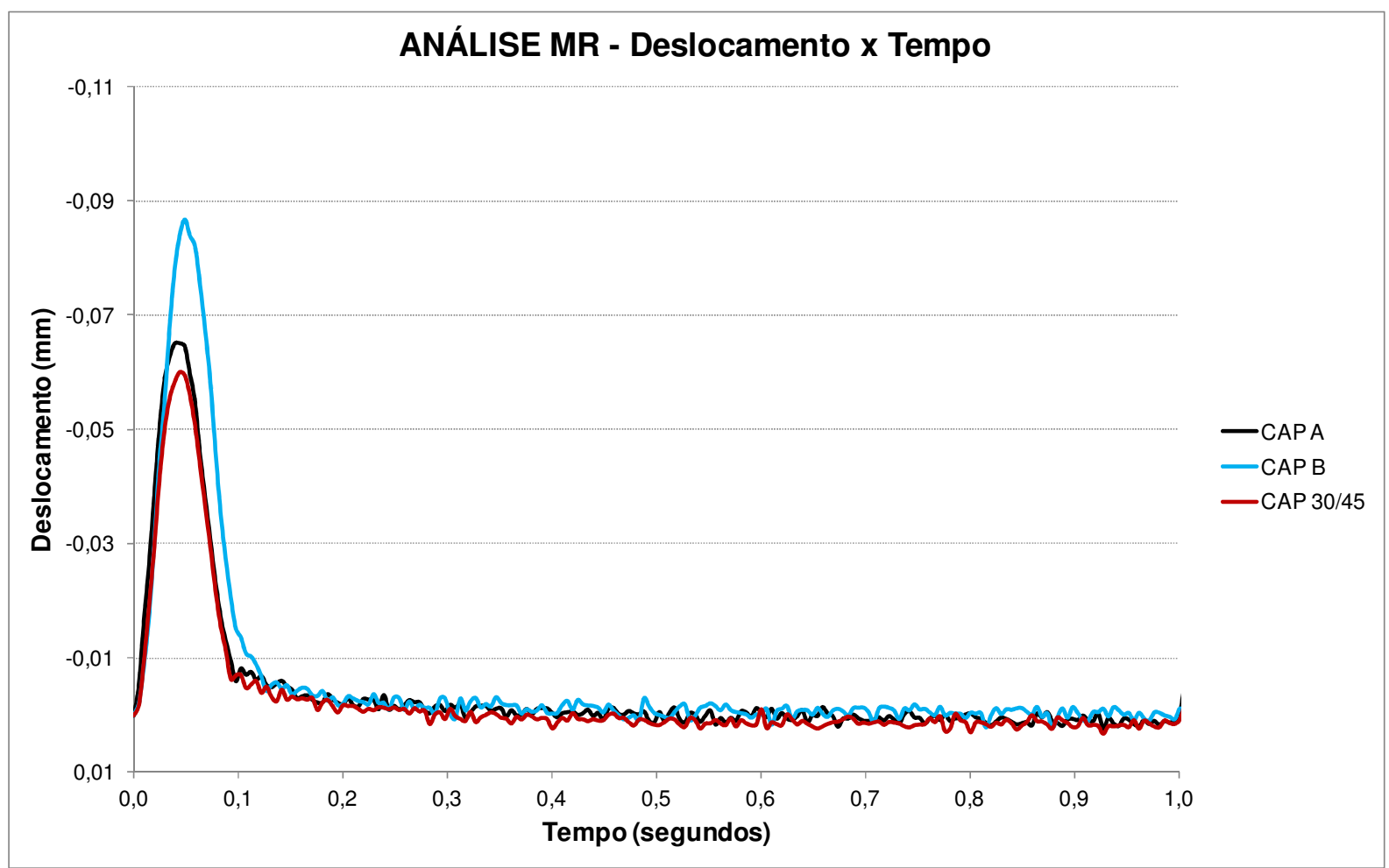

b) Análise referente a módulo de resiliência das misturas em gráfico de deslocamento $\mathrm{x}$ tempo

Figura 38 - Análise de um pulso do ensaio de MR para misturas elaboradas com CAP A, CAP B e CAP $30 / 45$ 


\subsubsection{Módulo Dinâmico}

O módulo dinâmico foi realizado para as três misturas em estudo: mistura de módulo elevado com CAP A, mistura de módulo elevado com CAP B e mistura convencional com CAP 30/45.

Os ensaios de módulo dinâmico foram realizados no Centro de Pesquisas Rodoviárias - CPR NovaDutra, no equipamento UTM-25, seguindo padronização americana ASTM D3497/2003 - Standard Test method for Dynamic Modulus of Asphalt Mixtures. A Figura 39 ilustra o equipamento e a instrumentação do corpo-deprova para o ensaio de módulo dinâmico.

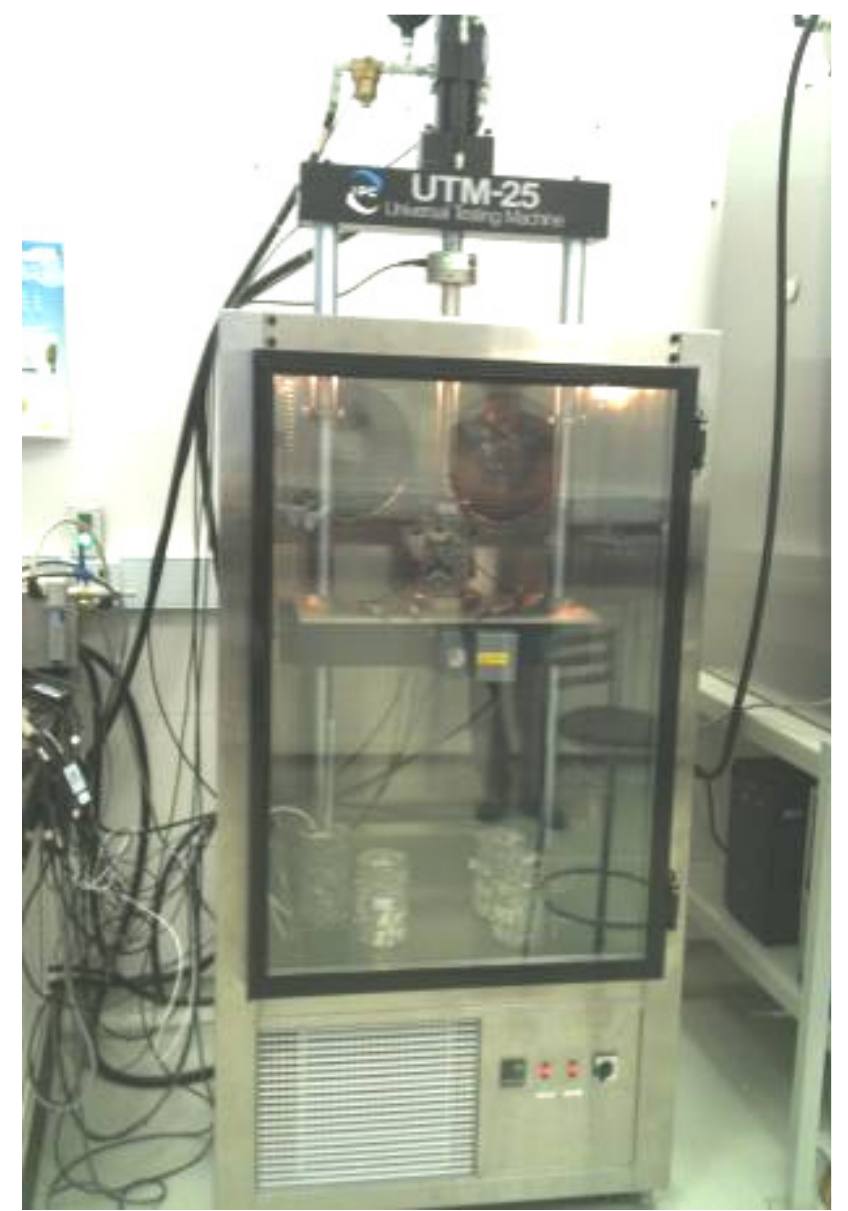

a) Equipamento UTM-25 instrumentado para ensaio de módulo dinâmico, com CP de módulo elevado instrumentado

Figura 39 - Equipamento e instrumentação do ensaio de módulo dinâmico

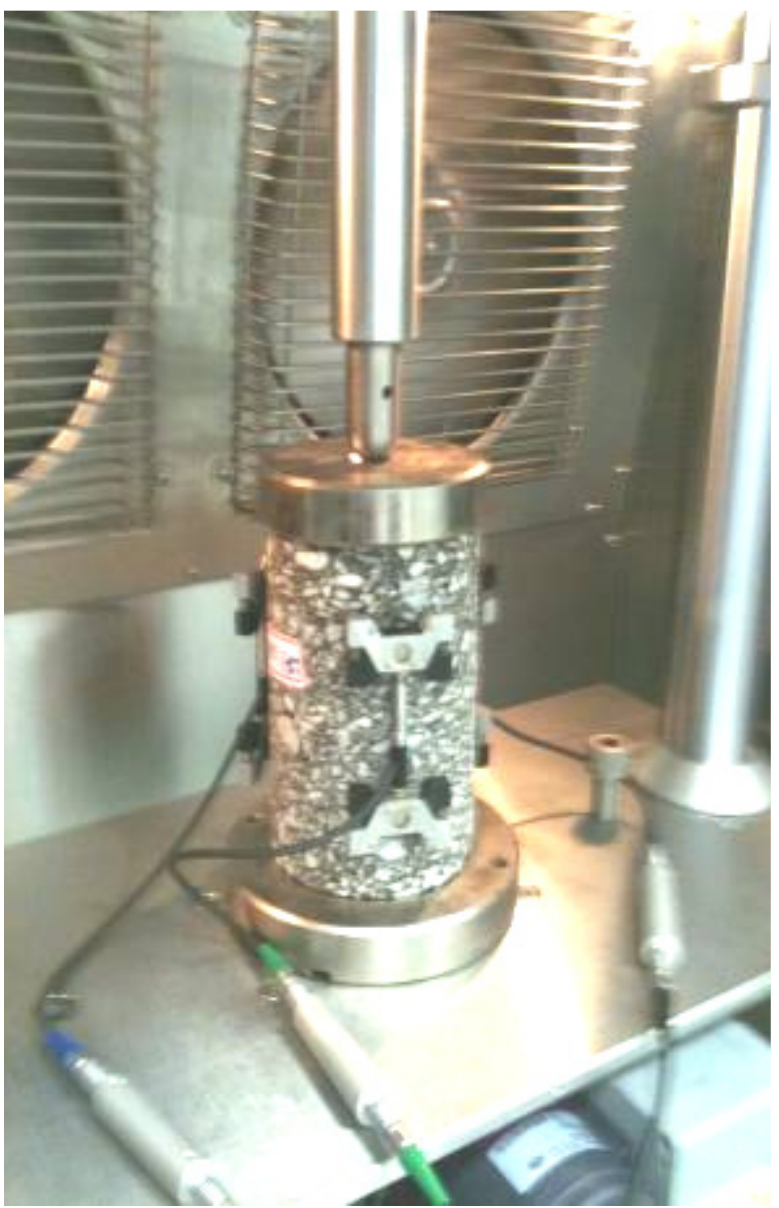

b) Vista aproximada da instrumentação do CP de módulo elevado em estudo para ensaio de módulo dinâmico 
Foram utilizados três corpos-de-prova para cada tipo de mistura asfáltica, sendo que com cada CP realizou-se toda a varredura de frequências $(0,1 \mathrm{~Hz} ; 0,5 \mathrm{~Hz} ; 1 \mathrm{~Hz} ; 5 \mathrm{~Hz}$; $10 \mathrm{~Hz}$ e $25 \mathrm{~Hz})$ e temperaturas $\left(-10^{\circ} \mathrm{C} ; 4,4^{\circ} \mathrm{C} ; 21,1^{\circ} \mathrm{C} ; 37,8^{\circ} \mathrm{C}\right.$ e $\left.54,4^{\circ} \mathrm{C}\right)$. Cada $\mathrm{CP}$ possui as dimensões de $100 \mathrm{~mm}$ de diâmetro e $150 \mathrm{~mm}$ de altura, tendo sido todos extraídos de uma mesma placa de $400 \mathrm{~mm} \times 600 \mathrm{~mm} \times 150 \mathrm{~mm}$, conforme Figura 40, moldada na mesa compactadora LCPC com 2 pneus. O resultado do ensaio foi obtido pela média aritmética dos CPs ensaiados. A mistura elaborada com o CAP A apresentou a média de três CPs com volume de vazios médio de $6,7 \%$. O resultado da mistura elaborada com o CAP B foi obtido pela média de dois CPs, uma vez que o volume de vazios do terceiro CP extrapolou os valores médios utilizados, sendo que o valor médio do volume de vazios dos CPs desta mistura foi de 7,3\%. O mesmo fato ocorreu para a mistura elaborada com o CAP 30/45. Dos três CPs ensaiados, um deles apresentou volume de vazios inferior aos valores médios das demais misturas, assim foram considerados os valores médios de dois CPs, sendo que o volume de vazios médio para a mistura com o CAP $30 / 45$ foi de $6,9 \%$.

Optou-se por representar os resultados do ensaio de módulo dinâmico de cada mistura asfáltica em função da frequência, sendo que cada curva refere-se a uma dada temperatura de ensaio. Os resultados de módulo dinâmico em função da frequência de ensaio estão apresentados para cada mistura asfáltica de estudo, assim como a curva mestra de cada mistura asfáltica obtida com base nos resultados de ensaios de modulo dinâmico em função da frequência e da temperatura. Os resultados podem ser vistos nas Figuras 41, 42 e 43, que remetem respectivamente às misturas usinadas com CAP A, CAP B e CAP 30/45. A Figura 44 reúne todas as três curvas mestras obtidas na pesquisa. No Apêncice $B$, pode ser observado o comportamento das três misturas juntas em um único gráfico para cada uma das cinco temperaturas estudadas. 


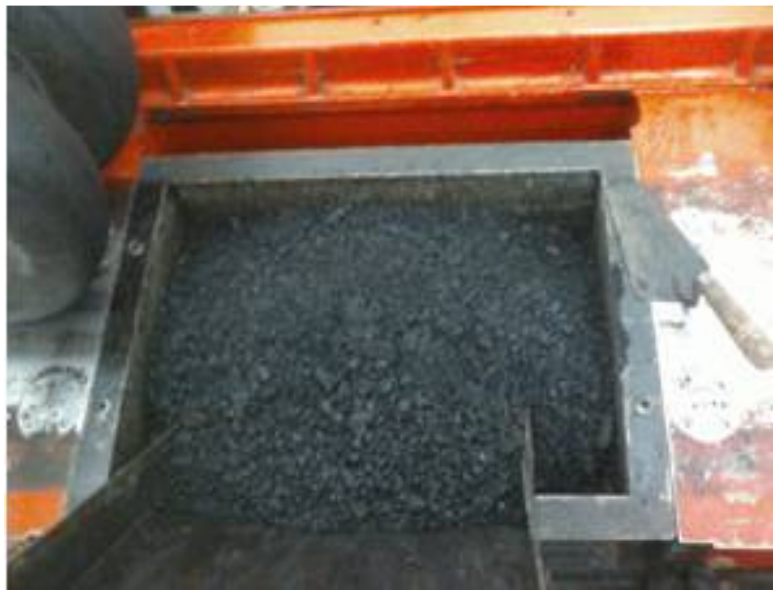

a) Colocação da massa usinada no molde para compactação na mesa compactadora LCPC

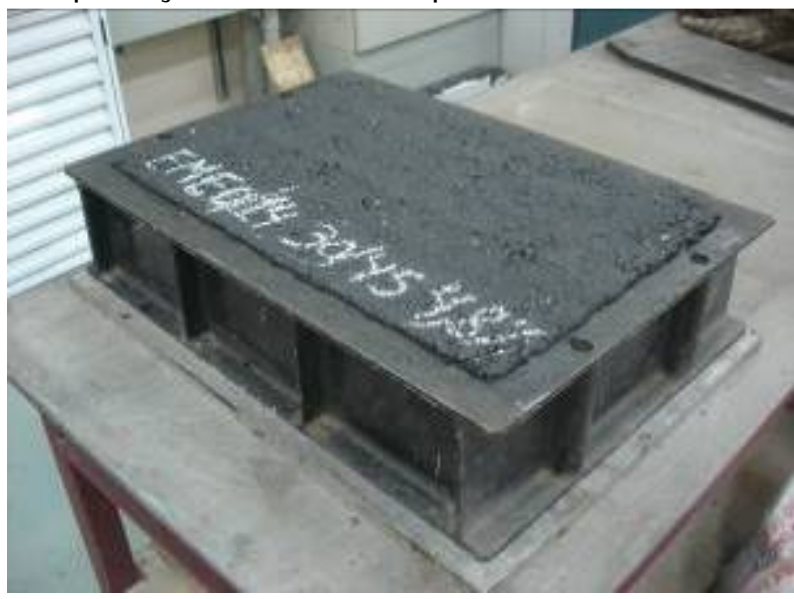

c) Placa após compactação

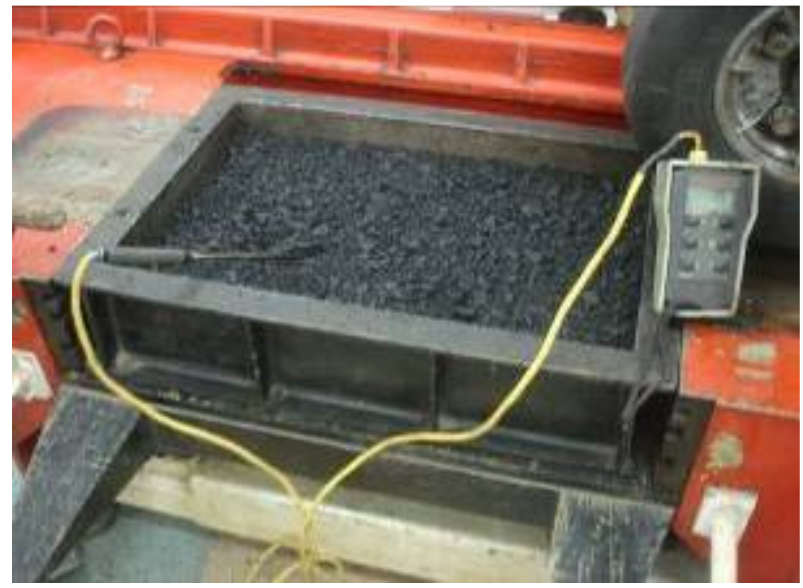

b) Controle de temperatura para realização do processo de compactação

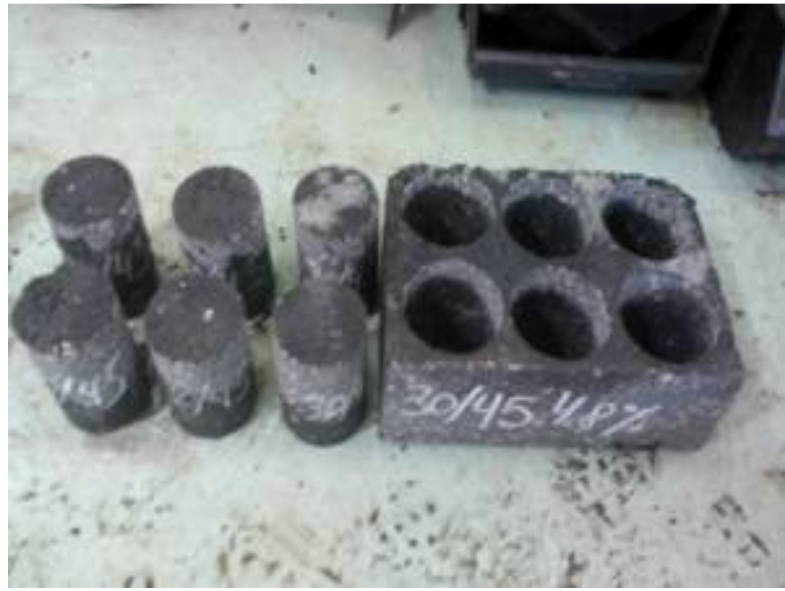

d) Placa broqueada para elaboração dos CPs para ensaio de módulo dinâmico

Figura 40 - Confecção das placas para extração de corpos-de-prova para ensaio de módulo dinâmico 


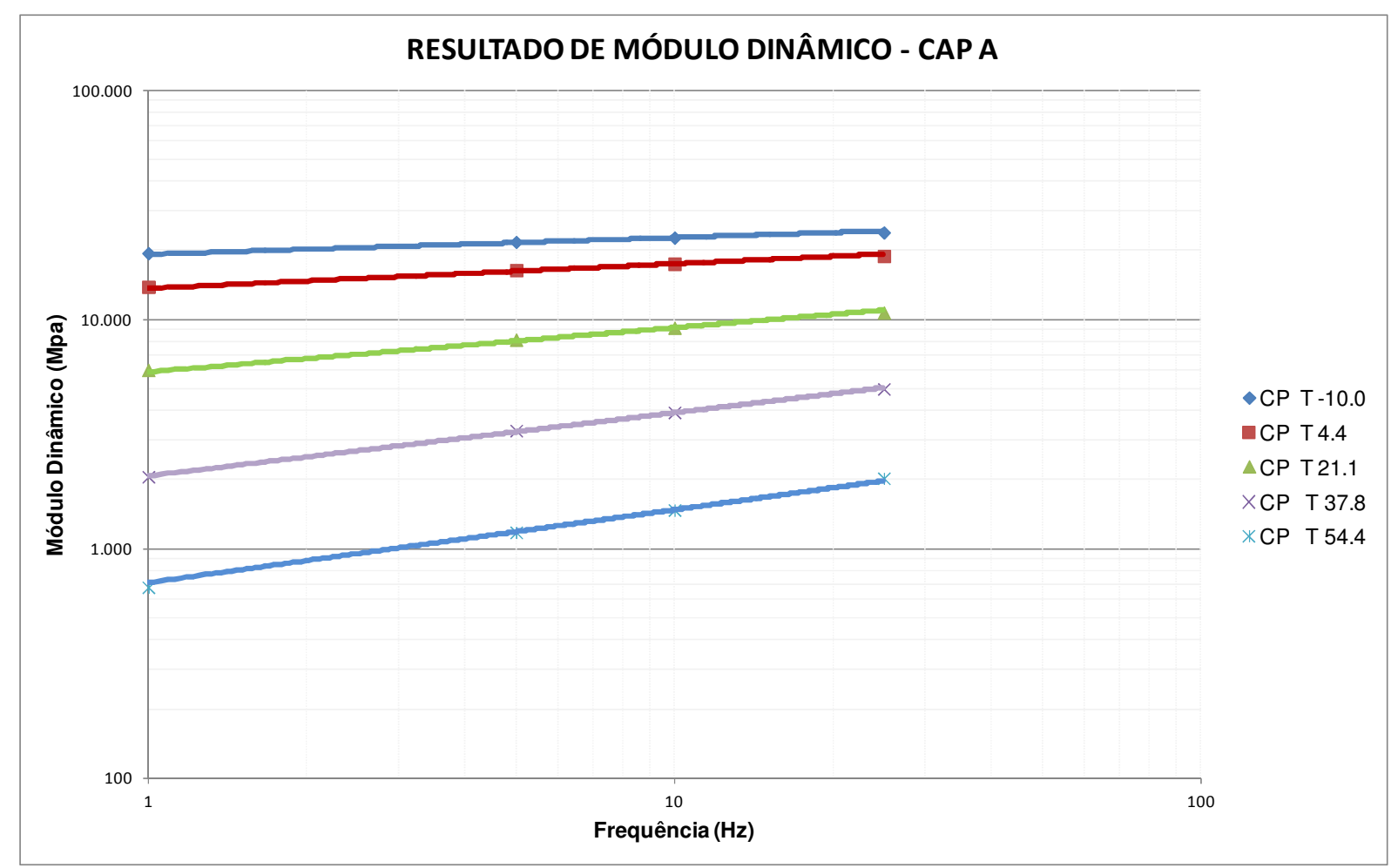

a) Dados do Ensaio em escala logarítmica

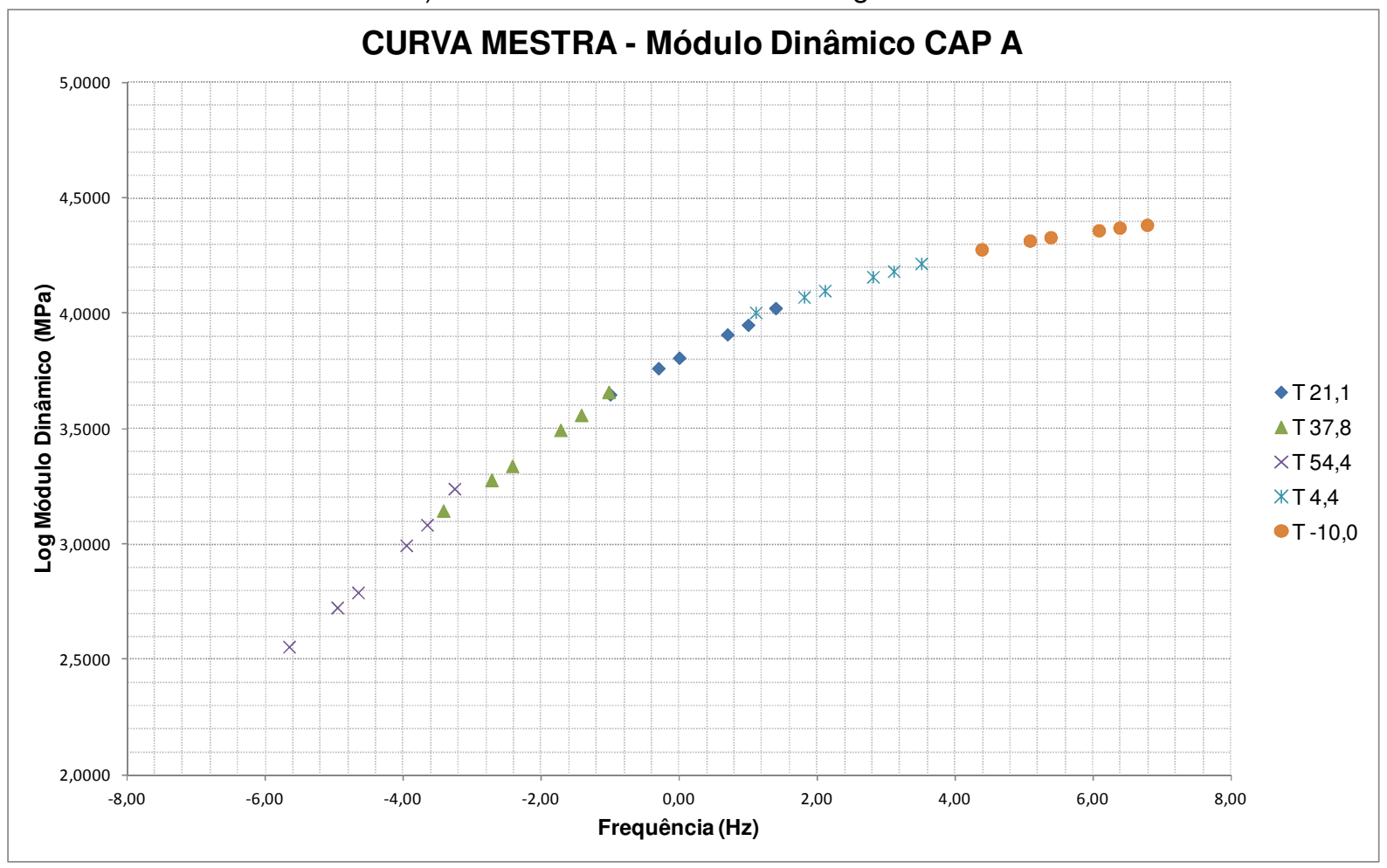

b) Curva Mestra CAP A

Figura 41 - Dados de ensaio de módulo dinâmico e curva mestra para a mistura asfáltica com o CAP A 


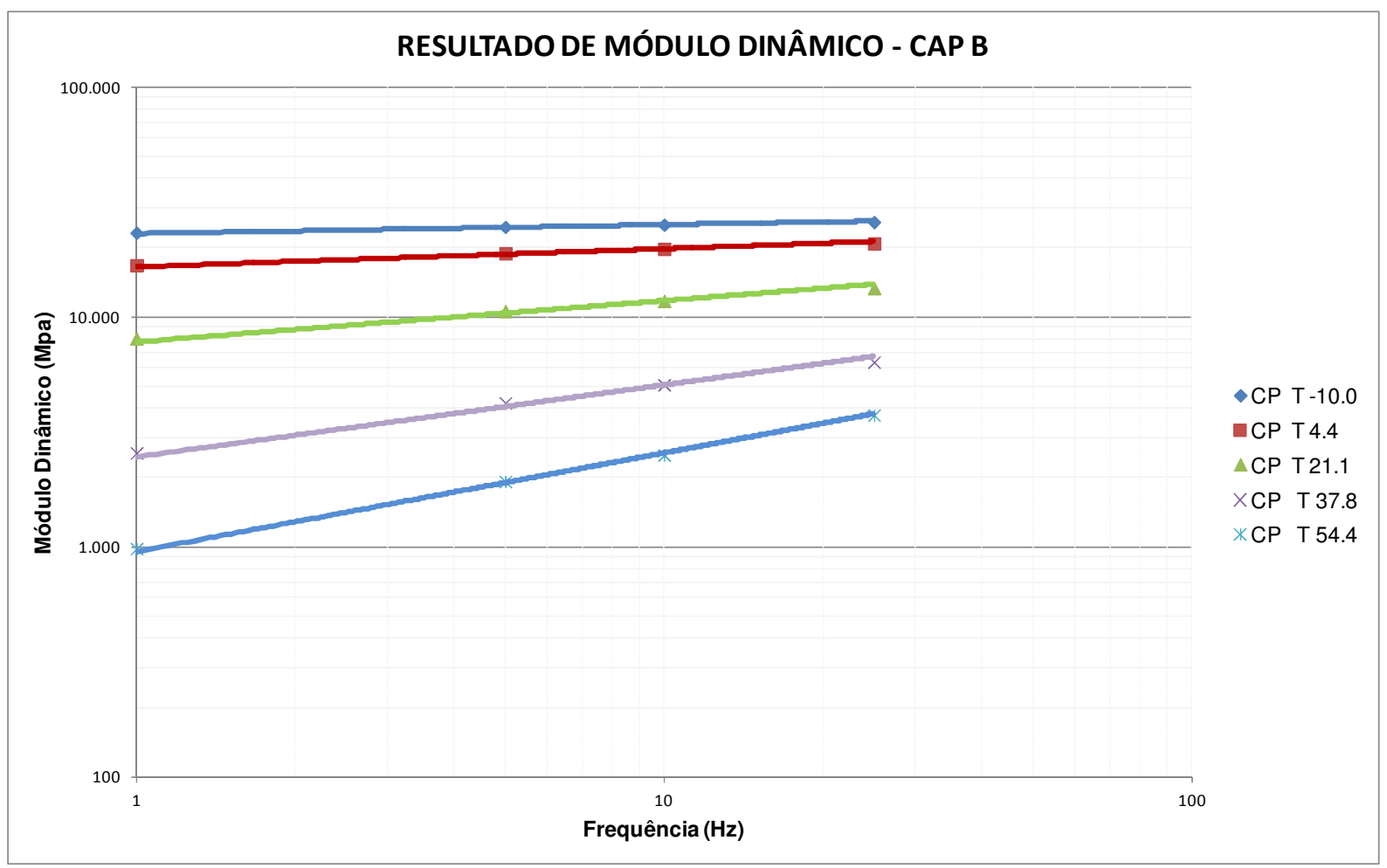

a) Dados do Ensaio em escala logarítmica

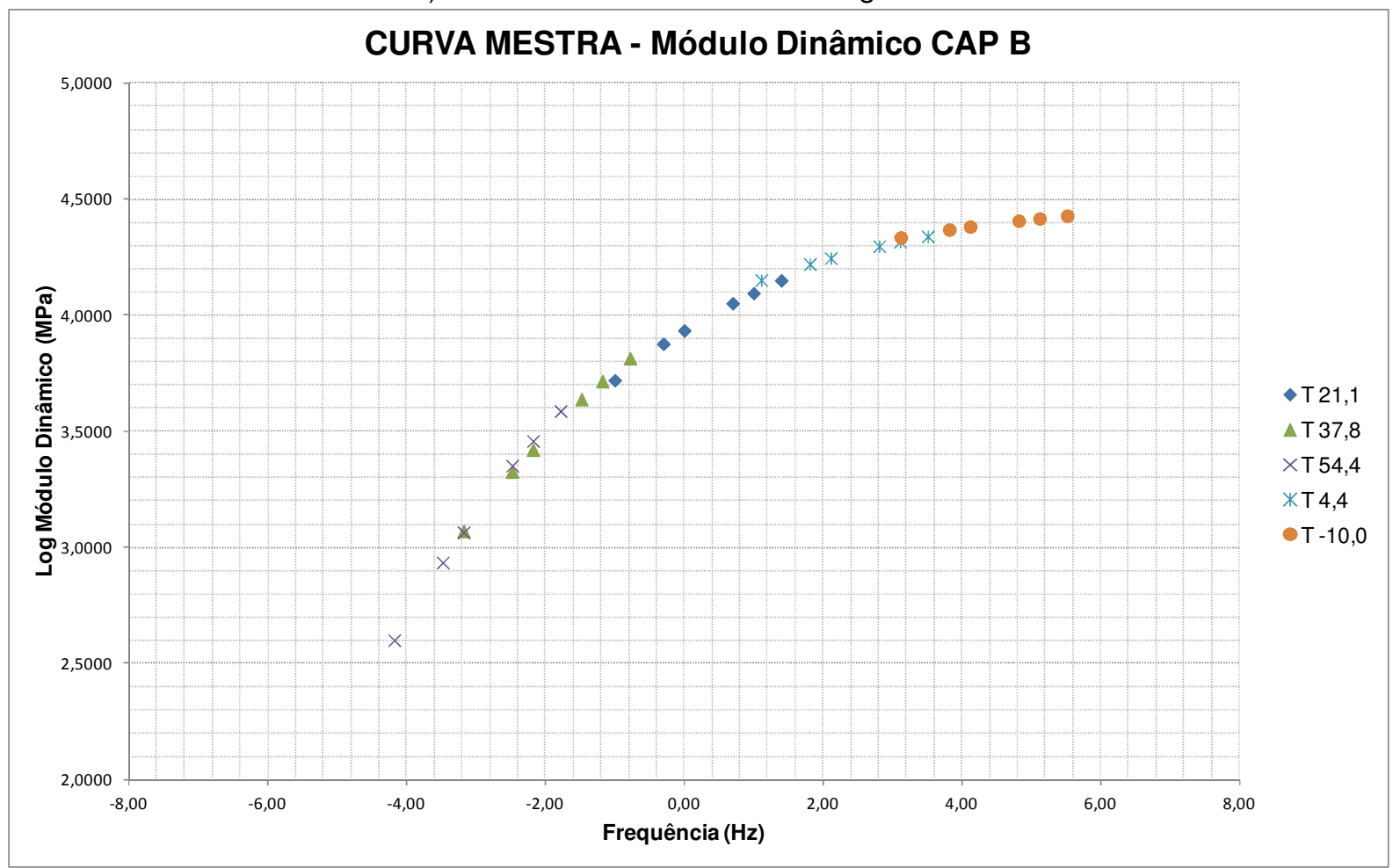

b) Curva Mestra CAP B

Figura 42 - Dados de ensaio de módulo dinâmico e curva mestra para a mistura asfáltica com o CAP B 


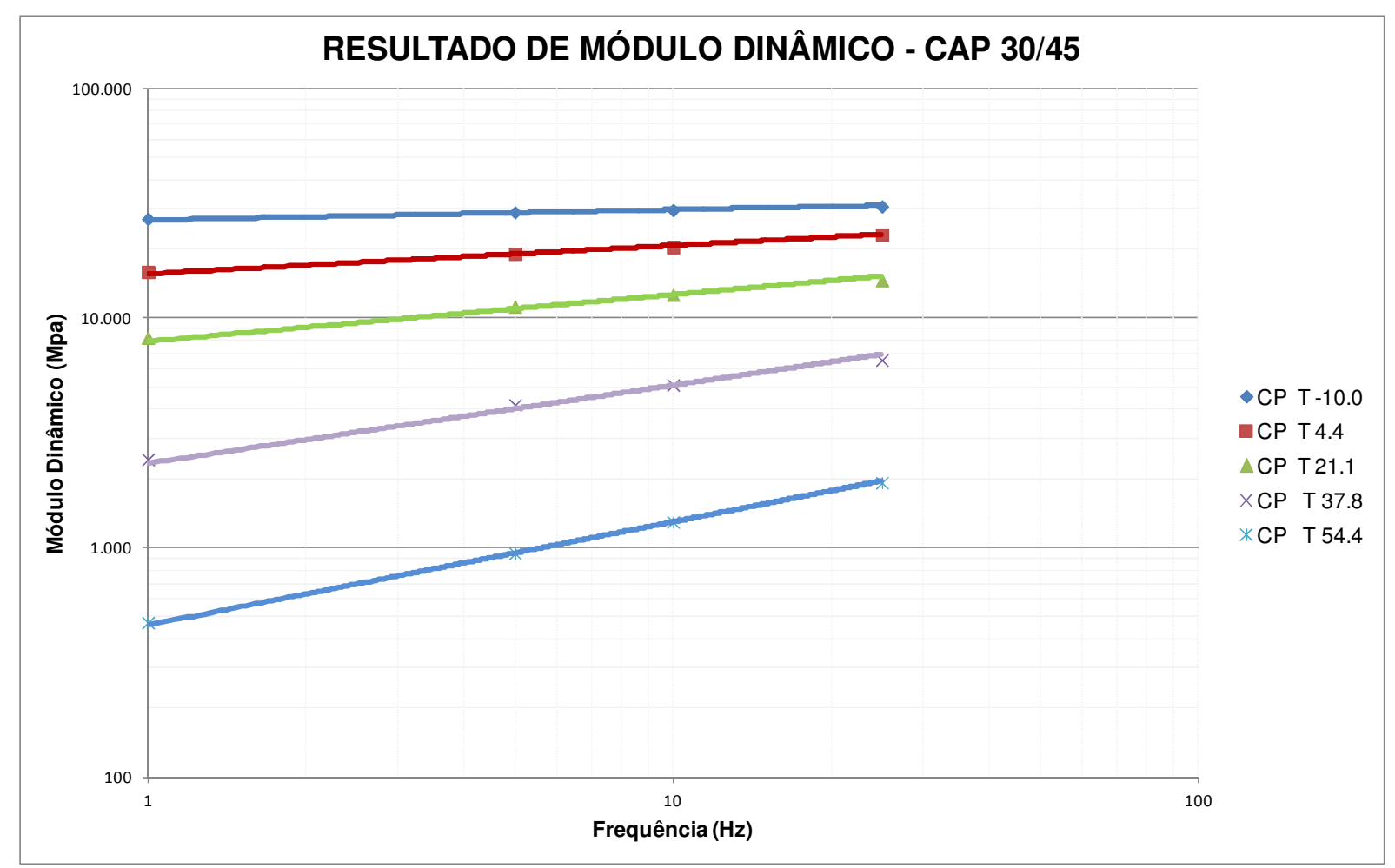

a) Dados do Ensaio em escala logarítmica

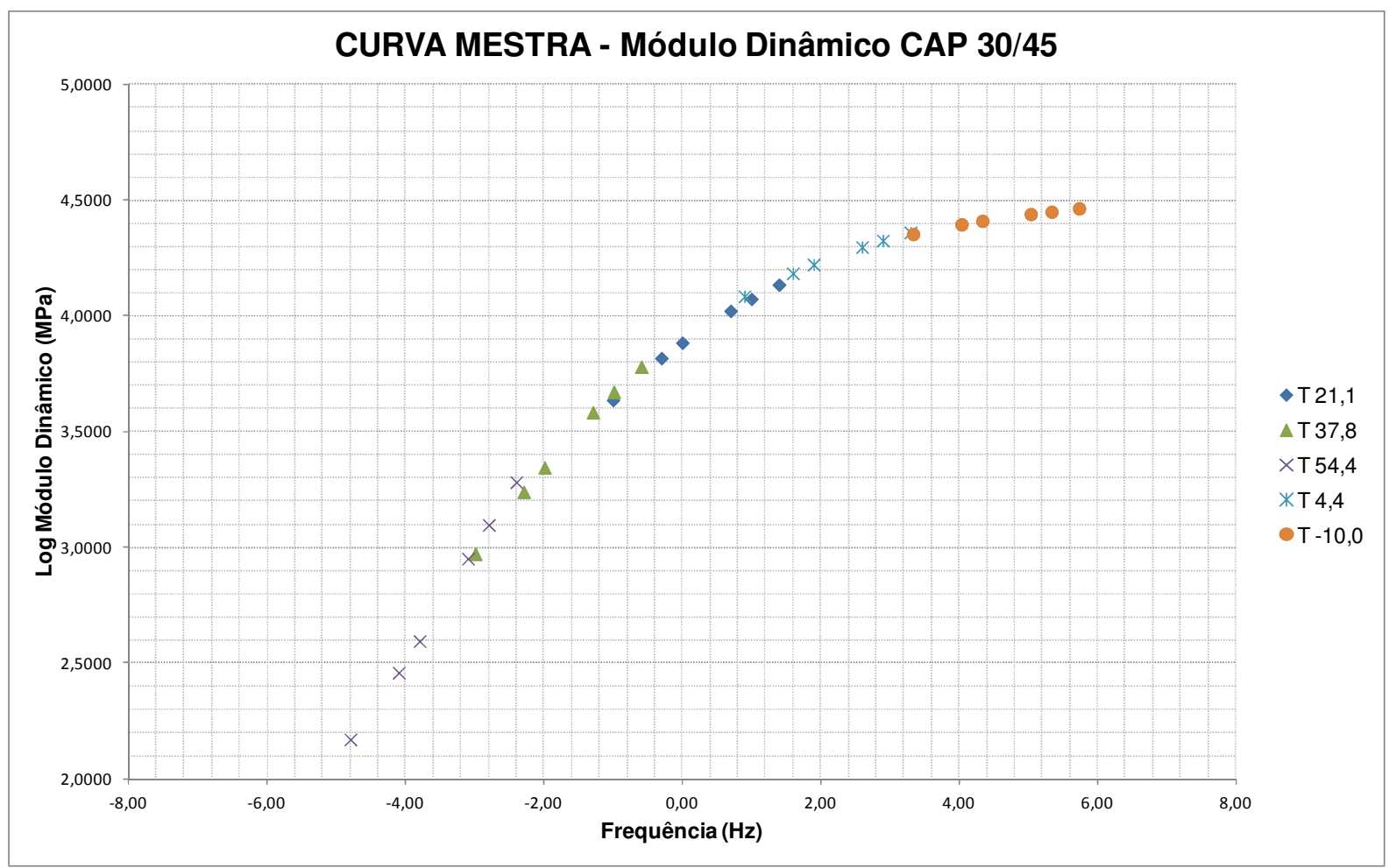

b) Curva Mestra CAP 30/45

Figura 43 - Dados de ensaio de módulo dinâmico e curva mestra para a mistura asfáltica com o CAP $30 / 45$ 
Analisando as três curvas mestras plotadas no mesmo gráfico, Figura 45, pode-se notar comportamentos semelhantes entre os CAPs B e 30/45. Este fato está relacionado à semelhança na viscosidade destes materiais, fato que contribuiu para que a inclinação de suas curvas mestras fossem parecidas.

Com relação à mistura elaborada com o CAP A, pode-se concluir que esta é menos sensível ao efeito da variação de frequência e de temperatura, esta característica é muitas vezes observada em ligantes asfálticos modificados. A presença de modificador no CAP A pode ser também verificado no ensaio MSCR, no qual este ligante asfáltico apresenta recuperação elástica, diferentemente do CAP B.

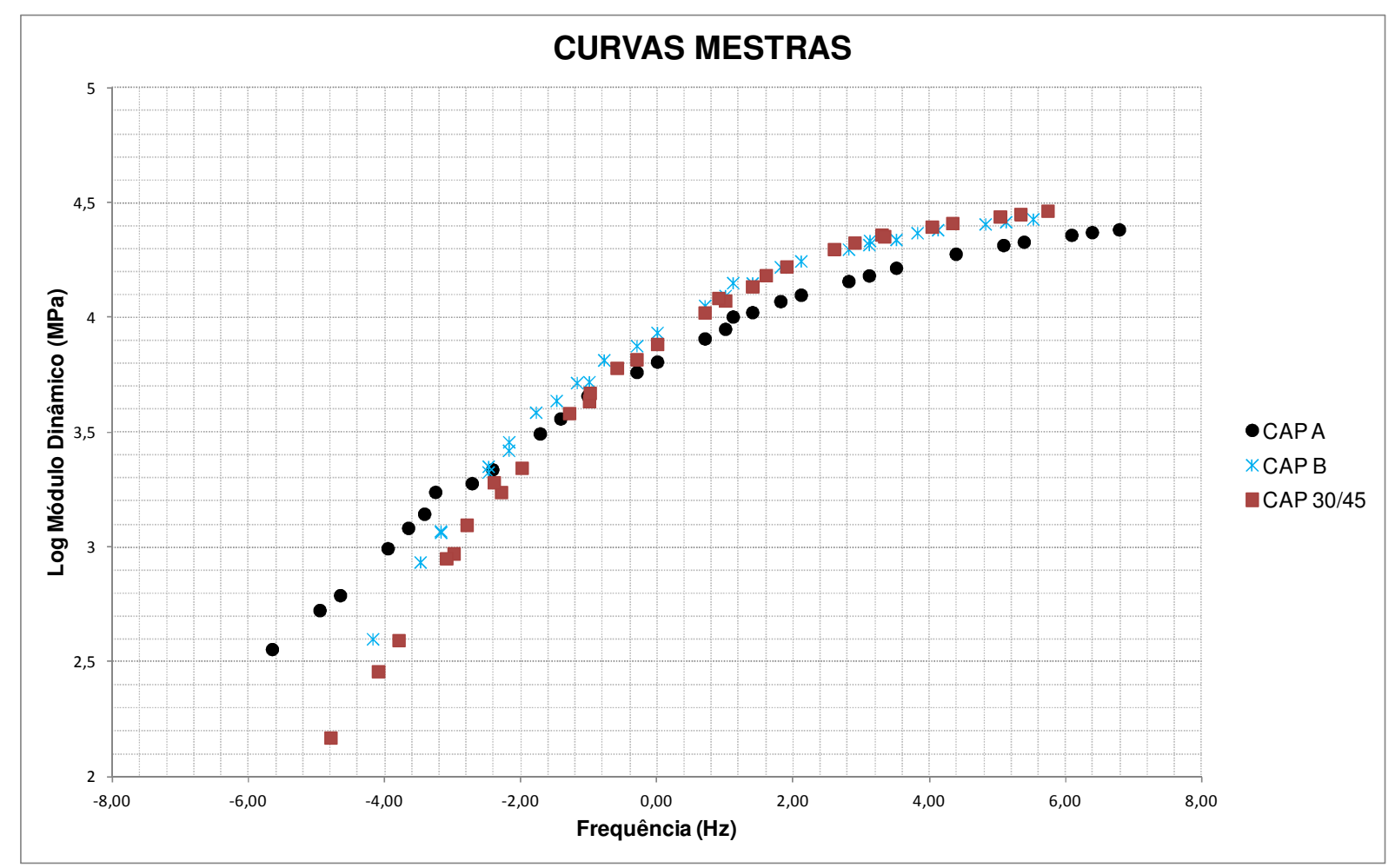

Figura 44 - Curvas mestras das três misturas asfálticas da pesquisa (T de referência $21,1^{\circ} \mathrm{C}$ )

\subsection{FADIGA}

Nesta pesquisa realizou-se dois ensaios de fadiga, fadiga por compressão diametral e fadiga por flexão de 4 pontos. Tratam-se de ensaios de fadiga com características distintas, que se pode observar na Tabela 30. 
Tabela 30 - Características dos ensaios de fadiga empregados neste trabalho

\begin{tabular}{l|l|l}
\hline \multicolumn{1}{c|}{ PARÂMETRO } & \multicolumn{1}{|c|}{ FADIGA POR COMPRESSÃO DIAMETRAL } & FADIGA POR FLEXÃO DE VIGA DE 4 PONTOS \\
\hline Tipo de ensaio & Tensão controlada & Deformação controlada \\
\hline Parâmetros de controle de ensaio & $20 \%, 30 \%, 40 \%$ e $50 \% \mathrm{RT}$ & 300,500 e 800 microstrain \\
\hline Corpos de prova & Cilíndricos: diâmetro de $100 \mathrm{~mm}$ e altura de $635 \mathrm{~mm}$ & $\begin{array}{l}\text { Prismático: vigota } 63 \mathrm{~mm} \text { de largura x } 380 \mathrm{~mm} \text { de } \\
\text { comprimento } \times 50 \mathrm{~mm} \text { de altura }\end{array}$ \\
\hline Temperatura & $25^{\circ} \mathrm{C}$ & $20^{\circ} \mathrm{C}$ \\
\hline Frequência & $1 \mathrm{~Hz}$ & $10 \mathrm{~Hz}$ \\
\hline Forma de carregamento & $0,1 \mathrm{~s}$ de carregamento e $0,9 \mathrm{~s}$ de descarregamento (repouso) & Dinâmico \\
\hline Critério de parada & $1 \mathrm{~mm}$ de deslocamento axial & $50 \%$ de redução da rigidez inicial \\
\hline
\end{tabular}

\subsubsection{Fadiga por tração em ensaio de compressão diametral}

A fadiga por tração diametral foi realizada no equipamento MTS com uma frequência de pulso aplicada de $1 \mathrm{~Hz}$ sendo 0,1s para aplicação da carga senoidal e 0,9 s de repouso. O critério de parada adotado foi de deformação axial de $1 \mathrm{~mm}$. O ensaio de fadiga foi realizado à temperatura controlada de $25^{\circ} \mathrm{C}$ com os corpos-de-prova alocados em uma câmara de controle de temperatura. O ensaio foi realizado à tensão controlada.

Foram selecionados 4 níveis de tensão para este ensaios, sendo que estes níveis foram definidos após resultado de RT (resistência à tração por compressão diametral). Foram estabelecidos os seguintes níveis de tensão:

- alta tensão: $50 \%$ e $40 \%$ do RT da mistura; e

- baixa tensão: $30 \%$ e $20 \%$ do RT da mistura.

A Figura 45 mostra o equipamento utilizado no ensaio e os CPs resultantes do ensaio de fadiga por compressão diametral. 


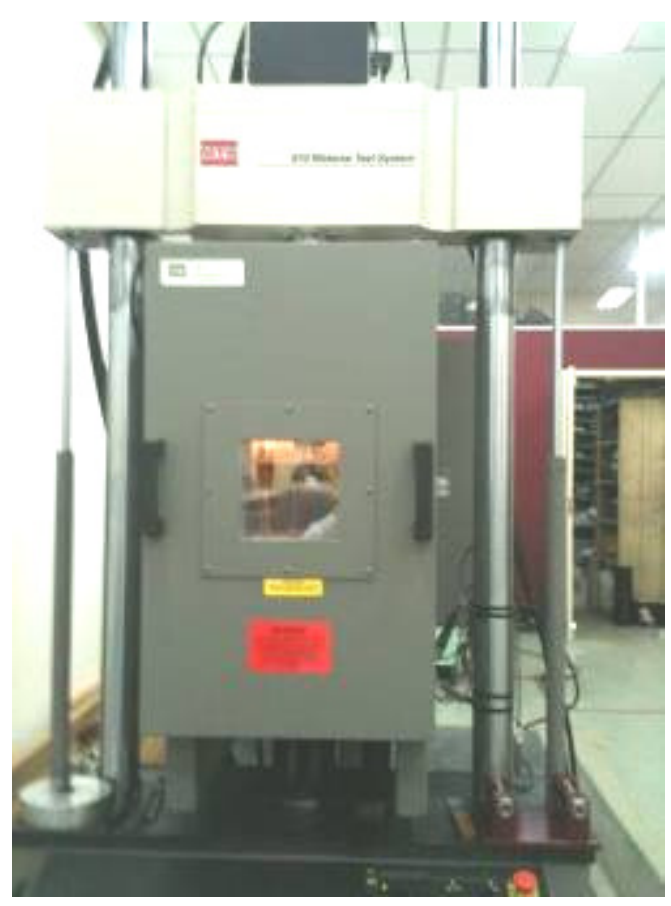

a) Câmara de controle de temperatura para ensaio de fadiga de compressão diametral a temperatura de $25^{\circ} \mathrm{C}$ no equipamento MTS

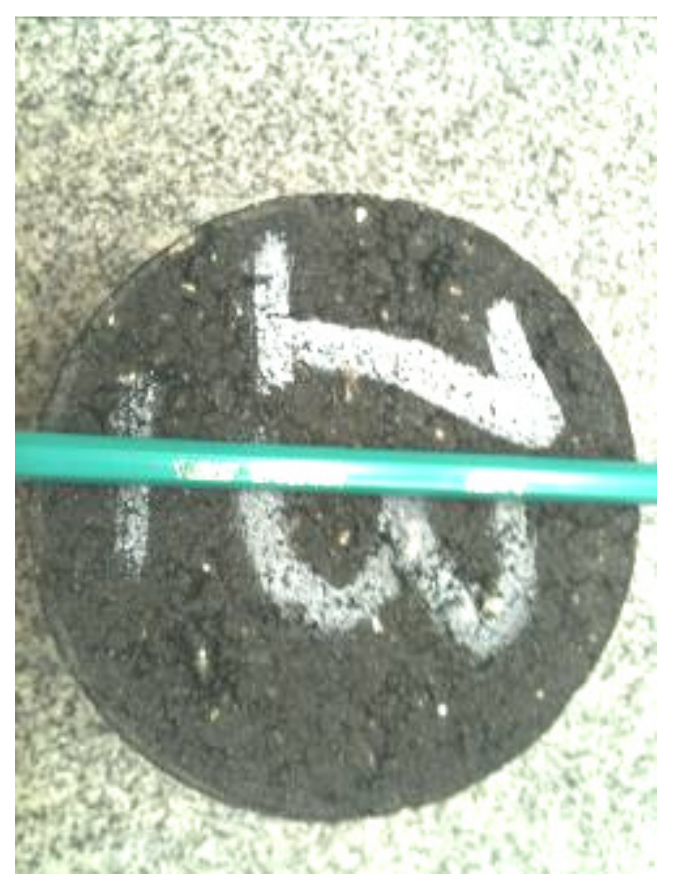

c) CP de mistura de módulo elevado resultante do ensaio de fadiga de compressão diametral na MTS

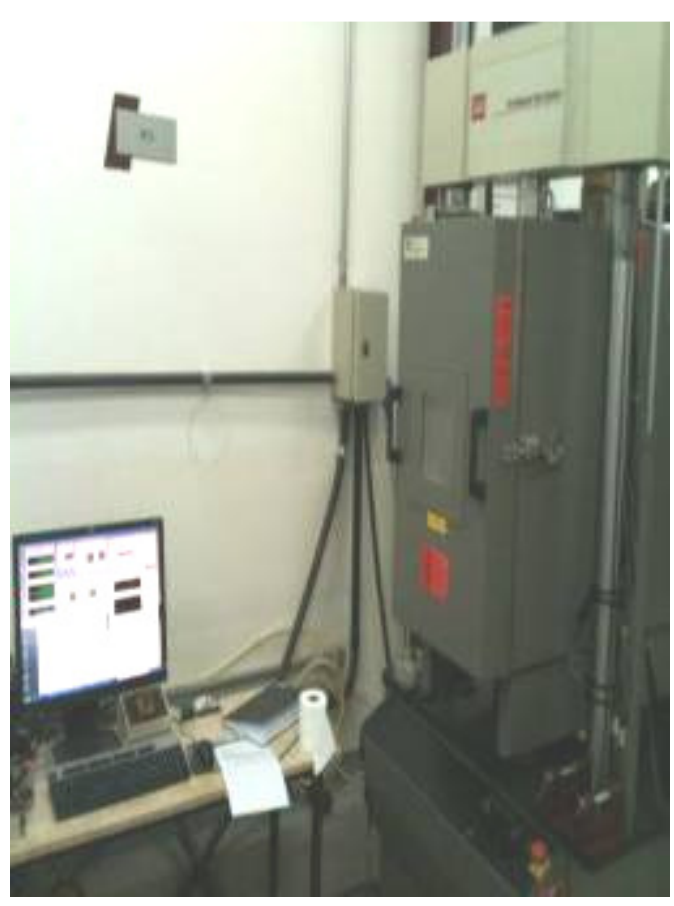

b) Software para obtenção de dados durante ensaio de fadiga de compressão diametral com câmara de controle de temperatura na MTS

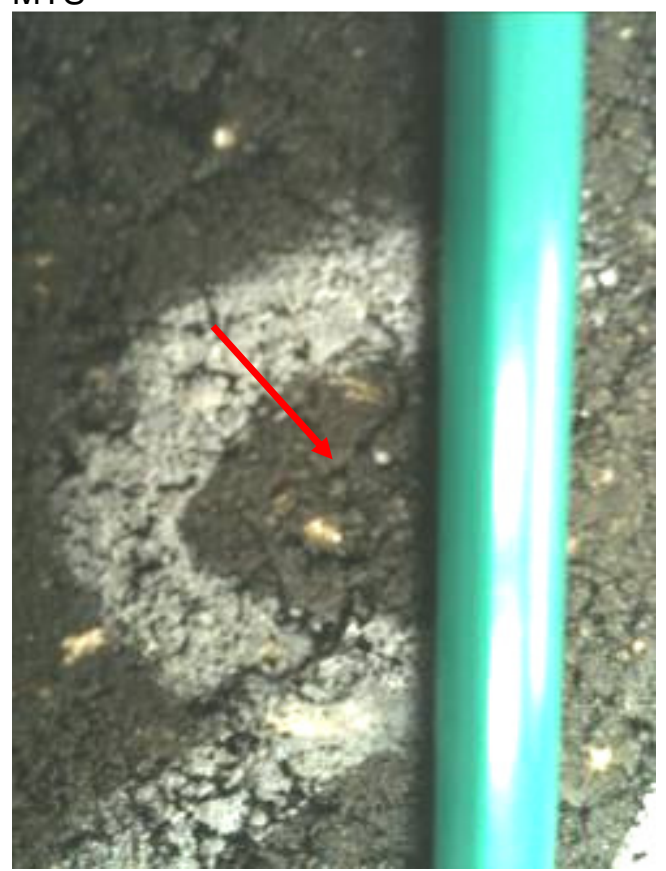

d) Trinca resultante do ensaio de fadiga de compressão diametral em CP de mistura de módulo elevado

Figura 45 - Ensaio de fadiga de compressão diametral, LTP-USP

O ensaio de fadiga diametral foi realizado com os corpos-de-prova cilíndricos provenientes da dosagem Marshall, moldados no teor ótimo de projeto. Nestes ensaios, também procurou-se comparar o comportamento dos CAPs A e B com o 
CAP 30/45, e esperava-se que as misturas compostas por CAP de baixa penetração e portanto de módulo elevado apresentassem vida de fadiga superiores a vida de fadiga do CAP 30/45. A Figura 46 demonstra o resultado deste ensaio.

Um estudo mecanístico é necessário para avaliação do bom comportamento das misturas de módulo elevado. Pois não se pode comparar diretamente misturas com características de rigidez e módulos de resiliência distintas, uma vez que estas características podem influenciar na resistência à tração da fibra inferior, na deformação e na deflexão de uma estrutura. Pode-se observar que o resultado esperado foi atingido, muito embora o CAP A não possa ser considerado um CAP para misturas de módulo elevado. Ele não apresentou valores de módulo de resiliência conforme o recomendado, mas em certos níveis de tensões ele se comportou melhor quando comparado com a mistura de CAP 30/45 em estudo. Quanto ao CAP B, é evidente o seu melhor comportamento com relação ao ensaio de fadiga por compressão diametral quando comparado com as duas outras misturas em estudo, reinterando mais uma vez o melhor comportamento mecânico de mistura de módulo elevado quando comparada com uma mistura com CAP convencional.

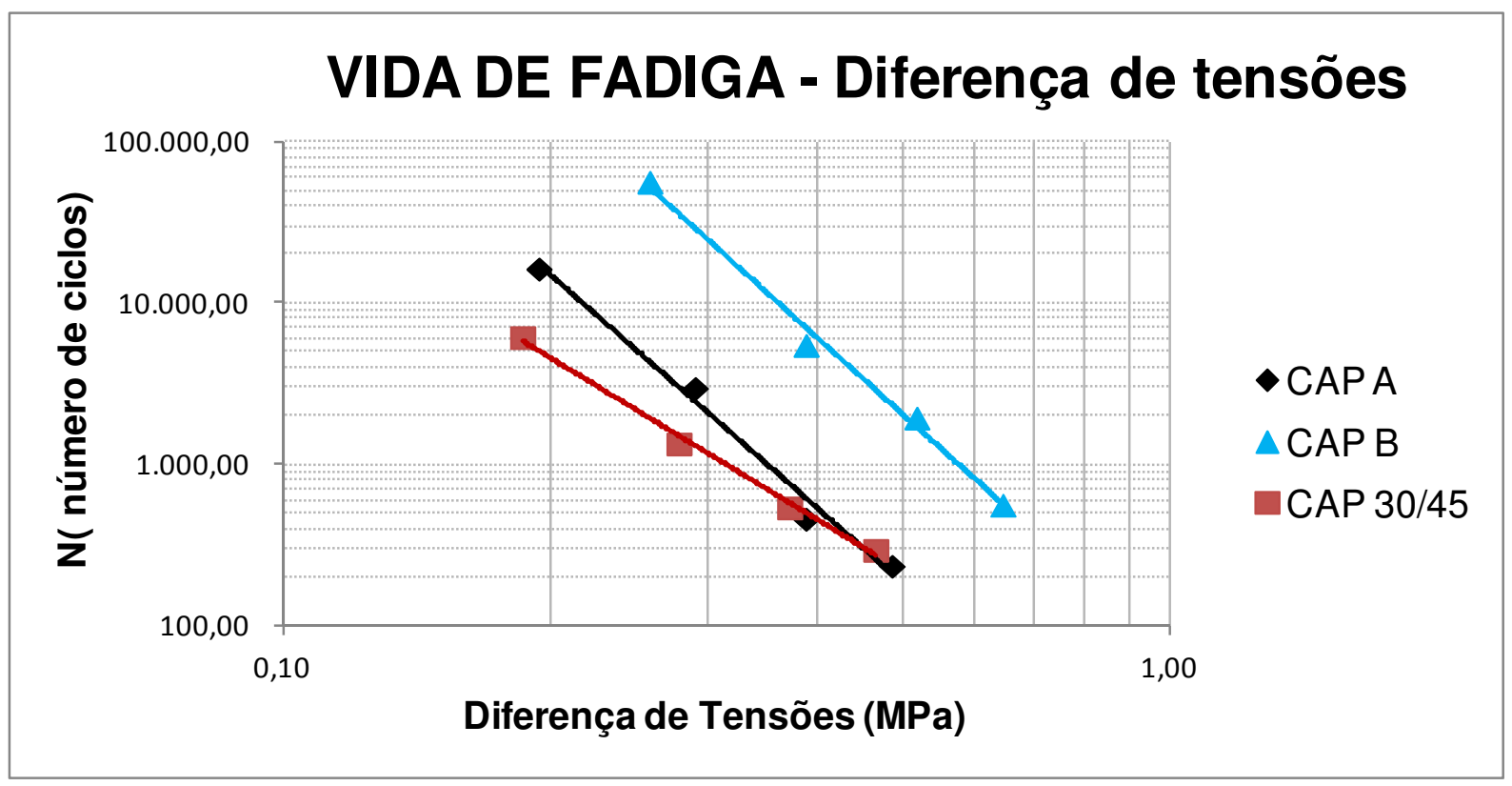

Figura 46 - Resultados do ensaio de fadiga por compressão diametral - tensão controlada 


\subsubsection{Fadiga por flexão em ensaio de viga com 4 pontos}

O ensaio de fadiga por flexão em ensaio de viga com 4 pontos foi realizado no laboratório do Centro de Pesquisas Rodoviárias - CPR NovaDutra. Este ensaio foi realizado à deformação controlada conforme critérios estabelecidos na norma americana AASHTO - T321/2003, Determining the Fatigue Life of Compacted HotMix Asphalt (HMA) Subjected to Repeated Flexural Bending. Foram adotadas 3 deformações para determinação da curva de fadiga dos CAPs empregados (CAP A e CAP B e CAP convencional 30/45). Para cada deformação, foram ensaiadas 3 vigotas conforme recomendado na norma para determinação do resultado por meio da média aritmética. A vigota para o ensaio de fadiga de 4 pontos está representada pela Figura 47. A Figura 48 mostra o equipamento e a instrumentação da vigota empregada no ensaio de fadiga por flexão de viga com 4 pontos. As vigotas foram extraídas de um único bloco de dimensão de $150 \mathrm{~mm} \times 450 \mathrm{~mm} \times 150 \mathrm{~mm}$, moldado na mesa compactadora PressBox localizada no Centro de Pesquisas RodoviáriasCPR. Nesta mesa, a mistura é colocada, e através e um sistema computacional, estima-se o número de giros necessários para sua compactação. A compactação é feita por amassamento através de duas placas retangulares horizontais instaladas na extremidade inferior e superior do molde. Após a compactação do molde esperase $24 \mathrm{~h}$ para desmoldar, e, posteriormente, efetuar o corte das vigotas para o ensaio de fadiga por flexão de 4 pontos. Cada prisma resulta em 4 vigotas para o ensaio.

As vigotas tem dimensões de $63 \mathrm{~mm} \times 380 \mathrm{~mm} \times 50 \mathrm{~mm}$ e devem apresentar-se homogêneas $e$ isentas de indícios de segregação bem como irregularidades superficiais. O corte do prisma para moldar as vigotas deve ser feito com cautela evitando imperfeições e irregularidades na sua superfície, caso contrário o ensaio pode ser prejudicado ou mesmo interrompido pelo rompimento precoce da vigota. É de extrema importância o controle do volume de vazios das vigotas, principalmente do conjunto a ser ensaiado em cada deformação. Todas as vigotas devem apresentam volume de vazios semelhantes, pois valores divergentes resultam em comportamento distintos no ensaio e podem interferir no resultado final da vida de 
fadiga de uma mistura. As misturas usinadas com CAP A, CAP B e CAP 30/45 apresentaram volume de vazios médio de $2,6 \%, 2,9 \%$ e $3,5 \%$ respectivamente.

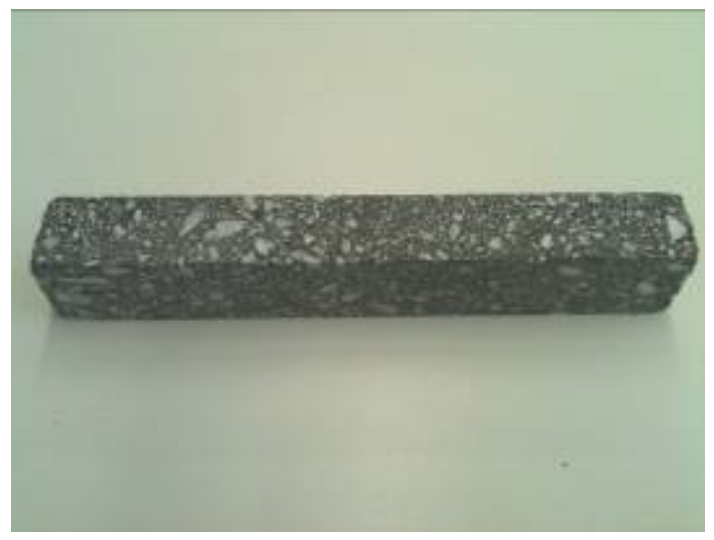

Figura 47 - Vigota para ensaio de fadiga por flexão de 4 pontos

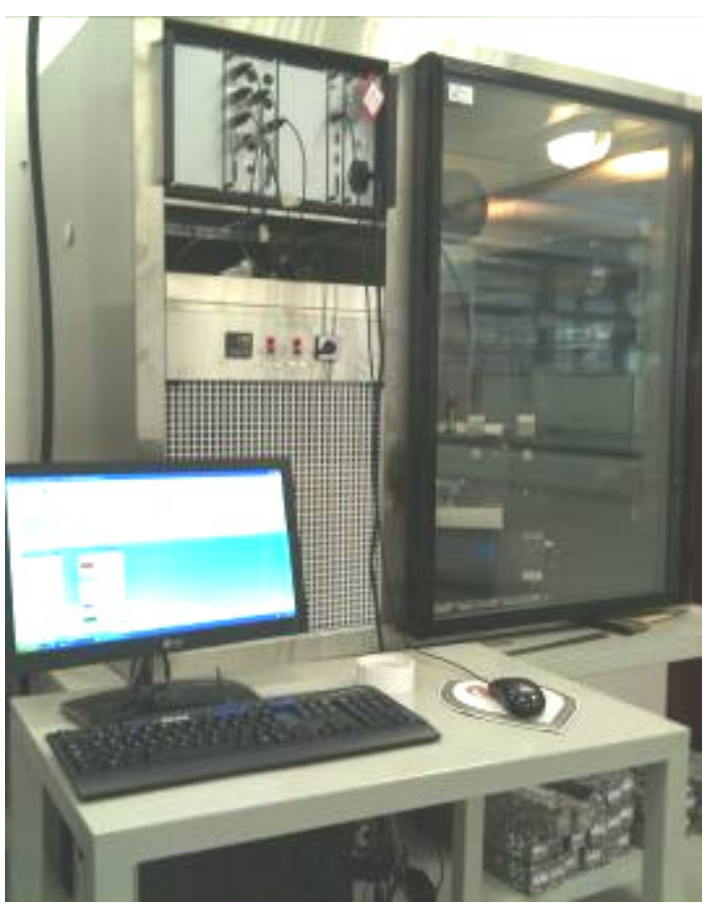

a) Equipamento e software para realização do ensaio de fadiga por flexão de viga de 4 pontos

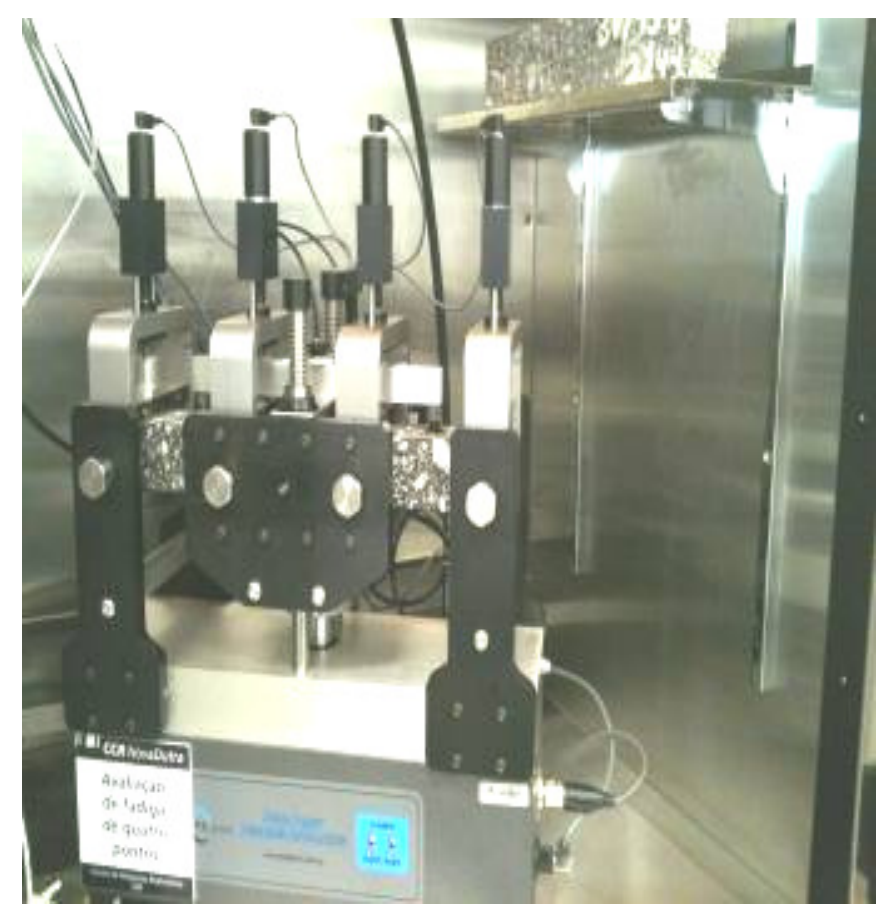

b) Instrumentação da vigota no equipamento de fadiga por flexão de viga de 4 pontos

Figura 48 - Equipamento e instrumentação para ensaio de fadiga por flexão de 4 pontos

O ensaio foi realizado das deformações de 300, 500 e 800 microstrain. O critério de parada considerado foi de $50 \%$ de redução da rigidez inicial. Os resultados deste ensaio encontram-se na Figura 49. Neste ensaio pode-se notar o melhor comportamento da misturas asfáltica com o CAP A, enquanto que a mistura com CAP B, quando comparada com a mistura convencional, apresentou resultados de 
número de ciclos inferior. Neste ensaio, a mistura com o CAP A apresentou um melhor comportamento, no entanto, assim como no estudo de fadiga por compressão diametral, não se pode deixar de mencionar a necessidade de um estudo mecanístico com base em uma estrutura de pavimento. Não se pode estabelecer uma comparação direta apenas com os resultados destes ensaios uma vez que há comparação entre misturas com características de rigidez distintas. Os ensaios de fadiga servem para subsidiar os critérios que devem ser adotados para uma análise estrutural de pavimento. A Figura 50 mostra o resultado de uma vigota após o ensaio de fadiga de 4 pontos proveniente de mistura de módulo elevado com o CAP A.

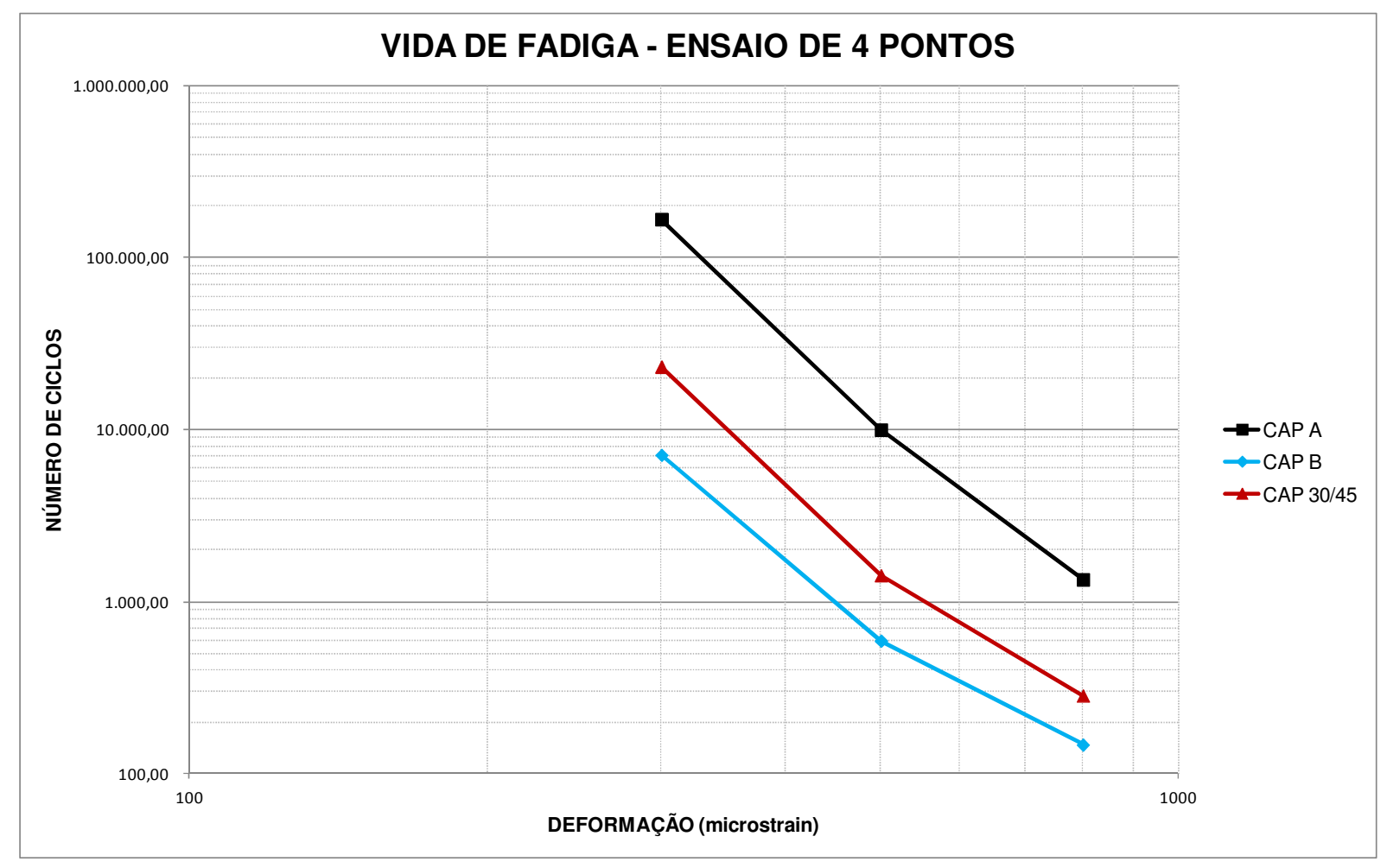

Figura 49 - Resultados do ensaio de fadiga por flexão em viga de 4 pontos - deformação controlada 


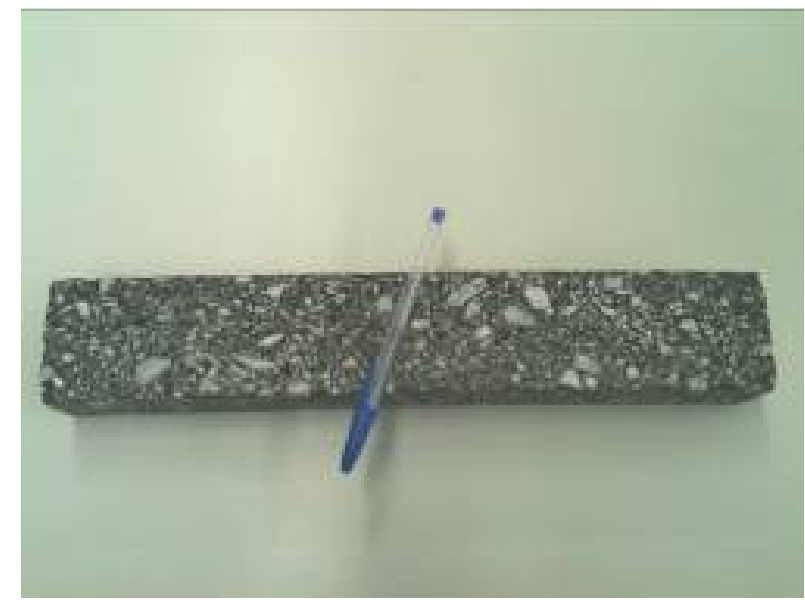

a) Vigota da mistura com o CAP A após ensaio de fadiga de 4 pontos

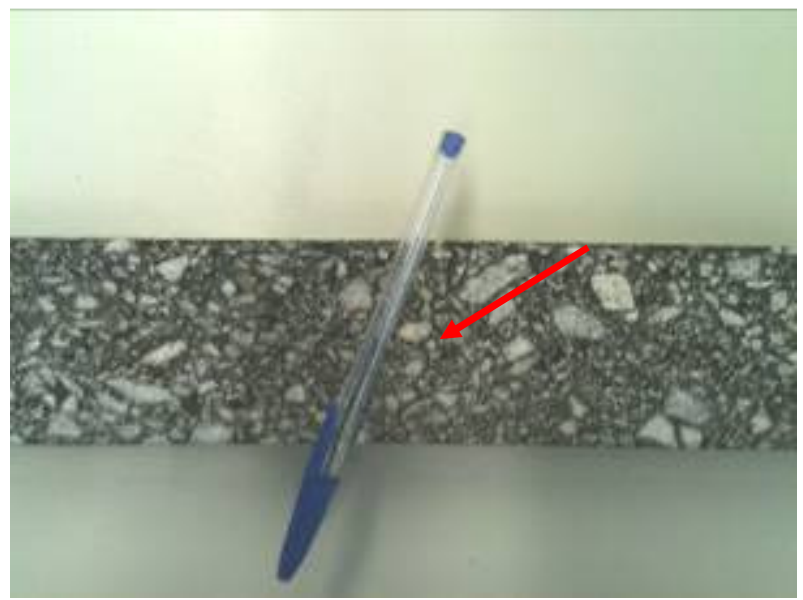

b) Vista aproximada da trinca obtida após ensaio de Fadiga de 4 pontos

Figura 50 - Vigota de mistura asfáltica de módulo elevado após ensaio de fadiga por flexão de 4 pontos

\subsubsection{Análise comparativa entre os métodos de fadiga}

Neste estudo, adotou-se o ensaio de fadiga por compressão diametral à tensão controlada e de fadiga por flexão de 4 pontos à deformação controlada. Estes são ensaios com características distintas e, portanto, devem ser avaliados separadamente, uma vez que o ranqueamento das misturas é dependente do modo de carregamento.

Segundo Ghuzlan (2001), quanto maior o valor da viscosidade de uma material, maior é sua vida de fadiga no ensaio a tensão controlada e menor é sua vida de fadiga no ensaio a deformação controlada. Comparando os resultados de fadiga obtidos para o CAP B, de maior viscosidade, e para o CAP 30/45, pode-se observar que no ensaio de fadiga à tensão controlada o CAP B apresentou um melhor comportamento quando comparado com o CAP 30/45, enquanto no ensaio à deformação controlada o CAP 30/45 de menor viscosidade apresentou melhores resultados. 
Nesta pesquisa, desenvolveu-se o estudo de materiais (agregado e ligante) e de misturas asfálticas de módulo elevado empregando-se dois asfaltos duros, de penetração entre 10 e 20. Foi adotada na pesquisa uma única curva granulométrica que atendeu a faixa denominada EME0/14, comumente empregada para misturas de módulo elevado na França. Foram realizados ensaios para a dosagem das misturas e para a determinação de propriedades como: deformação permanente, resistência à tração indireta, módulo de resiliência, módulo dinâmico e de vida de fadiga. Os resultados das duas misturas de módulo elevado foram analisados e comparados com uma mistura asfáltica de granulometria similar, mas usinada com CAP 30/45, que é o CAP convencional de menor penetração disponível no mercado.

A pesquisa teve o objetivo atingido, uma vez que a sequência de ensaio proposta foi realizada, principalmente no que se refere à determinação do módulo de resiliência, obtido por meio de dois equipamentos distintos (MTS e UTM), à deformação permanente das misturas asfálticas e aos ensaios de fadiga com características distintas (fadiga por compressão diametral e fadiga por flexão de 4 pontos).

Para melhor compor a estrutura do trabalho, uma análise mecanística, com base nos resultados dos ensaios de fadiga das misturas asfálticas empregadas nesta pesquisa, pode ser executada no futuro. As misturas asfálticas em estudo apresentaram valores de rigidez distintos e, portanto, não devem ser diretamente comparadas.

Uma análise mecanística, considerando os valores de módulos de resiliência e as curvas de fadiga encontradas, pode ser elaborada para melhor avaliar 0 comportamento das misturas estudadas, com relação às diferentes propostas de estruturas de pavimento a ser aplicada em campo. Somente após esta análise é possível orientar sobre a melhor aplicabilidade de cada mistura asfáltica. 
Durante 0 desenvolvimento desta pesquisa, algumas dificuldades foram encontradas, assim, aconselha-se atentar para:

- A granulometria dos agregados estudada neste trabalho é contínua e bem graduada com presença de finos, o que possibilita sua utilização dentro de uma faixa (EME 0/14) utilizada para módulo elevado, adotada de experiências anteriores. Em paralelo ao estudo da composição da granulometria, é importante que o ligante asfáltico seja conhecido, pois ligantes duros podem ter modificadores em sua composição.

- A análise dos agregados pelo Método Bailey resultou em uma combinação com valores de CA e FAf dentro dos limites estabelecidos na literatura, enquanto que o valor FAc excedeu em 0,06 o limite superior recomendado para o tamanho máximo nominal de $9,5 \mathrm{~mm}$, que mostra um indício da necessidade de melhor compactação da fração miúda da mistura. Não há diretrizes específicas da utilização do método Bailey para granulometria de misturas de módulo elevado. Neste trabalho optou-se por representar apenas a verificação por este método a título de conhecimento e abertura de novas possibilidades para futuras experiências, uma vez que um bom esqueleto pétreo contribui para um melhor desempenho em campo das misturas asfálticas.

- A condição do corpo-de-prova, homogeneidade da mistura, volume de vazios semelhantes das amostras e instrumentação adequada e padronizada para todas as amostras é de extrema importância para não comprometimento dos ensaios de fadiga. No caso destes critérios não serem adotados, os resultados dos ensaios podem apresentar grande variabilidade e prejudicar a análise das misturas asfálticas, uma vez que amostras fora da média devem ser descartadas. É importante também que seja definido e mencionado os critérios de dano (ou de ruptura) para uma melhor avaliação e comparação das misturas estudadas.

- Os critérios de parada dos ensaios de fadiga devem ser bem avaliados, para que este ensaio não seja interrompido prematuramente. O elevado tempo de ensaio de fadiga das amostras, principalmente as produzidas com ligantes 
asfálticos duros podem inviabilizar a continuidade e muitas vezes o término do ensaio.

Os estudos e as análises levaram às seguintes conclusões:

- Com relação aos ligantes pode-se concluir que os ligantes A e B apresentam características de ligantes duros, ou seja, baixa penetração, viscosidade mais alta e maior ponto de amolecimento quando comparada com o ligante convencional. No entanto, somente estas características não são suficientes para determinação de um ligante capaz de produzir uma mistura de módulo elevado. É necessário, dentre outros, o estudo reológico dos ligantes asfálticos.

- Os ensaios reológicos realizados no ligante virgem apontaram possíveis resultados de PG altos a alta temperatura, para os dois asfaltos, CAP A e CAP B estudados. Neste trabalho pode-se notar que os ligantes avaliados, apesar da semelhança no resultado de penetração, apresentaram características reológicas muito distintas, salientando a importância da realização de ensaios complementares no ligante e não somente os ensaios de caracterização tradicional.

- Os ensaios de MSRC apresentaram resultados diferentes para o CAP A, sendo que o mesmo apresentou um percentual de recuperação maior em relação ao CAP B. Este ensaio mostra que a caracterização por penetração e ponto de amolecimento, além da viscosidade rotacional, não identificam com o rigor necessário o comportamento dos ligantes asfálticos duros. Comparando-se os parâmetros $\mathrm{G}^{*}$ e $\delta$, o CAP B apresentou maiores valores de ângulo de fase do que o CAP A. Considerando a caracterização feita dentro do regime viscoelástico linear, quanto maior o ângulo de fase, o comportamento viscoso é mais preponderante, sendo que neste estudo o CAP $B$ é menos elástico que o CAP A. Em termos de nível de tráfego e variação de temperatura (de $52^{\circ} \mathrm{C}$ a $76^{\circ} \mathrm{C}$ ), o CAP A é o que suporta o maior tráfego em todas as temperaturas analisadas. O CAP B suporta tráfegos gradativamente menores à medida que aumenta a temperatura do pavimento, 
enquanto que o CAP $30 / 45$ atende ao tráfego pesado a $64^{\circ} \mathrm{C}$ e ao padrão a $70^{\circ} \mathrm{C}$.

- As dosagens Marshall e SUPERPAVE apresentaram teores de projeto bem próximos para ambos os CAPs para as misturas de módulo elevado, CAP A e CAP B, apesar de haver certa similaridade nos dois métodos para as misturas empregadas neste trabalho, o Método Marshall aponta para resultados ligeiramente superiores ao SUPERPAVE. Foram encontrados valores de dosagem Marshall e Superpave para o CAP A de 5,5\% e 5,3\% respectivamente; para o CAP B, teores de 4,8\% e 4,5\%, respectivamente; e para o CAP 30/45, teores de 4,8\% e 4,6\%, respectivamente. A mistura com CAP A apresentou um teor mais elevado devido à elevada viscosidade deste ligante.

- Os volumes de vazios obtidos nos corpos de prova preparados na compactação pela PCG atenderam as exigências da especificação francesa de misturas de módulo elevado, para os dois CAPs duros do estudo, sendo ambos menores que 6\% para 100 giros, conforme recomendação francesa.

- O ensaio de dano por umidade induzida para o CAP A atendeu às especificações apresentando um valor de $86,6 \%$, superior ao limite normativo de $75 \%$. Para o CAP B houve necessidade de empregar um melhorador de adesividade. O ensaio foi repetido com adição de cal à mistura e posteriormente com adição de dope ao ligante, antes da misturação. Com a incorporação dos melhoradores de adesividade, foi atendido o limite normativo do dano por umidade induzida. Dessa forma, recomenda-se um estudo laboratorial do comportamento desta mistura com relação aos ensaios mecânicos, preliminar à aplicação em campo.

- Os resultados de deformação permanente atenderam ao esperado para todos os CAPs avaliados (CAP A, CAP B e CAP 30/45). Neste ensaio, pode-se notar o melhor comportamento de ligantes denominados para módulo elevado quando comparados com o ligante convencional. A diferença obtida entre os ligantes para módulo elevado e o ligante convencional foi de 1,3\%. Todos 
encontram-se com valores de afundamentos inferiores ao limite europeu de $7,5 \%$ para 30.000 ciclos no simulador francês tipo LCPC.

- Os resultados de módulo de resiliência atenderam a expectativa de módulo próximos a $10.000 \mathrm{MPa}$ a $25^{\circ} \mathrm{C}$, para o CAP B. O CAP A, embora tenha apresentado características e comportamento na deformação permanente semelhante a um ligante para misturas de módulo elevado, não apresentou um módulo de resiliência alto. Os módulos encontrados para o CAP A foram de aproximadamente $4.900 \mathrm{MPa}$, enquanto que para o CAP $B$ foram de 10.600MPa. O CAP 30/45 convencional apresentou módulos da ordem de $5.400 \mathrm{MPa}$.

- Com relação ao ensaio de módulo dinâmico pode-se notar comportamento semelhante entre os CAPs B e 30/45. Esta proximidade entre suas curvas mestras está relacionada ao fato dos dois CAPs apresentarem valores de viscosidade mais próximos. Com relação à mistura elaborada com o CAP A, pode-se concluir que este ligante é menos sensível ao efeito da variação de frequência e de temperatura. Esta característica é também observada em asfaltos modificados, pois a misturas asfálticas com adição de ligante modificado tende a ter uma maior estabilidade. Esta análise pode ser comprovada através do ensaio de recuperação elástica feito no ligante, no ensaio de MSCR. O CAP A apresentou maior recuperação elástica e, portanto menos sensibilidade à variação de frequência e temperatura conforme curva mestra obtida no ensaio de módulo dinâmico.

- Com relação aos ensaios de fadiga, comparativamente, o CAP B, que apresenta maior rigidez que o CAP 30/45, no ensaio de fadiga por compressão diametral à tensão controlada, resultou em um melhor comportamento que a mistura com CAP 30/45. Porém no ensaio de fadiga por flexão de 4 pontos à deformação controlada obteve-se o ranqueamento inverso.

Com o objetivo de complementar os trabalhos existentes sobre o comportamento de misturas de módulo elevado para camadas de base de pavimento e melhor avaliar a aplicabilidade destas misturas no país, tem-se como sugestão para futuros trabalhos: 
- Avaliar a característica e o comportamento de diferentes agregados em misturas asfálticas de módulo elevado para uma mesma faixa granulométrica de trabalho;

- Comparar ensaios laboratoriais de misturas de módulo elevado com diferentes faixas de trabalho: EME 0/10, EME0/14 e EME0/20.

- Estudar a influência de diferentes modificadores de ligante asfáltico no comportamento mecânico das misturas de módulo elevado.

- Aprofundar os ensaios de caracterização dos ligantes utilizados para misturas de módulo elevado, com intuito de melhor compreender o comportamento destas misturas com relação aos ensaios mecânicos, principalmente módulo de resiliência e/ou módulo dinâmico.

- Realizar estudos sobre a fadiga dos ligantes asfálticos empregados em misturas de módulo elevado no país, bem como seu processo de envelhecimento de curto e longo prazo.

- Aprofundar estudo de fadiga para misturas de módulo elevado: determinação de equações de fadiga e simulação de estruturas que apresentem melhor desempenho mecânico para este tipo de mistura.

- Executar trechos experimentais com misturas de módulo elevado como camada de base de pavimento, previamente estudas em laboratório, para monitoramento e realização de banco de dados relacionado ao desempenho obtido com este tipo de mistura em escala real.

- Analisar financeiramente o uso de misturas de módulo elevado como camada de base de pavimento, bem como sua vida útil. Avaliar o custo de execução e manutenção desta estrutura.

- Reunir sugestões para criação de especificações técnicas de ensaios laboratoriais, aplicação e controle em campo de misturas de módulo elevado no país. 


\section{REFERÊNCIAS}

AASHTO - American Association of State Highway and Transportation Officials. T321:Determining the Fatigue Life of Compacted Hot-Mix Asphalt (HMA) Subjected to Repeated Flexural Bending, 2003.

.. T209: Theoretical maximum specific gravity and density of bituminous paving mixtures;, 2005.

Washington, 2009.

.. M320: Standard Specification for Performance-Graded Asphalt Binder. damage:; 2010.

T283: Resistance of compacted asphalt mixtures to moisture induced

ABNT - Associação Brasileira de Normas Técnicas. NBR 12052: Solo ou agregado miúdo - Determinação do equivalente de areia. Rio de Janeiro, 1992.

.NBR 12891: Dosagem de misturas betuminosas pelo método Marshall Procedimento. Rio de Janeiro,1993.

. NBR NM51: Ensaios abrasão “Los Angeles”. Rio de Janeiro, 2001.

. NBR 6296: Produtos Betuminosos semi-sólidos - Determinação da massa específica e densidade relativa. Rio de Janeiro, 2004. 
.NBR 15184: Materiais Betuminosos - Determinação da viscosidade em temperaturas elevadas usando um viscosímetro rotacional. Rio de Janeiro, 2004.

.. NBR 7809: Agregado Graúdo - Determinação do índice de forma pelo método do paquímetro. Rio de Janeiro, 2006. Janeiro, 2007.

.NBR 6576: Materiais Asfálticos - Determinação da penetração. Rio de .. NBR 6560: Materiais Betuminosos - Determinação do ponto de amolecimento - Método do anel e bola. Rio de Janeiro, 2008.

.NBR 15617: Determinação do dano por umidade induzida. Rio de Janeiro, 2011.

.NBR 9935: Agregado. Rio de Janeiro, 2011.

.NBR 15087: Determinação de resistência à tração por compressão diametral, 2012.

AFNOR - Association Française de Normalisation. NF $P$ 98-273-1: Déformation permanente des mélanges hydrocarbonés: partie I: essai d’oniérag. Paris, 1991a.

NF P 98-250-2: Préparation des mélanges hydrocarbonés: partie II: compactáge des plaque. Paris, $1991 \mathrm{~b}$.

.. NF P 98-252: Essais relatifs aux chaussées: Détermination du comportement au compactage des mélanges hydrocarbonés: Essai de compactage à la presse à cisaillement giratorie (PCG), Paris, 1999a. 
.NF P 98-140: Enrobés Hydrocarbonés: Couches d’assises: enrobé à module élevé EM, Paris, 1999.

.EN 13924- Bitumes et liants bitumineux-Spécifications des bitumes routies de grade dur, 2006.

.EN12697: Méthodes d'essai pour mélange hydrocarboné à chau, 2008.

ASTM - American Society for Testing and Materials. D3497: Standard Test method for Dynamic Modulus of Asphalt Mixture, 2003.

.D2872: Standard test method for effect of heat and air on a moving film of asphalt (Rolling Thin-Film Oven Test, 2004.

. D7175:Standad test method for determining rheological properties of asphalt binder using a dynamic shear rheometer, 2008.

.. D 7369: Standard test method for determining the resilient modulus of bituminous mixtures by indirect tension test, 2009.

. D7405: Standard test method for multiple stress creep and recovery (MSCR) of asphalt binder using a dynamic shear rheometer, 2010a.

AVIS TECHNIQUE - Comite Français pour lês techniques routieres: Compodule $H$, Chaussees 133, 2002. 
BALBO, J. T.; BODI, J. Reciclagem a quente de misturas asfálticas em usinas: asternativas de bases e elevado módulo de elasticidade, XVIII ANPET - XVIII Congresso de pesquisa e ensino em transportes, 2004.

BALBO, J. T. Pavimentos de concreto, São Paulo, 2009.

BARRA, B.S. Avaliação da água no módulo complexo e na fadiga de misturas asfálticas densas. Tese de Doutorado, Universidade Federal de Santa Catarina, 2009.

BERNUCCI, L.B; LEITE, L.F.M; CERATTI,J.A.P.; MOURA,E. Asfalto Modificado com EVA: solução para revestimentos asfálticos de alto módulo e alta resistência à deformação permanente. In: 32ª Reunião Anual de Pavimentação, Brasília, 2000.

BERNUCCI, L.B; MOTTA, L.M.G.; CERATTI,J.A.P.; SOARES, J.B. Pavimentação Asfática: Formação Básica para Engenheiros. Rio de Janeiro, 2008.

BROSSEAUD, Y. Les enrobés Français: Panorama des techniques bitumineuses, bilan de comportement. $16{ }^{\circ}$ Encontro do Asfalto. Rio de Janeiro, 2002.

CAPITÃO, S. D. Caracterização mecânica de misturas betuminosas de alto módulo de deformabilidade. Tese de doutorado, Universidade de Coimbra, 2003.

CAVALCANTI, L. S. Efeito de alguns modificadores de ligante na vida de fadiga e deformação permanente de misturas asfálticas, Coordenação de Programas de Pós Graduação em Engenharia, Universidade Federal do Rio de Janeiro-COPPE/UFRJ, Rio de Janeiro, 2010.

CONTRAN - Conselho Nacional de Trânsito. Resolução 258 - Regulamento os artigos 231, X e 323 do código de trânsito brasileiro , fixa metodologia de aferição de peso de veículos, estabelece percentuais de tolerância e dá outras providências. Código de Trânsito Brasileiro,2007. 
CONI, M.; PORTAS, S.; ISOLA, R.; OLIVEIRA, J.R.M. FE Evaluation of 4-point bending test for fatigue cracking assessment. Transportation Research Board, 2008.

CNT - Confederação Nacional dos Transportes. Pesquisa Rodoviária 2011: Relatório Gerencial. Disponível em: http://www.cnt.org.br/, acesso em 15 de agosto de 2012.

CORTÉ, J.F. Development and uses of hard grade asphalt and of hight modulus asphalt mixes in France. Transportation Research Circular: Perpetual Bituminous Pavements, Washington, 2001.

DELORME, J.; ROCHE, C.; WENDLING, L. Manuel LCPC d'aide à formulation des enrobes. Laboratoire central desponts et chausses, Paris, 2007.

DNER - Departamento Nacional de Estradas de Rodagem. ME 133: Misturas Betuminosas: determinação de módulo de resiliência. Rio de Janeiro, 1994.

Janeiro, 1994.

ME138: Mistura Asfáltica - Determinação da resistência a tração. Rio de .Manual de Pavimentação, Publicação IPR 719. Departamento Nacional de Infraestrutura dos Transportes, Rio de Janeiro, 1996.

.ME054: Equivalente de areia, Rio de Janeiro, 1997.

DENNEMAN, E.; NKGAPELE, M.; BOATENG, J. A.; MAINA, J. W. Transfer of hight modulus asphalt technology to South Africa, 10th Conference on asphalt pavements for Southern Africa, 2011. 
DISTIN, T..; SAMPSON, L.; MARAIS, H.; VERHAEGE, B. Hight modulus asphalt: assessment of viability based on outcomes of overseas fact finding mission, 10th Conference on asphalt pavements for Southern Africa, 2011.

FONTES, L.P.T.L.; TRICHÊS, G.; PEREIRA, P.A.A.; PAIS, J.C. Influência da temperatura na resistência à fadiga de misturas asfálticas com asfalto borracha, 2010,:http://www.anpet.org.br/ssat/interface/content/autor/trabalhos/publicacao/2010/ 419_AC.pdf, acesso em 20/07/2012.

FONTES, L.P.T.L.; TRICHÊS, G.; PEREIRA, P.A.A.; PAIS, J.C. Comportamento à fadiga e à deformação permanente de misturas asfálticas confeccionadas com asfalto-borracha brasileiro. Universidade do Minho, Portugal, 2008. http://repositorium.sdum.uminho.pt/handle/1822/17217, acesso em 15/08/2012.

FREITAS, H. B. Misturas Asfálticas de Módulo Elevado com uso de Escória de Aciaria como Agregado. Tese de mestrado, Universidade Federal do Rio de Janeiro, 2007.

GHUZLAN, K. A. Fatigue damage analysis in asphalt concrete mixtures based upon dissipated energy concepts. Tese de doutorado, Universidade de Illinois, Urbana, 2001.

HU, S.; ZHOU F.; HU, X.; SCULLION, T.; QI. X.; WALUBITA, L.F.e CLAROS G. Consideration of HMA resilient modulus (MR) for M-E pavement design and analysis. Journal of the association of asphalt pavement technologist, Philadelphia, 2008.

INSTITUTO DO ASFALTO Manual de Asfalto, série do manual no 4 (MS-4), 1989 revisado em 2002.

KIM, Y. R. ; UNDERWOOD, S.; MUN, S.; GUDDATI, M. N. - Perpetual pavement evaluation using the viscoelastic continuum damage finite element program, International Conference on Perpetual Pavement, 2006. 
LEE, H. J.; LEE, J. H.; PARK. H. M. Performance evaluation of hight modulus asphalt mixtures for long life asphalt pavements, Construction and Building Materials, 2006.

LEITE,L.M.; NASCIMENTO, A.A.H.; CHACUR, M.; MARTINS,A. T.; ROCHA, S.M.N.; FIGUEIREDO,U. - Empregos de asfaltos duros em rodovias de alto volume de tráfego, Basvias,2011.

LESEUR, D. Panoramica francesa de las mezclas bituminosas desarrollos recientes, Info AEC boletín informativo - Associación Española de la Carreteras, 2005.

LOUREIRO, T. G. Estudo da Evolução do Dano por Fadiga em Misturas Asfálticas. Tese de Mestrado, Universidade Federal do Ceará, 2003.

MAGALHÃES, S. T. Misturas Asfálticas de Módulo Elevado para Pavimentos de Alto Desempenho. Tese de Mestrado, Coordenação de Programas de Pós Graduação em Engenharia, Universidade Federal do Rio de Janeiro-COPPE/UFRJ, Rio de Janeiro, 2004.

MAUPIN, G. W. e DIEFENDERFER, B. K. Design of a high binder - high modulus asphalt mixture. Virginia Transportation Research Council, Charlottesville-VA, 2006.

NEWCOMB, D.; HANSEN, K. R. Mix type selection for perpetual pavements, 2010, http://www.ohio.edu/, acesso em 15/01/2012 .

PAIS, J.C.; FONTES, L.P.T.L.; PEREIRA, P.A.A.; MINHOTO, M.J.C.; KUMAR, D.S.N.V.A.; SILVA, B.T.A. Analysis of the variation in the fatigue life throught fourpoint bending tests. Four Point Bending proceedings of the second workshop, Universidade do Minho, 2009. 
PERRET, J.; DUMONT, A.G.; TURTSCHY - Assessment of resistance to rutting of high modulus bituminous mixtures using full scale accelerated loading tests, 3rd Euroasphalt \& Eurobitume Congress Vienna, 2004.

PIARC - XTH INTERNATIONAL WINTER ROAD CONGRESS IN LULEAA, SWEDEN , Volume: 1, Publisher: Swedish National Road and Transport Research Institute (VTI), 1998.

PINTO, S.; PREUSSLER, E. Pavimentação Rodoviária- Conceitos fundamentais sobre Pavimentos Flexíveis. Rio de Janeiro, 2002.

QUINTERO, C.A.Q. Estudos de misturas asfálticas com ligantes de consistência elevada: Formulação e comportamento mecânico. Tese de mestrado, Universidade Federal de Santa Catarina, 2011.

REDE TEMÁTICA DO ASFALTO Manual de execução de trechos monitorados, 2010.

ROHDE, L. Estudo de Misturas Asfálticas de módulo elevado para camadas estruturais de pavimento. Tese de doutorado, Universidade Estadual do Rio Grande do Sul, Porto Alegre, 2007.

SETRA e LCPC - Service d'éstudes techniques des routes et autoroutes e laboratorie central des ponts et chaussées. Catalogue dês structures types de chaussées neuves. Bagneux: Ministère de L`Equipement, des Transports et du Logement, 1998.

SUPERPAVE FUNDAMENTALS, Reference manual.I Department of Transportation, Federal Highway Administration, llinois, http://www.dot.state.il.us/blr/ p028.pdf, acesso em 11/08/2012. 
VAVRIK, W. R.; HUBER, G.; PINE, W. J.; CARPENTER, S. H.; BAILEY, R. Bailey Method for Gradation Selection in HMA Mixture Design. Transportation Research Board, 2002.

VILLELA, A.R.A.; BERNUCCI, L.L.B.; DIAS, C.R.C., SUSUKI, C.Y.; ESCUDEIRO, M.S. Camada de base asfáltica de módulo elevado para restauração de rodovias de tráfego pesado: a primeira experiência no Brasil em escala real. $7^{a}$ Exposição Internacional de Produtos para Rodovias, BRASVIAS, 2011.

VILLELA, A.R.A.. Estudo de camada de base asfáltica de módulo elevado para restauração e rodovias de tráfego muito pesado. Tese de doutorado, Escola Politécnica da Universidade de São Paulo-Poli, USP, São Paulo, 2012.

YANG,Y; GAO,X.; LIN, W. Perpetual Pavements Design in China, International Conference on Perpetual Pavement Ohio Research Institute for Transportation and the Environment, 2006. 
APÊNDICE A - Gráfico resultante do ensaio reológico dos ligantes A e B na condição virgem

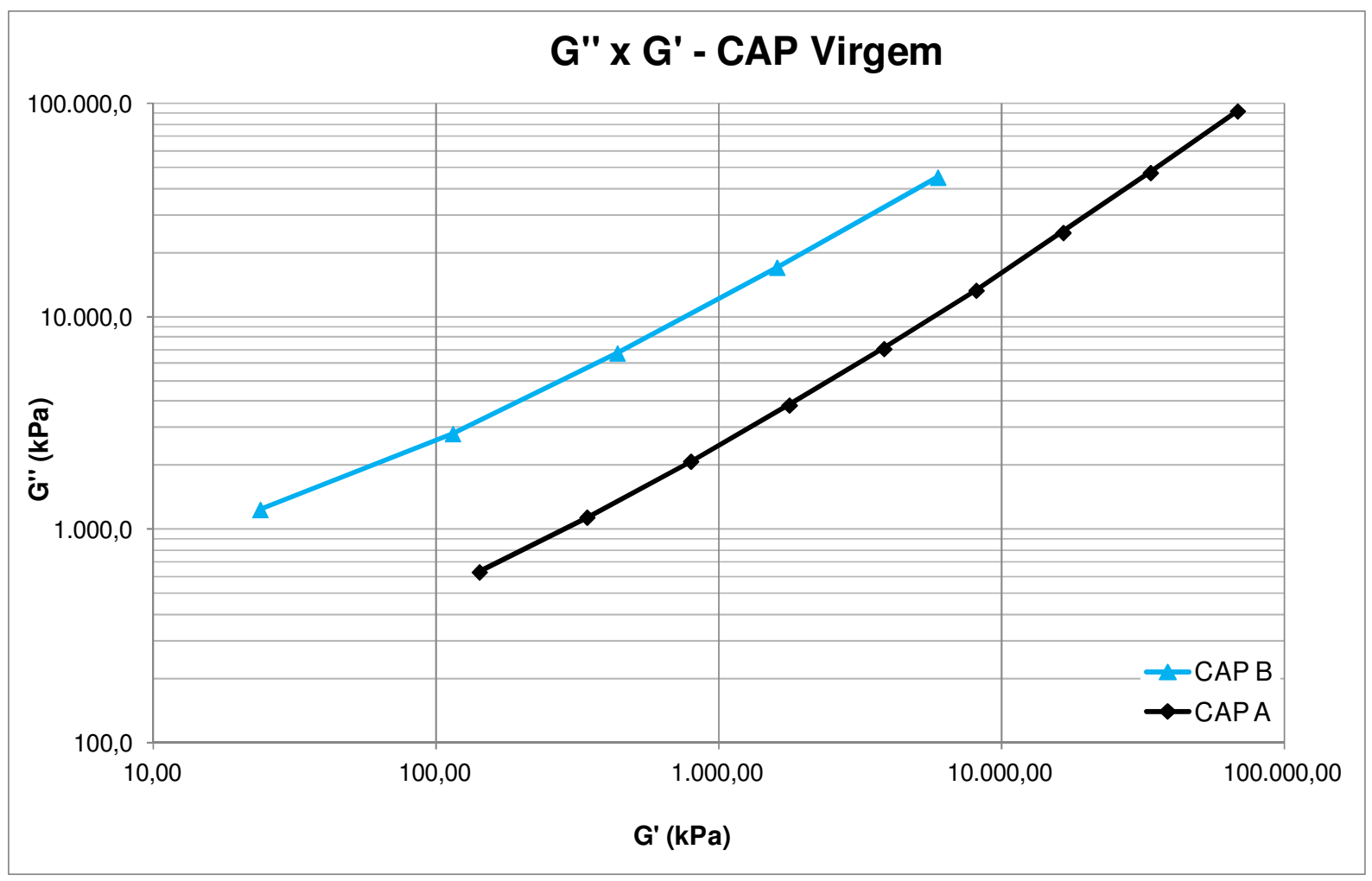




\section{APÊNDICE B - Dosagem Marshall}

CAP A

\begin{tabular}{c|c|c|c|c|c|c|}
\hline \multicolumn{6}{|c}{ GRÁFICOS DOS PARÂMETROS } & DA MISTURA - CAP A \\
\hline$\%$ & Massa Específica & $\%$ & $\%$ & $\%$ & $\begin{array}{c}\text { RESISTÊNCIA } \\
\text { A TRAÇÃO } \\
\text { (RT) (MPa) }\end{array}$ \\
\hline Asfalto & APARENTE & Máx. da Mistura & Va & VAM & VCA & $\mathbf{2 , 4}$ \\
\hline $5,5 \%$ & 2,354 & 2,446 & $3,7 \%$ & $\mathbf{1 5 , 5 \%}$ & $\mathbf{7 5 , 8} \%$ & \\
\hline
\end{tabular}
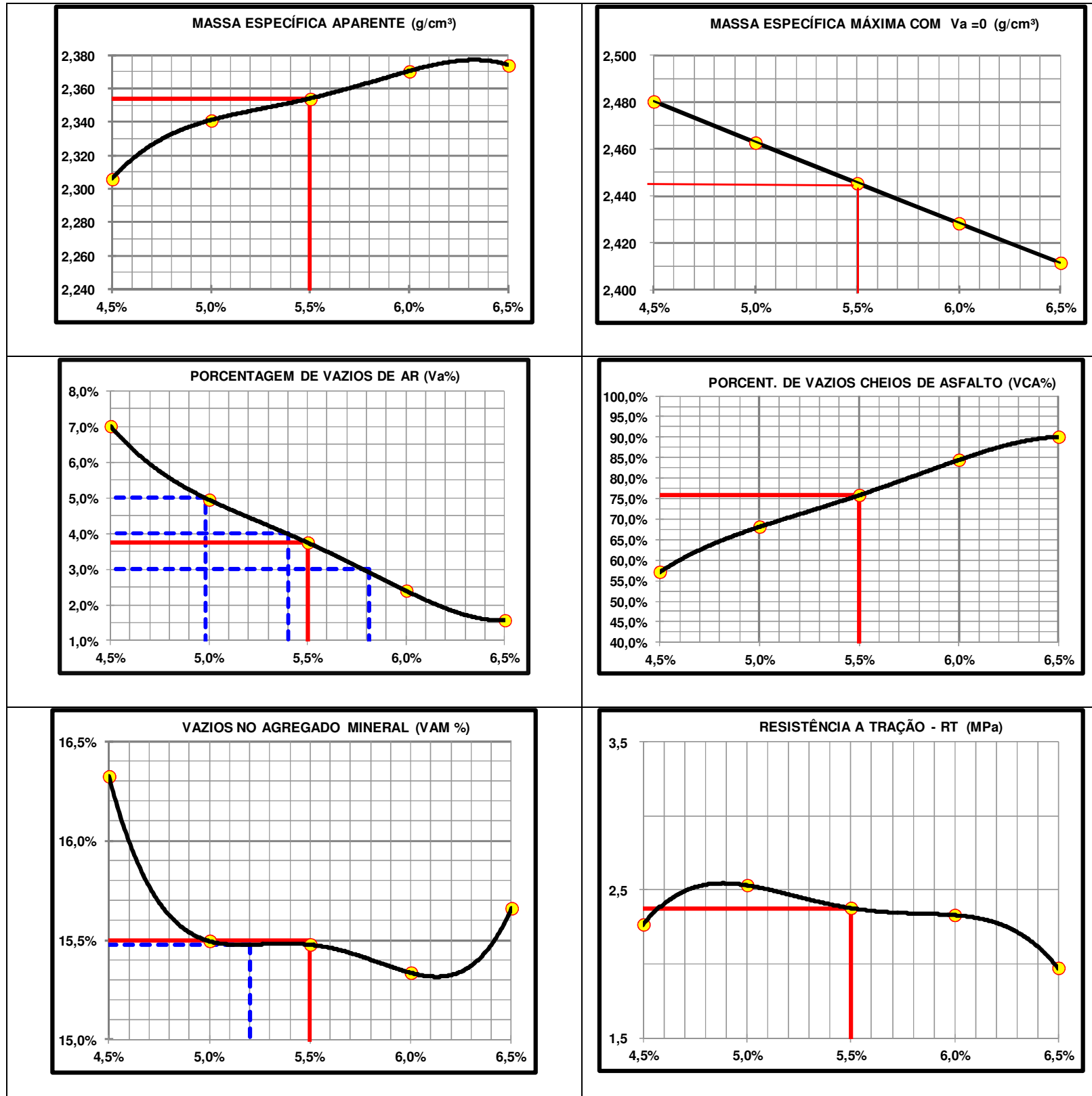
CAP B

\begin{tabular}{c|c|c|c|c|c|c}
\hline \multicolumn{6}{|c}{ GRÁFICOS DOS PARÂMETROS } & DA MISTURA - CAP B \\
\hline$\%$ & \multicolumn{2}{|c|}{ Massa Específica } & $\%$ & $\%$ & $\%$ & $\begin{array}{c}\text { RESISTÊNCIA } \\
\text { A TRAÇÃO } \\
\text { (RT) (MPa) }\end{array}$ \\
\hline Asfalto & APARENTE & Máx. da Mistura & Va & VAM & VCA & $\mathbf{3 , 2}$ \\
\hline $\mathbf{4 , 8} \%$ & $\mathbf{2 , 3 7 2}$ & $\mathbf{2 , 4 6 3}$ & $\mathbf{3 , 7} \%$ & $\mathbf{1 4 , 2} \%$ & $\mathbf{7 3 , 9} \%$ & \\
\hline
\end{tabular}
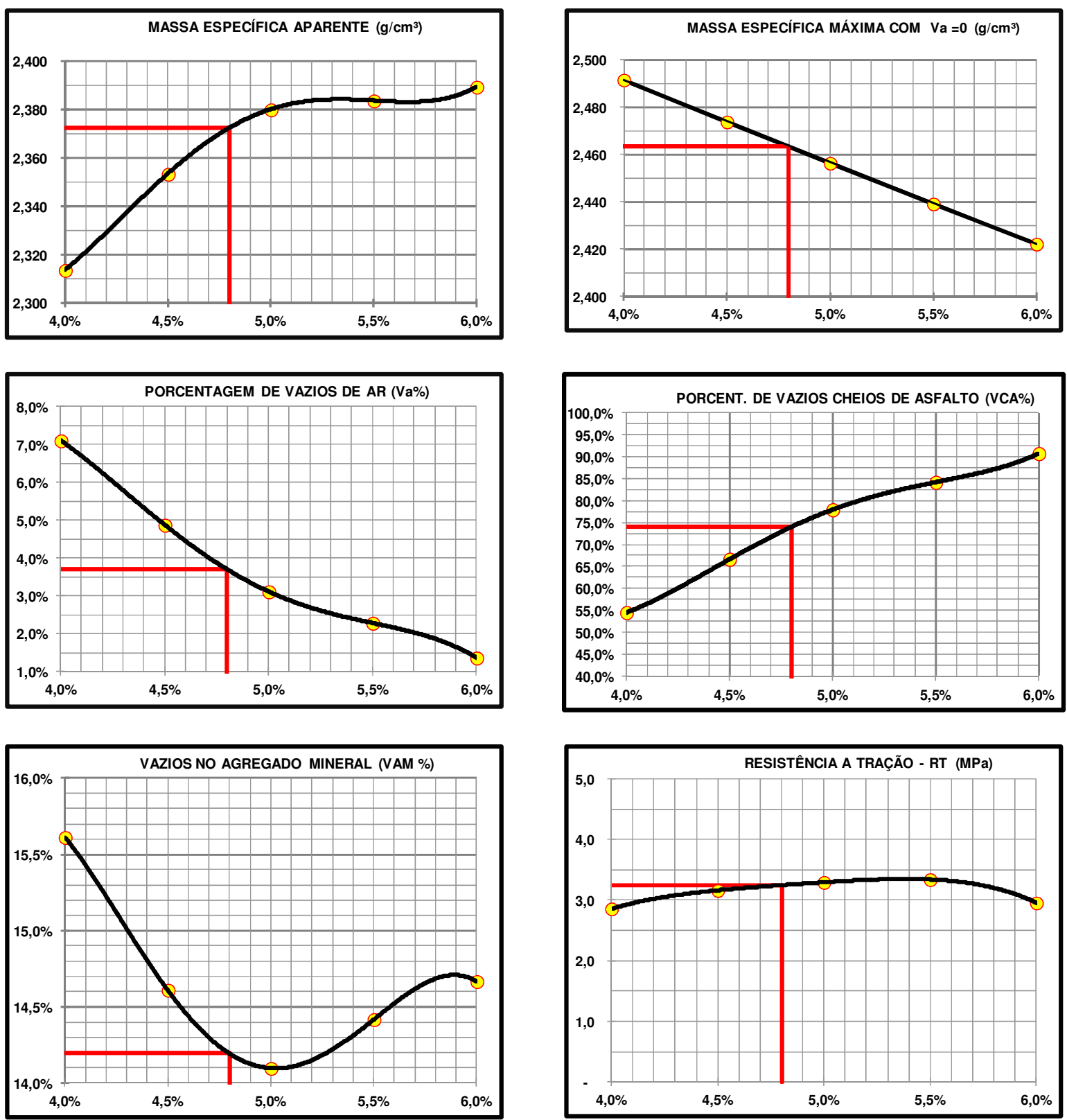
CAP $30 / 45$

\begin{tabular}{|c|c|c|c|c|c|c|}
\hline \multicolumn{7}{|c|}{ GRÁFICOS DOS PARÂMETROS DA MISTURA - CAP 30/45 } \\
\hline$\%$ & \multicolumn{2}{|c|}{ Massa Específica } & $\%$ & $\%$ & $\%$ & RESISTÊNCIA \\
\hline Asfalto & APARENTE & Máx. da Mistura & Va & VAM & VCA & (RT) (MPa) \\
\hline $4,8 \%$ & 2,363 & 2,460 & $4,0 \%$ & $14,5 \%$ & $72,7 \%$ & 2,3 \\
\hline
\end{tabular}
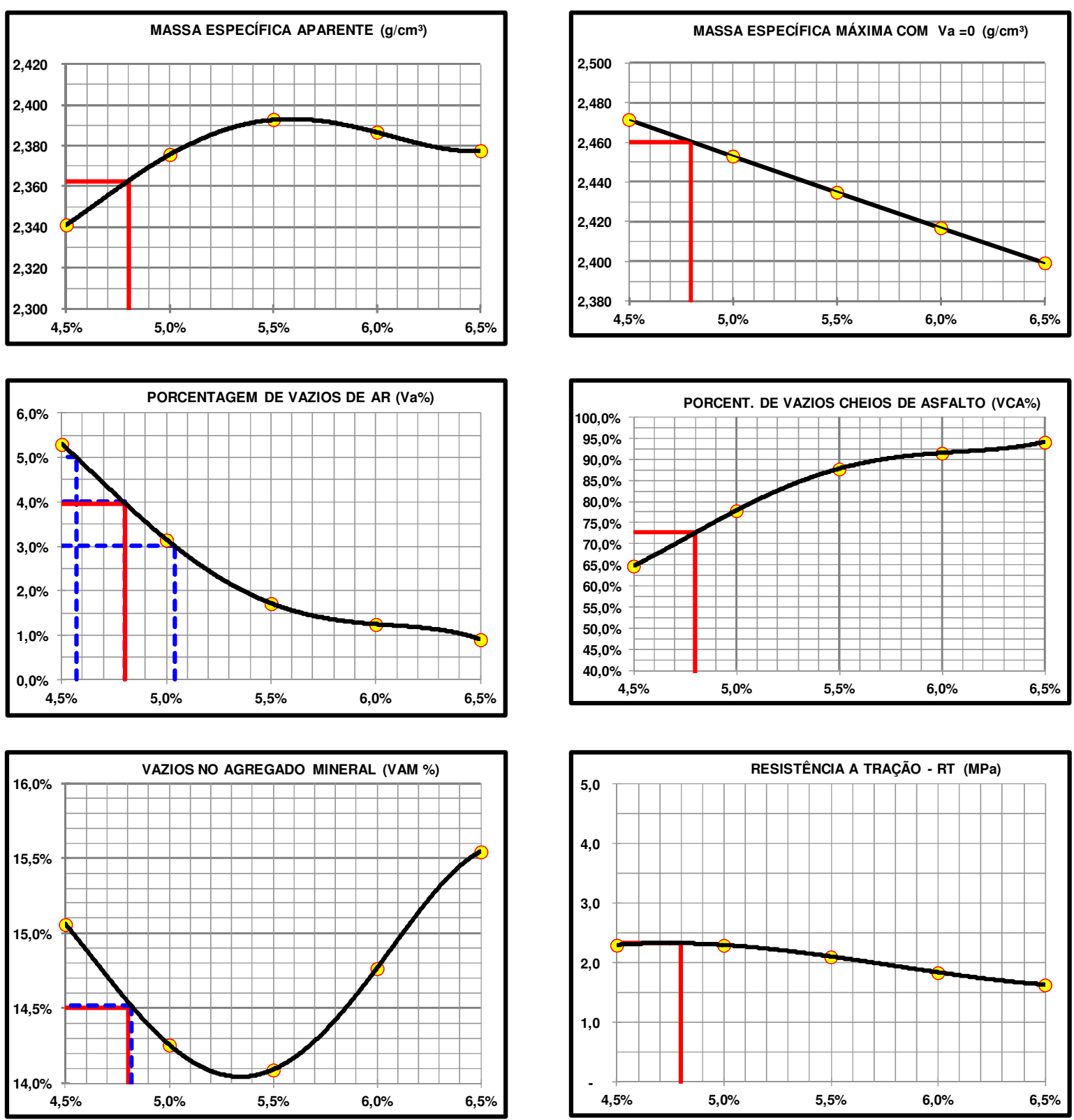
APÊNDICE C - MóduloDinâmico para cada temperatura de ensaio
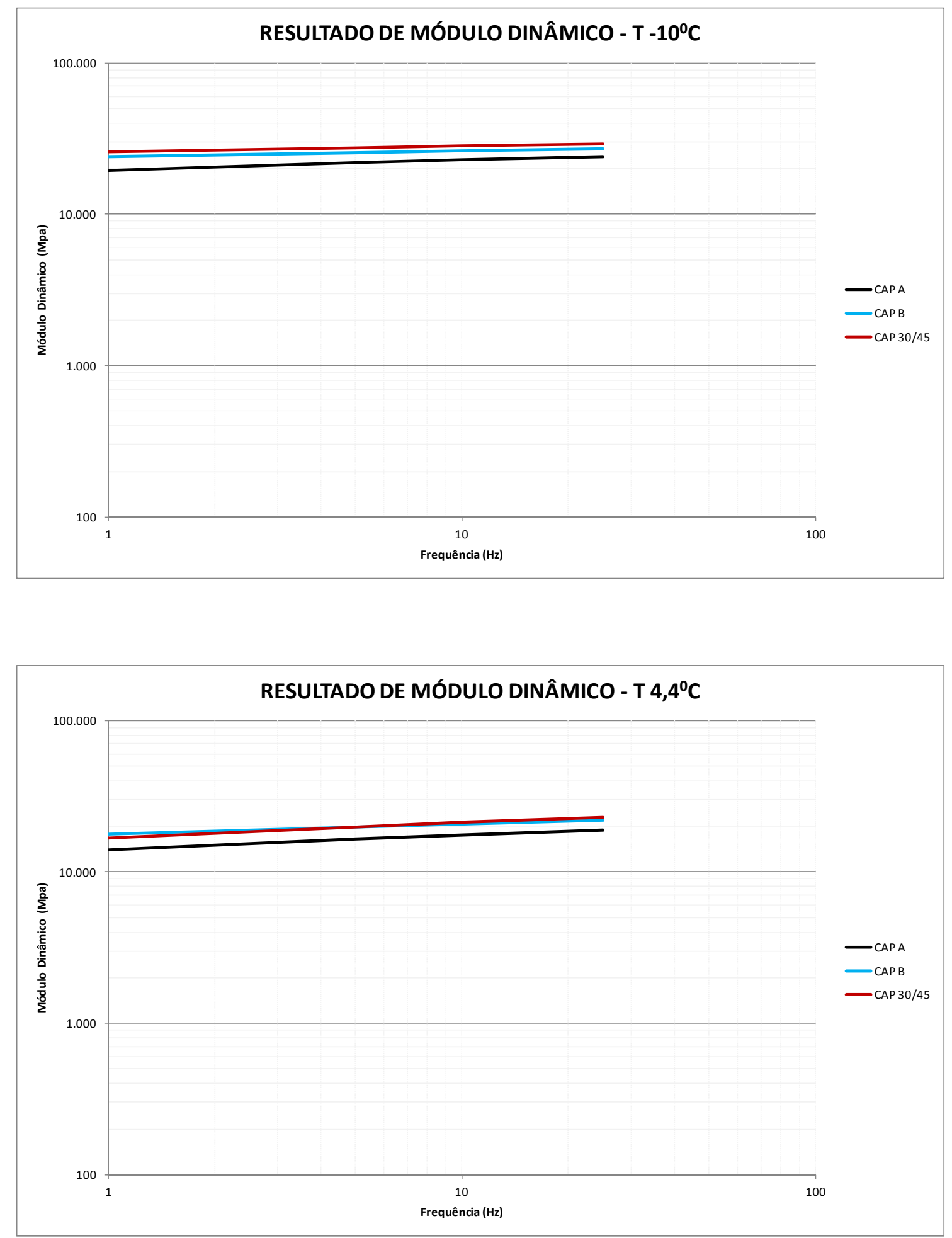

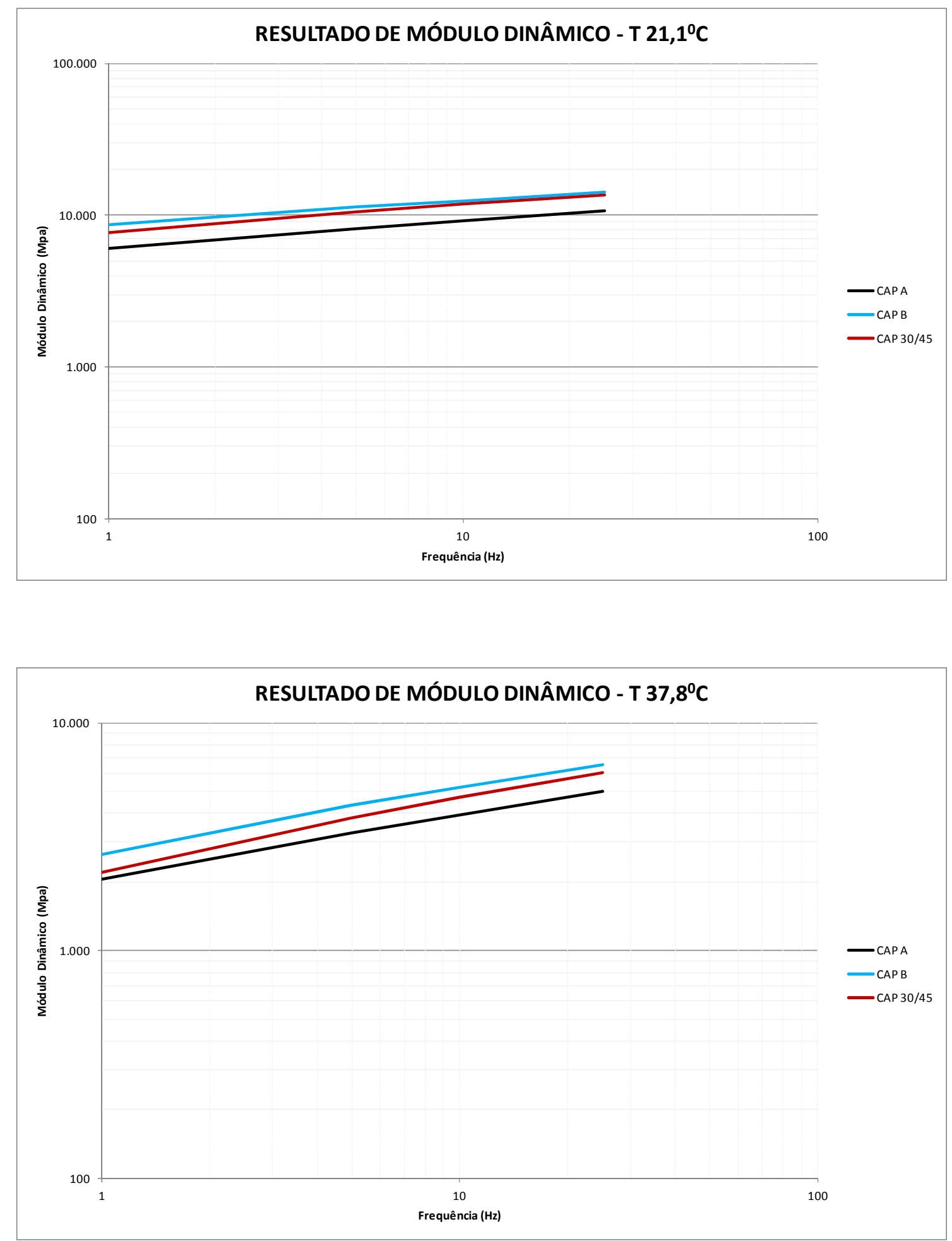


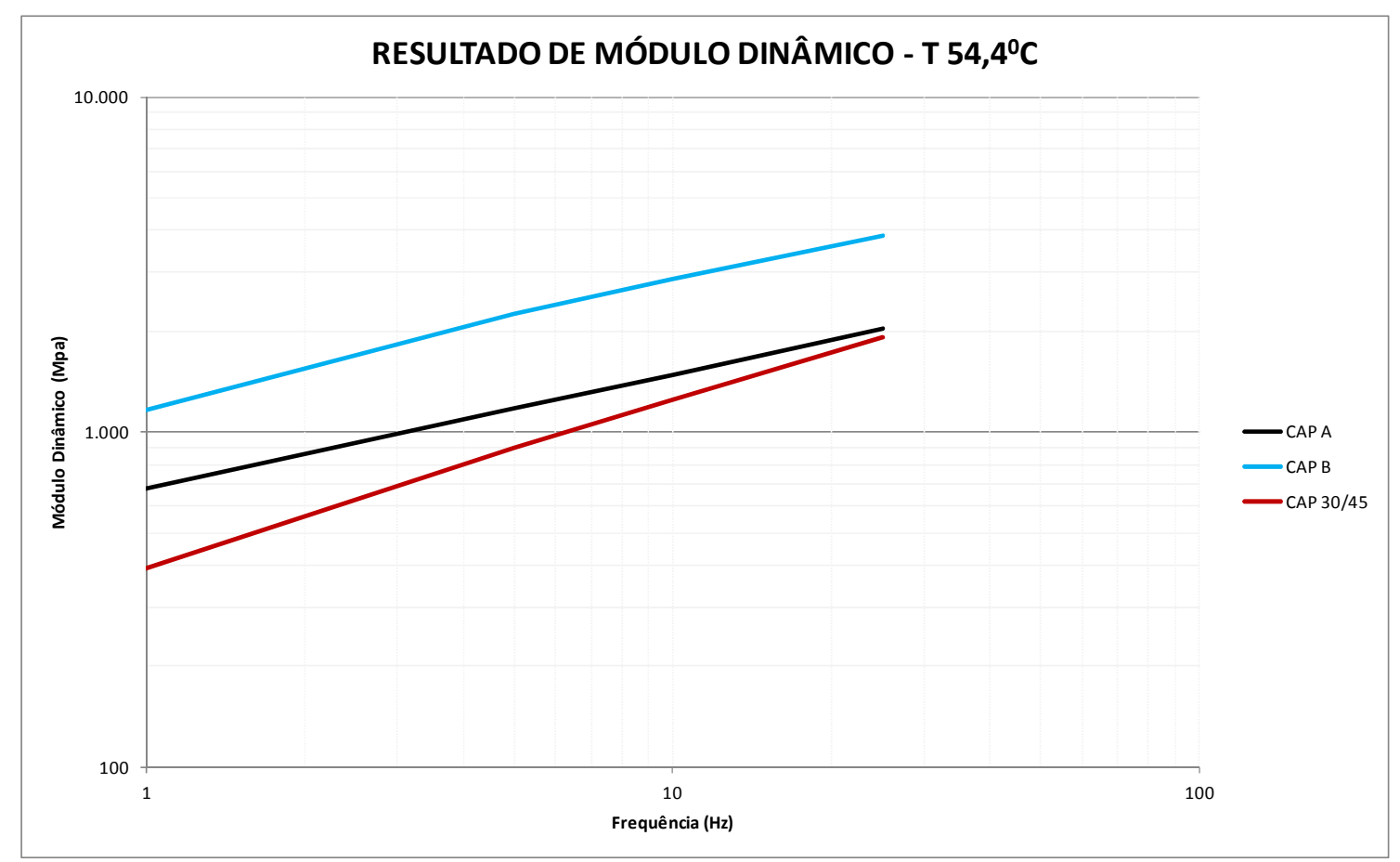


APÊNDICE D - Sequência de ensaios utilizados nesta pesquisa e laboratórios envolvidos

\begin{tabular}{|c|c|c|c|c|}
\hline DESCRIÇÃO & LTP- USP & EESC-USP & CPR- NovaDutra & REFERÊNCIA NORMATIVA \\
\hline \multicolumn{5}{|l|}{ ENSAIOS DE CARACTERIZAÇÃO DO MATERIAL } \\
\hline \multicolumn{5}{|l|}{ AGREGADO } \\
\hline Equivalente de areia & & & $\mathrm{x}$ & NBR- 12052/1992 \\
\hline Índice de Forma & & & $x$ & NBR- 7809/2006 \\
\hline Abrasão Los Angeles & & & $\mathrm{x}$ & NBR NM-51/2001 \\
\hline \multicolumn{5}{|l|}{ LIGANTE } \\
\hline Penetração (100g, 5s,250 C) & & & $x$ & NBR 6576/2007 \\
\hline Ponto de Amolecimento (Anel e Bola) & & & $\mathrm{x}$ & NBR $6560 / 2008$ \\
\hline Viscosidade Brookfield a $135^{\circ} \mathrm{C}$ & & & $\mathrm{x}$ & NBR15184/2004 \\
\hline Viscosidade Brookfield a $150^{\circ} \mathrm{C}$ & & & $x$ & NBR15184/2004 \\
\hline Viscosidade Brookfield a $177^{\circ} \mathrm{C}$ & & & $x$ & NBR15184/2004 \\
\hline PG alta temperatura - ligante virgem & & $\mathrm{x}$ & & ASTM D7175/2008 \\
\hline RTFOT & & $\mathrm{x}$ & & ASTM D2875/2004 \\
\hline MSCR após RTFOT & & $\mathrm{x}$ & & ASTM D7405/2010a \\
\hline \multicolumn{5}{|l|}{ MISTURAS ASFÁLTICAS } \\
\hline Granulometria & & & $\mathrm{x}$ & AASHTO T 209/2005+ Instituto do Asfalto/2002 \\
\hline Dosagem Marshall & $\mathrm{x}$ & & $\mathrm{x}$ & NBR 12891/1993 \\
\hline Dosagem Metodologia Superpave & & & $\mathrm{x}$ & SUPERPAVE FUNDAMENTALS - Reference Manual \\
\hline Dosagem francesa - apenas compactação no teor de projeto (Marshall)- PCG & $\mathrm{x}$ & & & NF P 98 252/1999a \\
\hline DANO POR UMIDADE INDUZIDA & $\mathrm{x}$ & & $x$ & AASHTO 283 e NBR 15617 \\
\hline \multicolumn{5}{|l|}{ ENSAIOS MECÂNICOS } \\
\hline Deformação Permanente (Simulador) & $\mathrm{x}$ & & & NF EN 12697/2008 \\
\hline Resistência a Tração & $\mathrm{x}$ & & $\mathrm{x}$ & NBR 15087/2012 \\
\hline Módulo de Resiliência & $\mathrm{x}$ & & $x$ & ASTM D 7369/2009 \\
\hline Módulo Dinâmico & & & $x$ & ASTM D3497/2003 \\
\hline Fadiga por tração em ensaio de compressão diametral (TENSÃO CONTROLADA) & $\mathrm{x}$ & & & \\
\hline Fadiga por flexão de 4 pontos- vigota (DEFORMAÇÃO CONTROLADA) & & & $\mathrm{x}$ & AASHTO T 321/2003 \\
\hline
\end{tabular}


ANEXO A - Fatores que afetam a rigidez e vida de fadiga de misturas (Ghuslan, 2001)

\begin{tabular}{|c|c|c|c|c|}
\hline \multirow[b]{2}{*}{ Factor } & \multirow[b]{2}{*}{ Change in Factor } & \multicolumn{3}{|c|}{ Effect of Change in Factor } \\
\hline & & On Stiffness & $\begin{array}{l}\text { On Fatigue Life } \\
\text { in C-Stress Test }\end{array}$ & $\begin{array}{l}\text { On Fatigue Life } \\
\text { in C-Strain Test }\end{array}$ \\
\hline Asphalt Viscosity & Increase & Increase & Increase & Decrease \\
\hline Asphalt Content & Increase & Increase : & Increase : & Increase b \\
\hline Agrregate Type & $\begin{array}{l}\text { Increase Roughness } \\
\text { and angularity }\end{array}$ & Increase & Increase & Decrease \\
\hline $\begin{array}{l}\text { Aggregate } \\
\text { Gradation }\end{array}$ & $\begin{array}{l}\text { Open to Dense } \\
\text { Gradation }\end{array}$ & Increase & Increase & Decrease d \\
\hline Air Void Content & Decrease & Increase & Increase & Increase d \\
\hline Temperature & Decrease & Increase : & Increase & Decrease \\
\hline
\end{tabular}

